Universidad Nacional de La Plata

FACULTAD DE HUMANIDADES Y CIENCIAS DE LA EDUCACIÓN

SECRETARÍA DE POSGRADO

\title{
La Medellín de los silleteros: identidad, memorias e imágenes de ciudad
}

Análisis de la memoria oficial de Medellín, Colombia, a través del caso de los silleteros de Santa Elena.

\section{Paula Guisao López}

Tesis para optar por el grado de Magister en Historia y Memoria

Director, Enrique Garguin, Universidad Nacional de La Plata

La Plata, septiembre de 2015 


\section{Resumen}

Esta tesis analiza la memoria oficial de Medellín (Colombia) como una ciudad que pasó de ser la más peligrosa del mundo en los años noventa a convertirse en un ejemplo de transformación e innovación en la última década, a partir del estudio del desfile de silleteros.

Como el evento central de su festividad folclórica más representativa, este caso concreto permite no solo conocer el relato oficialista con el que hoy se mercadea dicha urbe en el mundo, sino también entender los usos políticos y económicos que los gobiernos de turno le han dado para intentar ocultar otras versiones del pasado reciente.

Dichos usos se han valido de elementos tan arraigados como la identidad, que en este caso se convierte en un elemento fundamental para formar esa narración del pasado, partiendo del presente. Así que el silletero se ha convertido en la figura actual más representativa de la cultura paisa, con lo cual se pretende regresar a imágenes y arquetipos del pasado antioqueño, que se lograron instalar en la región con características positivas y excepcionales pertenecientes a una "raza superior" que todavía sirve para justificar discursos, como el de la superación de la violencia en la ciudad.

Así que tras un rastreo, tanto por la formación de esa identidad como de su permanencia en la actualidad, así como por la fundación del desfile de silleteros como tradición, se halla la conexión entre ambos hechos como fundamental para la imagen que los gobiernos y los medios de comunicación han construido de la Medellín de hoy.

Pero a través de ese mismo recorrido también es inevitable que surjan esas otras memorias e imágenes paisas, que nos retornan a la ciudad de los capos del narcotráfico y las víctimas de su guerra, a la ciudad en la que sus familiares reclaman todavía verdad y justicia, a la ciudad en la que miles de extranjeros siguen buscando droga y mujeres como en las épocas de Pablo Escobar, a la ciudad en la que la periferia sigue estando amenazada por el crimen, la desigualdad y la pobreza.

Por eso, este es un esfuerzo por hallar un punto medio entre la excitación de la "nueva Medellín" y su metamorfosis, y la negatividad del estigma que le dejó el narcotráfico. Los silleteros son los guías de este camino, a través de los cuales es posible comprender más allá de ellos mismos y la cultura que el imaginario les ha llevado a representar. 


\section{Índice}

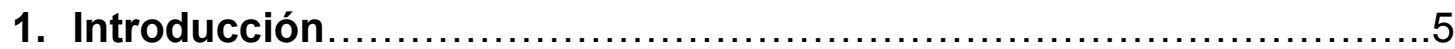

2. La ciudad oficial del Desfile: la metamorfosis de Medellín...............10

2.1. Los planes gubernamentales mercadean la transformación...............11

2.2. La "nueva Medellín" se promociona con los silleteros.....................17

2.2.1. La marca Colombia..................................................... 19

2.2.2. La marca Medellín......................................................24

2.3. Los resultados del mercadeo: el mundo habla de la "nueva

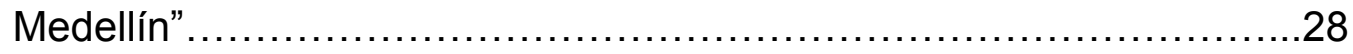

2.4. La "nueva Medellín" y los silleteros en la prensa local....................32

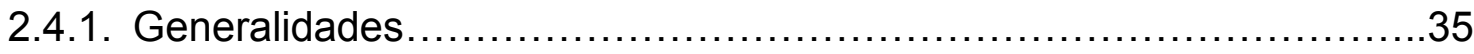

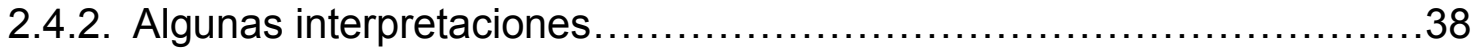

2.5. La ciudad "que pasó del miedo a la esperanza".........................40

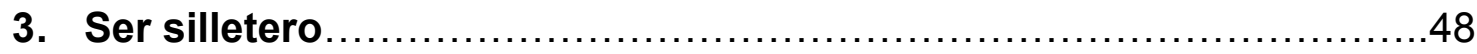

3.1. Tradición heredada................................................. 50

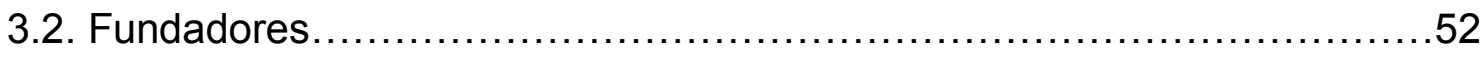

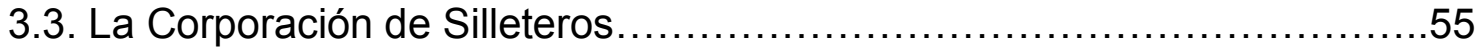

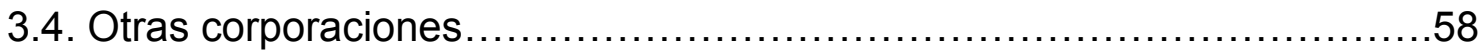

3.5. Así se ven ellos mismos.................................................60

4. Cuando pasa un silletero es Antioquia la que pasa .....................63

4.1. El "proyecto civilizador" de la élite antioqueña...........................65

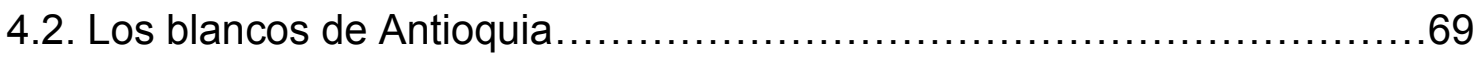

4.3. Los "aventureros" de Antioquia, la bella de piel clara .......................71

4.4. Imágenes paisas antes y después del narcotráfico....................75

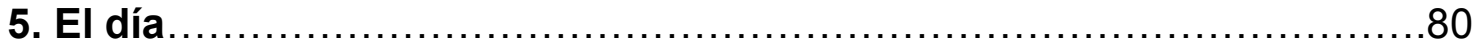

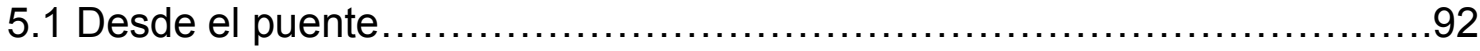




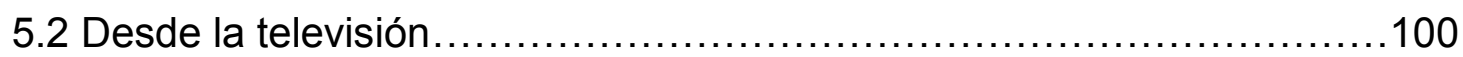

6. La historia de una tradición ........................................110

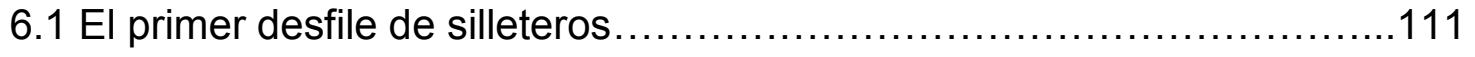

6.2 De cargueros a silleteros................................................. 121

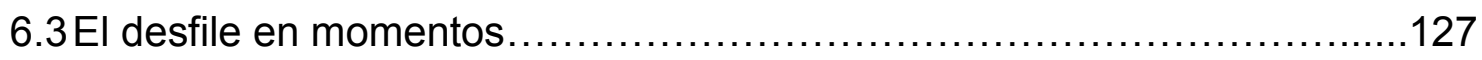

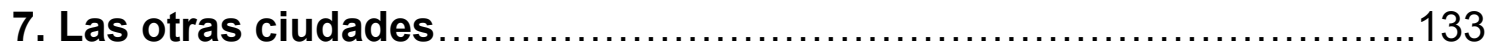

7.1 Los costos de la transformación y los olvidos de la memoria..............135

7.2El turismo no oficial también hace memoria............................139

7.3 ¿La más innovadora, cuna de silleteros y paisas emprendedores, o el "burdel más grande del mundo"? ............................................................148

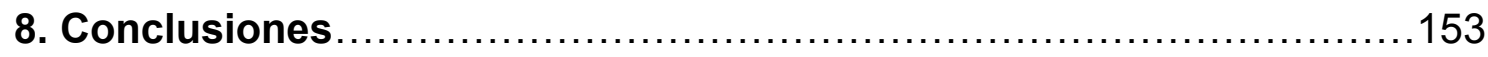

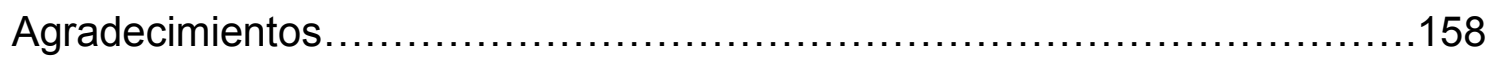

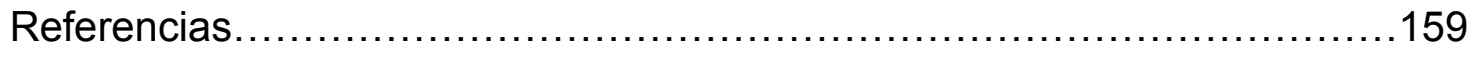




\section{Introducción}

Colombia tiene una gran deuda con las víctimas del narcotráfico. Ya lo dijo Elizabeth Jelin en una de las clases a las que tuve la fortuna de asistir en la Universidad Nacional de La Plata en agosto de 2011, y si bien este trabajo aparentemente está alejado de ellas, en el fondo pretende aportar a ese debate sobre el pasado reciente que ojalá algún día lleve a reivindicar la memoria de todos aquellos que padecieron los difíciles ochenta y noventa en Medellín.

En 2015 la segunda ciudad más poblada de Colombia no es la más violenta del mundo como entonces, pero tampoco la más innovadora como dicen hoy los carteles en sus calles y lo pregona la prensa de todos los niveles. Esos títulos que con dolor y orgullo ha ostentado responden a una mirada pintada de blanco y negro que no tiene en cuenta la paleta de colores en medio, principal preocupación de esta investigación, en la que se parte de un caso concreto para presentar una problemática general referida a la necesidad de abordar el pasado reciente de Medellín con todas sus dificultades.

Es que aunque evidentemente Medellín no es la misma de mi niñez, en la que madres como la mía tenían que salir corriendo de su trabajo porque escucharon en la radio que habían puesto una bomba justo en frente de la guardería de su hija, en la que los noticieros tuvieron que aprender de ética y limitar el sensacionalismo para evitar teñir de rojo las pantallas y los periódicos. Solo hay que sentarse al medio día frente a uno de esos mismos telediarios y comprobar que las noticias han dado un giro radical, y que en la actualidad en vez de violencia y narcotráfico se refieren a Medellín como un ejemplo latinoamericano de innovación y emprendimiento. Pero ¿cómo se logró dicha transformación? Y ¿hasta qué punto es tan real? ¿Qué memoria construyen esos relatos? ¿Qué memorias silencian? Son algunas de las preguntas en las que se basa este trabajo para encontrar la cantidad de puntos grises entre la cara más positiva y la más negativa de la capital antioqueña.

En los últimos años esta ciudad se ha enfrentado a una serie de cambios a nivel social y urbano, reflejados en una modificación de su imagen en el exterior con respecto a décadas anteriores. De ser conocida en el mundo por ser la cuna del narcotráfico colombiano y tener los más altos índices de violencia, pasó a convertirse en un ejemplo de innovación y superación del "terror". Las visitas y la inversión internacional se reactivaron, así como la posibilidad de convertirse en sede de innumerables eventos que superan las fronteras nacionales.

Así se vende desde hace algunos años, cuando las administraciones locales decidieron empezar a invertirle a esa "transformación". Como ha sucedido en muchos otros países durante las transiciones democráticas, el interés gubernamental se volcó hacia la superación del pasado conflictivo con la promoción de una "nueva ciudad", en este caso, una Medellín moderna, tranquila y cosmopolita. 
Son varios los elementos tenidos en cuenta para consolidar esa imagen de ciudad. Aparte de una serie de transformaciones físicas, también ha habido campañas y publicidad para proyectar esa "nueva" Medellín dentro y fuera del país. El turismo ha sido una estrategia fundamental y es en este eje en el que esta investigación pretende entrar. Teniendo en cuenta que uno de los eventos anuales más importantes para este sector es el Desfile de Silleteros y la Feria de las Flores, vale la pena preguntarse si tanto el desfile como la feria se han articulado a ese discurso que pretende crear y proyectar una memoria reciente de ciudad, una memoria que selecciona determinada fracción del pasado y niega y olvida otras.

Por eso, este es un esfuerzo por rastrear esas traumáticas décadas teniendo en cuenta la identidad como elemento fundamental para el relato del pasado, pero también del presente. Así que los inicios de este trabajo pueden hallarse al escarbar en el estereotipo colombiano surgido de las peores épocas del narcotráfico y que desde entonces relaciona al país y a sus nacionales con drogas y violencia, pasando por los arquetipos locales de los que se valieron las élites en el siglo XIX para dividir el país en "regiones" y lograr la supremacía de unas sobre otras, hasta llegar a los referentes propios y la mirada externa de la cultura dentro de la que crecí.

Por eso se hace fundamental explorar el concepto de "paisa" como se le llama a los habitantes de Antioquia y su zona de influencia, los mismos que dentro de esas fragmentación provincial han llegado a considerarse como una "raza superior" durante los siglos XIX y XX, pero que en las últimas décadas también han sido sinónimo de mafioso o tramposo. Una doble definición que surge de esas visiones radicales y con las que todavía hay quien explica determinados fenómenos de la actualidad, de manera que más de uno ha atribuido la transformación de Medellín al "empuje y la verraquera (sinónimo de aguerrido y valiente) paisa".

En este recorrido me encontré con los principales símbolos de la ciudad que hoy se muestra a periodistas y turistas extranjeros, y que son resultado de una búsqueda identitaria de antaño basada en siglos de arquetipos y supuestos, interrumpidos por las épocas oscuras del narcotráfico: los silleteros de Santa Elena se han convertido en los principales representantes de lo paisa y uno de los elementos más significativos para distinguirla de otras culturas en medio del actual mundo globalizado que pretende volver a los orígenes y la tradición.

El desfile inició como un acto de la feria, pero con el tiempo, los silleteros fueron tomando relevancia en el ámbito local, en especial durante el evento, pero también empezaron a tenerse en cuenta como representantes de la "cultura" de la ciudad ante el resto del país e incluso, fuera de él. Así que en el escenario actual de transición que promocionan las autoridades medellinenses, habría que cuestionarse acerca de la posibilidad del uso de la figura del silletero como emisario de ese cambio de ciudad, debido a su carácter emblemático y patrimonial y a las posibilidades del discurso que pueden comunicar, ya sea en su desfile y 
sus silletas (las de tipo emblemático llevan mensajes) o en sus intervenciones públicas, dentro o fuera del país.

El relato popular tradicional propone que los silleteros iniciaron como "cargueros", una especie de transporte humano para mercancía y personas (Gobernación de Antioquia, 2007: 68), el cual es un antecedente presente en varias regiones. Las décadas anteriores al primer desfile, fueron de hombres que usaron las silletas para llevar las flores que cultivaban en Santa Elena para vender en las plazas, iglesias, cementerios y viviendas de Medellín. Ese fue el silletero que inspiró el hoy evento central de la Feria: el que caminaba tres o cuatro horas con una estructura cargada de flores a su espalda. Después llegó el desfile y con él el turismo y el reconocimiento cultural de los silleteros como emblema del país. En la actualidad, métodos modernos como los invernaderos y modelos económicos más rentables como la exportación, dejaron el cultivo a grandes empresas y a los silleteros el papel de artesanos, tal como los denomina Bolívar. Pero si son productores artesanales de flores y también de imágenes, símbolos y memorias, de ¿Qué imágenes? ¿Qué símbolos? ¿Qué memorias? construyen.

Así que es posible volver al desfile de silleteros e ir más allá del carácter generacional que posee la práctica para hablar de tradición. Se trata de una versión selectiva de "un pasado configurativo y de un presente preconfigurado, que resulta poderosamente operativo dentro del proceso de definición e identificación cultural y social" (Williams, 1980, p. 137). El silletero se convierte en esta fiesta en emblema del antioqueño (habitante de esta región), tal como lo propone el lema del desfile "cuando pasa un silletero, es Antioquia la que pasa". Y la historia de esos hombres que cargaban flores desde la zona rural medellinense se convierte en la fracción de pasado que se selecciona, por la que se pretende ser reconocido en Colombia y el mundo.

Justo es lo que sucede con el estereotipo que presentan los silleteros y su desfile, así como el antepasado que representan: parece como si Medellín se hubiese saltado de los años 40 a la primera década del siglo XXI e incluso a mediados del siglo XIX, según las imágenes culturales propuestas. De una urbe incipiente, con campesinos y labores agrícolas, se llega a la ciudad cosmopolita y turística que hoy pretende ser Medellín: ¿será esa la fracción de pasado que se espera quede en la historia, la que fue forjada por unos paisas trabajadores, sacrificados y creativos?

Es el punto en el que empieza el juego de la memoria: selecciona qué recordar, pero también qué olvidar. Recuerda al silletero como descendiente del campesino paisa y olvida al narcotraficante como parte de esa herencia, como pariente directo del medellinense, como él mismo. Ya lo dijeron Tzvetan Todorov (1995), Piere Nora (1993) y María Carman (2006), recordar siempre implica olvidar determinadas fracciones. Así que mientras se activan ciertas narraciones del pasado, es necesario omitir otras. Son claras estás referencias en planteamientos como "inflación de la memoria" de Carman y la "dilatación indiferenciada del campo de lo memorable" para Nora. 
Así que tras tomar el caso del desfile de silleteros de Santa Elena como patrimonio cultural de la nación y evento representativo de la cultura paisa, esta tesis pretende recurrir a su uso dentro de la imagen de la nueva Medellín como una evidencia de la memoria que pretende conservar la ciudad, en contraposición a los olvidos que surgen de dicha selección. De manera que el trabajo se ha dividido en cinco apartados, dedicados a la transformación de la ciudad, la presentación de los silleteros como personajes, su relación con la identidad paisa, la observación de su desfile, su historia como tradición y finalmente las otras ciudades o fragmentos de la memoria que tratan de negarse tras esa metamorfosis urbana que pregonan gobiernos y medios de comunicación.

En la primera parte se hace un contexto general de la transformación de Medellín, teniendo en cuenta la versión oficial dada por los programas de gobierno de los alcaldes de dicho periodo y las estrategias nacionales y departamentales para promover el turismo en el "postconflicto colombiano", pasando por la versión de los medios internacionales que destacan su cambio, en especial después de su primer lugar en el concurso que la declaró "la más innovadora del mundo" y por los medios locales a través de un pequeño estudio cuantitativo y cualitativo sobre el desfile de silleteros en la prensa colombiana y antioqueña, con el fin de hallar nuevamente la conexión entre silleteros y el cambio de percepción de la ciudad.

Una vez evidenciada esta relación, que propone a los silleteros como la cara más amable de la nueva Medellín, se tiene el primer contacto con estos personajes a través de sus testimonios directos y empieza a entenderse quiénes son y cuál es la relación que tienen con la ciudad transformada o más bien con el gobierno de esa urbe que se empeña en destacarlos como la parte más importante de su folclor, y se intuye que por lograr que un día Medellín sea reconocido en el mundo por sus silleteros y no por sus narcotraficantes.

En el siguiente apartado son claves la identidad y la historia antioqueña para comprender un poco la cultura paisa, esa que representan los silleteros y con la que más de uno explica ese tránsito de la Medellín violenta a la Medellín innovadora y segura. Para ello hay que remitirse a investigadores del fenómeno y sus lecturas recomendadas de clásicos locales, así como a momentos coyunturales que ayudaron a forjar dichos arquetipos como la colonización antioqueña, que recurrió a elementos raciales para fortalecer el imaginario identitario del paisa y al mismo tiempo lo usó para justificar la apropiación de tierras y la exclusión de otros grupos étnicos, para finalizar en nuestros días con los discursos propios de los silleteros y la manera en que la opinión pública se refiere a ellos.

La cuarta parte se dedica a observar el desfile, antes y durante su celebración en las principales calles de Medellín, teniendo en cuenta una mirada directa y no participante de la actividad, que inicia con la visita al corregimiento antioqueño en la víspera de la parada y continúa con el desarrollo del evento en sí como espectadora en agosto de 2013, un relato al que se suma el de la transmisión del acto por televisión hecha por los canales regionales, en este caso la realizada en 2012, con el fin de ser más precisa con detalles como el orden del desfile por 
ejemplo, con los cuales es posible tener una visión más amplia de la actividad como ritual.

La historia es otro punto fundamental, gracias al que es posible explorar los inicios de esta práctica que es llamada tradición y que puede explicar parte de esa búsqueda de identidad que tuvieron las élites antioqueñas en algún momento del siglo XIX y que todavía hoy lleva a ciertos estereotipos, y sin adelantarse mucho al contenido de este quinto capítulo, también a la creación de determinados símbolos y eventos a través de los cuales se consolidaron dichas imágenes, a las cuales la "nueva Medellín" recurre hoy para borrar el paso del narcotráfico por su historia.

$\mathrm{Y}$ tras este recorrido por la historia, el contexto, los protagonistas, el territorio, los conflictos y las representaciones mediáticas del desfile de silleteros de Santa Elena volvemos a esa Medellín que introdujimos en el primer capítulo, a esa urbe transformada que se abre paso en el competitivo mundo del turismo y las relaciones internacionales tratando de olvidar su pasado con imágenes positivas como el silletero, pero que aunque logre hacerlo en ocasiones, en muchas otras no puede ignorar esos pasados infames y tiene que enfrentarse a las huellas que la violencia dejó. Por eso este último apartado se remonta a la Medellín del presente y sus versiones alternas a la de la tradición de Santa Elena, es decir a la que los extranjeros que la visitan buscando a Pablo Escobar, su droga y sus mujeres, y en la que todavía hay extorsión, paramilitarismo y casas de tortura.

El análisis de prensa, las entrevistas personales, los documentos oficiales, los informes públicos y las investigaciones previas de estudiosos sobre temas como identidad, cultura paisa y tradición silletera fueron fundamentales para elaborar este texto que parte de una festividad concreta, el desfile de silleteros de Medellín, para tratar de entender un proceso más amplio, la transformación de la ciudad y que por límites de tiempo y espacio deja abiertas un sinnúmero de cuestiones sobre la Medellín de ayer y hoy, y que de alguna manera espera aportar a la construcción de memoria en Colombia. 


\section{La ciudad oficial del Desfile: la metamorfosis de Medellín}

"Que en esta tierra la esperanza siempre vencerá al miedo, por eso cada año Medellín vuelve y nace sin detenerse, se encuentra con su pasado y su futuro, hace de una feria una excusa..." (Myjunglebox, 2011)

"Tradition? Relax. It scents the air when the City of Eternal Spring bursts into mid-summer bloom for the annual Feria de las Flores in August. The 58-year-old flower festival fills the streets with kaleidoscopic color, a winsome testament to Medellín's metamorphosis"

(Baker, 2014)

Este capítulo pretende dar una visión general sobre la "transformación de Medellín" promulgada por los gobiernos locales de los últimos años como una ciudad que pasó de ser el centro principal de operaciones del cartel de la droga liderado por el narcotraficante Pablo Escobar durante finales de la década de los ochenta e inicios de los noventa, a ganar concursos internacionales como la "más innovadora del mundo" y ser recomendada por instituciones y medios internacionales como destino destacado para el turismo y los negocios en América Latina.

Dicho cambio es uno de los puntos de partida de esta investigación, la cual se pregunta por el discurso surgido a través de él y el uso del silletero como emisor de dicho mensaje transformador, con el que se crea una memoria de ciudad que selecciona fracciones del pasado reciente y olvida otras, por eso también busca analizar las diferentes estrategias gubernamentales para consolidar la nueva imagen de Medellín ante el mundo mediante la promoción turística de eventos como la Feria de las Flores, que tiene como principales protagonistas a los silleteros.

Así mismo hará un recorrido por la prensa regional, nacional e internacional para empezar a descubrir la conexión existente entre el desfile de silleteros y la metamorfosis de Medellín. En este punto es importante mencionar la función que cumplen los protagonistas de la Feria de las Flores como parte esencial de la imagen positiva de la ciudad que proyecta dicha transformación. Así que mediante una indagación en la representación mediática, tanto de los silleteros y su cultura, como de la "nueva" Medellín, podrá verse la manera en que estos personajes se convierten en la cara amable de la capital antioqueña y remiten al pasado dorado de los paisas, un tema que se tratará con más profundidad más adelante. 


\subsection{Los planes gubernamentales mercadean la transformación}

Medellín es la segunda ciudad en cantidad de población de Colombia, pues cuenta con 3.731.447 de habitantes en su Área Metropolitana, según las proyecciones para 2014 del Departamento Administrativo Nacional de Estadística (DANE). Como capital del departamento de Antioquia, uno de los más activos económicamente del país ha sido uno de sus núcleos industriales. Pero su nombre empezó a destacarse en los titulares de los medios internacionales por otra razón: como acompañante del cartel del narcotráfico que llevaba su nombre, operaba en su territorio y era liderado por Pablo Escobar, en las épocas en las que la ciudad fue considerada "la más peligrosa del mundo" con un promedio diario de 18.7 homicidios y 6.810 anuales durante 1991, el año que registró la tasa más alta de asesinatos (Franco, 2012, p. 3211). Según el Plan de Desarrollo del actual alcalde de Medellín, Aníbal Gaviria, citando información del Instituto Nacional de Medicina Legal, entre 2000 y 2011 existe una tendencia descendente en el número de homicidios, que pasó de 3.158 a 1.649 , equivalente a una baja del $47.8 \%$ (Alcaldía de Medellín, 2012, p. 39). Aunque esa es una visión global, que no tiene en cuenta los aumentos ocurridos entre 2007 y 2009 , cuando se interrumpió esta caída con incrementos del $34 \%$ en el periodo $2007-2008$ y mayor al $100 \%$ en $2008-2009$. Desde entonces se ha vuelto a la baja, con reducciones de 25\% en 2011-2012 y $27 \%$ en 2012-2013, ubicándose en 38.22 por cien mil habitantes, es decir de 920 muertes violentas (Medellín Cómo Vamos, 2014, p. 76).

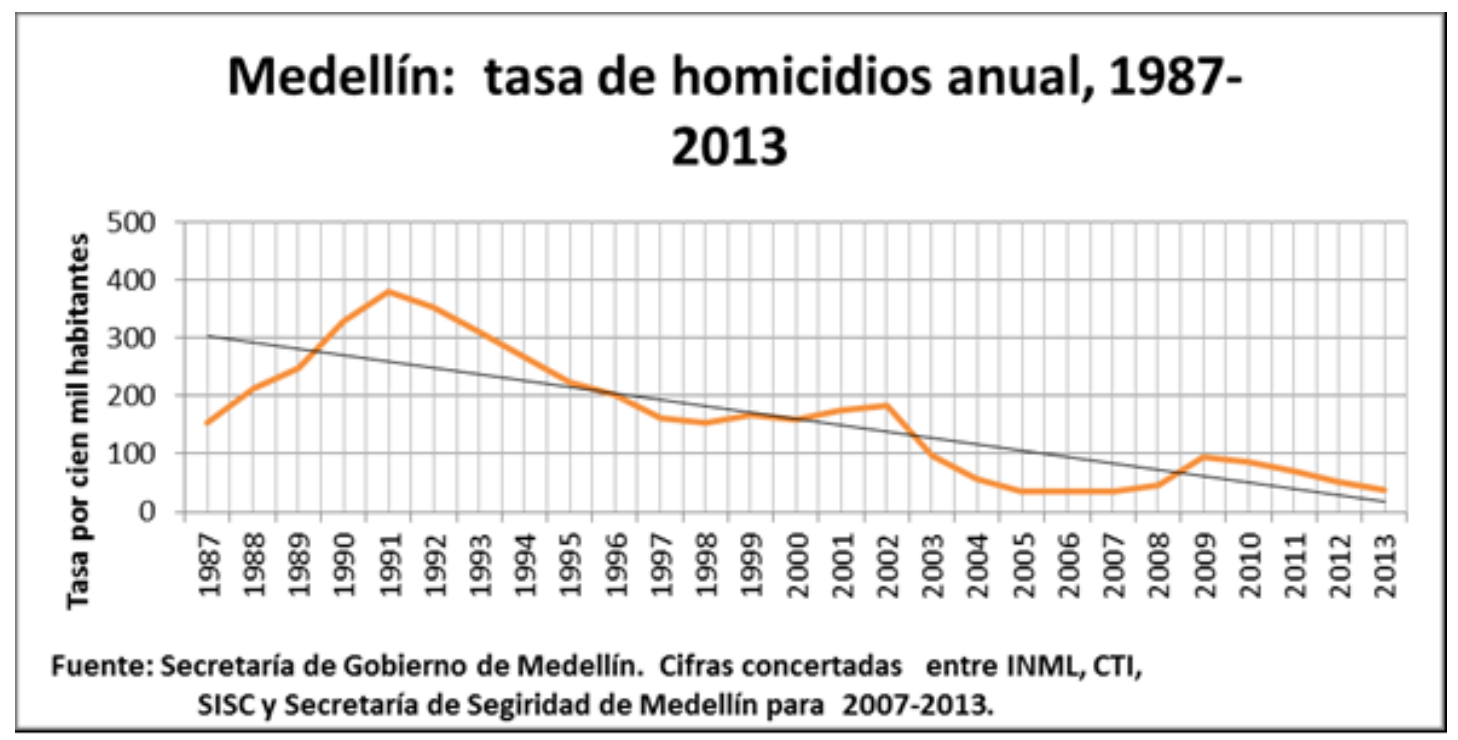

Informe de Calidad de Vida 2013 Medellín Cómo Vamos 
Fuente: Medellín Cómo Vamos, 2013.

Estos son los primeros indicadores que permiten hablar de un cambio, que son explicados por expertos como un resultado de las políticas regionales acumuladas durante 20 años, su aprehensión a las nacionales y el énfasis de los gobiernos de Sergio Fajardo (2004-2007) y Alonso Salazar (2008-2011) en la institucionalidad local (Giraldo, 2008). A este punto deben sumarse otros factores de tipo urbanístico y social:

"Los elementos transversales en la Transformación de Medellín, fueron: 1) el criterio de priorización de la inversión para la intervención social basada en información sobre mediciones y estadísticas relacionadas con la Calidad de Vida (ICV) y el Desarrollo Humano (IDH), lo cual fortalece el proceso de planeación estratégica sobre los territorios, 2) los principios de la gestión pública basados en la transparencia de las finanzas públicas y la transparencia en la contratación, como condición para la generación de la confianza de la ciudadanía hacia el gobierno municipal, 3) la participación de los demás sectores de la sociedad y la construcción de ciudad como compromiso de toda la ciudadanía y 4) la integralidad de la intervención a través de las proyectos urbanos desarrollados" (Mejía, 2013, p. 13).

Este último punto es tal vez uno de los más llamativos porque tiene que ver con un cambio de imagen físico en la ciudad: los proyectos urbanos integrales intervinieron zonas tradicionalmente marginales de la ciudad y permitieron recuperar el espacio público, mejorar las viviendas y el transporte; los parque biblioteca ( 9 en la actualidad), ubicados también en los barrios más necesitados de Medellín, se convirtieron en espacios educativos, administrativos y de sano esparcimiento; y otras construcciones como el Parque Explora, el Parque de los Deseos y la renovación del Jardín Botánico y el Parque Norte, situados en el llamado "nuevo norte" de la ciudad, hoy son zonas renovadas para locales y turistas.

En este ámbito no puede olvidarse la movilidad, mejorada con los metrocables, que gracias a un sistema de teleféricos usados como transporte público conectan los barrios periféricos con el centro, así como las escaleras eléctricas de la Comuna 13 que han hecho más eficientes los traslados en una de las zonas más afectadas por la violencia en la ciudad.

La opinión pública reconoce que la mayoría de estos cambios empezaron a gestarse en la administración de Fajardo y que fueron posibles gracias a la 
continuidad que le dieron las alcaldías posteriores, en especial la de Alonso Salazar que pertenecía a su mismo movimiento político.

A partir de entonces el "modelo Medellín", como empezó a llamársele, es expuesto en congresos internacionales, reseñado en medios de diferentes países, estudiado por expertos de todo el mundo, al tiempo que la ciudad es visitada por estudiantes, peritos y periodistas que quieren ver de cerca la transformación, por gobernantes que quieren replicarlo en sus ciudades y por turistas que ya no tienen miedo y se dejan seducir por el clima, la cultura y demás atractivos que ofrece la capital antioqueña.

Lo anterior no es más que una breve síntesis de lo que puede deducirse al leer algunos artículos académicos y hacer un rastreo sobre lo que la prensa extranjera piensa hoy de Medellín. Lo que no dicen todavía ninguno de ellos es que también existió toda una estrategia gubernamental, en cierto modo publicitaria, para que el mundo conociera esa transformación y para comprobarlo solo hay que observar los planes de gobierno de las tres últimas administraciones.

Los fundamentos del Plan de Desarrollo de Sergio Fajardo inician con un diagnóstico de la ciudad denominado Medellín hoy - la ciudad que queremos transformar, un punto en el que quedan claras las intenciones de la administración y el posterior léxico de "cambio" adoptado tras su ejecución. Una de sus líneas de trabajo fue "Medellín integrada con la región y con el mundo" y puede decirse que fue el punto de partida para lograr el reconocimiento de la "nueva ciudad" que se empezó a gestar bajo su administración.

"El desarrollo de Medellín es, en la actualidad, un hecho que se encuentra íntimamente ligado al devenir de la región, el país y el mundo. Avanzar en este proceso exige que la Administración asuma el liderazgo y promoción de un proyecto de internacionalización compartido a nivel municipal y regional, basado en la articulación interna y externa de procesos económicos, sociales, políticos y culturales" (Alcaldía de Medellín, 2004, p. 144). 


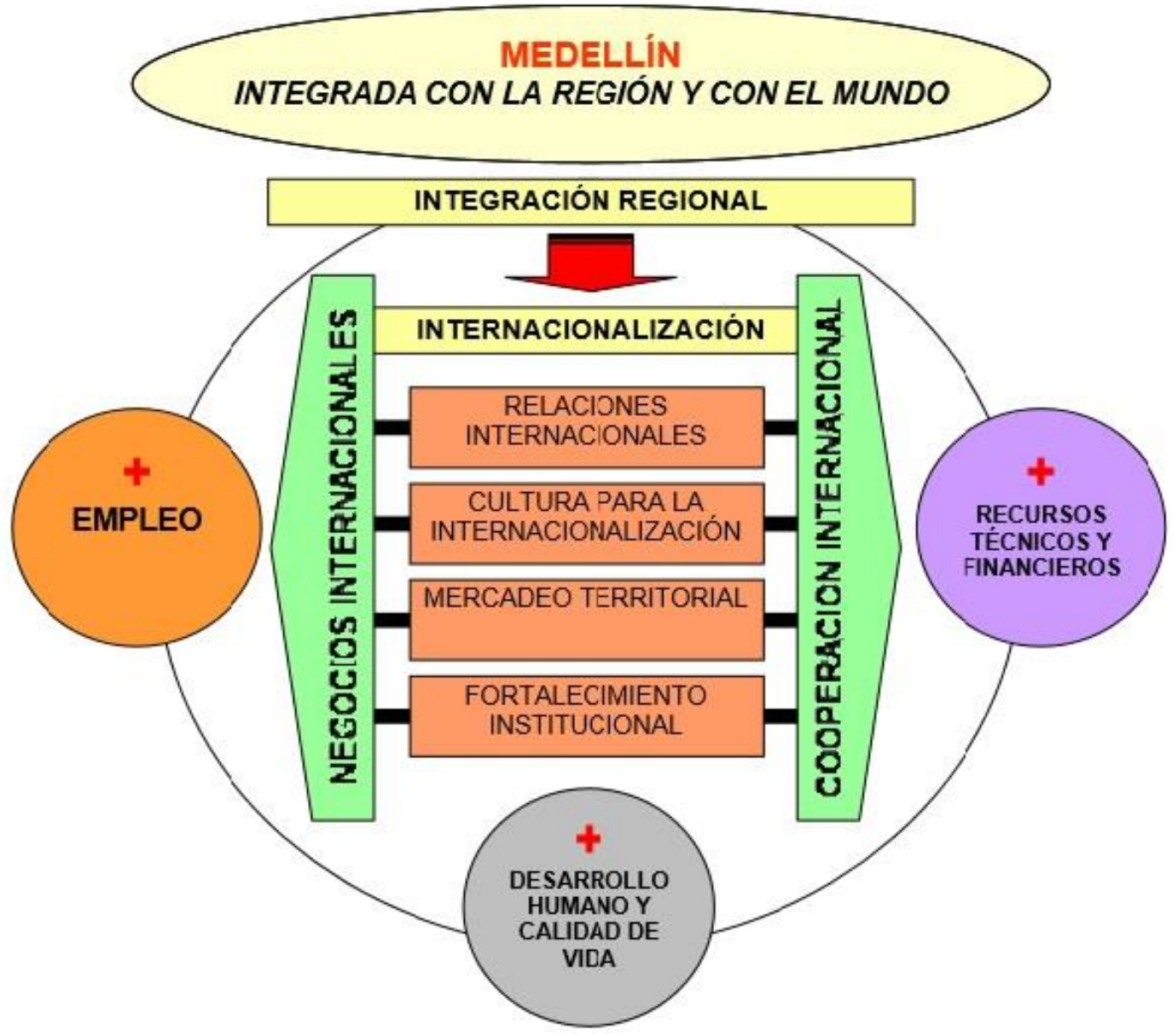

Fuente: Alcaldía de Medellín, 2004.

Este apartado agrega que "mediante la internacionalización se busca que la región, interviniendo sobre su territorio, instituciones y cultura, profundice su participación en los flujos globales de capitales, productos, servicios, cooperación, conocimiento y relaciones multiculturales, acelerando así la obtención de sus objetivos en materia de desarrollo" (Alcaldía de Medellín, 2004, p. 144). 


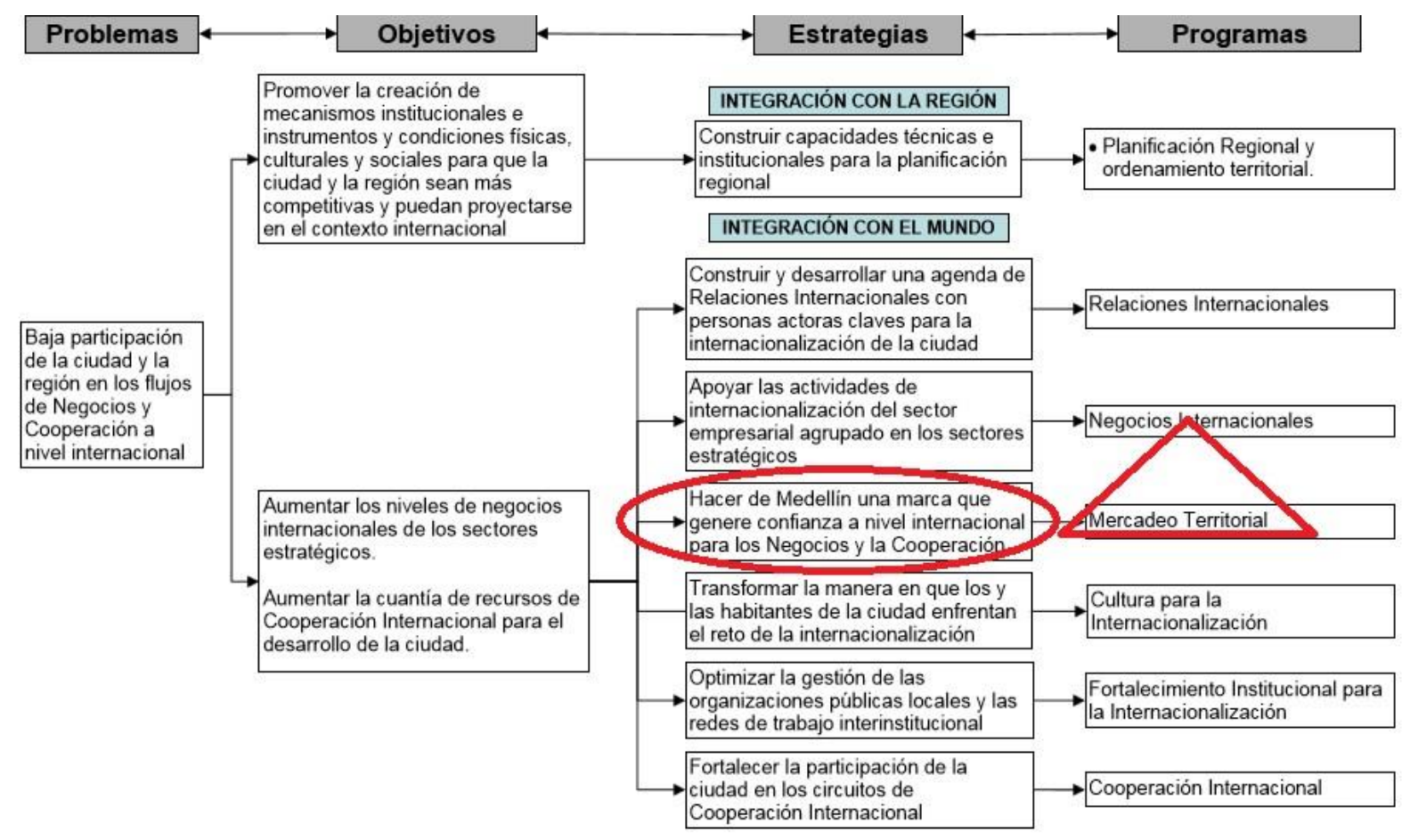

Fuente: Alcaldía de Medellín, 2004

La ilustración anterior resume los puntos que motivan y permitirán desarrollar la línea de internacionalización e integración al mundo del programa de Fajardo. Y en él hay dos aspectos que llaman la atención: la estrategia de "hacer de Medellín una marca que genere confianza a nivel internacional para el desarrollo de actividades de Negocios y Cooperación a nivel internacional" y el programa elegido para lograrlo, que se refiere a "mercadeo territorial", que tenía como meta elaborar un plan de mercadeo responsabilidad de la secretaría de Cultura Ciudadana y el Medellín Convention Bureau.

Los siguientes planes de desarrollo confirman esta estrategia, pues la quinta línea del documento de la Alcaldía de Alonso Salazar tiene como objetivo

"Hacer de Medellín una ciudad con perspectiva de desarrollo regional sostenible, a partir de una concepción de Antioquia como región de ciudades y gestionando articulada y responsablemente el desarrollo integrado de la región, mejorando sus niveles de competitividad y conectividad con el país y el mundo, y el reconocimiento nacional e internacional de sus potenciales de inversión como

\footnotetext{
${ }^{1}$ Resaltado propio.
} 
destino turístico cultural, de centro de negocios y de recepción de cooperación internacional" (Alcaldía de Medellín, 2008, p. 120).

El texto hace énfasis en que la ciudad se convierta en destino de eventos y turismo a través de los esfuerzos gubernamentales y el sector privado e insiste en que "Medellín hoy es un referente indiscutible para la comunidad internacional" y que para entonces ya cuenta con un ambiente de inversión "creado a partir de la transformación de la ciudad" (Alcaldía de Medellín, 2008, p. 116), lo cual pretenden demostrar mediante la realización de eventos como la Asamblea de Gobernadores del Banco Interamericano de Desarrollo BID (marzo de 2009), de manera que resalta la necesidad de continuar haciendo este tipo de ferias, así como diferentes eventos de ciudad, dentro de los cuales la Feria de las Flores es uno de los más importantes.

"Seguiremos haciendo un esfuerzo grande para la llegada de diferentes actores internacionales (periodistas, legitimadores) que sirvan de eco en el mundo de la transformación vivida por Medellín" (Alcaldía de Medellín, 2008, p. 116).

Si Alonso Salazar reconoce el cambio, pero insiste en que el reconocimiento aún es incipiente, Aníbal Gaviría lo asume como una transformación conocida y positiva para la ciudad, por lo que se dedica a continuar el proceso de "mercadearse ante el mundo como una ciudad transformada en lo social y en lo urbano-rural, lo que le ha sumado de manera positiva a los grandes retos de ciudad en su proceso de globalización" a través de una agenda concreta de relaciones internacionales y atracción de grandes eventos de ciudad (Alcaldía de Medellín, 2012, p. 119).

También agrega que la ciudad ha avanzado en visibilidad como posible destino de inversión y ciudad de negocios, sede de grandes eventos, destino de turismo cultural, de naturaleza, de educación y de salud (Alcaldía de Medellín, 2012, p. 120) y agrega cifras concretas: tuvo un incremento del $25 \%$ de visitantes extranjeros entre 2009 y 2010 , ubicando a la ciudad como segundo destino en Colombia con una participación del $13,0 \%$ en el total nacional, es invitada a un promedio de 45 certámenes anuales en todo el mundo y ha ganado cuatro premios anuales por sus buenas prácticas.

Por eso, siguiendo el ejemplo de sus predecesores la línea tres de su Plan se llama "Competitividad para el desarrollo económico con equidad" y tiene el componente "Medellín ciudad conectada con el mundo" que tiene como uno de sus principales programas la "Promoción de Medellín ante el mundo", con la que se busca "lograr un mayor reconocimiento de la ciudad en los ámbitos regional, 
nacional e internacional como destino de turismo, negocios y cooperación internacional" a través de la implementación de "estrategias de mercadeo de ciudad que incrementen su reconocimiento nacional e internacional". Para eso se tienen metas específicas como publicar 200 free press positivos de la ciudad en el mundo entre 2012 y 2015 (la línea base son 94 publicados hasta 2011) y subir una posición en el raking IICA (International Congress \& Convention Asociation) del número 15 al 14 , una de las clasificaciones de ciudades más influyentes en el mundo para elegir los destinos de reuniones de negocios.

Es evidente entonces cómo a partir de la administración Fajardo iniciaron una serie de acciones desde la oficialidad para reivindicar a la ciudad como atractivo turístico latinoamericano, con una clara vocación para los negocios en América Latina y con la promoción de ferias, incluyendo la de las Flores como enfoque fundamental, propuestas que son muy importantes para formar la nueva imagen de ciudad, hoy consolidada dentro y fuera del país y que evidencia el interés y la habilidad de estos gobiernos para re-dirigir la globalización, pasando de una imagen negativa producto de las acciones del narcotráfico que la convirtieron en la más violenta del mundo, a un ejemplo de transformación.

\subsection{La "nueva Medellín" se promociona con los silleteros}

En este apartado se hará referencia a la ejecución de las principales estrategias usadas para promover la ciudad y la Feria, nacional e internacionalmente. Se empezará con los portales oficiales, que funcionan como elementos de información permanentes para locales y foráneos, se continuará con los vídeos oficiales de la Feria -principales piezas publicitarias del evento- y con una serie de folletos y campañas usadas en certámenes internacionales para promocionar a Medellín. El elemento común es la presencia del silletero como símbolo de una ciudad que logró renacer tras décadas de dificultades causadas por el narcotráfico y la violencia.

La primera búsqueda es en la página oficial de la Alcaldía de Medellín (http://www.medellin.gov.co/), en la cual se encuentra un apartado especial para visitantes, del cual se despliega un menú en el que se pueden leer las siguientes opciones: "quiero conocer y visitar a Medellín", "quiero estudiar en Medellín", "quiero hacer negocios en Medellín" y "quiero vivir en Medellín". A este trabajo le interesa especialmente el primer apartado, en el que se puede encontrar una descripción de la ciudad apoyada en la transformación de la que hablan las autoridades locales, objeto de investigación de esta tesis:

"Medellín, ciudad de transformaciones que pasó del miedo a la esperanza invita al disfrute en todos sus rincones, en la que su gente y su infraestructura cambian 
para convertirse en oportunidades de deleite que se logran con los ojos bien abiertos en esta ciudad que le saluda y acoge" (www.medellin.gov.co).

No existe más información al respecto en este sitio, pero se sugiere un direccionamiento a www.medellin.travel, una página también gubernamental que funciona como el portal de promoción de la ciudad para el exterior y en la que puede verse al silletero y la Feria como distintivo de la ciudad "que pasó del miedo a la esperanza" como elementos destacados. La sección ¿Qué hacer en Medellín? resalta la Feria de las Flores como la principal dentro del apartado Ferias y la fotografía de un silletero es usada como fondo de la sección "Medellín, destino de grandes eventos", solo un par de detalles con los que se puede empezar a pensar sobre la cuestión principal de esta investigación.

Si Medellín es un "destino de grandes eventos" y su principal feria es la de las Flores, donde los silleteros son los personajes principales, es necesario indagar en la vinculación entre el tan mencionado cambio de imagen de la ciudad y estos personajes que evocan los inicios de la "cultura paisa".

Solo hay que ver de manera detenida los vídeos promocionales de las últimas cuatro Ferias y la manera en la que se publicita la ciudad: tal vez el más llamativo es el de 2011 que empieza diciendo "cuando llegamos no había nada" y continúa con "trazamos nuevos retos, abrimos nuevos caminos con valentía", claras alusiones a la denominada cultura paisa, que en medio de imágenes de silleteros y flores en paisajes que pueden identificarse como Santa Elena, alude a estos personajes como emblema de la ciudad e incluso del país:

"Nos hicimos símbolo de un pueblo, nos convertimos en tradición de un país, por eso somos historia, somos raza, somos fiesta, niños felices bajo el sol, paisas orgullosos de su gente", dice el narrador para continuar con una referencia al cambio de la capital antioqueña, "que en esta tierra la esperanza siempre vencerá al miedo, por eso cada año Medellín vuelve y nace sin detenerse, se encuentra con su pasado y su futuro, hace de una feria una excusa".

Si vamos a los videos de 2012 y 2013, que tienen la misma canción, queda muy claro que la feria es una "fiesta paisa", "cuando pasa un silletero es Antioquia la que pasa" y "cuando pasa un silletero se emociona el corazón".

Mientras que durante la última fiesta, en 2014, se resalta que "hemos cambiado colores por besos, sabemos renacer, buscamos la respuesta" como una afirmación a la Medellín que superó el pasado traumático de la violencia y que es "tierra de esperanza" porque "somos un pueblo color campesino" donde "la pujanza se dice destino, aquí presente se dice futuro". 
De manera fragmentaria también hay otras frases que pueden interpretarse en el sentido silletero-paisa que hoy ha dejado atrás las difíciles épocas del narcotráfico y la violencia para dar paso a mejores tiempos, "una ciudad que ha olvidado el olvido" y "mi gente siembra progreso".

\subsubsection{La marca Colombia}

La transformación de Medellín va de la mano de un cambio nacional, que se viene gestando gracias a la situación política y la sensación de estabilidad que empieza a tener el país apoyada en diferentes campañas publicitarias que pretenden no solo renovar la imagen internacional de Colombia, sino también atraer inversión y turismo extranjero, de manera que la promoción local de la capital antioqueña no puede desligarse de la construcción de una marca país.

Por eso, en este apartado se hará un breve recorrido por las campañas publicitarias con las que empezó a venderse Colombia en el extranjero a partir del 2005, con el ánimo de ver la manera en que Medellín aparece dentro de ellas y la forma en la que la ciudad hace sus gestiones locales y crea su propia marca para competir internacionalmente.

"Algunos países padecen problemas de imagen, pero no tienen una idea clara de cómo abordarlos. La marca país puede dar la solución a estos problemas. La marca país significa gestionar la imagen y el prestigio de un país" (Dinnie, 2008, p. 3 en Echeverri, Rosker, \& Restrepo, 2010)".

En este contexto es lanzada "Colombia es pasión" en agosto de 2005, con el objetivo de posicionar y consolidar una imagen positiva del país y potenciar otros sectores económicos atrayentes además del café, tras un diagnostico en el que se habían hallado dos percepciones sobre el país en el extranjero: narcotráfico y Juan Valdez (Echeverri, Rosker \& Restrepo 2010).

Echeverri, Rosker \& Restrepo (2010) hacen una dura crítica a la manera en que se gestionó dicha marca, pues creen que se "se desvirtuó hacia el desarrollo de múltiples actividades orientadas a las ventas de una campaña publicitaria en el ámbito nacional en lugar de focalizarse en una gestión de marca" (p. 409), pero por tratarse de una problemática ajena a esta investigación no se profundizará en el tema sino que se tomará como el antecedente del mercadeo de país y de ciudad que iniciaron a partir de entonces para Colombia y Medellín especialmente. 

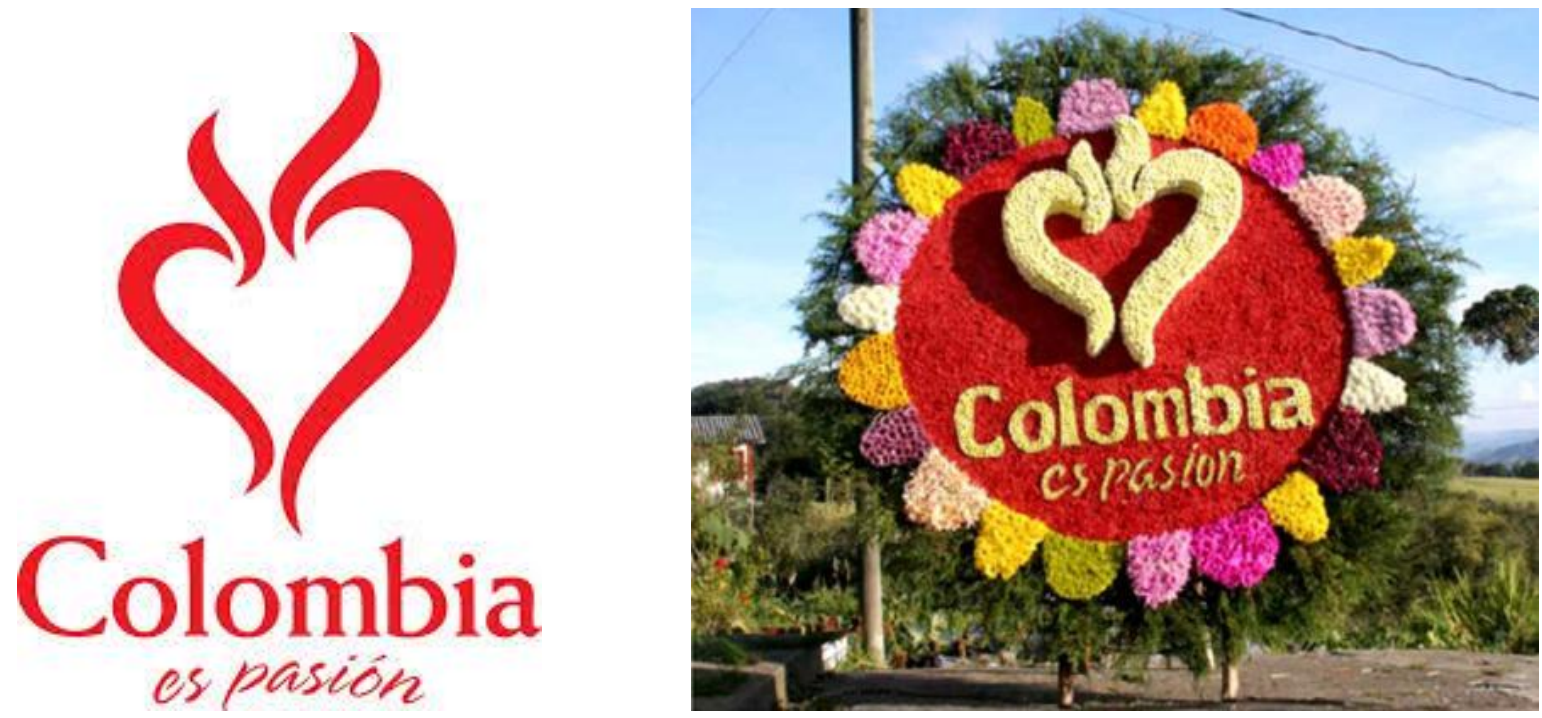

Fuente: recuperado de http://acdlc.ucoz.es/photo/colombia_es_pasion/1-0-17

Fuente: recuperado de http://www.fotolog.com/heimech/13868136/

En esta primera iniciativa se usaron estrategias como la creación de un equipo de ciclismo con el mismo nombre y logo, el lanzamiento de una canción con artistas colombianos, la presencia en eventos nacionales de carácter internacional y ferias de turismo en todo el mundo, la creación de una tienda con productos alusivos a la marca y una serie de comerciales: uno de ellos es en inglés y es narrado por una niña ${ }^{3}$, la cual habla de manera general del país en términos positivos, pero a diferencia de campañas posteriores no destaca lugares puntuales, solo específica las bondades naturales y territoriales del país, insiste lo buena y amable que es la gente y resalta algunos personajes famosos como Shakira y Gabriel García Márquez. De Medellín no se muestra mucho, solo se refiere a Colombiamoda (Feria de moda que se realiza antes de la Feria de las Flores), hay algunas esculturas de Fernando Botero y el edificio inteligente de las Empresas Públicas de Medellín ilustra la narración cuando se refiere a "ciudades modernas". Así que en un primer acercamiento a Colombia es Pasión se puede decir que la capital de Antioquia no tiene un protagonismo especial y mucho menos los silleteros dentro de la principal campaña de promoción del país.

Los demás comerciales son más recientes y tienen que ver con la estrategia "Colombia el riesgo es que te quieras quedar", que es una especie de juego de palabras, con el que se parte de la imagen negativa del país para demostrar que la

https://www.youtube.com/watch?v=HyFXo WLJVI 
violencia y el narcotráfico hacen parte del pasado y que en el territorio nacional existe mucho más que droga y guerra, principales referentes de Colombia en el mundo. Así que un primer video ${ }^{4}$ lanzado en 2009 se dedica en su primera parte a hablar de los prejuicios que tiene el mundo sobre el país, como que todos sus habitantes cultivan cocaína o marihuana y que habitan precarias viviendas, tomando como referencia diferentes escenas de películas de Hollywood en las que el país aparece como una selva en permanente conflicto. $Y$ pasa a resaltar lugares, personajes y características del país, destacando que el 99 por ciento de los colombianos son personas "buenas, trabajadoras, honestas y no cultivan marihuana, cocaína o amapola". Aquí no hay referencias específicas a Medellín ni a ninguna ciudad en especial, más bien hablan de cifras nacionales. Aunque puede verse una de las imágenes emblemáticas de la ciudad: al mencionar la frase "tome el riesgo de conocer un país que vive en este milenio" se muestra el metro de Medellín pasando al lado del Palacio de la Cultura.

La campaña continúa en 2011 con otra serie de comerciales, en los que se retoma algo ya iniciado en el anterior video y que sigue en la campaña actual que es el uso de testimonios de extranjeros: una serie de ciudadanos de diversos países enseñan las diferentes regiones de Colombia ${ }^{5}$. En el caso de Medellín la modelo argentina Valeria Walter en 40 segundos muestra diferentes espacios de la ciudad, mientras dice que llego a Colombia hace 7 años y lleva 3 viviendo en Medellín y dice que "es el futuro de la moda, es una ciudad que crece, que florece".

A partir de septiembre de 2012 Colombia es Pasión cambia por Marca Colombia con una nueva imagen, con la que se pretende una idea más moderna y flexible, con la cual se "busca crear una imagen integral del país en el extranjero basada en hechos comprobables, únicos y diferenciados en los ejes de cultura, exportación, turismo e inversión", según puede leerse en su página oficial http://www.colombia.co/.

4

https://www.youtube.com/watch?v=3pmEtrTn7Bc

5

https://www.youtube.com/watch?v=xZepZ8cJ0uU 


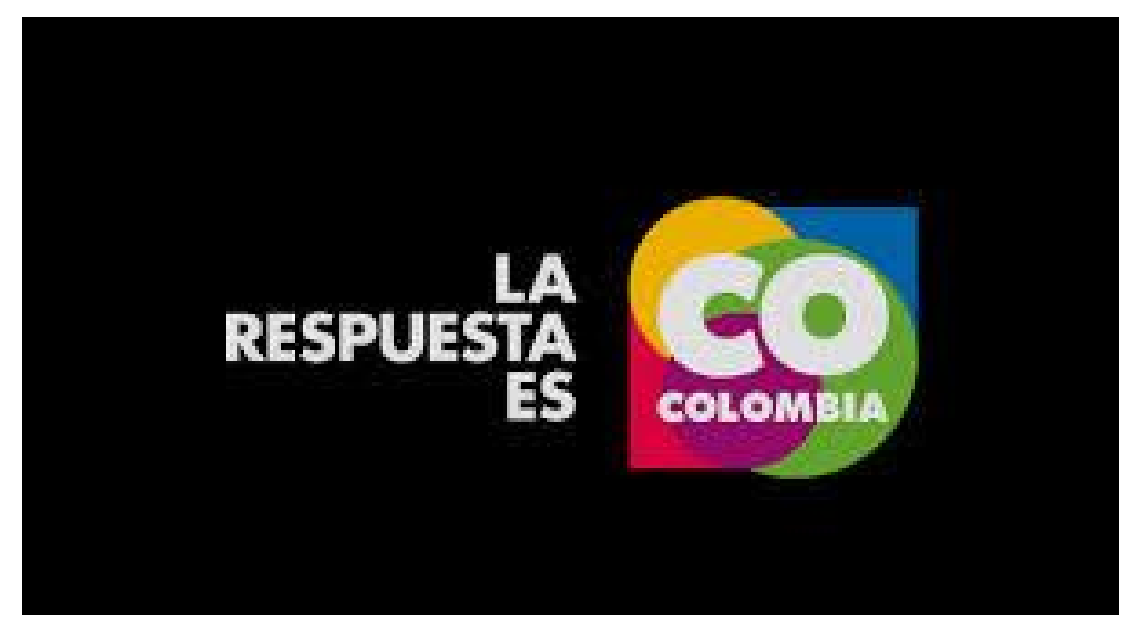

Fuente: www.colombia.co

Su principal estrategia ha sido "La respuesta es Colombia" que tiene como eslogan "Colombia es realismo mágico" lanzado en mayo de 2013 y en el que se continúa con los testimonios de foráneos, "se trata de una expresión que resume la esencia de esas vivencias que relatan los extranjeros tras su paso por el país y que consolida las campañas anteriores con las que se logró un cambio de percepción y mostrar los encantos de los destinos y los avances en cuanto a seguridad y estabilidad 'El riesgo es que te quieras quedar" según indica un comunicado de prensa del Ministerio de Industria, Comercio y Turismo y Procolombia, la entidad encargada de la promoción del turismo internacional, la inversión extranjera y las exportaciones no tradicionales en Colombia.

El video oficial de "Colombia es realismo mágico" ${ }^{6}$ se dedica a destacar diferentes espacios y eventos del país, entre ellos la Feria de las Flores, que va del minuto 0:55 hasta el 1:04 e inicia con la imagen ya mencionada del metro de Medellín en el momento en el que pasa por el Palacio de la Cultura para seguir mostrando las flores y los silleteros en su desfile, mientras el narrador dice "las flores no están en los jardines sino que se pasean por las calles". Esta campaña también tiene un brochure de 156 páginas, en las que menciona a Medellín en varias oportunidades: dentro de las ciudades capitales, después de Bogotá y antes de Cali; en Colombia es multidestino, apartado en el que se muestran 16 destinos en total; en gastronomía; y dentro de Fiestas, ferias y eventos culturales, tal vez el punto que más interesa a esta investigación.

Ya el presidente Juan Manuel Santos lo anuncia en el "saludo" que da al inicio del catálogo, "gracias a su mestizaje y a la combinación de culturas autóctonas,

6

https://www.youtube.com/watch?v=0njQwjb3GaE 
europeas y africanas, Colombia ofrece un abanico de manifestaciones populares, ferias y fiestas, como el Carnaval de Barranquilla y el de Negros y Blancos en Pasto, la Feria de las Flores de Medellín, la Semana Santa de Popayán, el Festival de la Leyenda Vallenata en Valledupar, entre otras celebraciones y posibilidades que usted encontrará en esta publicación". Una de las páginas del folleto la dedica a la Feria y su imagen principal es un silletero.
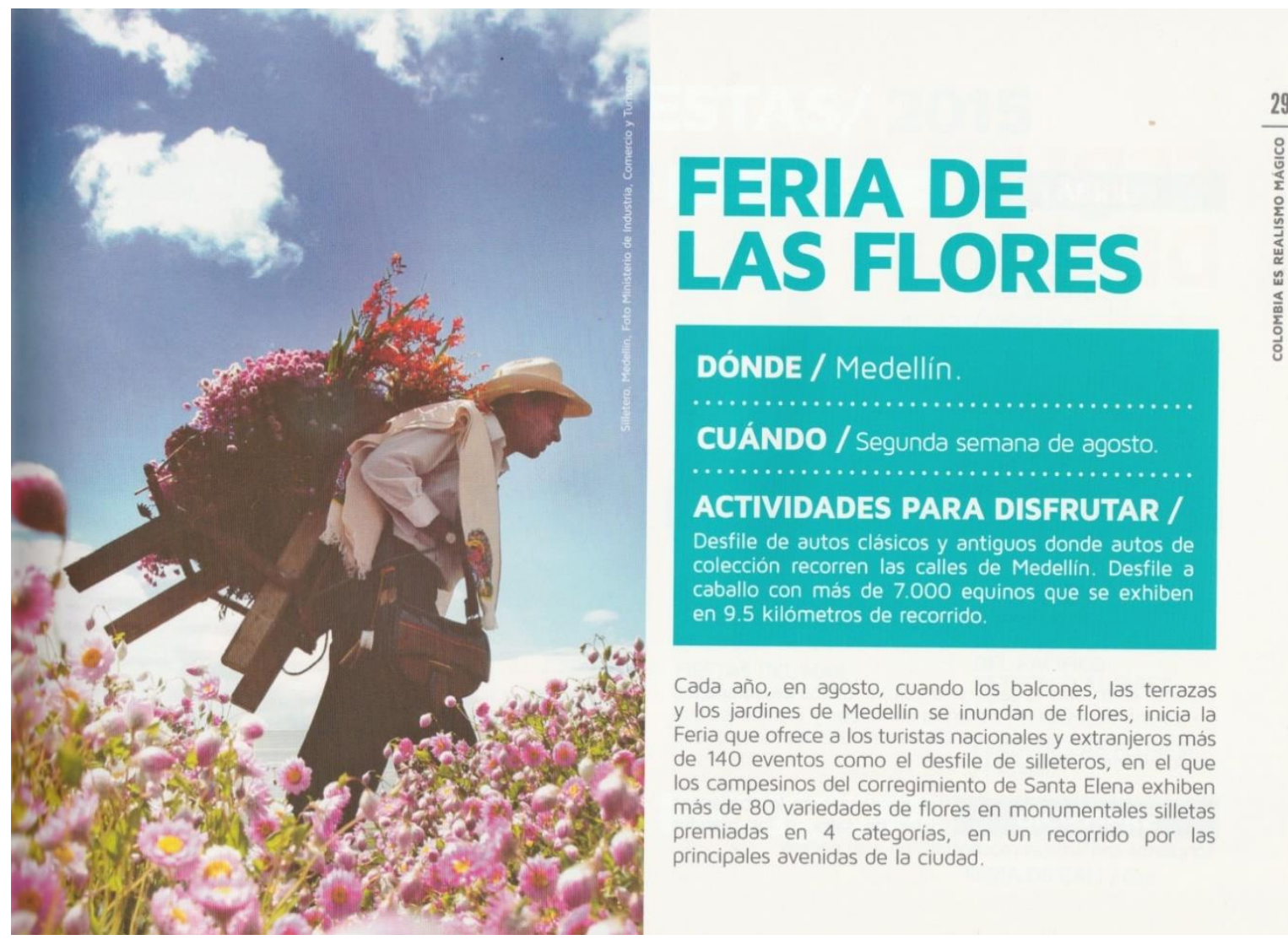

\section{DóNDE / Medellín.}

CUÁNDO / Segunda semana de agosto.

ACTIVIDADES PARA DISFRUTAR / Desfile de autos clásicos y antiguos donde autos de colección recorren las calles de Medellin. Desfile a caballo con más de 7.000 equinos que se exhiben en 9.5 kilómetros de recorrido.

Cada año, en agosto, cuando los balcones, las terrazas y los jardines de Medellin se inundan de flores, inicia la Feria que ofrece a los turistas nacionales y extranjeros más de 140 eventos como el desfile de silleteros, en el que os campesinos del corregimiento de Santa Elena exhiben más de 80 variedades de flores en monumentales silletas premiadas en 4 categorias, en un recorrido por las principales avenidas de la ciudad.

Fuente: Brochure Colombia es realismo mágico, 2013.

También dice que

"proclamada en 2013 como la ciudad más innovadora del mundo es sede de los principales centros financieros e industriales del país, dentro de los que se destacan los sectores textiles, de confecciones, telecomunicaciones y automotriz. Es conocida como la 'ciudad de la eterna primavera' por su clima privilegiado durante todo el año".

Más adelante menciona "lo que debes hacer" y tres de los cinco puntos que menciona apuntan a los objetos de investigación de esta tesis: la Feria de las Flores, la transformación de Medellín y el Desfile de Silleteros. 
El primer atractivo al que se refiere es a la feria, de la cual menciona varias actividades destacadas, después pasa a referirse a la transformación de la ciudad e indica que como tercer atractivo el turista debe "ser testigo de la reconocida muestra del progreso, transformación social, desarrollo e innovación que la consolida como una capital moderna" y como cuarto atractivo el desfile de silleteros, "donde se muestra la expresión artística de la región a través de laboriosos trabajos artesanales con 80 variedades de flores, adornando sillas cargadas a la espalda durante la exposición".

Es tal vez la campaña nacional en la que más importancia se da a los silleteros y su feria, de manera que una primera interpretación al respecto es que este personaje no tiene tanta relevancia en los inicios de la internacionalización turística del país y hay que buscar su consolidación como imagen del paisa y antioqueño en las campañas locales, pero la "nueva" Medellín como experiencia destacada en Colombia si es un elemento usado de manera importante para la promoción del país.

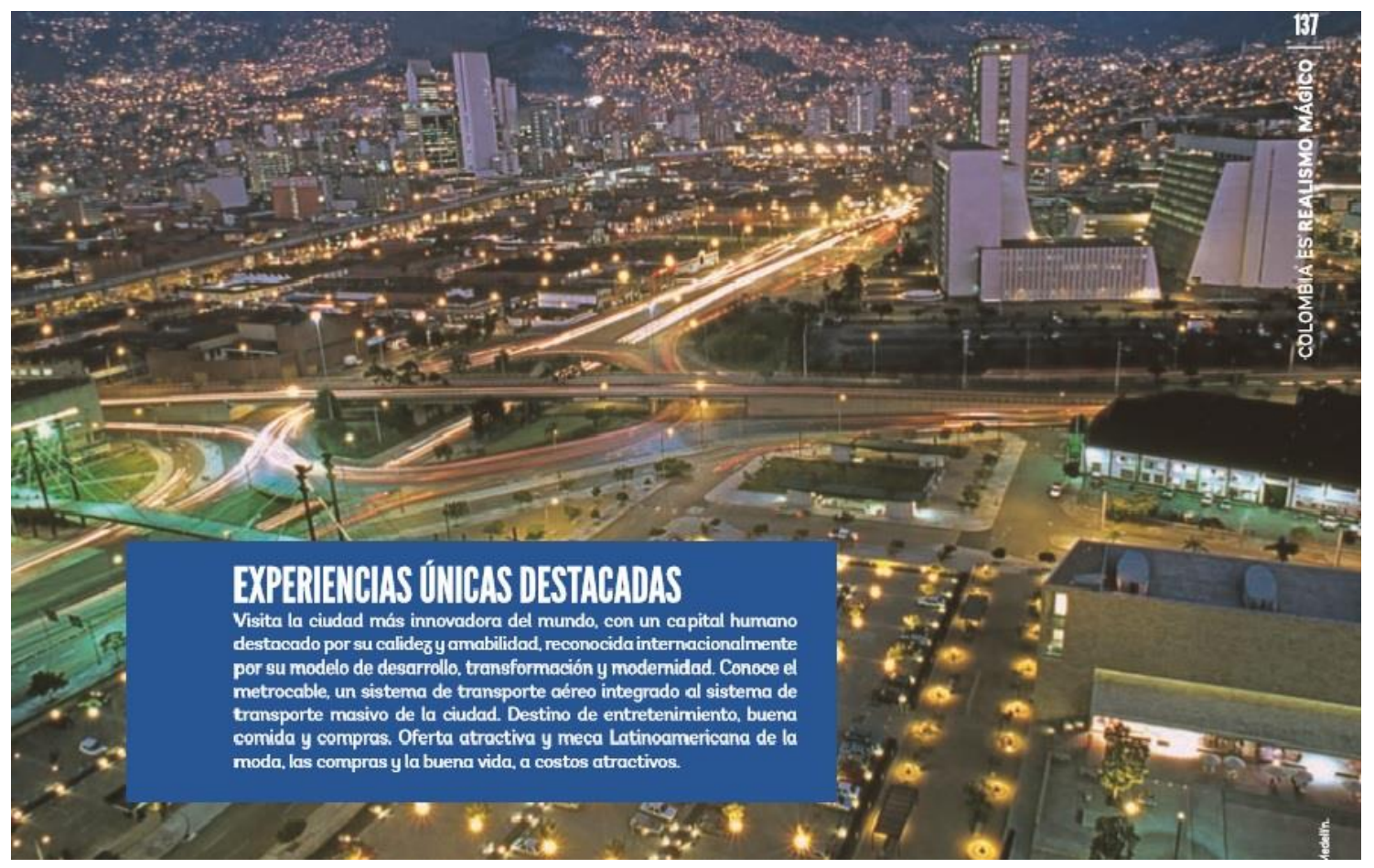

Fuente: Brochure Colombia es realismo mágico, 2013.

\subsubsection{La marca Medellín}

Tal vez la ciudad más afectada internacionalmente por la imagen negativa del país fue Medellín por haber sido uno de los epicentros de la violencia, tal como ya se 
ha dicho, y por esa razón también es la que mejor refleja los avances del país en materia de seguridad y economía, se presenta como el mejor ejemplo de la nueva cara de Colombia y ha tenido todo un proceso de promoción local para mostrar dicho proceso de transformación.

En 2002 la Alcaldía y la Cámara de Comercio de Medellín para Antioquia crearon el Medellín Convention \& Visitors Bureau, "con el objetivo de tener una institución encargada de la promoción de la ciudad como destino de turismo de negocios" según lo explica su página oficial http://www.medellinconventionbureau.com/ donde agrega que se sumaron 80 empresas del sector privado y que en 2005 se fusionó con la Oficina Privada de Fomento y Turismo, hasta entonces encargada del turismo en la ciudad.

Desde entonces esta entidad inició una serie de estrategias para promocionar la región en el mapa mundial, gracias a las cuales según las cifras más recientes durante la elaboración de esta investigación, en el primer semestre de 2014 el turismo internacional creció en un 4,6 por ciento y durante todo el año ingresaron un $12,15 \%$ más de viajeros en comparación con el año inmediatamente anterior, para un total de $549.455,158.425$ de ellos extranjeros. Para este momento también tienen unas metas claras, con el fin de seguir mejorando estos índices en el año 2015: captación de 105 eventos de carácter nacional e internacional, realización de al menos 120 eventos del mismo tipo, incremento del 61 por ciento de pasajeros internacionales con respecto al 2010 y del 21 por ciento de los nacionales en el mismo periodo de tiempo, según la misma página web.

En una entrevista hecha a Adriana González, gerente del Medellín Convention Bureau ${ }^{7}$ en el programa Negocios en Telemedellín en 2012, explica la manera en que la ciudad se ha mercadeado en el mundo para lograr convertirse en la tercera ciudad más visitada de Colombia, después de Bogotá y Cartagena y la única que ha mejorado sus índices en el último año: "realmente vender la ciudad es como vender un producto [...] salimos al mercado a competir con otros productos, entonces en nuestro caso el producto es Medellín como destino y lo que tenemos que identificar es cuáles son las fortalezas de nuestro producto y cuáles son las debilidades y con quién estamos compitiendo".

Agrega que el primer trabajo es de "prospección" y que cuentan con una base de datos de 500 registros entre los cuales identifican aquellos eventos que cumplen las condiciones que le interesan a la ciudad, de manera que existen investigadores

7

https://www.youtube.com/watch?v=yDxSxiGktR0 
dedicados a este punto específicamente para garantizar mayor éxito a la hora de competir con otras ciudades para lograr ser sede de los diferentes certámenes.

La captación de eventos es una de las funciones del Bureau y de esta manera han logrado que Medellín sea el anfitrión de certámenes de talla mundial, que si bien no tienen mucho significado para otras ciudades en Latinoamérica y el mundo, para Medellín, cuna de Pablo Escobar, representan la superación de su pasado conflictivo frente al mundo: Asamblea de la Organización de Estados Americanos (2008), Reunión Anual de Gobernadores del Banco Interamericano de Desarrollo (2009), Juegos Suramericanos (2010), Bienal Iberoamericana de Arquitectura y Urbanismo (2010), Congreso Iberoamericano de Cultura (2010) y Foro Urbano Mundial de Naciones Unidas (2014) son solo algunos de los más destacados.

Pero también existen otras estrategias como la coordinación de visitas internacionales de empresarios, periodistas y gobernantes extranjeros, la participación en eventos internacionales de turismo y negocios como Imex (Feria Internacional de Turismo de Negocios) de Frankfort o Fitur de Madrid (Feria Internacional de Turismo de Madrid) y la creación de diferentes campañas para realizar dicha promoción.

Una de estas iniciativas es la marca "Medellín jes primavera!" lanzada en 2010 y en la que según Ignacio Ramos, presidente de Ciac, la firma encargada de crear la marca, el término resurgimiento era la clave, porque el pasado es pasado, así que la idea fue lograr una fusión de un pasado positivo representado por la primavera, con un mensaje racional que podría traducirse en que es segura y se puede visitar (Redacción Medellín, 2010).

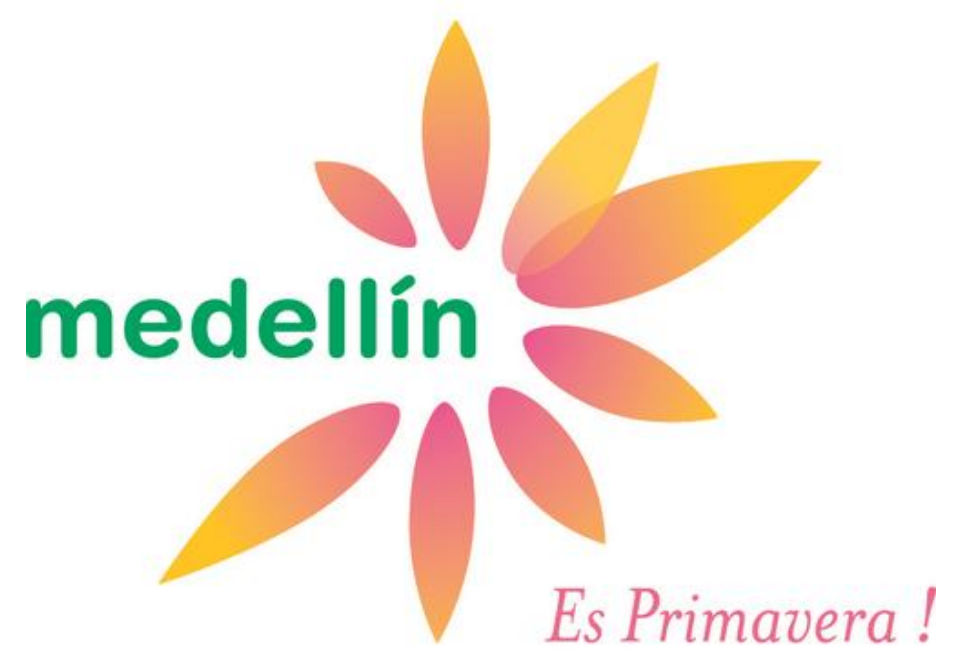

Fuente: @TurismoMdellin 
Diana Marcela Quintero Calle en su trabajo "Una propuesta de marca para Medellín basada en los casos de Barcelona y Córdoba" asegura que esta estrategia no ha tenido buenos resultados y que nunca ha sido más fuerte que el eslogan político que propone cada alcalde durante su administración. Según ella,

“'Medellín jes primavera!' no fue adoptada por los ciudadanos, quizá porque no se le tuvo en cuenta en su construcción y de esa manera no es posible una apropiación de la misma por parte de los medellinenses. Una marca ciudad que no es apropiada por sus habitantes, ni los refleja o genera conexión emocional con ellos, tiende al fracaso" (Quintero, 2014).

Como ya hemos dicho no es objetivo de este texto juzgar o analizar la efectividad o no de este tipo de tácticas sino más bien observar la manera en la que se vinculan a esta investigación. Así que la última campaña lanzada por la marca es "Medellín, una ciudad que sorprende", la cual cuenta con varios vídeos promocionales, entre los que se destaca uno principal de 4:02 minutos de duración ${ }^{8}$, el cual dedica 17 segundos al desfile de silleteros, con imágenes del evento y sus protagonistas, en los que se puede escuchar: "nuestro punto más alto es el tradicional desfile de silleteros donde un grupo de hombres y mujeres desfilan nuestras principales calles ofreciendo el detalle de cada uno de los ornamentos que con dedicación han preparada para esta especial ocasión".

El común denominador de esta promoción es la nueva Medellín como ejemplo de transformación para el mundo y el impulso de sus atractivos turísticos principales, entre los que se cuentan los eventos locales y la Fiesta de las Flores. Incluso cuando no se trata específicamente del tema, por ejemplo durante el Mundial de Fútbol de 2014 la campaña "Medellín te queda por siempre" mezclaba los puntos positivos de la ciudad con la pasión por este deporte, así que personas de diferentes ciudades de Colombia y otros países hablaban de las bondades de Medellín y de su equipo favorito para ganar la Copa Mundial, así que uno de los entrevistados es un inglés que se refiere a la Feria de las Flores "puedes encontrar rumba (fiesta), silletas, flores y todo" como la razón por la que siempre recordará a Medellín.

El portal Medellin.travel del que ya se habló al inicio del capítulo también tiene una vinculación directa con el Medellín Convention Bureau y en su campaña "Medellín, el lugar donde comienza lo inolvidable" que tiene un vídeo ${ }^{9}$ de 5:47 minutos dedica

8

https://www.youtube.com/watch?v=uGo8hvVIWil

9

https://www.youtube.com/watch?v=iYXBPA46bxI 
entre 2:35 y 2:50 a los silleteros y sus obras. El mismo portal tiene en su canal de Youtube con un total de cuatro vídeos dedicados a los silleteros, una serie que lleva por título Silleteros de Medellín-Patrimonio para el mundo ${ }^{10}$ y son protagonizados por la silletera Ana Fabiola Ramírez, quien en el primer video habla del orgullo que tiene por su tradición, de Santa Elena como tierra de amor, de alegría, "de flores todo el año" y cuenta su historia familiar silletera, que empieza con sus abuelos participando en el primer desfile al lado de otros 17 campesinos, continúa con sus padres hasta llegar a ella, que espera que sus hijos mantengan el legado en el futuro.

El segundo video se refiere al vestuario típico del silletero: falda negra pintada a mano, camisa blanca estilo campesino, delantal blanco, chalina y pañuelo para las mujeres y pantalón negro, camisa blanca de manga larga, sombrero aguadeño y cubierta del machete para los hombres; en el tercero hace alusión a la pasión que siente por la tradición porque dice que se le anima el alma y no siente el cansancio al llevar la silleta a cuestas por el orgullo de demostrar que los abuelos y los papás empezaron con la tradición y ella puede seguirla, y "ver que la gente lo aplaude a uno porque somos unos artistas" y se "demuestra lo que es Santa Elena en un arreglo floral"; el último es una invitación directa para que conozcan la cultura silletera durante las vacaciones.

\subsection{Los resultados del mercadeo: el mundo habla de la "nueva Medellín"}

"¿Tradición? Tranquilo. Se huele en el aire cuando la Ciudad de la Eterna Primavera florece en medio del verano para la anual Feria de las Flores en agosto. Desde hace 58 años este festival, llena las calles con color caleidoscópico, una atractiva evidencia de la metamorfosis de Medellín" (Baker, 2014).

Así finaliza el artículo con el cual National Geographic destaca a Medellín como el segundo destino recomendado entre sus "Mejores viajes 2015", solo superado por la isla italiana Córcega y que convierte a los silleteros en prueba y mensaje de la transformación de Medellín al concluir una publicación que también resalta su fama debido a las flores, la llama "el milagro Medellín", "metrópoli modelo" y hace un recorrido por la manera en la que se "rehabilitó" pasando del terrorismo al turismo.

https://www.youtube.com/watch?v=vAY18rQkCTM\&list=PLbSoL9xO1qMqwID2ZE2Xx_T7M1RUKJo6 
Pero no es el único texto con este enfoque, el diario chileno especializado en economía y negocios El Pulso, también se refiere a la "nueva Medellín" y sus silleteros en una publicación del 30 de agosto de 2013:

"Agosto es el mes de las flores en Medellín. Tanto, que la ciudad le dedica nueve días a una feria donde los desfiles de silleteros -campesinos que cargan coloridos arreglos florales en sus espaldas- alcanzan el nivel de Patrimonio Cultural de Colombia.

Pero no sólo de flores vive la llamada ciudad de la eterna primavera. Intentando dejar atrás el estigma del narcotráfico y la delincuencia de los años '90 tras la derrota al cartel de Medellín, la capital de Antioquia ha logrado dar pasos importantes, como transformarse en la ciudad más innovadora del mundo (según Urban Land Institute, Citi y Wall Street Journal Magazine)" (Namur, 2013).

Un lead con el que el medio de comunicación evidencia la importancia de los símbolos tradicionales de Medellín para la nueva imagen de la ciudad y hace un vínculo directo entre los silleteros de Santa Elena y la transformación de la capital antioqueña, un contraste entre el pasado y el presente, que le sirve de preámbulo para señalar su nueva posición como "más innovadora del mundo". El texto señala que con un PIB de 17.069 millones de dólares (en 2010) Medellín representa el 8 por ciento de la economía del país, compite "codo a codo con la capital y que incluso le gana a Bogotá en algunas cosas" y concentra el 20 por ciento de las mayores empresas del país, un punto en el que señala que "Proexport, la agencia de promoción de exportaciones, turismo e inversión también ha jugado un rol fundamental en atraer empresas a la región".

Son solo un par de ejemplos que demuestran la manera en que esas estrategias gubernamentales y el mercadeo de ciudad empiezan a dar resultado, pues ver la prensa internacional es una forma de medir el éxito de dichas tácticas y saber cómo se ve viendo hoy Medellín en el exterior: gana concursos internacionales de innovación ${ }^{11}$, es elegida como la mejor ciudad de Latinoamérica para vivir ${ }^{12}$ y uno de los mejores destinos del mundo para disfrutar de la jubilación ${ }^{13}$.

Concurso City of the Year 2013, organizado por el diario estadounidense Wall Street Journal y Citi Group. Medellín fue finalista al lado de Tel Aviv y Nueva York, en el concurso en el que participaron 200 ciudades.

Encuesta global sobre el estado de las Smart Cities en 2014 de la multinacional de consultoría y tecnología Indra. 
En otro artículo publicado por el periódico The australian el 30 de agosto de 2014 hay tres fotografías ilustrando el contenido referido al cambio de imagen de Medellín: un silletero, el Parque Biblioteca España y el metro con el Palacio de Cultura de fondo. En él además puede leerse sobre cómo "fuera de Colombia, Medellín todavía puede ser sinónimo del rey de la cocaína Pablo Escobar y su reinado de terror. Pero la ciudad ha sido escenario de una notable recuperación desde aquellos días oscuros y la capital de la montaña ahora está considerada como una de las ciudades más seguras de América Latina" y agrega que "es una historia de rejuvenecimiento urbano a rivalizar con la de Bilbao (España). Si bien no hay Gehry Guggenheim (no todavía), la ciudad está llena de monumentos que hablan de su transformación - como el ex alcalde Sergio Fajardo lo expresó - 'Del miedo a la esperanza'” (Hill, 2014)

También dedica un párrafo entero a los protagonistas del Desfile para decir que

"Los silleteros, o agricultores de flores, de Santa Elena son una institución, famosos por hacer la caminata nocturna por la montaña para vender sus productos en el mercado cada mañana a las 6:00. Hoy hacen el viaje en camiones y furgonetas, pero su contribución al tejido social de Medellín todavía se celebra cada año en el festival de agosto, cuando los silleteros desfilan por las calles con 'silletas' de madera (sillas, de ahí su nombre) atados a sus espaldas y frentes. Cada una está decorada con arreglos florales que contienen al menos 25 flores diferentes" (Hill, 2014)

Incluso hay una alusión a la cultura paisa, pues el periodista dice que los habitantes de la ciudad son "conocidos como paisas, tienen la reputación de ser muy trabajadores, orgullosos, emprendedores; para que yo añadiría encantadores".

Otras publicaciones, como las de la agencia de noticias estadounidense $A P$ el 12 de diciembre de 2014 también se refieren a la "nueva Medellín": Dallas News, replica la primera de ellas el 12 de diciembre para decir que "la ciudad que fue sacudida por la violencia del narcotráfico ha sufrido una transformación social y económica" (Associated Press, 2014); mientras que The Columbus Dispatch publica una segunda nota en la que se resalta que

Recomendada por la editorial Kipling y The Huffington Post. 
"20 años atrás era una de las ciudades más peligrosas del mundo. Medellín es la segunda ciudad más grande de Colombia, logró fama mundial en los ochentas y noventas bajo el dominio de Pablo Escobar, el capo de la droga conocido como el 'rey de la cocaína' y uno de los criminales más ricos. Sin embargo, en el tiempo transcurrido desde su muerte en 1993, la ciudad se ha convertido en un ejemplo mundial de desarrollo urbano ganando un premio como ciudad innovadora del año en 2013. Los problemas de Colombia no han terminado, pero caminando por las calles afluentes de Medellín se puede perdonar por olvidar" (Harpaz, 2014).

En 2013 Medellín recibió el premio como ciudad más innovadora del mundo, tras superar a Tel Aviv y Nueva York, en un concurso realizado por Wall Street Journal, Citi y Urban Land Institute, ante lo cual este último organismo dijo

"Pocas ciudades se han transformado en la forma en que lo ha hecho Medellín, la segunda ciudad más grande de Colombia, durante los últimos 20 años. La ciudad construyó bibliotecas públicas, parques y escuelas en los barrios de ladera pobres y construyó una serie de conexiones de transporte desde allí hasta el centro comercial e industrial. Las conexiones incluyen un sistema de metrocable y escaleras mecánicas para las empinadas colinas, reduciendo los tiempos de movilidad, estimulando la inversión privada, la promoción de la equidad social y la sostenibilidad ambiental" (http://uli.org).

El artículo "Por qué convertir a Medellín en el Silicon Valley de América del Sur es ideal para el turismo" publicado por Skift se refiere a este tema diciendo que "en un esfuerzo por hacer de Medellín un innovador centro de negocios y líder de diseño urbano contemporáneo, la ciudad también se ha convertido en uno de los destinos turísticos internacionales más sonados" (Shankarman, 2013), al tiempo que ofrece cifras de cómo han bajado los homicidios y la violencia y la manera en que ha aumentado el turismo.

Forbes también tiene un texto titulado "La transformación de Medellín, y la compañía sorprendente detrás de ella" del 27 de enero de 2014, en el que se refiere a las Empresas Públicas de Medellín (EPM) como una entidad fundamental para el famoso cambio y resalta el "valor de diseño urbano y espacios públicos en la configuración del desarrollo equitativo de una ciudad" y pone a la capital antioqueña como

"Un ejemplo de ello se ve en Medellín, Colombia, donde una asociación única entre la empresa de servicios públicos Empresas Públicas de Medellín (EPM) y la ciudad ha dado oportunidades económicas en los barrios marginados, fomentado comunidades inclusivas, y atrajo el reconocimiento internacional y la inversión" (Ashoka, 2014). 
En este mismo sentido, The Economist en su artículo "El problema de los milagros" habla de las dos razones que transformaron a Medellín y por las que es difícil replicar su "modelo de transformación" en otras ciudades: en primer lugar dice que el cambio se dio gracias a EPM, una de las compañías mejor administradas de Suramérica y que en los últimos diez años "ha enviado 3.2 mil millones de dólares al ayuntamiento, en torno al 25 por ciento del presupuesto municipal"; y en segundo a una "cultura política y económica única, que algunos han llamado el 'corporativismo católico", a la cual haremos referencia de nuevo más adelante en el capítulo referido a la "cultura paisa". La publicación británica también da la "simple receta" con la que Medellín dejó de ser la "capital mundial del crimen": "la solución fue un cambio de imagen urbana radical con un propósito redistributivo: los mejores proyectos estaban reservados para las zonas más pobres y violentas" (Redacción Américas, 2014)

Lonly Planet, una de las mayores editoriales de guías de viajes del mundo, también tiene un artículo llamado "El renacimiento cultural de Medellín" (Bonuccelli, 2009), en el que predomina el contraste entre la "vieja Medellín" de violencia y droga y la nueva, en la que hay esculturas en las calles, bibliotecas en los barrios marginales y jóvenes haciendo música en las plazas, "el caos todavía abunda, pero un caos de color, energía, movimiento y vida" y agrega que tener la oportunidad de "experimentar un resurgimiento de Medellín debe por lo menos, acelerar el pulso", de manera que más que destacar espacios o planes específicos se dedica a promover la transformación de la ciudad, tal como los anteriores medios y muchos otros que por cuestión de tiempo y espacio no alcanzarían a mencionarse en este trabajo, pero que llegan a ser varias decenas.

\subsection{La "nueva Medellín" y los silleteros en la prensa local}

"Medellín se abrió al mundo, prueba de ello es transportarse en el metro o pasar por alguno de nuestros museos o parques, sitios que aglutinan cientos de extranjeros que han hecho de ella uno de sus destinos preferidos. Y claro esta Feria de las Flores es un reflejo de esa transformación" (Melguizo, 2008)

Este apartado es el resultado de un rastreo de prensa que abarca desde los inicios del desfile en 1957, según la historia oficial del evento, hasta el año 2014, a través de dos diarios, elegidos teniendo en cuenta su circulación constante durante el período que le interesa a esta investigación, su amplia circulación y popularidad: El Tiempo, de cobertura nacional y El Colombiano, departamental. La idea es hacer un breve recorrido por la manera en la que estos medios trataron el desfile a través del tiempo, con el fin de detectar los puntos y momentos importantes para los silleteros y su desfile como un reflejo de la imagen positiva de Medellín, con el 
fin de continuar con el postulado que conecta a estos personajes símbolos de la región con la transformación de la ciudad.

En 2004 la Gobernación de Antioquia lanzó la campaña "Por la vida cada ciudadano puede ser silletero un instante", con el que pretendía que los habitantes de la ciudad pusieran una flor en una de las dos silletas monumentales dispuestas como símbolo de paz. Así lo destaca El Colombiano el 6 de agosto en su portada, un día antes del desfile de silleteros de ese año y en el interior explica que "el objetivo es buscar de manera simbólica la unión de todos por un bien que todos queremos, la paz", citando a Héctor Valencia, miembro de la Secretaría de Agricultura, así como las intenciones de quienes pasaron por el centro administrativo La Alpujarra (lugar en el que se encontraban las silletas) "Lo hago porque estoy 'mamao' de la guerra. Sé que esto no va a dar la paz, pero que se den cuenta de que cada flor, es alguien que la pide a gritos" dijo al periódico regional Carlos Arturo Sánchez, quien se acercó a poner una flor.

Es tal vez el primer momento importante en el que se hace una conexión directa entre los silleteros y la "nueva Medellín", que en ese momento todavía no es llamada así porque su transformación todavía no se ha producido, pero seguramente sí ha sido planeada y empieza a evidenciarse con iniciativas como esta, en la que el instrumento distintivo de estos personajes (la silleta) es usado para dar un mensaje de rechazo a la violencia, como antónimo de guerra, como aporte a la paz, y aunque no es la primera vez que se recurre a la fiesta y al desfile para mostrar la cara positiva de la ciudad si es la primera en la que se relaciona al desfile con la ciudad libre de violencia.

Y es que los desfiles de los años 2004 y 2005 marcan un punto importante en este recorrido periodístico, pues ambos medios destacan los mensajes a favor de la paz y en contra del conflicto que llevaron a sus espaldas los participantes del evento en esas oportunidades: "las flores tomaron formas de mensajes de paz y convivencia durante el 47 desfile de silleteros" resalta El Colombiano en su portada del 8 de agosto, un día después de la principal actividad de la Feria de las Flores en 2004, mientras que El Tiempo dice en un artículo denominado "Silleteros despidieron la Feria" del 8 de agosto de 2005 que ese año la paz fue el tema que predominó en las silletas y que también hubo frases alusivas al secuestro y al desplazamiento forzado.

Tampoco se pueden obviar detalles como el nombre de la sección especial dedicada a la Feria de las Flores en el periódico El Colombiano en 2008, "Medellín florece joven y en valores" o el testimonio del ganador del segundo puesto en silleta emblemática en 2010, Luis Felipe Londoño, quien le explicó a ese mismo diario como "quise demostrar que sí se puede una ciudad sin violencia". 
Así es como esta "tradición" empieza a aportar a la formación de la imagen de una nueva ciudad que reclama la paz y poco a poco lo va logrando hasta llegar a un segundo momento importante después de 2008, cuando ya se reconoce el cambio y es necesario empezar a decírselo al mundo como menciona Jorge Melguizo, secretario de Cultura Ciudadana de Medellín, en un editorial del especial de El Tiempo denominado "Medellín, capital de la vida" publicado el 7 de agosto de 2008 en el diario nacional: "pensando en que hay una ciudad para cuidar y vivir, una ciudad que una vez más le dice a todo el planeta que la violencia no será bienvenida nunca más y que estamos en nuestros mejores días. Así que a seguir la fiesta y a disfrutar de esta capital de la vida" o como subraya El Colombiano el 7 de agosto de 2011 al citar a la directora del Medellín Convention Bureau, Adriana González, "esta festividad significa para Adriana la oportunidad que tiene la ciudad para demostrar lo que ha crecido y lo que ha mejorado en materia de infraestructura y organización" (Castro Cardenas, 2011).

Otro aspecto para mencionar es la manera en la que los habitantes de Medellín y Colombia apoyaron estos postulados y creyeron en la nueva ciudad de los silleteros que resurge tras las cenizas de los carteles de la droga y la violencia del narcotráfico que empañaron la imagen del país en el exterior, "los silleteros son los verdaderos quijotes de la cultura itinerante que viaja con orgullo por muchos países del mundo mostrando la verdadera imagen de Colombia" escribe el lector Tomás Llano en la sección de Cartas al Director de El Colombiano el 6 de agosto de 2006.

Pero yendo a artículos más antiguos se puede ver que desde mucho antes se recurría a los silleteros y su desfile como elemento positivo de Medellín: "la marcha multicolor realizada por las calles medellinenses sirvió para mostrar la imagen positiva de una ciudad que tiene graves problemas pero que, además, trabaja con entusiasmo y optimismo por salir adelante" (Villa, 1994) dice El Colombiano en 7 de agosto de 1994 y que hoy en día puede leerse como una especie de premonición de lo que vendrá después.

Pero también un discurso bastante parecido al del mismo medio una década antes en lo referente al tema de la violencia, cuando en su portada del 12 de agosto escribió:

"También quieren la paz como la totalidad de los colombianos, los silleteros de Antioquia, quieren la paz. El deseo se hizo de manifiesto ayer en el XVII desfile floral realizado por la Avenida La Playa. Numerosas silletas fueron diseñadas simbolizando la paz. Puede ser que ese anhelo se haga realidad. Colombia se lo merece". 
Así que si ya en los ochenta la ciudad mostraba a los silleteros como parte de su imagen positiva, parece casi natural que después de 2004, cuando inicia la era Fajardo y con él "la transformación" continúen siendo fundamentales para proyectar la Medellín amable en la que se puede invertir, a la que se puede viajar y que deja en el pasado su historia de violencia, así como que una vez logrado el objetivo de posicionarla de esta manera en el mundo sigan siendo un atractivo importante de la marca Medellín.

Sin embargo, es interesante darse cuenta de cómo ha cambiado el tratamiento de la información: después de 2004 no son comunes temas conflictivos alrededor del desfile, mientras que en décadas anteriores es frecuente hallar textos sobre quejas por las dificultades que tienen los silleteros con sus cultivos de flores, lo mal que pagan su participación en el desfile e incluso sobre la "pérdida de la tradición" por culpa de la comercialización y la importancia dada a la fiesta desde aspectos como el ocio y el licor. Es decir, parece que a partir del momento en el que inicia el gran cambio de la ciudad, el evento y sus participantes dejan atrás sus diferencias y empiezan a centrarse en temas como patrimonio, cultura y tradición familiar.

\subsubsection{Generalidades}

Aparte de los datos aparentemente sueltos provenientes de la prensa, que al mismo tiempo se han articulado a este capítulo y seguirán incorporándose en los siguientes, hay una serie de puntos importantes para esta investigación que aporta este rastreo de prensa en El Colombiano y El Tiempo que vale la pena mencionar, por eso antes de continuar es importante explicar la manera en la que se hizo dicha búsqueda y mencionar algunas de las principales conclusiones extraídas.

El Colombiano es el diario más popular de Antioquia, de tendencia conservadora y tan arraigado en el imaginario popular de la región que es fácil encontrar personas que usen su nombre como sinónimo de periódico, de ahí el interés de este trabajo por indagar en la manera en la que presenta la información del desfile de silleteros:

"Fundado el 6 de febrero de 1912 por Francisco de Paula Pérez, se ha especializado en la investigación y generación de contenidos periodísticos para diferentes plataformas en las que provee a las audiencias de piezas multimediales informativas, de tendencias y de otros recursos destinados a mejorar la calidad de vida del individuo", (www.elcolombiano.com)

El Tiempo por su parte es el periódico con mayor circulación en Colombia, según el Estudio General de Medios de 2011. Nació en 1911 con una declarada tendencia liberal y hoy en día hace parte de un conglomerado editorial que se "ha 
consolidado como el grupo de medios más influyente de Colombia y en el principal proveedor de contenido", siguiendo su portal oficial. Pocos meses después de su fundación fue adquirido por la familia Santos, una de las más influyentes del país y a la cual pertenece el actual presidente de la república, Juan Manuel Santos. Entre 2001 y 2008 fue el único diario nacional, debido a la crisis de El Espectador que entonces se convirtió en semanario, y esa es la razón principal de su elección dentro de esta tesis.

De manera que el corpus de este rastreo fueron los textos publicados por ambos diarios entre 2004 y 2014 (años fundamentales para la transformación de Medellín) y entre 1957 y 2004 cada década (1957, 1964, 1974, 1984 y 1994), antes, durante y después del desfile, de manera que sea posible ver el impacto del evento en la prensa, tanto local como regional, las tendencias informativas del mismo y la manera en que han cambiado a lo largo del tiempo.

En total se analizaron 116 artículos, 27 portadas, dos menciones en portadas y dos reportajes gráficos. Tal como se esperaba, teniendo en cuenta la repercusión del evento en la región la mayor cantidad de textos se encontraron en El Colombiano, donde se hallaron 78 artículos, 21 portadas y dos reportajes gráficos, mientras que en El Tiempo había 38 artículos, 6 portadas y dos menciones en portada.

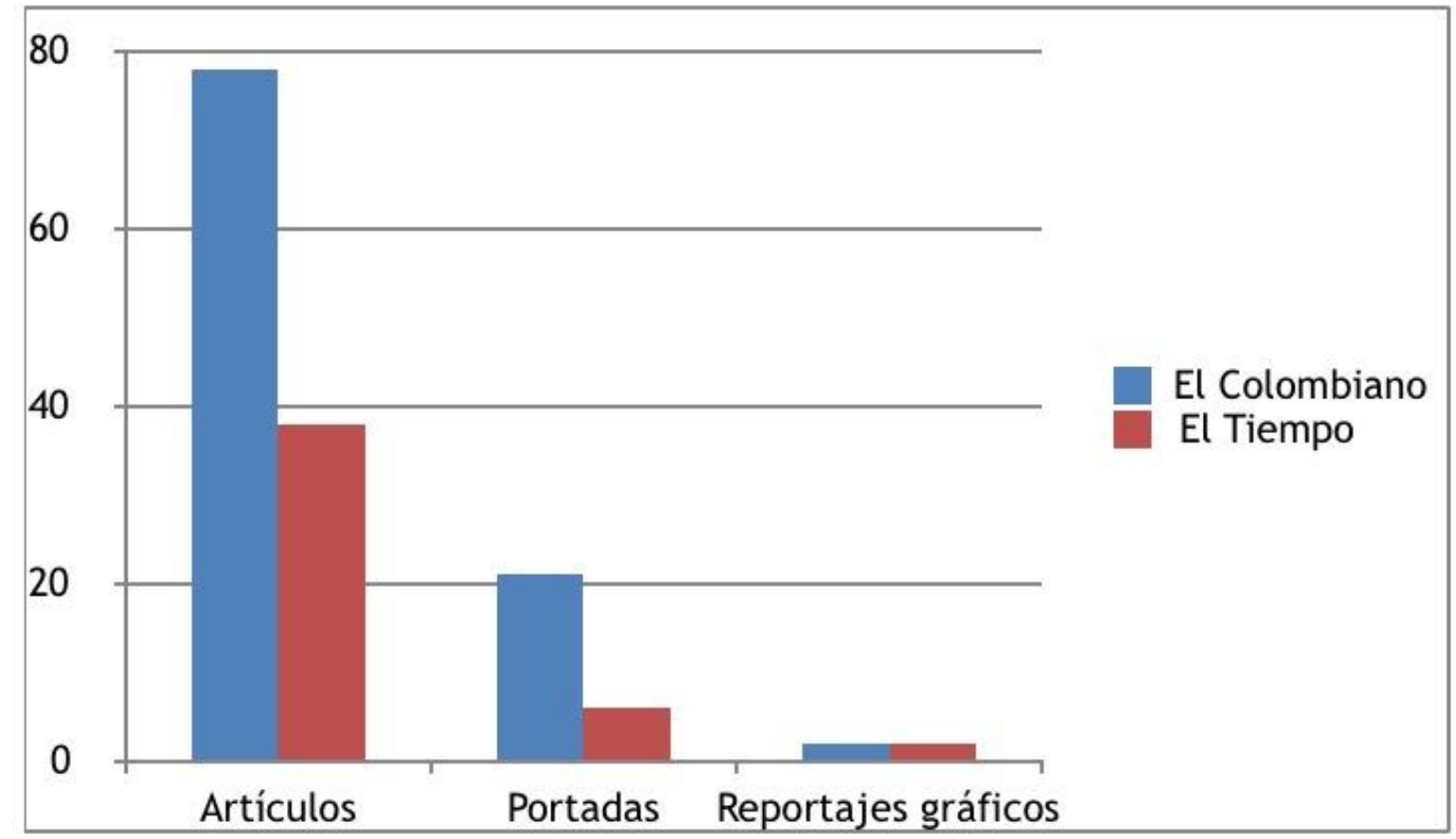

Para Sary Calonge Cole (2006) la representación social es "una forma de conocimiento de sentido común caracterizada por ser socialmente elaborada y compartida; con un fin práctico de organización del mundo; y que participa en el 
establecimiento de una visión de la realidad común a un grupo social o cultural determinado" (p. 76). Es importante conocer esta definición porque de ella se deriva el concepto de representación mediática, tomado a su vez de la teoría de la representación social propuesta por Serge Moscovici (1961) en su estudio "Princeps. La psychanalyse, son image et son public", donde se refiere a "la elaboración de un objeto social por una comunidad" (Moscovici, 1961 citado en Humanes, 2003, p. 41) el cual crea las bases para la investigación de la construcción social de la realidad (Calonge, 2006, p. 76).

Así que la representación mediática desde su dimensión pragmática se refiere al cumplimiento de un rol específico, el de mediar en la manera de comprender y sentir una realidad común instaurada en los diferentes grupos sociales existentes, lo cual está ligado a las condiciones de producción de la misma, en las cuales se manifiestan los poderes económicos y políticos (Calonge, 2006, p. 78). Aquí es donde entran en juego los medios de comunicación, que cumplen esa función de intermediación y al mismo tiempo constituyen una guía de opinión, pues amplían y actualizan esas realidades, y permiten el contraste y la comparación de diferentes puntos de vista.

"Cuando hablamos, entonces, de RM (representación mediática) nos referimos a las intenciones de los medios de comunicación que tienden a la difusión y no a la propaganda o la propagación" (Calonge, 2006, p. 79). Aunque hace falta aclarar que pese a su importancia en el proceso de construcción de los objetos sociales, Calonge no piensa que dicha acción dependa de los medios, aunque sí en la formación de una perspectiva común. Un punto que no queda del todo claro frente a los planteamientos antes expuestos, en los que pone a la prensa en medio de los hechos y la manera en que la representan los individuos.

Humanes (2003) también hace la relación entre medios y construcción de la realidad tomando como referencia a varios autores, "no nos enfrentamos a un fenómeno nuevo, pues que, desde Lippmann (1922) hasta Park (1916), pasando por el interaccionismo simbólico y la sociofenomenología de Schütz (1993), se ha señalado, implícita o explícitamente, el papel de los medios como creadores de conocimiento social" (p. 41).

Esta autora también tiene en cuenta el encuadre mediático o Teoría del Framing, como una herramienta interesante para el estudio de la cobertura periodística, pues permite describir el proceso mediante el cual los medios encuadran los acontecimientos sociales:

“(1) Seleccionando algunos aspectos de una realidad percibida, recibiendo mayor relevancia en un mensaje, asignándoles (2) una definición concreta, (3) una interpretación causal, (4) un juicio moral y/o (5) una recomendación para su tratamiento" (Entman, 1993 en Humanes, 2003, p. 42).

Raquel Rodríguez Díaz y Noemí Mena Montes (2008) también se refieren al tema resaltando la conexión entre los enfoques noticiosos y la manera en que el público hace de los acontecimientos: 
"Los experimentos realizados con diferentes enfoques informativos sobre un mismo tema llegan a la conclusión de que se puede modificar la interpretación que los ciudadanos hacen de la noticia y la evaluación de la misma a través de los enfoques o marcos de referencia cognitiva. Diversas investigaciones ponen de manifiesto que un cambio en los enfoques contribuye a modificar la evaluación e interpretación que hacen los ciudadanos sobre la información (Valkenburg, 1999 en Rodríguez et al., 2008, p. 343).

En el sentido teórico no se puede dejar de mencionar que la memoria como campo de estudio tiene en la prensa una de sus principales fuentes de investigación y por eso se mencionará la definición que usa Humanes en su artículo, "se refiere a cómo los grupos sociales recuerdan, olvidan o se reapropian del conocimiento del pasado social" (Páez, et al., p. 172 en Humanes, 2003, p. 42), con la que finalmente pretende explicar que la memoria colectiva se sustenta, en último término, en representaciones sociales sobre la realidad.

\subsubsection{Algunas interpretaciones}

Teniendo en cuenta estos conceptos se realizó un breve análisis cualitativo recurriendo a los tópicos más recurrentes en los textos cuantificados, de donde es posible decir que se encontraron nueve temáticas frecuentes, que al mismo tiempo están relacionadas directamente con esta investigación: la actualidad del desfile de silleteros, la tradición que hay tras él, su historia, sus protagonistas (los silleteros), su consideración como patrimonio, el día previo al evento en Santa Elena, los valores paisas que promueven, la violencia y la paz y la proyección internacional del desfile.

Antes de referirse a las transformaciones que ha tenido el tratamiento informativo del desfile de silleteros a lo largo del tiempo es interesante ver algunas cifras y tendencias extraídas de la presencia de estos puntos en ambos medios: tanto El Tiempo como El Colombiano enfocan la mayoría de sus artículos en la actualidad del desfile, con un 31 y 41 por ciento respectivamente y en segundo lugar tocan sobre todo el tema de la preparación del desfile en Santa Elena y la asistencia de turistas a las viviendas de los silleteros, en este caso se hace alusión a un 15 y 16 por ciento respectivamente. A partir de ahí es bastante diferente la manera en que cada diario aborda la información sobre el evento.

El periódico antioqueño se concentra mucho en los hechos antes y después del desfile de manera narrativa, a eso le dedica un 57 por ciento del contenido, el resultado de sumar las noticias referidas a la previa y al día del desfile; y en tercer lugar se refiere a los valores paisas y la proyección internacional con 8 por ciento cada una. Es interesante anotar que ambos puntos son casi los últimos tocados por El Tiempo, quien dedica un 7 por ciento a los valores 
paisas y apenas un 4 por ciento a la proyección internacional, lo cual resulta llamativo en la medida en la que se puede evidenciar a El Colombiano como un promotor de antiguos arquetipos regionales e impulsor de la "nueva Medellín" ante el mundo, lo cual no es tan importante en el periódico nacional, para el cual Antioquia es solo una región más que cubrir.

El Tiempo resalta otros puntos en tercer y cuarto lugar: los silleteros como protagonistas del evento son el foco del 13 por ciento de sus textos, en los cuales existe la intención de mostrar el lado humano de la fiesta, mientras que destacan el evento como tradición en un 11 por ciento de los casos, el mismo porcentaje con el que se hallan noticias relacionadas con la historia del desfile, lo que se puede explicar siguiendo la premisa de que además de los temas políticos de índole nacional, a este tipo de medios solo les interesan los temas sensacionalistas relacionados con "sucesos" como se llama en periodismo a la crónica roja o de tipo folclórico que sea lo suficientemente atractivo para interesar a todo el país.

Vale la pena detenerse en dos de los temas que interesan sobremanera a esta investigación, además de los valores paisas: violencia y paz y proyección internacional. Son asuntos con bajo porcentaje, pero que teniendo en cuenta la naturaleza de la información resulta curioso que hagan parte del enfoque de un evento como este, sobre todo en el primer caso que corresponde al 4 por ciento en ambos periódicos, que tiene el pico más alto entre 2004 y 2005 y no cuenta con textos posteriores a esa fecha, justo cuando inició la "transformación" de la ciudad con el gobierno de Sergio Fajardo. El artículo "Silleteros despidieron la feria" de El Tiempo escrito por Margarita Zuluaga el 8 de agosto de 2005 dice "este año la paz fue el tema que predominó en las silletas. Pero también hubo frases alusivas al secuestro y al desplazamiento". En el mismo texto agrega que

"En el desfile de silleteros también hicieron presencia los desmovilizados de las autodefensas, que marcharon con una gigantesca silleta de la Corporación Democracia, la organización que los agrupa en Medellín. Antes del evento aparecieron hombres de ese grupo luciendo brazaletes de los bloques Cacique Nutibara y Héroes de Granada de las Auc (Autodefensas Unidas de Colombia), pero el Ejército y la Policía los retiraron" (Zuluaga, 2005).

En El Colombiano de la misma fecha no hay ninguna noticia sobre este particular episodio, pero sí se destacan las peticiones por la paz del desfile, que ya antes se habían presentado según el diario local y su portada del 12 de agosto de 1984

"También quieren la paz como la totalidad de los colombianos, los silleteros de Antioquia, quieren la paz. El deseo se hizo manifiesto ayer en el XVII desfile floral realizado por la Avenida La Playa. Numerosas silletas fueron diseñadas simbolizando la paz. Pueda ser que ese anhelo se haga realidad. Colombia se lo merece". 


\section{El Colombiano}

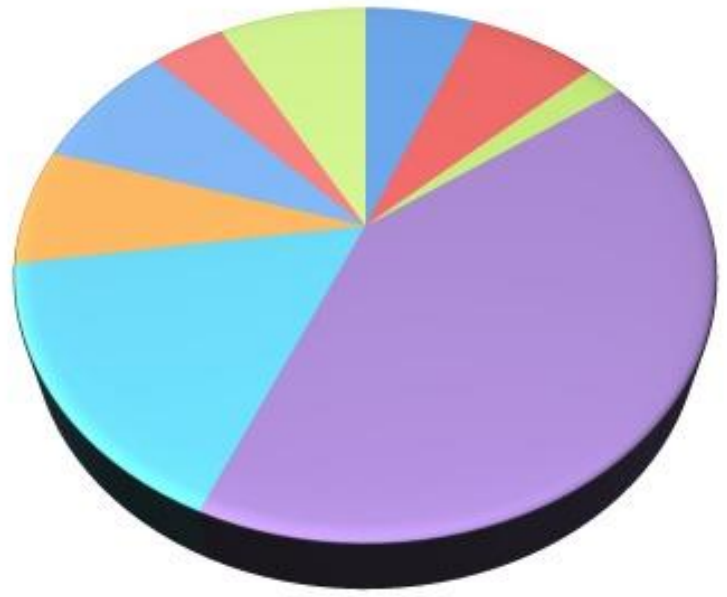

Tradición

Historia

Patrimonio

Desfile

Previa en Santa Elena

Silleteros

Valores paisas

Violencia y paz

Proyección internacional

En cuanto a los cambios que sufrió el tratamiento de la información a lo largo del tiempo es importante anotar algunos puntos: en la medida que los artículos son más cercanos a la actualidad hay menos críticas al desfile como tal, es decir, la organización casi no se discute, los silleteros están muy conformes con el evento y existe un mayor despliegue de los acontecimientos. Todo lo contrario sucede en las décadas de los ochenta y noventa, cuando se encuentran testimonios como el de este silletero que no tiene nombre, "fue muy corto (el desfile) y no se justifica tanto trabajo para tan poco tiempo" dice a El Colombiano el 12 de agosto de 1984, a los que se suman los relatos sobre la crisis de las flores y lo poco rentable que les resulta a los silleteros vivir de su cultivo.
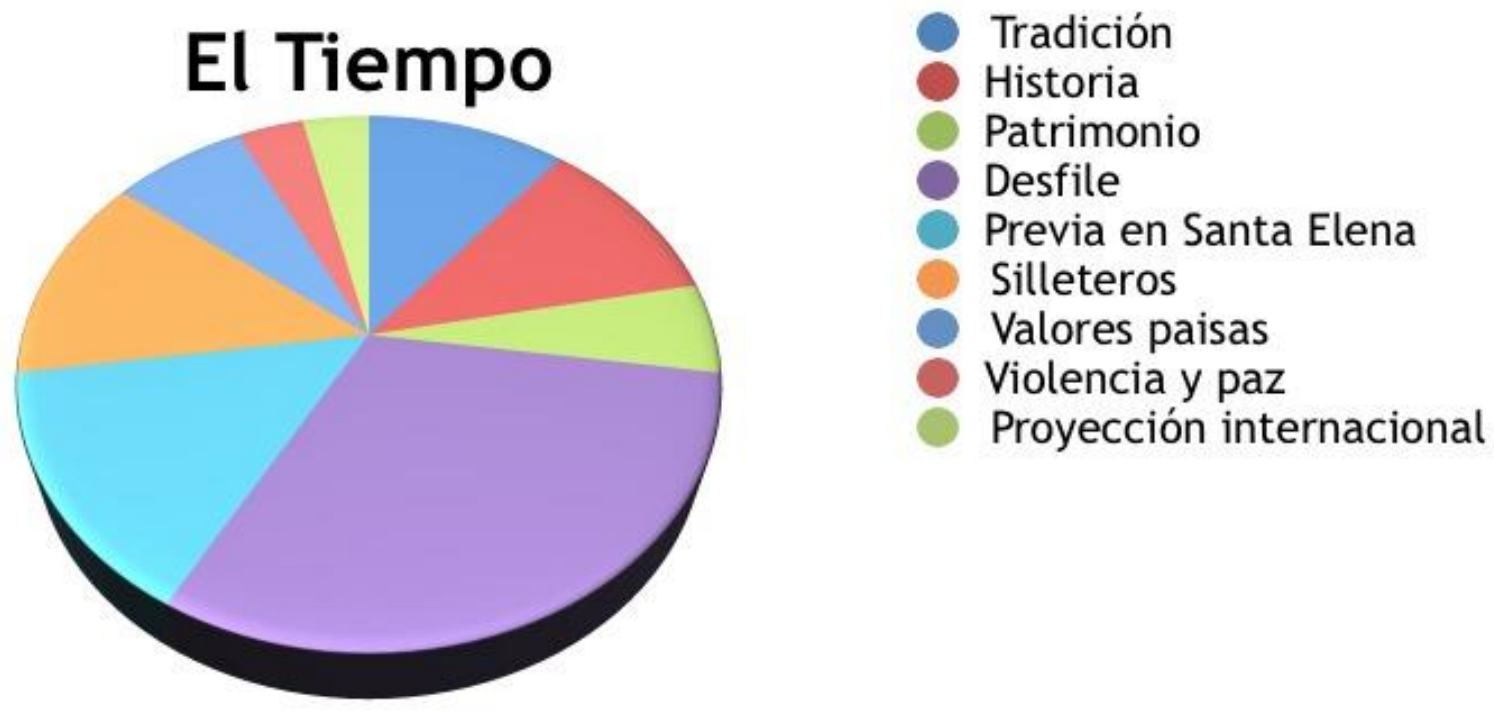
También existe un duro cuestionamiento al desfile como tradicion, pues hay una suerte de creencia de que se pierde la cultura debido al interés económico de la festividad, "expresión fiel de las viejas familias que habitaban el minifundio rural y luego colonizaron el occidente del país, el desfile de silleteros es el resumen de los valores de una época que liquidaron la industria y el comercia a gran escala dando lugar a una nueva sociedad" puede leerse en El Tiempo el 12 de agosto de 1984.

Como ya se pudo comprobar al inicio de este apartado los artículos actuales, que son la mayoría de los que se cuantificaron, suelen destacar la originalidad que tiene el desfile de silleteros en el mundo, la tenacidad de sus protagonistas (los campesinos de Santa Elena), su aporte positivo a Colombia y la diversidad de atracciones que se pueden disfrutar en su corregimiento y en la ciudad durante esta época para atraer turistas. Tal vez esa es la razón por la que el 46 por ciento para El Tiempo y el 57 para El Colombiano del total de las informaciones recogidas se dediquen al desfile y su previa.

Se puede concluir entonces que la prensa también coincide en considerar a los silleteros como un vehículo de paz y una versión positiva de la ciudad, que ya se consolidaba como tal desde los años ochenta; en 2004 empieza a conectarse con el discurso de la "nueva" Medellín que empieza a dejar atrás la violencia, resurge de las difíciles épocas del narcotráfico y muestra su cara amable para contrarestar su pasado de guerra; y en la actualidad hace parte fundamental de la transformación de Medellín como principal representación del pasado que quieren recordar y difundir los medellinenses.

\subsection{La ciudad "que pasó del miedo a la esperanza"14}

Pero dejando atrás su promoción, esta "nueva" Medellín puede verse como el resultado de un proceso iniciado varias décadas atrás y como parte de un proyecto de ciudad moderna y competitiva, frenado en los años ochenta por el auge de la violencia y el narcotráfico, y que empieza a hacerse realidad en la primera década del siglo XXI gracias a la calma de ambos fenómenos con el fin del cartel de Medellín.

Este grupo delincuencial, liderado por el narcotraficante Pablo Escobar y que tuvo como eje de operaciones la capital antioqueña, surgió en medio de una de las crisis sociales y económicas más grandes del departamento, según autores como Gustavo Duncan (2013) y Gustavo Álzate (2014). Aunque la ciudad ya había incursionado en el tráfico de drogas desde los años cincuenta, es gracias a la

"Del miedo a la esperanza" es el título del libro oficial con el que Sergio Fajardo resumió las principales acciones de su administración al finalizarla en 2007 porque "es la esencia de nuestra gestión”, según dijo en la presentación. (Escobar, 2007) 
recesión de sectores como el textil y el petrolero, así como el aumento del contrabando, la crisis económica mundial, la alta demanda estadounidense y las situaciones políticas en los principales países exportadores de droga hasta entonces (Revolución Cubana y dictadura militar en Chile), que Colombia y Medellín empiezan a consolidar su poderío dentro este mercado.

"La historia se inicia con las transformaciones sociales y económicas de Medellín durante la década de los setenta. Era un periodo particularmente difícil. El ideal antioqueño de una sociedad incluyente con alta movilidad social y con una economía capaz de absorber a la población dentro de una apuesta de progreso fundada en el desarrollo industrial estaba agotado (Franco, 2006). La consecuencia social más dramática fue que el aparato productivo tradicional se quedó corto para atender un rápido proceso de urbanización" (Duncan, 2013, p. 245).

Álzate asegura que entre 1977 y 1984 se afianza el negocio y la influencia económica, social y política de los traficantes, con Escobar a la cabeza, a quien se referiré como alguien que "no dudó en combinar las acciones ilegales con las legales, trabajando en conjunto con las figuras públicas de la sociedad medellinense" (p. 57), de manera que menciona sus inversiones en propiedad raíz, comercio, ganadería, construcción, automóviles, banca e industria química, eso sin olvidar su famosa "filantropía", por la que ya empezaba a destacarse al dedicarse a "acciones cívicas y asistencialistas" como Civismo en Marcha y Medellín sin Tugurios, programas destinados a solucionar carencias sociales en las zonas más necesitadas de Medellín con infraestructura pública, vivienda y salud, una estrategia que usó como "medio de cooptación política, legitimación y fortalecimiento de su imagen y poderío" (p. 57).

Pero no solo las clases populares tuvieron fuertes lazos con el narcotráfico, de hecho fue la élite política la que más se benefició de sus recursos, como dice Duncan, "hasta antes del debate de los dineros calientes a finales de agosto de 1983 no existía un rechazo apreciable al tema de la financiación de la política por narcotraficantes" (p. 251). Pero es justo en los ochenta cuando surge una oposición por parte de cierto sector de la sociedad, representado en parte de la prensa, la clase política y otros actores con influencia social, dentro de los que se destacan el diario El Espectador (su sede sufrió un atentado y su director fue asesinado) y el partido político Nuevo Liberalismo (su líder y candidato a la presidencia, Luis Carlos Galán, fue asesinado).

Desde entonces (década del ochenta) empieza la guerra de Escobar contra el estado, que va desde atentados y bombas en vías públicas hasta asesinatos selectivos con el respaldo popular de un ejército de jóvenes sicarios, reclutados en la periferia de Medellín, lucha a la que se suma el conflicto con el Cartel de Cali. 
"Magnicidios de cualquier funcionario o personalidad que amenazara con perseguir a los narcotraficantes, atentados terroristas, secuestros de miembros de las élites bogotanas y el asesinato indiscriminado de policías constituyeron el repertorio militar de Escobar. El estado, pobremente preparado para afrontar el desafío terrorista, planteó su respuesta en base al tratado de extradición con EE.UU. y al fortalecimiento lento pero constante de su aparato policivo" (Duncan, 2013, p. 253).

El fin del Cartel de Medellín y su máximo líder se da gracias a la alianza entre el gobierno y varios enemigos de Escobar (como los hermanos Castaño, fundadores de las Autodefensas Unidas de Colombia), incluidos antiguos socios y una disidencia de su propia organización, para sacarlo del camino, que termina con su muerte el 2 de diciembre de 1993 y que deja a la ciudad a la merced de una nueva estructura criminal, "algunos de estos mismos narcotraficantes y paramilitares asumieron la dominación de las comunidades en que Escobar previamente proveía protección, orden y sustento material” (Duncan, 2013, p. 259).

Con el fantasma del mítico narcotraficante y un orden criminal distinto, menos figurativo, pero bien posicionado al fin de la guerra (sobre el que no se profundizará en este capítulo por desbordar sus propósitos), la ciudad continúa con sus planes de competitividad y avance económico: "el deseo y la urgencia de ser competitivos disponen a nuestros mandatarios para el logro de la meta de una nueva resignificación para la ciudad de Medellín" (Gómez, 2008, p. 8). Esta misma autora se refiere al Plan de Desarrollo de 1985 como el que fija las bases para dar ese nuevo sentido que pretende la capital de Antioquia, pues en él se contemplan obras como la construcción y operación del metro, la puesta en marcha de dos aeropuertos y dos terminales de transporte, un túnel que conecta a Medellín con el Golfo de Urabá, ampliación de infraestructura en telecomunicaciones y la consolidación de La Alpujarra como centro administrativo ${ }^{15}$.

Pero es hasta 1995 en el proyecto Visión 2015, que se habla de una Medellín que "juega" a "construirse sobre sí misma, 'reinventarse', mediante la consolidación, la renovación y el redesarrollo" (Gómez, 2008, p. 8) y en el Plan de Desarrollo de Juan Gómez Martínez (alcalde 1998-2000) que se alude a una "ciudad metropolitana" que sea "el centro logístico y de servicios avanzados de área andina” (Gómez, 2008, p. 9).

15

Antigua zona de Guayaquil, estación del Ferrocarril y mercado principal de la ciudad, que debido a la proliferación de ventas ambulantes, hoteles y bares que recibían a los emigrantes pobres del resto de departamento, empieza un proceso de "regeneración" que expulsa sus frecuentes visitantes marginales y la convierte en el centro del gobierno departamental. 
"La Alpujarra continúa en proceso de renovación, en el análisis se ve aislada, razón para plantear su articulación a la ciudad mediante espacios públicos de calidad. Se propone la creación de parques urbanos y El Centro Internacional de Negocios. El antiguo Guayaquil se presenta como núcleo cultural y plantean recuperar la plaza de Cisneros y su entorno como espacio simbólico" (Gómez, 2008, p. 8).

Como puede verse, desde entonces existe la idea de "transformación" apoyada en diversas acciones urbanas basadas en la infraestructura, la conexión con el mundo y la visión de una ciudad moderna, que poco a poco se fueron consolidando en el futuro y que hoy son el fundamento de la "nueva" Medellín. Con la siguiente alcaldía, la de Luis Pérez (2001-2003) se proyectan otras de las obras con las mismas intenciones:

"La competitividad se refiere a Medellín con el desarrollo más avanzado en telecomunicaciones del país. La agenda de conectividad retoma a Empresas Públicas y los 'call-center' y hacen referencia a Medellín conversando con el mundo. Medellín distrito tecnológico, con base en maquila para empleo. Medellín sin fronteras, a través de redes de ciudad y del Centro Internacional de negocios y convenciones" (Gómez, 2008, p. 9).

Pérez dio un lugar importante a las Empresas Públicas de Medellín ${ }^{16}$, la cual es considerada la principal fuente de recursos para la "transformación" de Medellín, así como al "renacer del centro" con la recuperación de espacios como los antiguos edificios Carré, la habilitación peatonal de la carrera Carabobo y la segunda etapa del Museo de Antioquia, que inició su renovación en 1997 e inauguro en sus afueras la Plaza Botero en 2002, donde se encuentran exhibidas 23 esculturas del artista Fernando Botero al aire libre. La idea era muy similar a la de La Alpujarra en los setenta, pese a que no logró tal magnitud porque todavía es una zona de comercio informal y prostitución, sí creó una sensación de cambio y se convirtió en un espacio atractivo para el turismo y uno de los símbolos importantes de la "nueva" Medellín.

Gómez dice que en la administración de Pérez también hay otras propuestas educativas, culturales y científicas orientadas a la creación o renovación de espacios importantes para la metamorfosis de Medellín como el Parque Explora, el Jardín Botánico y el Planetario, que hacen parte del complejo que hoy es conocido como el "nuevo norte". También una zona marcada por la marginalidad y la inseguridad, que además de los espacios lúdicos y científicos ya citados, hoy en día también cuenta con el Parque de los Deseos, la Casa de la Música, el Centro

Principal poveedora de electricidad, agua y gas de Antioquia, que funciona como empresa privada, pero es propiedad del gobierno departamental. 
Cultural de Moravia y el denominado "distrito de la innovación" con el complejo de Ruta $\mathrm{N}$, que reúne "emprendedores, compañía e instituciones basadas en la economía del conocimiento" según su página oficial http://rutanmedellin.org/.
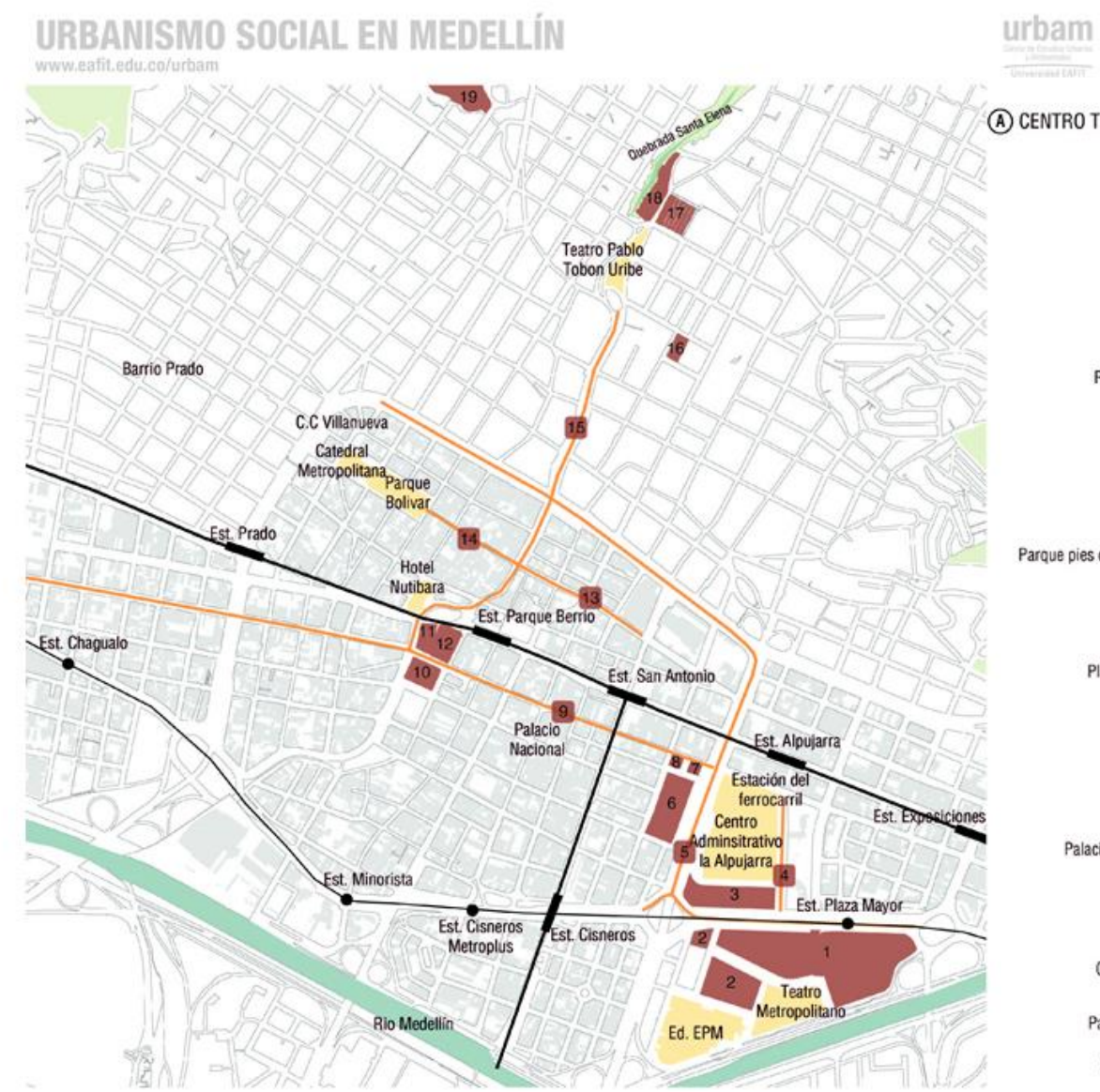

(A) CENTRO TRADICIONAL-ALPUJARRA

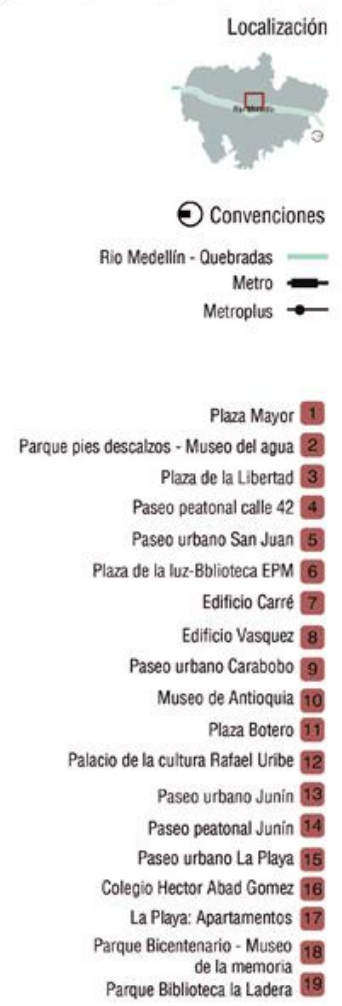

Fuente: Centro de Estudios Urbanos y Ambientales, Universidad Eafit, 2014.

Esto sin olvidar el proyecto de intervención integral de Moravia, que empezó a ejecutarse en 2004, mediante el que se reubicaron miles de familias de esta zona, ante el inminente riesgo que tenían como habitantes del antiguo basurero de la ciudad por "la inestabilidad del suelo, las altas pendientes, la fragilidad de sus construcciones y la presencia de desechos industriales, clínicos, domésticos y la emanación de gases tóxicos y lixiviados" (Montoya, 2011, p. 42). El barrio empezó a formarse en los años sesenta y siguió creciendo después de la clausura del botadero en 1985, como principal destino de desplazados por la violencia o emigrantes del campo a la ciudad por razones económicas, debido a su cercanía a la terminal de transporte, el centro de la ciudad y el área de extracción de materiales del río Medellín.

Después de Pérez llega Fajardo (2004-2007) al poder y con él empiezan la consolidación de varias de las iniciativas ya mencionadas, surgen algunas nuevas 
y se empieza a evidenciar la "nueva" Medellín tal como es reconocida hoy en día, con el urbanismo social como base fundamental. Así que además de los cambios hechos en el centro y en Moravia, empezaron transformaciones en otras cuatro zonas marginales de la ciudad con los denominados Proyectos Urbanos Integrales: en la Comuna 13, la Comuna Nororiental, la Comuna Noroccidental y la

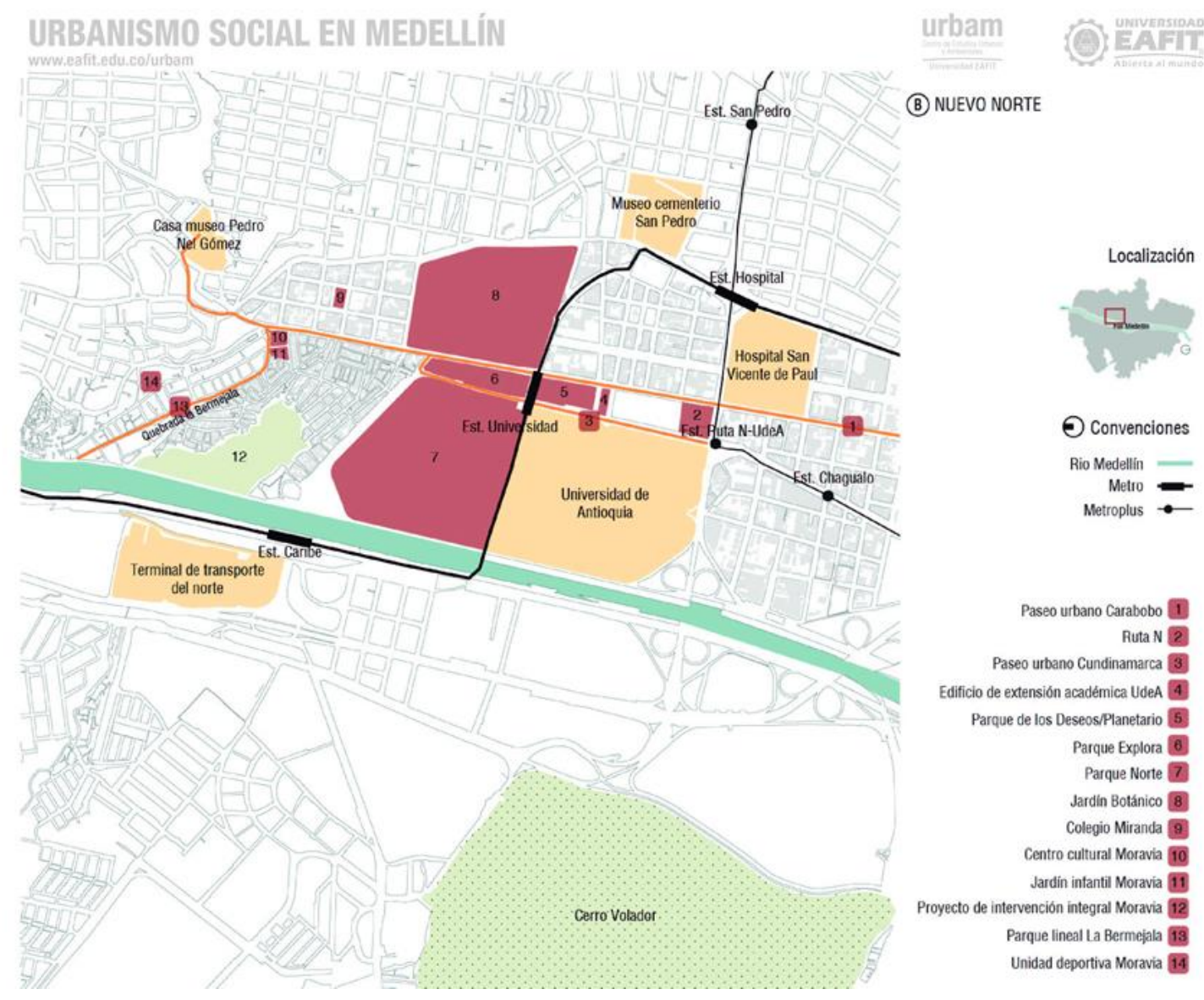

Fuente: Centro de Estudios Urbanos y Ambientales, Universidad Eafit, 2014.

Comuna Centroriental, con los que se mejoró la infraestructura pública, se recuperó el espacio barrial, se construyeron soluciones habitacionales y se conectó a estas zonas, tradicionalmente olvidadas por el estado, con el centro de la ciudad, gracias al regreso de varias instituciones estatales y la mejora de la movilidad.

Otro punto fundamental del urbanismo social ${ }^{17}$ son los parque biblioteca, llamativas estructuras físicas ubicadas en sectores también afectados por la 
violencia y la desigualdad social, que además de un centro cultural se han convertido en el punto de encuentro de la comunidad, gracias a su dotación tecnológica y los programas sociales que ofrecen. En la actualidad son nueve: Parque Biblioteca de Belén (Belén), Parque Biblioteca España (Santo Domingo), Parque Biblioteca León de Greiff (La Ladera), Parque Biblioteca San Javier (San Javier), Parque Biblioteca Tomás Carrasquilla (La Quintana), Parque Biblioteca San Cristóbal (San Cristóbal), Parque Biblioteca San Antonio de Prado (San Antonio de Prado), Parque Biblioteca Manuel Mejía Vallejo (Guayabal) y Parque Biblioteca Doce de Octubre (Doce de Octubre).

También es necesario mencionar la infraestructura vial y el transporte: dos metrocables que unen los barrios populares, ubicados en las laderas, con el centro de la ciudad; un sistema integrado de transporte que amplió la limitada cobertura del metro para llegar a las zonas más alejadas de la ciudad y su área metropolitana; unas escaleras eléctricas que permiten subir la empinada cuesta de la Comuna 13, una de las más golpeadas por la violencia en Medellín; y un sistema de bicicletas público en una ciudad que parece estar diseñada para los vehículos no para los peatones, son algunos de los aspectos destacados que hoy en día hacen a Medellín la ciudad con la mejor movilidad del país.

Así que es posible hablar de una planeación temprana sobre la nueva Medellín, que se vio retrasada tras la violencia, continuó su planeación una vez las condiciones sociales y políticas lo permitieron y empezó a consolidarse a partir de 2004 con Fajardo, a quien la prensa internacional responsabiliza por la "transformación", que consistió en bajar los índices de violencia y promover la seguridad ciudadana, mejorar diferentes espacios físicos de la ciudad, aumentar el presupuesto destinado a la educación y la cultura e incentivar la cultura del emprendimiento, entre otras medidas recopiladas en Medellín, transformación de una ciudad, publicado durante la administración de Salazar (Alcaldía de Medellín, 2008).

Aunque estos últimos párrafos parecen elogiar la labor gubernamental, la idea es dar una visión general de los aspectos más destacados de la "nueva" Medellín y completar el recorrido iniciado en los setenta con el surgimiento del Cartel de

La construcción de espacios y edificios públicos de gran calidad urbanística y arquitectónica, la recuperación de zonas marginales y empobrecidas de la ciudad a través de proyectos urbanos integrales, el mejoramiento de la infraestructura de movilidad Metro, Metrocable, Metroplús-, así como el reordenamiento de avenidas y calles, han sido algunos de los aspectos más visibles de la reciente transformación de Medellín. En los noventa, arquitectos y urbanistas locales configuraron conceptos, propuestas y proyectos que durante las administraciones de Fajardo y Salazar, se consolidaron en una visión integral y audaz de intervenir la ciudad, identificada como urbanismo social. (Alcaldía de Medellín, 2008, p. 107) 
Pablo Escobar, de manera que aparte de la sensación de seguridad, la disminución de asesinatos y delincuencia en la ciudad, también se conozcan de manera breve las principales obras por las que el mundo habla hoy de Medellín, las cuales para esta investigación solo son referencia en la medida que fundamentan el surgimiento de una ciudad renovada, y más que buenas o malas, hacen parte del presente de una Medellín que sigue olvidando su pasado de narcotráfico, así como el de la violencia que también dejó y siguen dejando paramilitares, milicias urbanas, bandas criminales y delincuencia común porque con la muerte del capo no terminaron los problemas de la capital antioqueña. 


\section{Ser silletero}

Si es necesario definir a estos emblemáticos personajes antioqueños, lo más simple es decir que un silletero es aquel encargado de llevar una silleta durante el Desfile principal de la Feria de las Flores que recorre Medellín cada año, aunque en el imaginario popular colombiano es una figura que va más allá de la participación que tienen en la fiesta más famosa de la segunda ciudad del país. Los silleteros más antiguos dicen no haber imaginado hasta dónde llegaría su reconocimiento, y mucho menos que se convertirían en la representación de todo un departamento y una cultura, tal como lo acredita su patrimonialización hace más de una década.

En los inicios eran apenas unas decenas, que hoy se han convertido en centenas, pues cada agosto salen un total de 500 silleteros por las calles de la ciudad cargados con sus adornos florales. Pero ¿quiénes son esos personajes que cada año hacen aplaudir a locales y turistas? La respuesta es extensa, pero se puede empezar diciendo que según la Ley 838 de 2003 son patrimonio cultural de la nación:

"El Congreso de Colombia decreta: declárese como patrimonio cultural de la Nación a los silleteros del corregimiento de Santa Elena, municipio de Medellín, departamento de Antioquia, y a la Feria de las Flores que se celebra en la ciudad de Medellín y se reconoce la especificidad de cultura paisa y antioqueña, a la vez que se le brinda protección a sus diversas expresiones de tradición y cultura" (Congreso de la República de Colombia, 2003).

Con esta declaración el silletero no solo crea y carga silletas, se convierte en un representante de todo un departamento como lo indica el apartado citado anteriormente, así como de todo un país, teniendo en cuenta el carácter nacional que trae consigo la declaratoria según la Ley General de Cultura:

"El patrimonio cultural de la Nación está constituido por todos los bienes materiales, las manifestaciones inmateriales, los productos y las representaciones de la cultura que son expresión de la nacionalidad colombiana, tales como la lengua castellana, las lenguas y dialectos de las comunidades indígenas, negras y creoles, la tradición, el conocimiento ancestral, el paisaje cultural, las costumbres y los hábitos, así como los bienes materiales de naturaleza mueble e inmueble a los que se les atribuye, entre otros, especial interés histórico, artístico, científico, estético o simbólico en ámbitos como el plástico, arquitectónico, urbano, arqueológico, lingüístico, sonoro, musical, audiovisual, fílmico, testimonial, documental, literario, bibliográfico, museológico o antropológico" (Congreso de Colombia, 2008). 
Volviendo a la declaratoria patrimonial, el segundo artículo de la Ley continúa dando nuevos significados a los silleteros, pues reconoce "todas sus expresiones culturales y artísticas como parte integral de la identidad y de la cultura del departamento de Antioquia" y declara a "Santa Elena y a sus habitantes como origen y gestores de la tradición de los silleteros". Así que aparte de relacionarlos directamente con la antioqueñidad, los convierte en iniciadores de la tradición, pese a que incluso la historia oficial de los silleteros se refiere a una costumbre colonial difundida dentro y fuera del país, con lo que puede interpretarse que en este caso más que al hábito de llevar una silleta, se alude al primer desfile en 1957 y lo que puede considerarse la "institucionalización" de una tradición, siguiendo a Eric Hobsbawm y Terence Ranger (2002).

Aquí es necesario detenerse en el concepto de "tradición inventada" usado por este autor para referirse tanto a aquellas tradiciones que fueron "construidas y formalmente instituidas, como aquellas que emergen de un modo difícil de investigar durante un periodo breve y mesurable, quizás durante unos pocos años y se establecen con gran rapidez" (Hobsbawm, \& Ranger, 2002, p.7). Y aunque el propósito de esta investigación y este capítulo no es hablar sobre el desfile como ritual y tradición o hacer referencia a su historia, se hace necesario empezar a tocar el tema debido a su consideración como tradición dentro del contenido de la Ley en cuestión, así como a Santa Elena y sus habitantes como iniciadores de la misma.

El hecho de que el primer desfile de silleteros fuera una iniciativa gubernamental de hace poco más de medio siglo habla de una invención reciente e intencionada, tal como sucede con las celebraciones que usa Hobsbawn como ejemplo de tradiciones inventadas: las establecidas por los gobiernos de la tercera república francesa, el imperio alemán de la época de Guillermo II o los símbolos estadounidenses que construyeron la imagen del "americano" (referente a estadounidense para usar sus propios términos).

Así que es posible empezar a hallar el sentido de esta celebración y su uso dentro de la nueva Medellín como una manera de "inculcar determinados valores o normas de comportamiento por medio de su repetición" (Hobsbawm, \& Ranger, 2002, p.8) o como un fenómeno asociado a la "nación" y los fenómenos vinculados a ella como el nacionalismo, la nación-estado, los símbolos nacionales, las historias y demás (Hobsbawm, \& Ranger, 2002, p. 20), tal como sucede con las tradiciones inventadas. 


\subsection{Tradición heredada}

Así que la legislación colombiana considera a los silleteros de Santa Elena como patrimonio nacional debido a su papel como "portadores de una tradición", por eso vale la pena explorar un poco más las implicaciones de esta consideración para continuar definiéndolos y preguntarse ¿qué se necesita para ser silletero y convertirse en portador de dicha tradición? en principio, el silletero es aquel que desfila cada año cargando su silleta en la Feria de las Flores, para lo cual precisa tener un contrato habilitante con la Alcaldía de Medellín que le permite participar en el evento, de manera que ser habitante de Santa Elena y conocer la técnica de elaboración de la silleta no es suficiente.

Según las normas del desfile, el mencionado contrato se hereda, de manera que cuando un silletero tiene alguna incapacidad o quiere dejar la parada debe traspasarlo a alguno de sus descendientes, con el fin de que continúe el legado familiar. William Londoño, tesorero de la Corporación de Silleteros explica que esta modalidad empezó a implementarse después de unos cinco desfiles para facilitar la participación en dicha actividad, aunque entonces se trataba de una regulación menos estricta a la actual, en la que las normas son claras con respecto a temas como la presentación personal o el consumo de licor durante el desfile.

"Uno desfilaba sin organización y sin contrato, le decían a la gente que si quería ir y le pagaban la silleta sin ninguna negociación. Pero después empezó más reglamentado, no era el contrato técnico como hoy, pero llamaban a los silleteros y les pedían que firmaran formularios o algo así. No había contrato técnico como ahora, pero si había firmas o formularios. Hoy es muy difícil conseguir un contrato porque nadie los quiere soltar. Ya ahora es con toda la técnica y el reglamento. El municipio no crea contratos nuevos, son 420, más niños y junior, suman 500" (Entrevista personal a Londoño, junio 9 de 2012).

El convenio entre silletero y Alcaldía de Medellín consiste en que el contratado elabora la silleta y participa en el desfile, por lo cual recibe un pago de la entidad contratante y concursa por los premios que se entregan al finalizar la actividad en las diferentes categorías existentes.

No está muy claro el momento en el que se iniciaron dichos contratos, ni existe una cronología sobre los cambios o la evolución de ese convenio que actúa como un intermediario entre el gobierno local y los silleteros, pero testimonios sueltos como el del tesorero Londoño o el silletero Héctor de Jesús Ruíz Hernández, muestran diferentes momentos: uno inicial en el que no había ningún compromiso escrito y otro en el que fue necesario empezar a regular el número de 
participantes a medida que crecía el evento, ya fuera para ampliarlo o para limitarlo.

Ruíz Hernández, que tuvo su primer desfile hace 17 años y cuando fue consultado para esta investigación era veedor de la Corporación, recuerda que antes de conseguir su contrato oficial, heredado de su tía, tuvo la posibilidad de participar en el desfile en dos oportunidades gracias a un sorteo que ganó cuando iniciaron las silletas comerciales, que según deja ver, en un principio eran llevadas por los afortunados que el azar seleccionaba.

"Estamos hablando de hace unos 25, 28 años más o menos, en esa época yo insistí mucho en sacar mi contrato con el municipio, no se pudo, y ya me quedé así. En el 86 más o menos me acuerdo que me llamaron para regalar una silleta para la venida del santo padre Juan Pablo II aquí a Medellín. Yo vine, regalé la silleta para llevar al (aeropuerto) Olaya Herrera, en recompensa de eso como a los 20 días me acuerdo [...] me dijeron Héctor vení, entonces yo arrimé y me comentaron, me dijeron, hombre vos querés acompañarnos a un evento, a un desfile de silleteros en Cali [...] al poco tiempo yo empecé con el contrato de mi tía y hoy en día ahí voy en el desfile de silleteros" (Entrevista personal a Ruíz, abril 7 de 2012).

De manera que en teoría los silleteros actuales recibieron el contrato de uno de sus ancestros, pero no siempre ha sido así, pues para formar parte de ese selecto grupo también hay quienes compraron su contrato, aunque es una opción que muy pocos admiten, en especial cuando se trata de compradores. Pero existen vendedores como Sergio Ignacio Rojas, quien asegura que entregó su contrato por dinero debido a la mala remuneración que recibía por parte de los organizadores del desfile.

"Yo cargué silletas por 20 años. El contrato era de mi papá, él me dijo que estaba cansado, después seguí yo y me cansé porque era muy mal remunerada. Salíamos a las 2:00 de la mañana de la casa para después sentarse en la Alpujarra aguantando hambre y calor, para después esperar un desfile a las 4:00 de la tarde, muertos de hambre, de sed, cansados, dormidos, pa después pagarle a uno una chichigua, porque era una chichigua. Después fueron a hablar para que las subieran y subió [...] Yo si me arrepiento un poquito de haber dejado el contrato" (Entrevista personal a Rojas, junio 9 de 2012).

Jhon Londoño, quien alguna vez tuvo el contrato número 1 comenta que es muy popular la venta de contratos, sobre todo teniendo en cuenta la "explotación" que según él sufren los silleteros debido a la baja remuneración de sus creaciones y las pocas posibilidades que tienen quienes por vejez deben dejar de cargar la silleta como es su caso, quien para el momento de la entrevista llevaba cinco años sin desfilar, y en vista de que ninguno de sus 6 hijos quiso continuar siendo 
silletero vendió su contrato a alguien con su mismo apellido, diciendo que era su familiar:

"Los silleteros hoy pueden dejárselo (el contrato) a sus hijos, aunque también hacen contrabando y lo venden particularmente, entonces tiran a vendérselo a alguien que tenga el mismo apellido para que cuando vayan a hacer el contrato digan, vea es que es de la familia mía, es primo o sobrino, sino no se da título de venta, eso lo venden por 4 o 5 millones de pesos, el que me quiera participar". (Entrevista personal a Londoño, agosto 18 de 2012).

Su primo Óscar Londoño, piensa de manera similar en cuanto a la remuneración que reciben los silleteros, en especial teniendo en cuenta la magnitud del evento en la actualidad, pero como fundador que también dice ser (tema que se ampliará a continuación), asegura que existen otras maneras de recompensar a los participantes de la parada, entre los que se cuentan cinco de sus hijos, muchos de ellos ganadores y representantes de la "cultura paisa" fuera de Colombia:

"Hay que entender una cosa, el gobierno o la Alcaldía no es mucho lo que nos gratifica con el desfile de silleteros, lo que nos debieran dar como silleteros porque esto es algo que es mundial ya, pero sin embargo hay muchos silleteros que al final siempre les han dado cosas como viajar a otros países a los ganadores, a Nueva York, Japón, la China, España, y aquí por todas las ciudades de Colombia, que para un campesino no es tan fácil ir, que va a coger e irse un día pa Tokio" (Entrevista personal a Londoño, junio 9 de 2012).

Así que para completar, recuerda como anécdota el viaje de sus hijos a participar en un evento internacional como silleteros:

"Cómo le parece usted uno irse en un avión como el que se fueron Carlos y Raúl que llevaba 400 silleteros después de soltar el azadón, eso es una verraquera, si uno pa ir a Bogotá, no va [...] ahora dígame un campesino en Japón, tomando whisky y durmiendo en plumas y aquí durmiendo en una estera. Y que los campesinos de todas las veredas de Santa Elena son los que hacen ese desfile que hoy es mundial, que no hay médicos o gente que trabaje en las ciudades o universitarios de Medellín, todos montañeros, entonces la situación cambia mucho y es emocionante. como los hijos míos, Raúl y Carlos se fueron diez días para Madrid, España, soltaron el azadón y se fueron por allá, quién no se siente feliz, cualquiera" (Entrevista personal a Londoño, junio 9 de 2012).

\subsection{Fundadores}

Pero no todos los silleteros actuales heredaron o compraron su contrato, pues algunos de los actuales participantes en el desfile de silleteros dicen haber hecho parte del primero de ellos, de manera que han estado en todo el proceso y consiguieron su contrato tan pronto inició la reglamentación del mismo, tal como 
sucedió con Luz Estella Hincapié González de Sánchez de 74 años, quien dice que no ha faltado a ninguna parada desde 1957, cuando desfiló al lado de su esposo Luis Carlos Sánchez.

Esta silletera, que se considera a sí misma como fundadora, recuerda que al principio no tenía contrato, entonces debía ir a la Inspección de Policía para solicitar un permiso y poder salir con su silleta durante la festividad. Pero a su esposo le quitaron el contrato y desde entonces se empeñó en conseguir uno propio, y aunque aclara que "me acuerdo así un poquito porque eso fue hace muchos años" al ser preguntada por los inicios del evento, agrega que "no he dejado de desfilar nunca, nunca" y que "yo no he querido darle a ninguno el contrato".

Como sucede con este testimonio, es muy común que los fundadores se refieran de manera fragmentaria al primer evento, y que expliquen esos vacíos debido a la dificultad de recordar tras tanto tiempo transcurrido. Algo similar ocurre con Carmen Emilia Atehortúa Zapata de 82 años, quien asegura que "yo estuve en el primerito desfile" y que "yo me acuerdo como que no nos pagaron en el primer desfile. Los primeros (organizadores) fue María Eugenia Gómez Sierra y después siguió don Efraín me parece. Éramos como 30 o 40 nada más". Pastora Inés Zapata, "de ochenta y pico" tampoco da mayores detalles, pero insiste en que estuvo "en el festival desde el 54 o 55" y que entonces estaba pequeña, así que su padre, Gregorio Zapata, era quién la llevaba.

Ser "fundador" como se les llama a quienes dicen haber participado del primer desfile tiene un estatus especial, sin importar la diversidad de versiones o la no coincidencia con la historia oficial del desfile, entre otras cosas porque no existe claridad total al respecto todavía, y como se verá más adelante, son varias las versiones alrededor de la parada de 1957 -considerada como la inicial-, las cuales se mencionarán sin ánimo revisionista y como una muestra más de la pluralidad, riqueza y fuerza que tiene la memoria dentro de esta festividad.

El testimonio de Jhon Londoño, otro fundador, confirma este planteamiento, ya que asegura que ponerse de acuerdo respecto a quienes estuvieron o no en el desfile se ha convertido en una dificultad. Cuando han intentado hacerlo el resultado ha sido innumerables listas de nombres de personas que manifiestan haber participado en la parada de 1957, pero que obviamente rebosa las proporciones que tuvo el evento entonces, pues como él dice "todos queremos ser fundadores" y "esa historia del primer desfile de silleteros es muy codiciada":

"La primera empresa que empezó a organizar el desfile fue Fomento y Turismo de Medellín, entonces alguna vez dijo el director que por favor los que fueron fundadores se inscribieran para ir a una reunión y aunque los fundadores fueron 
20, allá aparecieron 100, todos querían ser fundadores. Eso es una historia que nadie la ha podido descubrir, así yo tenga la razón y otros la tengan, Oscar, Leonel y yo estamos seguros que fuimos fundadores, pero los otros no nos han podido creer y otros también dicen que fueron fundadores y tampoco les han podido creer, entonces no se sabe a ciencia cierta quién fue. Nosotros tenemos una lista de los fundadores y hay otros que tienen otra lista". (Entrevista personal a Londoño, junio 7 de 2012).

Para él, además de las ansias de figurar como participante del origen de la parada, también existe una confusión con los participantes del segundo desfile, que asegura fue mucho más publicitado y concurrido, de manera que quienes estuvieron en esa versión también reclaman ser fundadores del evento:

"El segundo desfile fue en Junín con Amador. $Y$ ahí es donde viene que muchos quieren ser fundadores, en ese segundo desfile ya participaron 40 silleteros, entonces ellos ya reclaman ser fundadores, prácticamente que lo son porque fue el segundo, pero ahí confunden el primero con el segundo, pero no les podemos quitar la razón, entonces, el primer desfile fue como muy desapercibido, como sin publicidad, entones la gente que participó en el primero fue casi sin que nadie se diera cuenta, ya el segundo fue más publicitado, más promovido" (Entrevista personal a Londoño, junio 9 de 2012).

Hasta aquí se ha hecho referencia a los silleteros como quienes desfilan en la Feria de las Flores gracias a un contrato con la Alcaldía de Medellín, norma establecida varias décadas atrás para controlar la participación en el evento ante la fuerza y representatividad que ganó con el tiempo. Pero también se han tocado otros temas importantes para continuar indagando alrededor de esta figura: la manera en que se adquiere ese contrato y por lo tanto, se es silletero oficialmente por decirlo así, así como la legitimidad de la condición de "fundador" tan apetecida por quienes desfilan o han desfilado en la fiesta antioqueña.

De manera que a continuación será interesante ver otras maneras de ese ser silletero, determinadas no solo por tener un saber (el de elaborar silletas), vivir en un corregimiento (Santa Elena) o hacer parte de una festividad (el desfile de silleteros) -lo cual solo es posible al tener el mencionado contrato- y así ser considerado heredero de una tradición. Pues existen grupos y prácticas que también ayudan a consolidar esa identidad silletera y van más allá de la oficialidad del desfile, recurriendo a dinámicas que muchas veces apoyan esa visión gubernamental, pero que tras también tienen su propia versión de lo que significa ser portador de esta tradición. 


\subsection{La Corporación de Silleteros}

En 2003 surgió la Corporación de Silleteros de Santa Elena, actual mediadora entre los participantes del desfile y sus organizadores. De ella son miembros los 420 silleteros con contrato que participan en la feria, pues es la entidad encargada de coordinar todas las actividades que tienen que ver con ellos a lo largo del año.

También es una marca registrada ante la Superintendencia de Industria y Comercio desde 2011, inscripción en la que se detalla que es una corporación dedicada al "diseño, producción y venta de silletas (la infantil, la junior, la tradicional, la emblemática, la monumental, la tridimensional, la móvil, la pionera, la gigante) para exhibiciones, ferias y eventos especiales (stands, displays, locales, escenarios)" con diez años de vigencia a partir de la fecha de dicha resolución (Superintendencia de Industria y Comercio, 2011).

Carlos José Atehortúa, presidente de la Corporación de Silleteros explica que la organización surgió por "la necesidad de agruparnos como gremio, primero empezamos como Asociación de Silleteros de Santa Elena y en el 2006 cambiamos de razón de ser a Corporación de Silleteros de Santa Elena". Además explica las principales funciones que tiene el grupo y algunos de los proyectos con los que se han beneficiado sus miembros:

“¿Qué hacemos? nos preocupamos por el bienestar por medio de comisiones de trabajo, tenemos una junta directiva, tenemos unos delegados en las 17 veredas, por medio de esos delegados les llega la comunicación a cada uno de los silleteros de las veredas [...] hemos generado empleo, en este momento tenemos silleteros contratados de tiempo fijo en Comfama (empresa social de carácter privado que administra varios proyectos educativos y culturales de Medellín), en el Parque Arví (reserva ecológica vecina a Santa Elena y atractivo turístico natural de la ciudad) en jardinería por ejemplo. En los eventos de silletas le damos prioridad a los silleteros ganadores del desfile del año anterior, pues tenemos un protocolo de salidas con el cual también generamos bienestar porque los compañeros que salen a representarnos a otras partes aportan el $4 \%$ del valor de la silleta que llevan para ayudarle a los silleteros que ya no participan en el desfile y que son los silleteros más necesitados" (Entrevista personal a Atehortúa, octubre 6 de 2012).

Antes de la creación de esta organización, existía un comité que se reunía una vez al año para preparar el desfile y servir como puente entre contratistas y contratados, pero hace más de once años "decidimos volvernos una empresa" como dice Atehortúa y conformar una agrupación con dichas características, pues según explica, aparte de su puesto como cabeza de la junta directiva, también hay un vicepresidente, un suplente de vicepresidente, una secretaria, un tesorero y un vocal, además de un comité veedor encargado de comprobar las gestiones y 
vigilar la inversión adecuada de los recursos de la entidad. También hay una directora ejecutiva de la parte empresarial y una secretaria que "están constantemente recibiendo los pedidos a salir a representar a los silleteros a nivel nacional o internacional". Y por último, 17 delegados, uno por cada vereda del corregimiento, los cuales están encargados de comunicar a sus colegas silleteros todas las decisiones tomadas por la Corporación y las diferentes actividades programadas.

La Corporación de Silleteros de Santa Elena se define a sí misma como "una organización cultural comunitaria sin fines de lucro que trabaja por el desarrollo de la región y el mejoramiento de la calidad de vida de los silleteros y silleteras asociadas. Al tiempo que promovemos la expresión cultural silletera en la ciudad, el país y el mundo" según puede leerse en su página web oficial.

En el mismo portal pueden encontrarse varios de los proyectos que promueven como las fincas silleteras, con las que buscan que los cultivos de flores tradicionales regresen a las casas de los silleteros y se conviertan en atracciones turísticas para los interesados en conocer dicha cultura; o el festival silletero, que se realiza una vez al mes durante todo el año, con el fin de que quienes visitan la ciudad en épocas lejanas a la Feria de las Flores también tengan la posibilidad de ver cómo se hace una silleta y conocer a los protagonistas del desfile.

De manera que desde este grupo existe toda una apuesta por el turismo como una manera de fortalecer al silletero, divulgar su cultura y lograr una retribución económica por su labor. Y ¿cómo lograr este cometido? Mediante la rememoración de una práctica (elaboración de silletas) que pervive gracias a la festividad que se hace a su alrededor cada año, el desfile de silleteros, de manera que es pertinente volver a Hosbawm y Ranger (2002) para señalar que la tradición inventada implica

“Un grupo de prácticas, normalmente gobernadas por reglas aceptadas abierta o tácitamente y de naturaleza simbólica o ritual, que buscan inculcar determinados valores o normas de comportamiento por medio de su repetición, lo cual implica automáticamente continuidad con el pasado. De hecho, cuando es posible, normalmente intentan conectarse con un pasado histórico que les sea adecuado" (p. 8)

Las fincas silleteras son un ejemplo mediante el cual se pretende que los silleteros vuelvan a cultivar flores en sus casas, una costumbre en desuso debido a la falta de viabilidad económica de esta actividad, tras el surgimiento de métodos más rentables para la producción masiva como el invernadero. Así fue como empezó a parecer irónico que el corregimiento que se hizo famoso por los silleteros no tuviera flores y estos tuvieran que recurrir a las grandes exportadoras para poder 
elaborar sus silletas. De esta manera se planteó esta iniciativa, en la que la siembra de jardines tradicionales se convierte en una práctica que conecta inmediatamente con un pasado conveniente a la cultura silletera y a la promoción turística de la misma.

El tesorero de la Corporación se refiere a las ventajas de este tipo de turismo y la "importante" labor de la organización a la que pertenece para impulsarlo

"Esto ha evolucionado mucho porque se está colaborando mucho para el turismo en Santa Elena, imagínese que el Metrocable está descargando una cantidad de personas en el Parque Arví y en un principio no sabe qué hacer con ellos. Entonces están habiendo unos convenios muy importantes con la Corporación de Silleteros para darle destino a esos turistas, hemos creado unas fincas silleteras para utilizar ese turismo, que esos turistas vayan a las fincas silleteras para mirar cómo es el cultivo de las flores, la papa, la agricultura, todo lo tradicional" (Entrevista personal a Londoño, junio 9 de 2012).

En la actualidad existen 14 fincas silleteras, pero la meta es llegar hasta las 20, con las que se espera elaborar una guía turística especializada para que se conviertan en una ruta importante para los visitantes de la ciudad. Joaquín Emilio Zapata es uno de los silleteros participantes de la iniciativa, él convirtió su casa en una finca silletera y explica el tipo de servicios que brinda, "si quiere venir gente de Medellín, yo les contacto y arreglo la visita. Existen varias opciones: si quieren con refrigerio, con almuerzo o solo quieren ver, todo tiene diferentes precios, yo les cuento sobre la cultura silletera".

Agrega que otras alternativas para quienes van a su casa es que él mismo elabore una silleta, les permita cargarla e incluso que les preste el atuendo para que puedan imitar a un silletero con poncho y carriel, "yo hago que desfilen, les digo ser silletero por un rato. Ellos se amañan y se van contentos", dice, pero eso sí, quien elija encarnar a los protagonistas de la Feria de las Flores deberá "pagar un precio más alto".

Juan Guillermo Londoño es otro dueño de finca silletera, él inició una especie de museo en su casa como un asunto personal, pero cuando su iniciativa se convirtió en algo atractivo para los turistas fue contactado por un operador turístico interesado en llevar visitantes. En la actualidad hace parte de este proyecto y sigue mejorando su finca para hacerla cada vez más interesante, sobre todo para el turismo extranjero, "al de aquí no le llama tanto la atención, no va a pagar por eso y nosotros tenemos unas tarifas, unos pagos porque tener una fincas no es fácil" asegura. En su caso por ejemplo, aparte de los servicios que ofrece como finca silletera, también brinda la posibilidad de hacer eventos como reuniones o celebraciones familiares o empresariales. 
Otro proyecto que realiza la Corporación de Silleteros es el festival de la silleta, que inició en 2011 como parte de un acuerdo del Concejo Municipal para crear una vitrina turística que prolongara la creación de silletas más allá de su preparación para el evento principal de la Feria de las Flores. Se trata de un día dedicado a diferentes actividades culturales, que se realiza el primer sábado de cada mes, con una programación que incluye música, danza, alguna anécdota o historia de los protagonistas del desfile y la elaboración pública de una silleta. Es una actividad creada especialmente para quien visita Medellín eventualmente, no puede estar en la ciudad en agosto o quiere revivir más de una vez esta tradición, al tiempo que busca convertirse en apoyo económico para los silleteros, pues algunos cuentan con puestos de ventas en los que ofrecen flores y hortalizas, además quien hace la silleta en público recibe una retribución por la misma.

\subsection{Otras corporaciones}

Pero al margen de la que se puede considerar la corporación "oficial" debido a su papel como intermediaria de la actividad más importante para los silleteros, existen otros cuatro grupos con objetivos similares: la Corporación Familia Londoño Londoño, Flores del Silletero, Corporación Internacional de Silleteros y Corporación Camino del Silletero.

La primera está formada por una familia tal como lo indica su nombre, los Londoño, uno de los apellidos emblemáticos de los silleteros y tiene unos propósitos muy similares a los de la Corporación de Silleteros: "potencializar la proyección del patrimonio y el entorno de los silleteros y silleteras en el ámbito local, regional nacional e internacional", según lo indica en su página web oficial, donde también se hace referencia a la historia de la familia Londoño dentro de la cultura silletera y la califica como una de las más reconocidas de la región

"Gracias al éxito de sus silletas emblemáticas, e innovador desde hace dos años con el movimiento artesanal [...] descendientes de silleteros fundadores del desfile, que han continuado la tradición familiar por generaciones. Para esta familia, el desfile de silleteros representa una oportunidad de retomar los conocimientos adquiridos por sus antepasados y, con mucha creatividad, aplicarlos en la creación de silletas emblemáticas, su categoría preferida" (http://silleteros.blogspot.com/).

La Corporación Familia Londoño Londoño fue una de las pioneras en el tema de las fincas silleteras, así como de una serie de actividades entre las que se cuentan la semana santa y la Navidad silletera, épocas en las que existen llamativas celebraciones que atraen turistas e incluyen silleteros que no pueden participar en el desfile, un primer indicio de que también son cosiderados como parte de esta cultura aquellas personas que no hacen parte de la parada por no contar con un contrato, pero que son habitantes de Santa Elena y han crecido dentro de dicha 
tradición. Carmen Londoño, representante legal de este grupo, se refiere a este tema durante la transmisión del desfile de silleteros 2012

"Nuestros visitantes puedan llegar a Santa Elena en cualquier época del año, no solamente en el marco de la feria de las flores, sino en semana santa, en la Navidad, o cuando tengan turistas que lleguen a nivel nacional e internacional los podamos atender en nuestra casa, entonces hacemos este trabajo, fuera de eso atendemos a nuestros turistas internacionales en tres idiomas, en inglés, en francés y en italiano" (Entrevista a Londoño durante transmisión en vivo del Desfile de Silleteros, 2012).

De manera que frente esa posibilidad de participar en eventos alternos al calendario de la Feria de las Flores a todos aquellos "silleteros" que no hacen parte del desfile dada por este grupo, se puede pensar en un nuevo elemento para esa definición que se viene rastreando en este capítulo, una consideración con la que ya no sería necesario tener un contrato para hacer parte de la cultura silletera, pues la misma Carmen asegura que "todos los habitantes de Santa Elena somos silleteros, no solo los adultos, jóvenes y niños que desfilan aquí, todos somos silleteros, somos patrimonio cultural de la nación".

Además enfatiza en la necesidad que tiene el silletero de hoy por demostrar sus capacidades y terminar con estereotipos, que ellos mismos continúan consolidando según el testimonio del fundador Óscar Londoño citado anteriormente, en el que habla del campesino con una sensación de falta de mundo y poca educación, con lo que es interesante ver ese contraste de características atribuidas a estos personajes, la manera en que van cambiando a lo largo del tiempo y se promueven desde diferentes ámbitos.

"Nuestros silleteros en este momento académicamente van adelante porque ellos no quieren seguir cargando con el que campesino es sinónimo de ignorante, no, somos unos hombres y mujeres echados para adelante, con grandes fortalezas, con grandes atributos y con una gran dedicación por esta cultura silletera" (Entrevista a Londoño durante transmisión en vivo del Desfile de Silleteros, 2012).

Continuando con las demás organizaciones, la Corporación Flores del Silletero, por su parte, además de varios aspectos también mencionados por los grupos ya citados, dice enfocarse en el ecoturismo en Santa Elena y ofrecer diferentes paquetes para que los visitantes puedan

"encontrar jardines de antaño, interactuar con los silleteros y aprender a elaborar una silleta, tener la oportunidad de ver muestras folclóricas, artesanías y obras de arte alusivas todas a los silleteros y a sus tradiciones" [...] "pretendemos ser líder en la prestación de servicios turísticos en el corregimiento de Santa Elena [...] 
aprovechando nuestros conocimientos ancestrales de la región y propugnando siempre la biodiversidad de la misma" (http://www.floresdelsilletero.com/).

Asimismo incluye música y gastronomía local, lo que suma un total de cinco horas de un "inolvidable recorrido" como lo aseguran ellos mismos.

Propósitos similares tiene la Corporación Internacional de Silleteros por el Mundo, la cual se dedica a la elaboración de silletas, carrozas, arreglos, decoración y eventos, así como la Corporación Caminos del Silletero, que realiza rutas silleteras y actividades educativas como el aula ambiental mariposas, flores y colores.

La investigadora Marta Peláez se refiere a la Corporación Londoño Londoño y a Flores del Silletero como surgidas al interior de algunas familias para generar recursos para ellas. También manifiesta que ambas hacen parte de la Corporación de Silleteros, pero que "a veces chocan con ella" (Peláez, 2012, p. 105).

Para concluir este apartado se puede decir que estos grupos surgidos como corporaciones alrededor de la cultura silletera pueden influir directamente en la definición de silletero en la que se está indagando, ya sea para consolidar la versión oficial gubernamental según la cual es necesario tener un contrato para hacer parte de esta tradición, como sucede con la Corporación de Silleteros, única encargada de intermediar entre los participantes del desfile y sus organizadores, o para ampliar el mismo concepto con actividades como las de la Corporación Familia Londoño Londoño, en las que se considera como silleteros a personas que si bien no tienen la posibilidad de estar en la parada de la Feria de las Flores por no contar con el mencionado convenio, sí tienen la habilidad de hacer silletas y han crecido en dicha cultura gracias a su pertenencia a la zona, llegando a una concepción tan amplia que al hablar de silleteros incluye a "todos los habitantes" del corregimiento.

\subsection{Así se ven ellos mismos}

Así que tras estas aproximaciones a lo que significa ser silletero, no puede dejarse por fuera la concepción que los protagonistas de esta investigación tienen de sí mismos y de su tradición, por eso la última parte de este capítulo se dedica a reproducir varios testimonios al respecto y seguir explorando el concepto a partir de su visión, extraída ya sea del trabajo de campo de este trabajo o de los medios de comunicación que han dedicado gran parte de su sección de cultura y entretenimiento para hablar de estos personajes.

Cada año, periódicos, radios y noticieros de televisión dedican más de un titular al evento más esperado de la Feria de las Flores y a sus protagonistas principales, los silleteros, al punto que constituyen un $13 \%$ de la información publicada en el diario El Tiempo y un $7 \%$ en El Colombiano, la mayoría enfocada en demostrar el lado humano de la fiesta y destacar las familias y personas que están detrás de la silleta y mantienen vivo el legado de sus antepasados. 
Dentro de estos contenidos, también es muy importante la relación que hacen con los rasgos propios de la identidad antioqueño, que podrán explorarse de manera más detenida en un capítulo posterior, pero que ya el antropólogo Bolívar (2001) adelanta: "el oficio del silletero va ligado a un descomunal esfuerzo humano por superar los escollos de la naturaleza. Precisamente ahí radica su función original, la que cimentará uno de los rasgos más notorios de la cultura antioqueña: la necesidad ante los desafíos del medio" (p. 15).

El periódico universitario de la Urbe por ejemplo, dice a propósito de la confirmación como patrimonio cultural en 2014 que:

"Los silleteros se definen a ellos mismos como campesinos, comercializadores y artistas de Santa Elena que han hecho de la silleta y de las flores un patrimonio. Ser silletero es pertenecer a una tradición familiar propia de este territorio que se expresa a través de un oficio que se encuentra en tránsito entre lo campesino y lo artístico, y cuyo elemento diferenciador es el uso de la silleta y de las flores" (Ortiz, 2014)

El mismo medio cita a continuación una entrevista con el presidente de la corporación, en la que explica la razón por la que el silletero es patrimonio:

"Somos una representación cultural de lo que ha existido en la historia de nuestro corregimiento, nosotros estamos trayendo y recordando toda esa historia, ese legado de nuestros abuelos. Ellos jamás se imaginaron la importancia que íbamos a tener. Nosotros lo que estamos haciendo es tratar de conservar esa historia" (Ortiz, 2014)

Como él, ellos mismos tienen su opinión sobre el ser silletero y la importancia que ello tiene dentro de la cultura antioqueña, tal como lo dice a su manera el silletero y tesorero de la Corporación de Silleteros de Santa Elena William Londoño, quien dice sentirse muy orgulloso de haber recibido esta herencia de sus antepasados:

"Es muy emocionante salir al desfile, nosotros ya nacimos con esa tradición, nos gusta mucho los aplausos de la gente, somos muy valorados y el silletero en sí lo respetan mucho y es muy apetecido no solo en Medellín y Colombia, sino en el exterior" [...] "me ha gustado mucho, respetan mucho al silletero y se siente uno con la piel de gallina cuando le aplauden, estar con tanto público" (Entrevista personal a Londoño, junio 9 de 2012).

Joaquín Emilio Zapata, quien también tiene otros tres hermanos silleteros, describe lo que significa para él ser silletero:

"Es una felicidad muy grande, para mí ser silletero es lo más lindo de mi vida, es la alegría, eso estar entre 500 silleteros y que la gente lo aplauda, cuando le saben el nombre a uno que le gritan [...] y uno es feliz de la vida y la vuelta, uno se siente muy contento. Ahorita cuando nos sacan fuera de Medellín una alegría porque es un paseíto. En Bogotá y Cali me ha tocado nada más" (Entrevista personal a Zapata, abril 7 de 2012) 
Nelson Enrique Zapata Grajales por su parte, cuenta que el resto del año debe trabajar en oficios varios y que por ejemplo en este momento es jardinero en una finca, pero que ser silletero es uno de los puntos más importantes de su vida, por eso manifiesta lo mucho que disfruta desfilar cada agosto:

"Mi experiencia como silletero empezó cuando eran mi mamá y mi papá cuando era pequeño, ellos eran silleteros y nos dejaban. Oficialmente llevo 15 años como silletero. Yo empecé a los 23 como silletero oficial. Para mí se convirtió en una obsesión, un hobbie" [...] "Uno se siente agotado, super super agotado, pero los aplausos, no hay mejor aliciente que los aplausos para uno. La vuelta, la vuelta, uno siente que esa silleta se le aliviana" (Entrevista personal a Zapata, abril 7 de 2012).

Así que ser silletero no es tan simple como haber nacido en Santa Elena y tener un contrato con la Alcaldía de Medellín, implica hacer parte de una cultura, sentirse heredero de una tradición y contar con el respaldo de una colectividad, así que es un tema tan interesante y hasta cierto punto tan flexible, que contar con ese el título oficial ante una institución a veces no es necesario y otras tantas no es suficiente, pero lo que no hay perder de vista es que los protagonistas principales del desfile tienen una connotación cultural básica para los antioqueños -un asunto que será tratado más adelante, y del cual se parte para construir y justificar la transformación de Medellín- y que al tiempo que se define a partir de los factores mencionados, es fundamental para la identidad paisa. 


\section{Cuando pasa un silletero es Antioquia la que pasa}

"Existe un mito sobre la raza antioqueña, que eclécticamente mezcla historia regional, literatura, geografía, antropología, leyendas folclóricas, sociología, economía y psicología, para argumentar que los antioqueños forman una raza específica, una cultura distinta y probablemente una gente superior en Colombia" (Twinam, 1982, p. 8)

"Nosotros representamos a Antioquia, toda la vida hemos representado a Antioquia y somos antioqueños y ser silletero es una representación que hacemos de toda Colombia"

(entrevista al silletero Joaquín Emilio Zapata, abril 7 de 2012)

Pensar en las tradiciones de Antioquia significa remitirse a silleteros y a flores, a Santa Elena y a silletas, y solo hay que releer la Ley que declaró a los protagonistas de la fiesta más popular del departamento como patrimonio cultural de la nación para comprobarlo: "se les reconoce la especificidad de cultura paisa y antioqueña, a la vez que se le brinda protección a sus diversas expresiones de tradición y cultura", dice el artículo primero, mientras que el segundo propone "[...] reconózcaseles en todas sus expresiones culturales y artísticas como parte integral de la identidad y de la cultura del departamento de Antioquia" (Congreso de la República de Colombia, 2003).

Por eso, este capítulo pretende explorar la definición de "cultura paisa y antioqueña" a la que se refiere la declaratoria y la manera en que dicha cultura convierte al silletero en su representante, tal como sucede con el famoso lema "Cuando pasa un silletero es Antioquia la que pasa". La idea es hacer un recorrido a través de la identidad regional, que inicia con un arquetipo creado por las élites antioqueñas en el siglo XIX, arraigado fuertemente en las clases populares y tan presente en la actualidad, que el cargador de flores de Medellín sigue siendo uno de los símbolos de la ciudad, un recuerdo idílico que combina muy bien con el pasado que pretende recordar la urbe moderna e innovadora que se proyecta hoy.

De hecho hay quien explica la "transformación" de Medellín con dicho estereotipo, el cual se basa en la existencia de una "raza" antioqueña, que tiene unas características especiales, se supone descendiente de judíos ${ }^{18}$, vascos y

18 María Teresa Arcila (1994) se refiere a las favorables condiciones económicas del siglo XIX en Antioquia, las cuales "condujeron a la élite a un proceso de diferenciación e identidad" como la época en la que surgió el mito del "origen judío de los antioqueños", también asociado a la manera en qué extendieron sus negocios a lo largo del país y en diferentes sectores (p. 110). Al mismo tiempo, Beatriz Nates Cruz (2009, p. 282) alude a la manera en que la cultura "paisa" maneja su mundo a partir de "pedagogías sociales ", entre las que incluye una ascendencia que proviene exclusivamente de judíos 
catalanes, y ha creado una cultura política y económica única que algunos han llamado "corporativismo católico ${ }^{19 "}$ :

"The second resource that the city draws on is a unique political and economic culture, which some have called 'Catholic corporatism'. Whether because of the character of early waves of immigrants (often Jesuits and Basques), the fact that it sits in an isolated valley in one of South America's most mountainous regions or the eternal competition with Bogotá, the country's capital, Medellín's elites have long collaborated to make their city thrive" (Redacción Américas, 2014).

Trabajadores, creativos, honestos, buenos para los negocios y aventureros, estas son algunas de esas cualidades atribuidas por el imaginario popular al antioqueño o paisa, como también se llama a los habitantes de esta región, una idea construida entre manuales escolares, literatura, música y pintura, gracias a la cual

(sefarditas), catalanes y vascos, haciendo énfasis especial en los primeros, pues "la idea de alejarse de cualquier origen indígena y acercarse al 'ser judío' ha calado de tal forma que hasta un Presidente de la República defendía dicha idea como beneficiosa hasta para la economía. La investigadora cita el texto en el que se ha basado el ex gobernante "[...] el profesor Millward \{Russell Hasting Millward\} dice que en Colombia encontró una tribu con dos millones de habitantes y llevan el nombre de antioqueños. Este nombre dice, se deriva de la ciudad bíblica de Antioquia. La tribu tiene muchas palabras que parecen venir del hebreo [...]" (Jaramillo Salazar y Grupo de Investigación Territorialidades, 2004, 66).

19 Ann Farnsworth-Alvear (2000) se refiere al desarrollo de un modelo "fordista católico" (como lo traduce Mauricio Archila) en la industria textil antioqueña durante la primera mitad del siglo $X X$, basado en un sistema paternalista, en el que "el catolicismo, la moral sexual, y el ideal de la familia patriarcal se unieron al anticomunismo y la disciplina en el trabajo en la fábrica de Medellín" (p. 148). También se refiere a la "raza antioqueña", sus características y la manera en que todavía en los años sesenta, estas teorías explicaban el "inusual desarrollo de la región" gracias a la "los rasgos psicológicos heredados predispuestos antioqueños a valor trabajo duro y el espíritu empresarial" (p. 44), así como a las investigaciones que cuestionaron esta postura, y como ella, relacionaron la industrualización regional con la apertura de nuevos mercados para la economía local y nacional. De manera similar, Luz Gabriela Arango (1991) se refiere al "paternalismo cristiano", en el que "la gran industria textilera antioqueña utiliza mecanismos de control de la fuerza de trabajo que combinan formas similares a las implementadas por algunos sectores de la gran industria europea en el siglo XIX, de los cuales tal vez uno de los más parecidos es la industria textilera del Norte de Francia" (p. 41), de manera que una combinación de "paternalismo y religiosidad se asocian para asegurar un control total sobre los trabajadores, dentro y fuera de la empresa"(p. 42). 
se consolidó un discurso de "superioridad racial", muy útil a la hora de justificar determinadas maniobras sociales y políticas como la colonización antioqueña.

\subsection{El "proyecto civilizador" de la élite antioqueña}

"Los latinoamericanos han usado la raza para justificar la transferencia de recursos de manos de los pobres a manos de aquellos con mayores inclinaciones comerciales"

(Appelbaum, 2007)

La segunda mitad del siglo XIX es un momento clave para la formación de las identidades en América Latina, las nuevas repúblicas empiezan a buscar sus símbolos, y lo hacen dando continuidad a los discursos de superioridad racial blanca basados en las concepciones europeas de cultura y progreso, acorde a su reciente pasado colonial. En el caso colombiano la regionalización es la idea con la que los sectores hegemónicos ajustaron la nación emergente al modelo político más viable para ellos: "el definir a Colombia como un 'país de regiones' sirvió a los constructores de nación del siglo XIX para poder comprender y organizar una población diversa y dispersa, que no se ajustaba a la visión idealizada de una nación moderna racialmente unificada" (Appelbaum, 2007, p. 296).

Y esas "regiones" fueron creadas sobre la base de un elemento clave, que dejó una profunda huella en la sociedad colombiana y sigue presente en el actual país: la noción de "raza", que las homogeneizó, al tiempo que jerarquizó unas sobre otras.

"Colombia es un país altamente regionalizado, y por razones históricas la raza también tiene una dimensión regional. Existen oposiciones entre las costas 'negras', el interior 'blanco-mestizo' y las tierras bajas amazónicas 'indígenas', y estas categorías amplias e incluyentes son usadas en un nivel muy general: de la raza se habla con frecuencia en voz locativa, por así decirlo, y esto es porque las identidades raciales son ampliamente regionalizadas" (Wade, 1997, 88).

"No todas las regiones fueron creadas iguales. La jerarquía racial era evidente en este ordenamiento geográfico. Los tipos raciales acordados para definir la nación colombiana estaban en sí mismos cargados de los estereotipos de un mundo moderno que valoraba la piel clara y la cultura europea" (Appelbaum, 2007, p. 297).

El término raza ya se usaba entonces en la antropología occidental de la época, a la que recurrieron los gobiernos imperialistas europeos para justificar sus empresas colonialistas con planteamientos como los de Gustave Le Bon en Las leyes psicológicas de la evolución de los pueblos, donde asegura que "no son las fronteras, sino la raza, lo que importa" (Escobar, 2009, p. 235) haciendo referencia a la superioridad de la "raza blanca europea". Por eso, en ese momento en 
Colombia, como en Europa y el resto de América Latina, raza es sinónimo de "casta (como la raza del ganado)", de "linaje o estirpe" (Appelbaum, 2007, p. 27) y al igual que en el viejo continente se recurrió a dicho concepto como excusa para invadir tierras africanas, asiáticas o americanas, en sus antiguas colonias al otro lado del Atlántico se usó también para "justificar la transferencia de recursos de manos de los pobres a manos de aquellos con mayores inclinaciones comerciales" (p. 27).

En un país regionalizado y con estas ideas fue fácil concebir y promover un concepto de "raza antioqueña", difundido hábilmente por los intelectuales locales y sus redes en el mundo, adaptado sin problemas por los habitantes de la Antioquia de entonces y que sigue tan arraigado en las calles de Medellín y los pueblos del departamento, que todavía es usado por los ciudadanos comunes, puede leerse en los titulares de los periódicos y escucharse en los discursos de algunos políticos.

Juan Camilo Escobar sostiene que esta idea se construyó durante la segunda mitad del siglo XIX y las dos primeras décadas del XX, una época en la que Antioquia se encontraba en plena expansión económica y social, "sus élites tenían los bolsillos llenos y se estaban apropiando las ideas de "progreso y civilización"” $(2009,69)$, y aunque acepta que muchas veces el concepto de "raza" fue usado como sinónimo de "pueblo" o "grupo", también asegura que no "perdió la carga semántica que le otorgaba la clasificación en 'razas superiores' y 'razas inferiores' establecido con esmero por la antropología occidental del siglo XIX” (p. 231).

"Los colombianos utilizaban 'raza' para referirse al lugar de origen. Sus nociones de raza orientadas al territorio mezclaban con libertad el linaje, la biología, el clima y la cultura. Para promover sus respectivas causas, continuaron utilizando el discurso del siglo XIX sobre razas locales y regionales, con sus familiares metáforas genealógicas y alusivas a la familia. Pero también fueron influidos por los discursos internacionales que definían las razas humanas fenotípica y genéticamente y hacian referencia a la superioridad racial de los europeos blancos sobre otras razas" (Appelbaum, 2007, p. 238).

Escobar (2004) explica que las élites antioqueñas esbozaron un "proyecto civilizador", influido por su contacto con Europa, con el que buscaban el "progreso" para Antioquia teniendo referentes como "orígenes castellanos", "cepa pura" y "pueblo cristiano", lo cual "comprendía a su vez un gran arsenal de conceptos y nociones por ejemplo, las de amistad, solidaridad y confraternidad; las de pueblo, patria y nación; las de ciencia, verdad y fe; las de 'razas superiores e inferiores', y las mencionadas antes de 'progreso' y ‘civilización'” (p. 137). 
Todo esto tenía una doble intención: "hacia adentro para regular los comportamientos de la población con el fin de acomodarlos a una moral del carácter modernizante pero conservadora y hacia afuera para justificar el dominio económico de las élites de Antioquia en el país" (Escobar, 2009, p. 236).

Para esto recurrieron a una serie de publicaciones y recursos en todos los ámbitos a los que tenían acceso, que iban desde ensayos, novelas, poemas, pinturas y canciones, hasta tratados "científicos", tertulias académicas y manuales escolares con los que "se inventaba un pasado y se creaba un imaginario de identidad" (Escobar, 2009, 64). Tras relacionarse con las sociedades científicas europeas, en especial las francesas, los intelectuales antioqueños escribían sus ediciones, las ponían a circular entre sus colegas, quienes a su vez las citaban y hacían sus propias versiones. De esta manera obras como La raza antioqueña (1910) de Libardo López y Las genealogías de Antioquia y Caldas (1911 y reeditado en 1932) de Gabriel Arango Mejía, empezaron a consolidar una idea de la sociedad de este departamento que persiste hasta hoy, lo cual resulta bastante anacrónico para una ciudad moderna como la "nueva Medellín", pues López por ejemplo evoca los postulados de Le Bon sobre la existencia de una raza superior, al asegurar que "hay un lugar en la América Latina en la que existe esa roca ideal de una raza superior, y ese lugar es Antioquia" (López en Escobar, 2009, p. 235).

Pero ¿cuáles son las características de la "raza antioqueña" que la hacen ser "superior" en el mismo sentido que la "raza anglo-americana" a la que se refiere Le Bon?: "una suma de voluntades, una energía indomable, una gran iniciativa, un dominio absoluto sobre sí, un sentimiento de independencia llevado hasta la insociabilidad excesiva, una actividad poderosa, sentimientos religiosos muy vivos, moralidad fija, idea clara del deber" (Escobar, 2009, p. 235).

¿Por qué la élite promueve esta idea? en Antioquia, además de los procesos nacionalistas latinoamericanos y europeos, también existe un interés especial por cambiar la imagen de la provincia, que no siempre fue tan buena, según lo insinúa Escobar al mencionar que la historiografía colombiana se olvidó de Antioquia en el siglo XVIII y tal como lo explica María Teresa Arcila (1994) al referirse a la manera en que el oidor español Juan Antonio Mon y Velarde dictó una serie de ordenanzas para poner orden en esta "caótica" región.

La antropóloga define la identidad desde lo ideológico, como una imposición de la clase dominante, que tiene la necesidad de dar unas pautas de comportamiento conforme a sus intereses. A partir de este concepto es posible comprender el tipo de fuentes y la clase social que se dedicó a estudiar Arcila para llegar a una conclusión evidente en su trabajo, aunque no escrita abiertamente: la élite antioqueña quiso dejar atrás la región pobre y poco trabajadora de la Colonia y 
promover una provincia apta para el comercio y la producción agrícola, basada en la laboriosidad y demás valores positivos de sus pobladores a través de diversas estrategias como sus propios textos y los de los viajeros que traían o invitaban, como ya lo señaló Escobar. Lo más claro es que lograron sus objetivos.

Después de su visita a Antioquia entre 1785 y 1788, el enviado de la corona española, deja una serie de disposiciones legales para superar la crisis de la provincia, que para él estaba estancada, en un estado de abandono, "holgazanería y vicio", a los que atribuyó las condiciones del territorio, muchas de ellas explicadas según Arcila por las costumbres mineras, base económica de la Antioquia de entonces. Las medidas que se tomaron estuvieron orientadas al castigo del "no trabajo" y a fortalecer la agricultura y apertura de caminos (Arcila, 1994).

Las ordenanzas del visitador real fueron la primera arma ideológica de las clases dominantes coloniales que se puso en movimiento en Antioquia, con el fin de promover en la población una actitud afecta al trabajo. Posteriormente durante la época republicana, se recogieron los ejemplos y enseñanzas dejadas por Mon y Velarde (Arcila, 1994, p. 106).

Cuando a mediados del siglo XIX los antioqueños tuvieron la posibilidad de hacer industria gracias al buen momento de su economía, en parte basada en la minería todavía, empezó a consolidarse la imagen de habilidad para los negocios sumada a la del "muy trabajador" que continuó reforzándose, por eso muchas de las características atribuidas a la imagen del antioqueño deben buscarse en el ascenso económico (Arcila, 1994).

Arcila también habla de una narrativa de la identidad denominada elogio de la dificultad, que explica como parte fundamental del antioqueño, con unas nociones básicas citadas a continuación, también promovida y consolidada a partir de intelectuales de la época, entre los que Escobar señala por ejemplo a Tulio Ospina, quien decía que el "espíritu digno e independiente de los montañeses" que tenían los antioqueños se debía a su origen vasco:

"En Antioquia la subsistencia se produce en medio de unas condiciones naturales difíciles y adversas, a través del trabajo los hombres despliegan un esfuerzo denodado de lucha contra esas condiciones naturales, que se concibe como una lucha entre civilización y barbarie, la que culmina con el triunfo del hombre, materializado en la riqueza y prosperidad de la región y en cuyo proceso se fueron forjando el carácter y las principales cualidades colectivas del pueblo antioqueño: tenacidad y emprendimiento" (Arcila, 1986, p. 53). 
Todas estas características pueden rastrearse en las pinturas de Antonio Cano, los poemas de Gregorio Gutiérrez o los textos del político Antonio José Restrepo, tres personajes que hicieron parte del movimiento que resaltó las cualidades del antioqueño, pero también de otros académicos que trataron de demostrar "científicamente" tales particularidades como los ya mencionados López y Arango, y a quienes se les pueden sumar muchos otros reconocidos médicos, escritores e historiadores de la época, que finalmente lograron que sus ideas fueran plasmadas en los manuales escolares, dictados en los colegios y filtradas en la cultura popular, de manera que fueran aprendidas por antioqueños de todas las clases.

\subsection{Los blancos de Antioquia}

Tomás Carrasquilla (1858-1940), uno de los principales exponentes de la literatura antioqueña de la época, se presenta a sí mismo como hijo de "más blancos que el Rey de las Españas".

$Y$ es que no fue hasta finales del siglo $X X$ que en Colombia se reconoció, por lo menos de manera oficial con la Constitución de 1991, que se trataba de una "nación multiétnica y pluricultural". Sin embargo, lo que parecería un gran avance para un país poblado por indígenas de diferentes grupos, colonizado por europeos -en su mayoría españoles-, en el que la principal mano de obra esclava durante la Colonia fueron negros de diferentes regiones africanas, y donde las mezclas entre unos y otros fue tan temprana como la llegada de los conquistadores, dicha contemplación para Peter Wade (1997) no es más que una nueva versión de "una realidad pre-existente", en vez de una "ruptura total con el pasado" (p. 290).

ESTE servidor de vosntros nació, ha mas de once lustros sin que huhiera anunciado el grande aconte. cimiento ningún signo mirlerioso ni en el cielo ni en la tierra. Fue ello en Sa!ltodomingo, un poblachón encarantado en utios riscos te Antioquia. Segun unos, se parece a un nido de águila; segun olros. a un tabu. rete. Opto por el asiento. Fn todo caso, en un pueblo de tres efes, como dicen allá mismo: feo, frio y faldudo.

Mis padres eran entre pobres y acaidalados, en.

tre labriegos y señorones y más blanons que el Rey de lus Españas, al decir de mis cuatro abuelos. Todos ellos eran gentes patriarcales, muy temerosas de Dios y muy buenos vecinos.

Fuente: Carrasquilla (1992). 
El antropólogo británico se refiere así al concepto de mestizaje en América Latina y la manera en que se ha usado, pues para él lejos de representar la mezcla existente en el continente, es más una forma nacionalista del blanqueamiento y una de las principales manifestaciones de racismo en la sociedad, pues las élites "insisten en la imagen de una nación heterogénea con distinciones de clase, raza y región precisamente porque, como élites requieren y se benefician de las jerarquías establecidas por tales distinciones" (Wade, 1997, p. 280).

El mestizaje es un planteamiento también trabajado por varios de los intelectuales promotores de la idea de "raza antioqueña" a favor de sus postulados de superioridad, así que se refieren a los paisas como el producto de una mezcla de todos los mundos encontrados en su territorio, tal como sucedió en el resto de América, pero reconociendo que en Antioquia coincidió lo "mejor" de los elementos negros e indígenas, como puede observarse en la siguiente cita de Ricardo Uribe (1942) hecha por Escobar (2004, p. 129):

"Sus peculiaridades (del antioqueño) han sido fruto del medio ambiente y la herencia racial en el que predominaron el elemento español vascongado y el indígena caribe, este último más vigoroso y luchador que el chibcha, por ejemplo, sin olvidar el aporte africano que nos aumentó la capacidad de resistencia contra el clima homicida" (1942, p. 11).

Manuel Uribe Ángel también recurre al mestizaje a la hora de relatar el poblamiento del departamento, pero lo hace para confirmar uno de los postulados de Wade sobre "blanqueamiento" y "homogeneización" logrado por este concepto, ya que en vez de reconocer el papel de cada componente, lo blanco absorbe a los demás para convertirse en uno solo que se asimila más al tipo "superior europeo":

"En el Compendio de Uribe Ángel se explicó el proceso de poblamiento de la región de Antioquia por medio de la mezcla de blancos, negros e indígenas, dando como resultado una 'nueva raza' que al 'calificarla de buena y bella [...] debe entenderse que en ningún caso la consideramos superior a la raza caucásica, la más inteligente de todas las que existen' (Escobar, 2009, p. 227).

Beatriz Nates Cruz también analiza el papel de lo indígena en la cultura paisa y dice que se encuentra en el plano de lo folclórico y al igual que en la representación de Ricardo Uribe, se trata de un grupo especial y de alguna manera superior a otros nativos:

"Confinada la figura de lo indio al plano del folclor, a menudo se presentan mitos y leyendas donde aparece la figura del indio con plumas y tocados, desnudo y pintado el cuerpo como los indígenas amazónicos, apropiándoselo como el 'Cacique Pipinta'. Es decir, si existieron indígenas en la región que los antecedieron, éstos debieron ser seguramente "de élite" y, además, con toda la 
parafernalia de la idealización de un indio, tal como se enseña en las escuelas" (Nates, 2009, p. 289)

Con límites raciales tan claros en este imaginario, vale la pena analizar la importancia de lo "blanco" en la conformación de la "raza antioqueña", que como podemos ver también se hace a manera de exclusión de lo indígena y lo negro: en ese sentido Peter Wade (1987) concluye que uno de los supuestos del paisa es que es opuesto al negro y tiene un "rechazo social y cultural" hacía él, pero que al mismo tiempo es parcial, en especial cuando se acerca a lo blanco y se adapta a ello; mientras que Nancy Appelbaum (2007) demuestra la manera en que el mito de la "raza antioqueña" en gran medida fue una maniobra social y política para ampliar las fronteras del departamento "blanco" -como era considerado Antioquia-, pero también para excluir de ciertas regiones a los indígenas, dentro del famoso proceso conocido como la Colonización antioqueña.

\subsection{Los "aventureros" de Antioquia, la bella de piel clara}

El pintor Francisco Antonio Cano es uno de esos intelectuales antioqueños que se dedicó a promover la unicidad de la raza antioqueña y sus valores, y su obra culmen, Horizontes, se convirtió en el símbolo de la cultura paisa y de ese proceso histórico tan estudiado en Colombia y denominado Colonización antioqueña, con el que se explica la manera en que los habitantes de la entonces provincia de Antioquia migraron hacía el sur y conformaron nuevos departamentos.

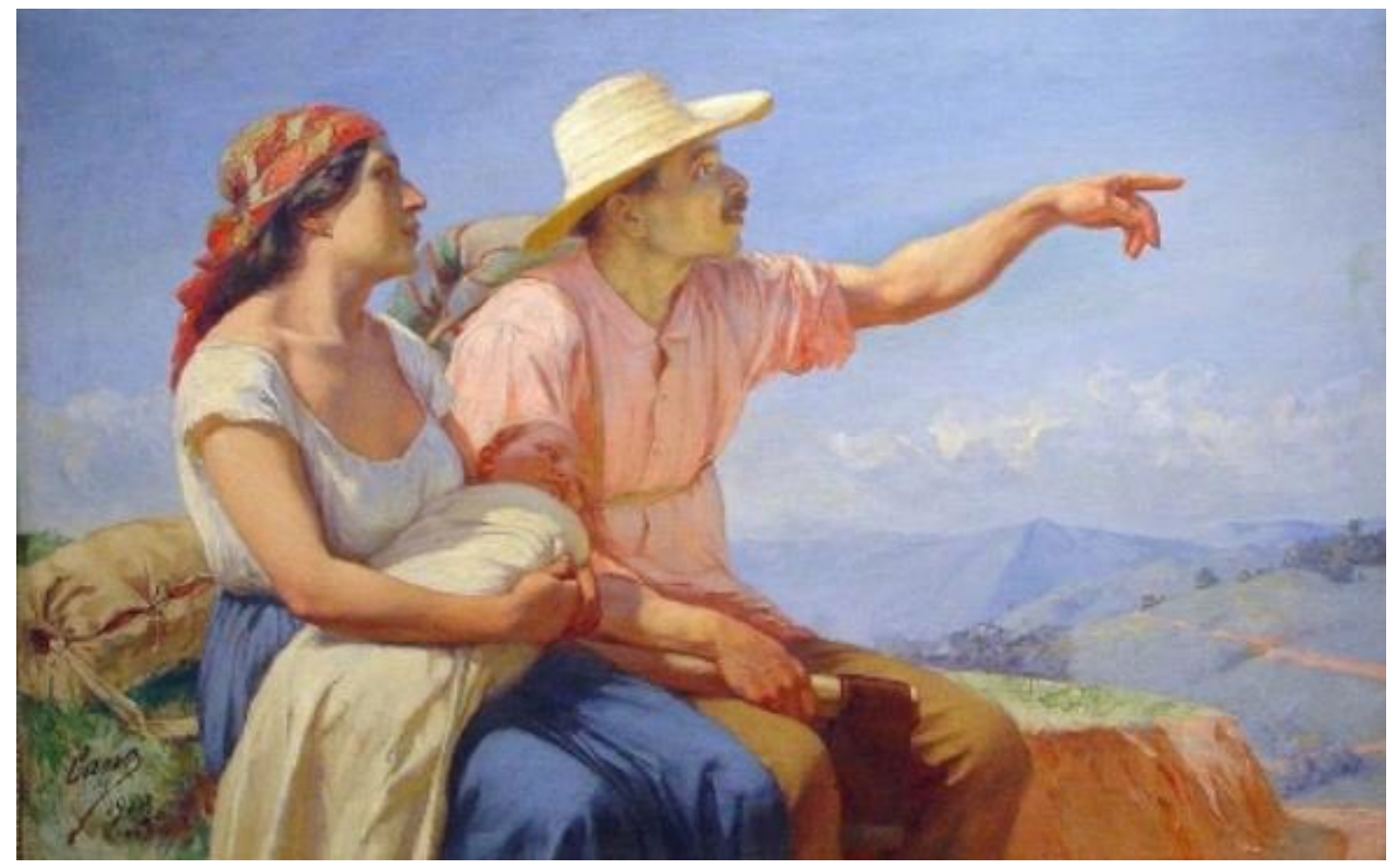

Fuente: Cano, Francisco Antonio (1913). Horizontes. Museo de Antioquia. 
En la obra se pueden ver a una familia de tez clara, con la típica vestimenta campesina antioqueña -muy similar a la que usan hoy los silleteros cada año en su desfile- con su mirada hacia adelante, que se interpreta como puesta en el futuro y el progreso: él con un hacha en la mano ${ }^{20}$, elemento que puede entenderse como símbolo del trabajo y su amor a él como característica principal del paisa, mientras que la mujer, en su papel tradicional de madre y esposa, se encarga de sostener al bebé y dejarse guiar por la mano de su marido que señala hacia el porvenir.

"Ahora bien, detrás de ese apogeo artístico se desarrolló también un discurso identitario que se coronó de gloria cuando el pintor Francisco A. Cano, después de haber regresado de París, fundar y dirigir el Instituto de Bellas Artes de Medellín, dio a conocer su cuadro Horizontes en 1913. Éste se convirtió rápidamente en lo que podríamos denominar la metáfora del 'héroe antioqueño"' (Escobar, 2004, 136).

Y ese "héroe" es el aventurero colonizador antioqueño, el que se llevó a su familia a nuevas tierras, que desde Antioquia se ve como un hacedor de civilización al llegar donde antes "no había nada" -como dice el vídeo oficial de la Feria de las Flores de 2011-, y es observado desde las regiones a las que llegó como un portador de progreso y avance para esos territorios. Y aunque esta no es la única visión de la Colonización antioqueña, sí es la más aceptada y la que favoreció y consolidó la visión de "raza".

Es mucho lo que se ha estudiado este tema dentro de la historiografía colombiana, lo que tal vez puede explicarse debido justo a ese interés por promoverlo, pero para este trabajo se tomarán dos autoras con puntos de vista interesantes para lograr los objetivos de este trabajo y que cuestionan la visión tradicional sobre el proceso mencionado anteriormente: Beatriz Nates Cruz, que se refiere a la Colonización antioqueña como manera de explicar el "mundo" de los paisas y Nancy Appelbaum, quien estudió las diferencias raciales en Riosucio, Caldas, una de las poblaciones a las que llegaron los colonizadores.

"Durante el siglo XIX y principios del XX, olas sucesivas de mineros, agricultores y ganaderos migrantes despejaron y se asentaron en las boscosas faldas de los Andes y en sus valles, entre los dispersos pueblos coloniales de las tierras altas. La más celebre y estudiada de estas corrientes migratorias ha sido la colonización antioqueña. Esta comenzó hacia finales de la Colonia y continuó a través del siglo $\mathrm{XX}$; la creciente población de lo que hoy es la parte central y oriental de Antioquia

20 "El hacha que mis mayores me dejaron por herencia, la quiero porque a sus golpes libres acentos resuenan" dice el himno antioqueño en 1868, un poema creado por Epifanio Mejía, otro promotor de la "raza antioqueña". 
se esparció hacía las áreas vecinas, particularmente al departamento del Cauca. Los migrantes antioqueños expandieron la producción agrícola y desarrollaron redes comerciales por todo el noroeste colombiano" (Appelbaum, 2007, p. 29).

Este movimiento poblacional se explica en gran medida gracias a diferentes disposiciones legales que favorecieron la ocupación de ciertos territorios con el ánimo de "blanquear" determinadas regiones, siguiendo un poco las corrientes migratorias promovidas en otros países de América Latina como Cuba, Argentina o Brasil, quienes pudieron subsidiar y atraer europeos a sus territorios. En el caso colombiano, en vista de las dificultades para promover la inmigración desde el viejo continente se aprovechó la jerarquía regional basada en razas, para promover la expansión de los habitantes de las zonas "blancas" hacia las demás.

“Los colonizadores por excelencia de todo este grupo son los 'paisas' de Antioquia quienes detentan lo que se ha llamado en Colombia la Colonización antioqueña, animada por varias disposiciones jurídicas, comenzando por la ley de ocupación de tierras del 13 de octubre de 1821, por la ley 31 de 1823 sobre 'apertura de caminos', por el decreto del 27 de mayo de 1842 en el que se estipula el derecho a casa y labranza (incipiente configuración de la finca) y, finalmente, por la ley 61 de 1874 de los Estados Unidos de Colombia, con la estipulación del derecho a habitar tierras sin medida de extensión siempre y cuando fuesen habitadas y cultivadas" (Nates, 2009, p. 287).

De todo este proceso surge uno de los rasgos más característicos atribuidos a los antioqueños: el de hombres aventureros y hábiles para los negocios como bien lo dice Nates (2009) "una imagen recurrente era la del paisa andariego", el cual se mostraba "recorriendo la región con su atuendo tradicional (alpargatas o pies descalzos, sombrero aguadeño, carriel y poncho doblado al hombro)", de nuevo el mismo vestuario tradicional de los silleteros de Santa Elena: "este arquetipo masculino (que más tarde se haría famoso con las campañas publicitarias de la Federación Nacional de Cafeteros) era generalmente caracterizado como el protagonista principal de la épica de la colonización antioqueña" (p. 220).

Pero volviendo a la historia de la colonización antioqueña, Appelbaum (2007) asegura que existe una "leyenda blanca", a la cual ya nos hemos referido, en la que "familias antioqueñas honradas y blancas" ocupan territorios despoblados y vírgenes dándole uso y facilitando el progreso de dichas regiones. Pero también existe una visión menos positiva, una "leyenda negra", en la que se habla de un despojo de tierras a los indígenas, pues como era de esperarse, no se trataba de territorios vírgenes que aguardaban por el "impulso civilizador del hacha antioqueña", a lo que se suma que "recientes estudios muestran un proceso de colonialismo más que mera colonización agrícola: los antioqueños se tomaron las 
comunidades, los gobiernos locales, las redes comerciales y la tierra -a lo que el riosuceño Julián Bueno se refirió como una “invasión-"' (p. 31).

Pero hay un tercer elemento, que no tienen en cuenta ninguna de estas perspectivas y es el "blanqueamiento" en el que trabajaba el continente en ese momento, y que en Colombia se hizo usando la jerarquía regional, así que cuando se despoja a la Colonización antioqueña del arquetipo de paisa aventurero, puede verse más claramente un proyecto nacional de construir un país más acorde a los estándares raciales impuestos por Occidente, con lo que Antioquia como provincia "blanca" debía imponerse sobre territorios "indígenas" como Cauca, una empresa que solo fue posible por el interés de las élites de estas últimas zonas, ya que percibían en los antioqueños atributos como "blancura, familias ordenadas, modernidad, prosperidad, políticas conservadoras y devoto catolicismo" (Appelbaum, 2007, p. 220).

"Al facilitar el asentamiento de los antioqueños, la élite caucana tenía la esperanza de blanquear el Cauca y así acercarse a la imagen que tenia de Europa y Estados Unidos, o al menos, a la imagen que tenía de Antioquia. Buscaban llevar progreso a, transformando su población -en otras palabras, colonizándolo racionalmente-. Para las élites latinoamericanas 'progreso' significaba prosperidad comercial y modernización capitalista” (Appelbaum, 2007, p. 220).

Así que al tiempo que la Colonización antioqueña recurrió a la noción de "raza" y sus implicaciones para justificarse, también se convirtió en un mito con el que de alguna manera se siguió confirmando la idea del paisa con cualidades especiales, que al mismo tiempo le permitió seguir ocupando territorios y consiguiendo poder en el país, como puede extraerse del trabajo de Peter Wade con comunidades afrocolombianas, donde afirma que según dicha ideología de "raza antioqueña" los términos "paisa” y "negro" son opuestos (1987, p. 40).

Tal como sucedió en el Cauca y otros departamentos del sur y occidente de Colombia durante la colonización antioqueña, en Chocó, una de las regiones negras de Colombia, los paisas también se beneficiaron de su "superioridad" racial para explotar el territorio económicamente, "los antioqueños, con su tradición de colonizadores dinámicos y comerciantes intrépidos, y con su mayor acceso al capital, han penetrado el subdesarrollo del Chocó para manejar el comercio, la ganadería y, en menos grado, la minería” (Wade, 1987, p. 35).

Consecuencia de este tipo de procesos es que en América Latina y Colombia exista una "correlación aproximada entre la definición racial y la condición económica de las regiones" (Wade, 1997, p. 30), de manera que aún hoy los antioqueños se benefician de esa distinción racial histórica, que según Wade no es cierta: 
"De hecho la supuesta ausencia de presencia y herencia negras es completamente falsa, pero el mito inadvertidamente sí revela una historia de procesos poderosos de mezcla de razas que en alguna medida blanquearon lo negro que había sido prominente en la población colonial. Antioquia es por lo tanto un excelente ejemplo de una región donde los procesos económicos, demográficos y políticos estructuraron el mestizaje de una manera tal que estimularon la dispersión de lo negro" (Wade, 1997, p. 101).

Pero si no había una prominencia de lo blanco en Antioquia, ¿por qué se logró crear un imaginario de identidad blanco y no sucedió lo mismo en otras regiones? Porque las élites antioqueñas también tuvieron en cuenta a las clases populares y sembraron en ellas la semilla de la "raza antioqueña" en procesos como la Colonización, protagonizada por familias campesinas, gracias a quienes se consolidó un supuesto de superioridad racial que todavía no ha desaparecido.

"Una gran parte de la identidad paisa se desarrolló en un medio plebeyo: en la intimidad de las familias rurales de los colonizadores; a través del catolicismo del hogar, donde los niños eran abofeteados si dormitaban mientras rezaban su rosario de rodillas frente al fuego; alrededor de esas mujeres antioqueñas que daban a luz 20 o 30 hijos; alrededor de los arrieros que inducían a sus bestias con halagos hacia cada rincón y cada grieta de los escarpados terrenos, que alimentaban los mercados locales y la capital de la región y que se desplazaban hacia el sur con los mismos colonizadores; alrededor del maíz con el cual hacían sus arepas y su mazamorra" (Wade, 1997, p.108).

\subsection{Imágenes paisas antes y después del narcotráfico}

Se conoce como paisa a los habitantes del centro de Colombia, entre los departamentos de Antioquia, Caldas, Risaralda, Quindío y norte del Valle del Cauca, quienes comparten unas costumbres similares y se consideran parte de una misma cultura. Tal identidad surgió como imaginario de identidad durante el proceso de regionalización del país, marcado por el tema racial, en medio de las búsquedas identitarias de la nueva república de Colombia.

En el listado anterior vale la pena aclarar que los primeros son considerados como los paisas "originales", pues fueron quienes llevaron la cultura de la "raza antioqueña" mediante la migración de sus habitantes a los demás, que son departamentos surgidos o "mejorados" durante la Colonización antioqueña. Por eso, según Nates Cruz (2009) "son vistos por el resto de los colombianos como 'colonizadores' y como 'verracos', término cuyo uso social alude a 'aguerrido', 'valiente'. Pero ellos mismos también se autodenominan con la segunda categoría" (p. 287). 
Son muchos los atributos que se le asignan al antioqueño o paisa y como bien lo dice María Teresa Arcila (1994), empezar a enumerarlos y buscar sus orígenes puede resultar una tarea "dispendiosa y poco productiva" (p. 98), sin embargo como ella misma lo hace, sí que vale la pena mencionar los más destacados dentro del reconocimiento cultural del antioqueño: "dedicación y amor al trabajo, habilidad para los negocios, interés y ocupación en el comercio, honradez, honestidad y defensa del orden y de las instituciones" (p. 98).

Imágenes como el mazamorrero (minero independiente), el arriero (transportador de mercancías a lomo de mula) y el campesino cafetero marcaron la historia de Antioquia por su influencia en la economía de la región y se convirtieron de alguna manera en la síntesis "del modo de vida de ser antioqueño, su esencia y valores culturales" (Arcila, 1994, p. 112). A ellos se les suma y les antecede uno que hoy en día ha vuelto a ser representativo gracias a su papel en la Medellín de mediados del siglo XXI, el silletero, pero que tiene sus antecedentes en los cargueros de personas y mercancías de los que dan cuenta los viajeros de los siglos XVIII y XIX, que sin ayuda de caballos llevaban sus clientes o encargos a espaldas.

Así que no sorprende la relación de la cultura paisa con el silletero y la elección del desfile como una de las representaciones de la misma, no solo por considerarse como los herederos de los cargueros, sino también por usar el vestuario de los cafeteros y tener su misma procedencia campesina; contar con la resistencia de los mazamorreros, que como ellos necesitaban largas y extenuantes jornadas para realizar su trabajo; y el amor al trabajo del arriero que recorría largos caminos, tal como lo hace el silletero con sus pesadas flores, llevando la cultura antioqueña más allá de los límites regionales.

Además, el primer desfile de silleteros, con el que se instaura oficialmente la tradición por decirlo así y empieza de alguna manera la relevancia identitaria y cultural que hoy tienen estos personajes, coincide con un momento en el que Antioquia empezó a sentir el freno de su prosperidad con la crisis económica y la violencia de la segunda mitad del siglo XXI, y por lo tanto, existe una necesidad evidente de recuperar las cualidades de la "raza antioqueña" que se ven amenazadas ante una "pérdida de valores", que en parte ha servido para explicar la difícil situación de la época.

“¿Cómo pasó Medellín de ser un modelo de paz civil y orden social a un sinónimo internacional de criminalidad y violencia? Aunque los antioqueños generalmente lo atribuyen a la pérdida de los valores familiares patriarcales de 'los abuelos', muchas de las investigaciones recientes, citadas en este capítulo, sugieren que muy posiblemente fueron esos venerados abuelos quienes esparcieron la semilla de la violencia actual en Antioquia. La violencia era integral no solo para el 
'desordenado' Cauca, sino también para la 'ordenada' Antioquia. Al igual que en el estereotipo de su hogar antioqueño, esos abuelos, otrora dirigentes de Antioquia, tuvieron mucho éxito imaginándose su sociedad regional como una familia en la cual el legítimo patriarca usaba una mezcla de coerción y afecto para controlar y disciplinar a los subordinados miembros de la familia" (Appelbaum, 2007, p. 89).

Arcila por su parte se refiere al famoso "amor al trabajo" y la honradez como elementos sobre los cuales se formó la imagen positiva del paisa, y llega a la conclusión de que más que por su trabajo, el antioqueño se valora como "hacedor de plata" y en esa medida, el arriero, el campesino cafetero y el mazamorrero tienen algo en común y es que laboran para terceros, que son los finales acumuladores de riqueza, de manera que se trata de una sociedad que históricamente ha promovido la desigualdad y lo que esta conlleva:

"Transcurridas más de dos décadas luego del surgimiento del narcotráfico en Colombia queda claro que el trabajo creador de, que se realiza de manera honesta y honrada, no es un valor sobre el cual se sostenga necesariamente la identidad antioqueña. Aquel fue solo un instrumento contingente y accesorio que permitió en determinadas circunstancias acceder a la riqueza, verdadero valor y objetivo cultural.

En la actualidad la crisis económica y social en Antioquia ha dejado al descubierto una realidad: en esta cultura los hombres no son reconocidos y valorados como trabajadores creativos, decididos y recios, sino por la riqueza que sean capaces de producir o poseer, no importa los métodos que utilicen para conseguirla" (Arcila, 1994, p. 117).

Así que el difícil periodo del narcotráfico en la ciudad fue más allá de las pérdidas evidentes de cualquier conflicto y puso en tela de juicio todas aquellas características que por décadas habían sostenido la imagen local y la identidad de la que se sentían orgullosos sus habitantes. Por eso, tampoco es de extrañar que tan pronto la región empezó a superar esas épocas, los gobiernos intentaron superar dicha crisis mediante el regreso a esos "valores ideales" que hicieron a Antioquia una región "pujante":

"Es así como lo sectores sociales dominantes han realizado esfuerzos desesperados por revivir un discurso que permita recomponer los valores que conformaban tradicionalmente la identidad antioqueña; aunque el discurso decimonónico de la valerosa gesta colonizadora y los valores campesinos de los momentos de gloria sobre los cuales se construyó el orgullo regional, hayan perdido su contenido y vigencia, y se ha tratado de restablecer aquellos valores desde una perspectiva etnocéntrica del mundo. Lo que antes era un reconocimiento al carácter diferente del antioqueño, se convirtió en regionalismo a ultranza, sentimiento de superioridad de la cultura antioqueña, desprecio por las demás" (Arcila, 1994, p. 117). 
Ahí es donde volvemos a encontrar a los silleteros como unos aliados fundamentales para reforzar el pasado y las cualidades positivas de la Antioquia industrializada y emprendedora, de manera que al verlos como humildes campesinos, aguerridos y trabajadores, se dice que cuando ellos pasan es Antioquia la que pasa, como pregona su lema más popular cada año mientras desfilan por las calles de Medellín, pues como dice el silletero Héctor de Jesús Ruiz Hernández:

"Para mí ser silletero es como el significado sería primero ser uno campesino, lo otro ser antioqueño, sentirse o ser uno buen paisa, cierto, entonces eso es como una cosa agradable y un orgullo ser silletero y algo que se lleva en la sangre porque de verdad se lleva en la sangre, es muy bueno para todos" (Entrevista personal a Ruíz, abril 7 de 2012).

Así que ellos mismos ya se consideran un símbolo de la cultura antioqueña-paisa, como asegura el también silletero Carlos Alberto Atehortúa, presidente de la Corporación Silleteros de Santa Elena:

"Ser silletero para nosotros es un orgullo, el hecho de ponernos un traje de estos es un orgullo, salir a representar a una ciudad como Medellín o un departamento como Antioquia o un país como Colombia es mucho orgullo. Ser silletero para mi es llevar por dentro de nuestra sangre esa cultura, esa verraquera, esa tenacidad, ese amor, esa responsabilidad de nuestros abuelos y tatarabuelos de hace mucho tiempo, es una responsabilidad muy grande que llevamos con mucho orgullo. Cuando salimos a representar a nuestro país, o en otra ciudad lo hacemos con mucho gusto y orgullo" (Entrevista personal a Atehortúa, octubre 6 de 2012).

Pero es una idea que no solo puede intuirse y confirmarse con la declaratoria patrimonial o las opiniones de los mismos silleteros, los medios de comunicación también replican de manera amplia ese discurso, de manera que dentro del total de artículos analizados dedican entre el 7\% (EI Tiempo) y el $8 \%$ (El Colombiano) a relacionar a los silleteros con los valores paisas tradicionales, lo que equivale a un total de 11 textos en ambos medios, dentro de los que se pueden ver titulares como "Pujanza, verraquera y orgullo antioqueño en el Desfile de Silleteros" (El Colombiano, agosto 10 de 2014) o textos como el enviado por Asdrúbal Salazar a la sección "Cartas a la directora" de El Colombiano (Opinión, 2014), en el que se puede leer: "bajo el peso floral de la silleta hay un hombre sencillo y honrado" para continuar con "por eso se siente el empuje de la raza cuando por las calles, en silencio pasa con su carga floral un silletero".

Incluso citan a espectadores del desfile en este mismo sentido, es decir, antioqueños que según las declaraciones que hacen a los diarios consideran a los protagonistas de la jornada como símbolos de su cultura, "la paisa". Es el 
caso de Gabriel Velásquez, asistente al desfile de 2011, para quien "es toda una cultura la que sale a caminar hoy" (Rivera, 2011) o el de María Gisela Restrepo, también espectadora del evento en 2007, "las costumbres, las de nosotros los paisas, o al menos de los que habitamos Medellín, son estas, las de los silleteros" (Redacción, 2007).

Así que no es necesario devolverse hasta el siglo XIX para encontrar publicaciones que hablan sobre la "raza antioqueña" y los valores paisas, si bien sucede especialmente durante la Feria de las Flores, en cualquier momento del año solo hay que abrir un diario nacional como El Tiempo y encontrar el titular "Una raza que desborda de alegría", como parte de un especial de los 200 años de la independencia del departamento, dentro del cual se leen descripciones de los habitantes de la región homenajeada como los siguientes:

"La antioqueña parece ser la cultura del más. Eso se nota al escuchar a los guías turísticos y al oír los relatos de los lugareños desprevenidos, que por lo general, son buenos conversadores, amables y dicharacheros" [...]

"Los paisas se precian de ser lo más amables, emprendedores, innovadores y trabajadores. Por eso dicen hacer las mejores ferias y fiestas del país" (Especial Antioquia 200 años, 2013).

Y tampoco es extraño, encontrar que el 6 de agosto de 2006, el entonces reelegido presidente de Colombia, Álvaro Uribe (durante su mandato se patrimonializó a los silleteros y su desfile), antioqueño, con un marcado acento paisa y quien en muchas oportunidades usa elementos del vestuario típico de la región, aprovechó el desfile, un día antes de su nueva posesión como presidente, para apelar a sus raíces y exaltarlas. Él mismo tras la declaración del evento como patrimonio cultural de la nación se refirió a estos personajes relacionándolos directamente con el "ser antioqueño":

"Los silleteros han sido el ejemplo de la expresión típica del trabajo antioqueño: disciplina, constancia, creatividad, solidaridad, solidaridad en el mundo, solidaridad con Colombia. Han sido solidarios en todos los momentos, en los cuales Antioquia los ha reclamado, representan esa ética de servir a la gente". (Casa de Nariño, 2004). 


\section{El día}

Para entender una tradición "viva" como es la de los silleteros de Santa Elena es necesario observarla, tanto en su evento principal como en sus preparativos, por eso, este capítulo se dedica a hacer un breve recorrido por la víspera del desfile de silleteros de 2013 y su desarrollo, con el fin de describir de manera general la visita al corregimiento y dar una idea sobre el ambiente y la dinámica que se genera alrededor de la parada, antes y durante la fecha programada cada año.

Para visitar Santa Elena el viernes 9 de agosto de 2013, dos días antes del desfile, había que ir hasta el estacionamiento de los autobuses de transporte público en la calle Ayacucho, justo al lado de la tienda "El Silletero", y a tan solo un par de calles de la Placita de Flórez, el mercado tradicional campesino que con más de 120 años todavía aloja a muchos silleteros como Joaquín Emilio Zapata que comercializa allí sus cultivos orgánicos. Por mucho tiempo este lugar fue una las primeras paradas en el largo camino que recorrían los antiguos silleteros desde sus casas en la Medellín rural, hasta los puntos de distribución de flores y productos agrícolas, ubicados en plazas públicas, iglesias y cementerios, como bien lo recuerda Carmen Emilia Atehortúa Zapata, al hablar de su esposo, "él tenía jardincito y yo también. Él trabajaba en la Placita de Flórez" (entrevista personal a Atehortúa, mayo 12 de 2012).

Incluso hay quienes le dan un protagonismo importante a este sitio dentro del primer desfile de silleteros fechado en 1957: "(los silleteros) primero estaban en la Placita de Flórez, luego a la avenida Oriental con La Playa” recuerda Pastora Inés Zapata (entrevista personal a Zapata, mayo 12 de 2012), quien dice haber estado allí. También el antropólogo Edgar Bolívar menciona este espacio como el sitio de trabajo de los convocados para ese primer evento.

En el camino entre el antiguo mercado y el estacionamiento de los vehículos que van al corregimiento, se pueden ver floristerías como "Dígalo con flores", "Mundo flor" y "Floresymas.co". La parada se reconoce por los colectivos medianos de color azul y verde que se encargan de prestar el servicio y que ese día tenían largas filas de pasajeros esperándolos, pues debido a la afluencia de público la vía solo está abierta para autobuses públicos, recorridos autorizados y automóviles locales previamente registrados, con el objetivo de disminuir el tráfico y facilitar la movilidad de los silleteros que al día siguiente se desplazarán al desfile.

Santa Elena está ubicada a 17 kilómetros del centro de Medellín, cuenta con más de 10 mil habitantes y es uno de los cinco corregimientos de la zona rural de la ciudad. Sus personajes más famosos son los silleteros -hay quien afirma que todos sus pobladores lo son como ya se ha visto en capítulos anteriores- $y$ gracias 
a ellos este sector se ha convertido en uno de los más turísticos de la capital antioqueña, en especial durante la época de la Feria, en la que ya se ha vuelto una costumbre la visita a las casas de los protagonistas del desfile, quienes empiezan a construir sus silletas en los corredores y patios de sus fincas, hasta donde llegan turistas ansiosos por ver la manera en que las elaboran, escuchar historias sobre la tradición, probar algún producto típico -y no tanto- o simplemente tomarse una foto con ellos y sus creaciones.

Una vez en el autobús sobresale el sonido de alguna emisora local con música vallenata, ranchera o algún anuncio comercial sobre la festividad hecha por empresas como Bavaria, dueña de la cerveza Pilsen, una de las principales patrocinadoras de la fiesta y que en las últimas ediciones ha lanzado una línea especial llamada "Paisa". Bavaria es también creadora de la canción oficial, a través de la cual se continúan varios de los estereotipos trabajados en esta investigación: "desde Bello hasta Sabaneta la fiesta paisa vamos a formar, con el desfile de autos viejos y la belleza de sus mujeres, quién no se siente orgulloso de haber estado en este pueblo hermoso [...] Medellín eterna primavera, pa' gozar... el amor, la pujanza y verraquera de mi tierra que te espera".
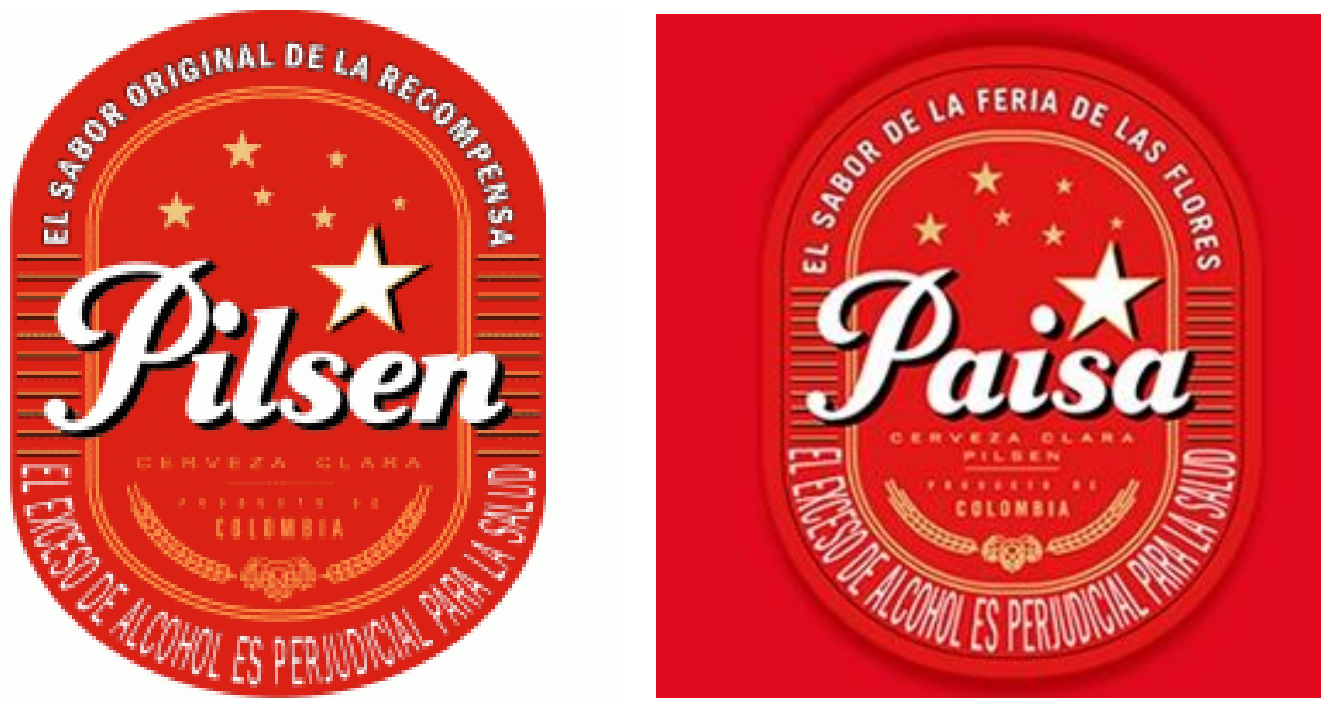

Fuente: recuperado de http://www.brandsoftheworld.com/logo/cerveza-pilsen-0

Fuente: recuperado de http://estiloydiseno.com.co/php/eventosver.php?evento=736\&ciudad=1 


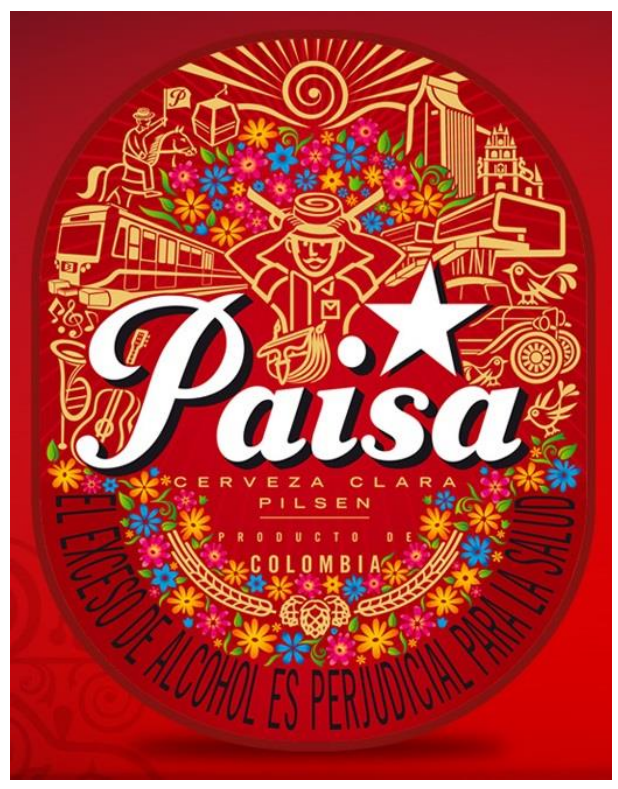

Fuente: http://julianarbelaez.com/propuesta-etiqueta-pilsen/

La ciudad se empieza a abandonar hacia el oriente a través de largas cuestas que se ven por la ventana, mientras en el interior del vehículo, los turistas -la mayoría locales- usan sombreros y ponchos, se ríen, planean su itinerario e incluso se toman un aguardiente. Poco a poco el paisaje gris se torna verde y la ciudad empieza a verse desde lejos como una mancha de cemento, mientras se superan las cerradas curvas del ascenso después de las cuales se encuentran vendedores ambulantes de flores, miel y prendas típicas, que complementan la oferta de restaurantes y tiendas de recuerdos ubicados a lo largo de la carretera.

El trayecto de más o menos 45 minutos termina en el centro de Santa Elena, unos metros más adelante del Comando de Policía y justo donde hay una plaza pública. Allí puede verse el monumento a los personajes más famosos del lugar: un hombre con carriel, poncho y sombrero lleva una silleta a cuestas y está en medio de dos mujeres, una adulta vestida con falda y delantal, y una niña con un sombrero, en frente de los tres se puede leer la emblemática frase "Cuando pasa un silletero es Antioquia la que pasa".

En medio de la plaza hay una especie de teatro al aire libre donde se celebran los eventos públicos, a su alrededor no hay viviendas, pero está la iglesia, hay varios restaurantes, tiendas y espacios para comprar recuerdos. Al lado izquierdo se encuentra la casa de gobierno y varios metros más adelante la secundaria. Una vez allí los turistas suelen preguntarse qué hacer, pues aunque no hay silleteros ni silletas -porque los primeros están en sus casas haciendo las segundas-, el parque está lleno de visitantes con sombreros y ponchos que compran, comen, beben, se toman fotos y bailan. 


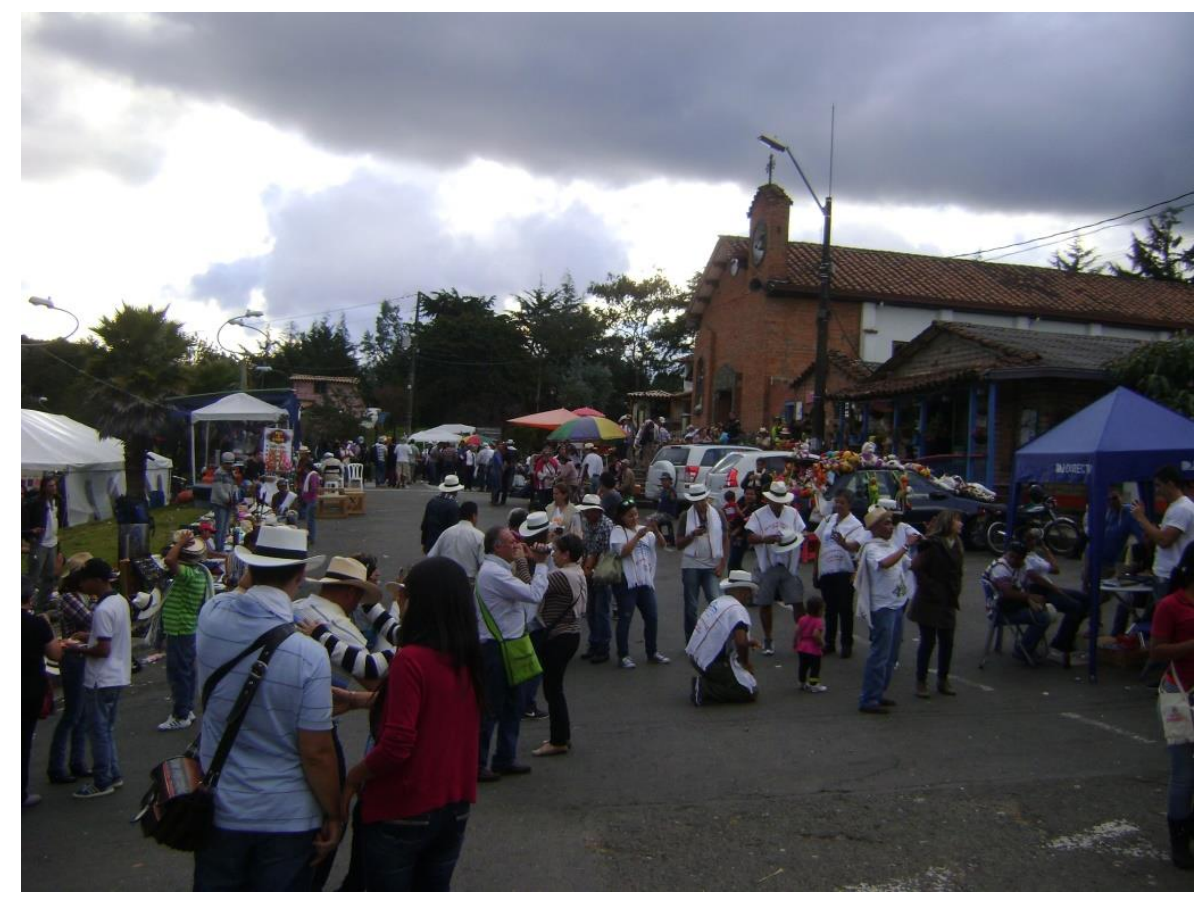

Santa Elena, agosto 9 de 2013.

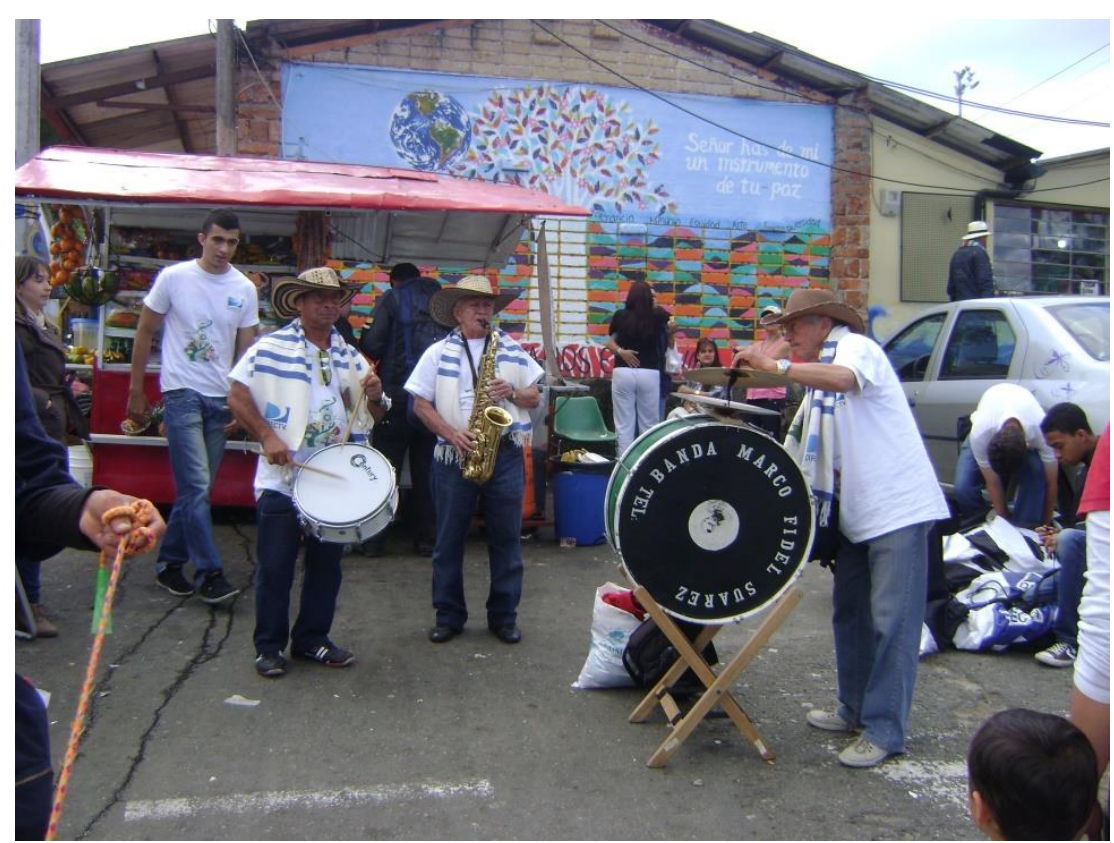

Santa Elena, agosto 9 de 2013. 


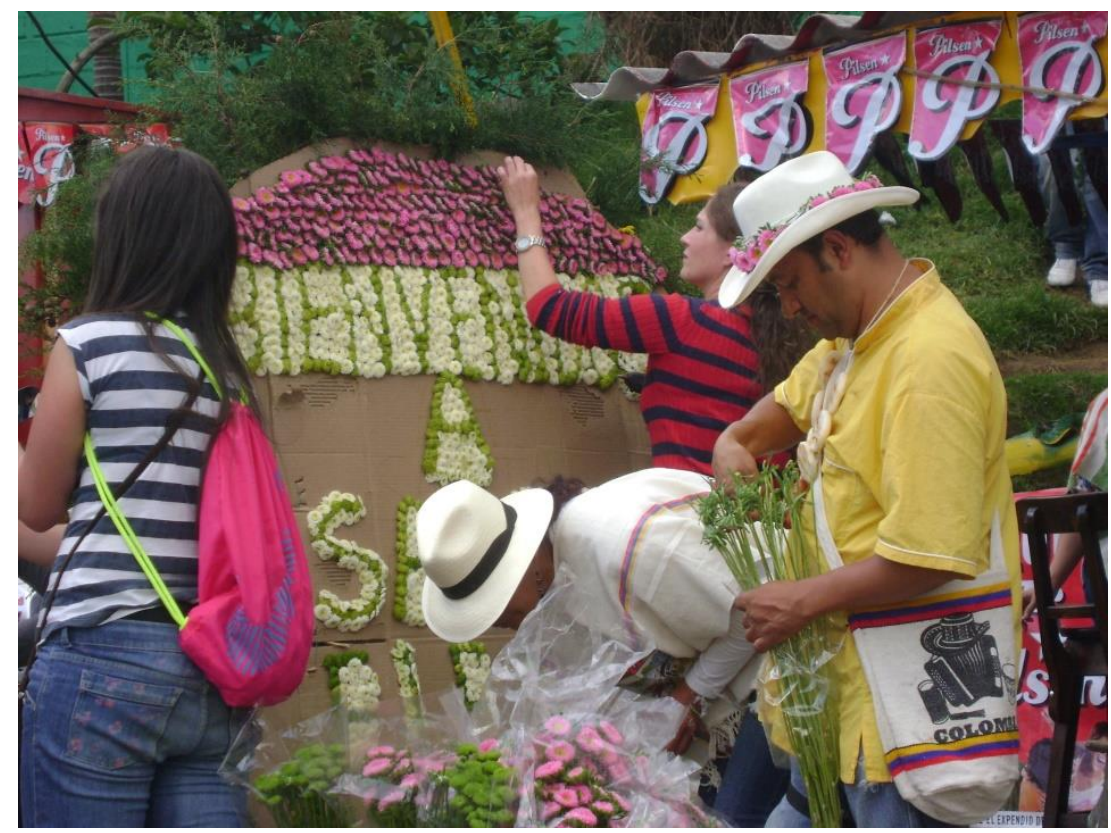

Santa Elena, agosto 9 de 2013.

En las últimas décadas con el crecimiento turístico de la zona es muy fácil encontrar guías que ofrezcan paquetes de transporte, alimentación y visita a las fincas de los silleteros, espacios en los que es posible hablar con ellos, ver como construyen las silletas e incluso llevar una a cuestas. Gracias al proyecto de las fincas silleteras ya mencionado, los recorridos son más preparados, regularizados y completos. Juan Guillermo Londoño, propietario de una de ellas, cuenta que los visitantes pueden ir a su casa en cualquier momento del año y ver la colección de objetos antiguos que tiene, las fotografías de sus antepasados silleteros, las distinciones que ha ganado con su participación en el desfile, además del jardín que cultiva en el exterior y la silleta que prepara, lo cual varía dependiendo del servicio solicitado.

"Las visitas antes eran libres, llegaban, hacían desorden. Por eso decidimos organizarlo para convertirlo en un programa turístico, atractivo e interesante, sobre todo al turismo de afuera porque al de aquí no le llama tanto la atención, no va a pagar por eso y eso ya tiene unas tarifas, unos pagos porque tener estas fincas no es fácil, además uno no trabaja solo, necesita por lo menos dos personas que le ayuden con la silleta, a cuidar la finca, a contar la historia, a atender las personas, son muchas cosas, hay que llevar mucha documentación, planillas de atención, controles" (Entrevista personal a Londoño, julio 7 de 2012)

Agrega que los días de más movimiento obviamente son los previos al desfile, en especial en las veredas (poblados) más centrales como la suya, Piedra Gorda, así como en sus vecinas El Placer y Barro Blanco, hasta donde el visitante llega bien por tratarse de las primeras que encuentra en su búsqueda de silleteros y silletas, 
o bien por tratarse del destino principal de los operadores turísticos. Pero Londoño dice que hay quien ni siquiera se interesa por las silletas y en vista de la dispersión y dificultades que pueden existir para hallarlas, prefiere quedarse en el parque de Santa Elena y hacer su propia fiesta, con lo que se vuelve un poco a la discusión por la "pérdida de la tradición" debido a la afluencia del turismo y a la que se refiere el silletero Londoño:

"Qué pasa con esta parte de las veredas que son más fuertes como Piedra Gorda, El Placer, Barro Blanco, que son las fuertes en eso, es la concentración de la gente bailando y bebiendo, y dando lidia, lo otro es que la gente piensa también que va a encontrar 450 silletas juntas, 450 silletas están dispersas en todas las veredas y es muy difícil llegar a ellas, y quien no conoce no va a llegar a ellas, es que llega gente a la parte central y dicen donde hay gente bebiendo y ahí se quedan, no ven una silleta" Entrevista personal a Londoño, julio 7 de 2012).

Por eso, más allá de los juicios sobre la "contaminación" de la tradición, resulta muy interesante dirigirse a otro rumbo y conocer cómo viven estos días los silleteros que no reciben tantas visitas, pueden construir sus obras mucho más tranquilos y no tienen en mente un plan turístico. Por eso, es interesante ver qué pasa en la vereda San Ignacio, una de las cuales no pertenece a Medellín y como parte del municipio de Guarne, más alejada del centro, es poco visitada. El bus paró justo en el lugar donde un camión repartía flores blancas entre quienes se acercaban, casi todos hombres adultos, que tomaban su parte correspondiente guardada en cajas de cartón, para continuar la elaboración de su silleta: más adelante, una habitante de la zona explicó que se trataba de la donación de Asocolflores (Asociación Colombiana de Exportadores de Flores), que en 2014 entregó 600 mil tallos, tal como lo hace desde hace 15 años, según el periódico El Tiempo (Jiménez Ruíz, 2014). 


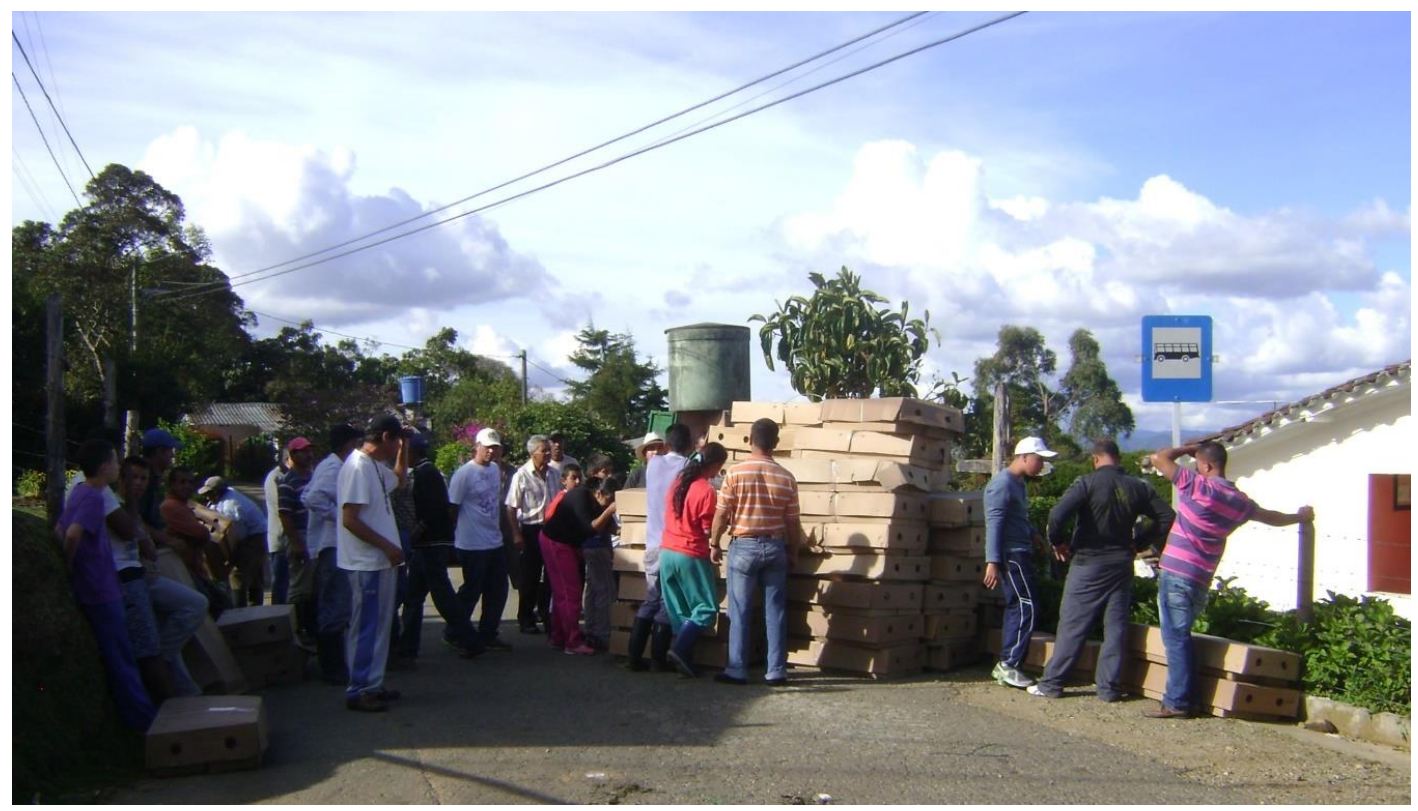

Santa Elena, agosto 9 de 2013.

Para ver la primera silleta había que dejar la vía principal y adentrarse por un camino sin pavimento que daba a la primera casa, ya llena de visitantes, los cuales entran saludando, registrando el momento con sus cámaras y elogiando la belleza de las creaciones. Es la casa de la familia Hincapié, donde se construyen tres silletas, dos emblemáticas y una comercial ${ }^{21}$ : un hombre de mediana estatura con camiseta y pantalón corto pone el follaje sobre el cartón que cubre el armazón de madera, base de todas las silletas y que en su caso se convertirá en un homenaje al bicentenario de la independencia de Antioquia con la frase "200 años de tradición" escrita sobre otra base que ya es exhibida y fotografiada por los turistas.

En la segunda silleta trabajan dos de los hermanos menores, va más avanzada y lleva el logo de un periódico local, pues es patrocinada por el mismo. La tercera será la del debutante, Huber, que irá acompañada por una serie de figuras en relieve cubiertas también de flores, entre las que se cuentan diferentes símbolos de Antioquia como un silletero, una mula, un ferrocarril, un edificio Coltejer, un bus escalera y un metro, con las que piensa adornar la frase "Antioquia paraíso sin fin y tesoro por descubrir". El joven, que participará por primera vez en el desfile dice

21 Existe una clasificación de cuatro tipos de silletas para los participantes en el desfile: tradicional, emblemática, monumental y comercial. Antes de iniciar la parada es elegida la mejor en su categoría. Más adelante se caracteriza y se amplía la información sobre cada una de ellas. 
sentirse algo nervioso, pero al mismo tiempo muy orgulloso de esta oportunidad que tiene de heredar el contrato de su madre y su abuela.

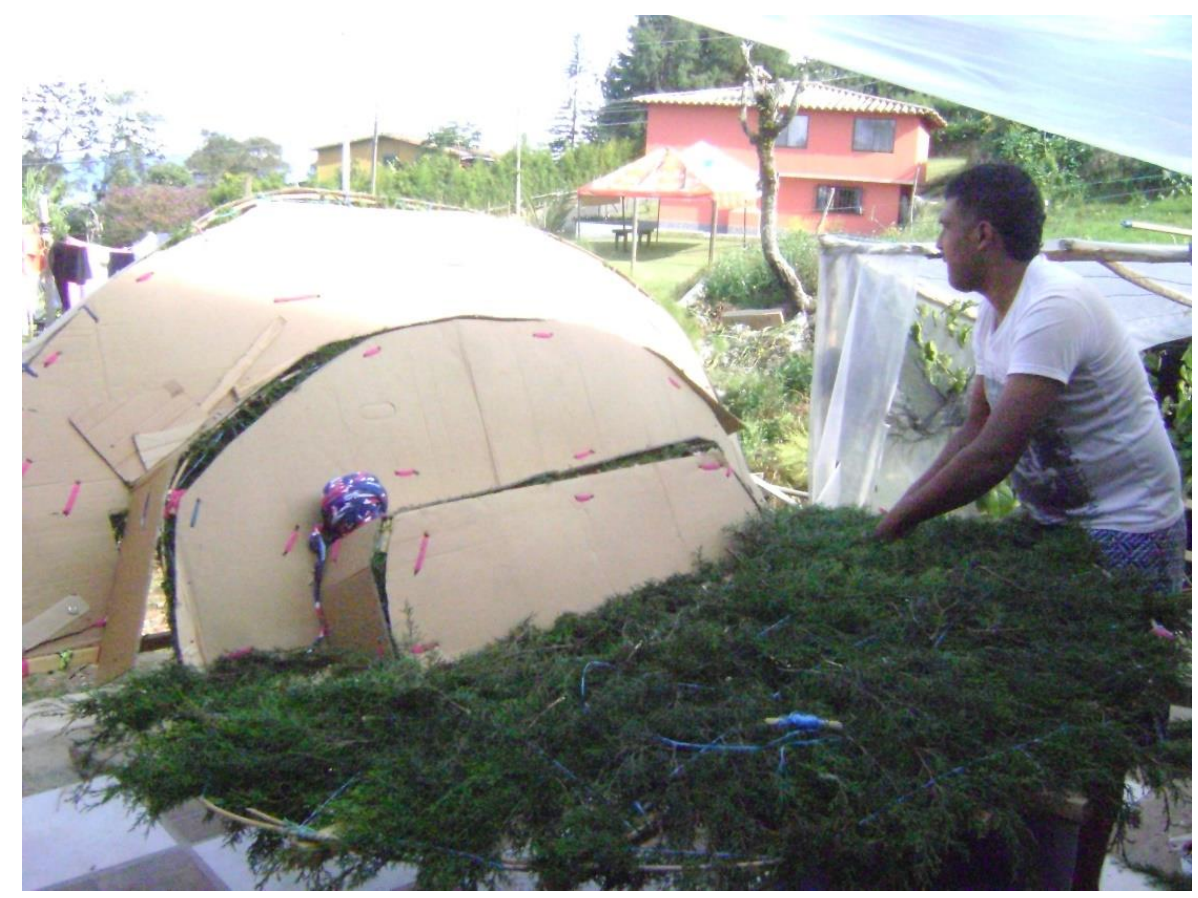

Santa Elena, agosto 9 de 2013.

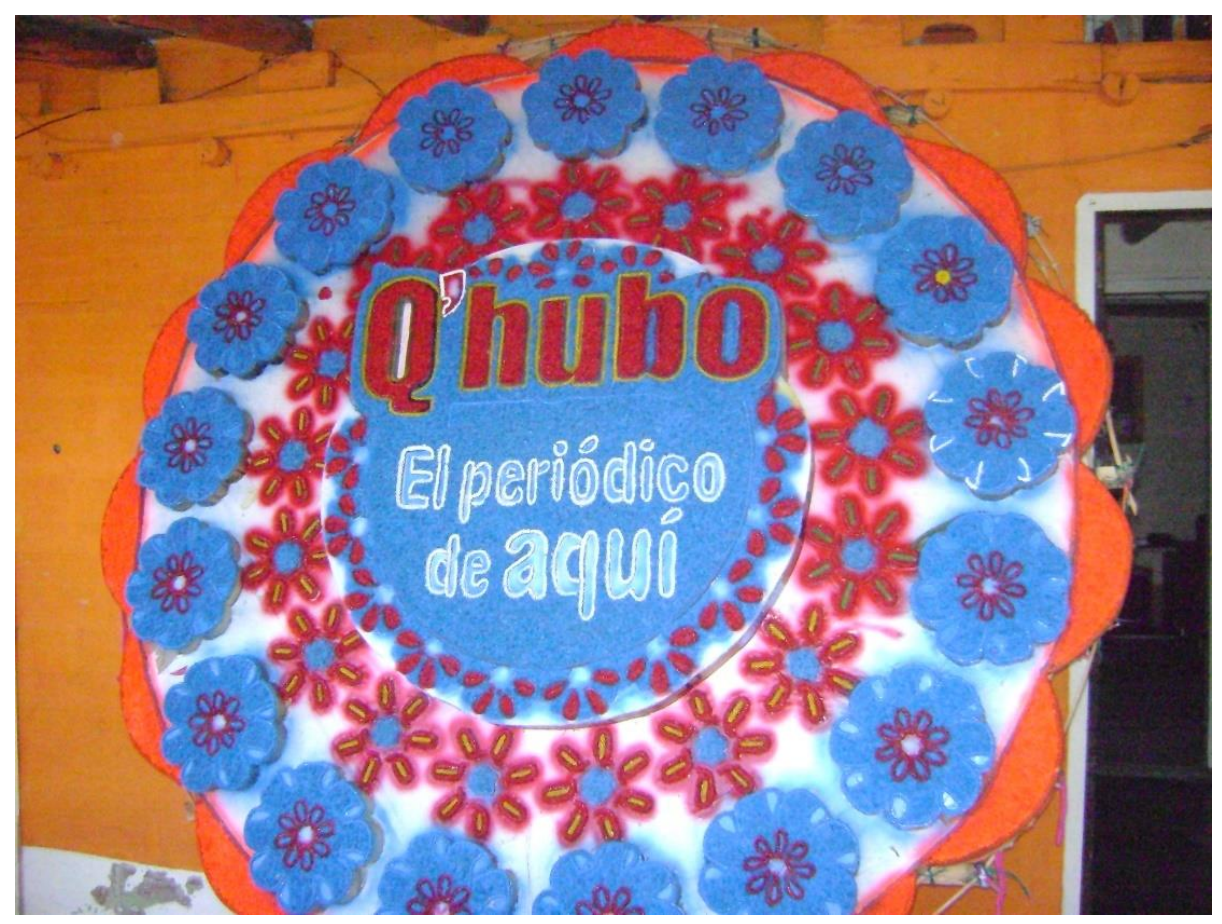

Santa Elena, agosto 9 de 2013. 


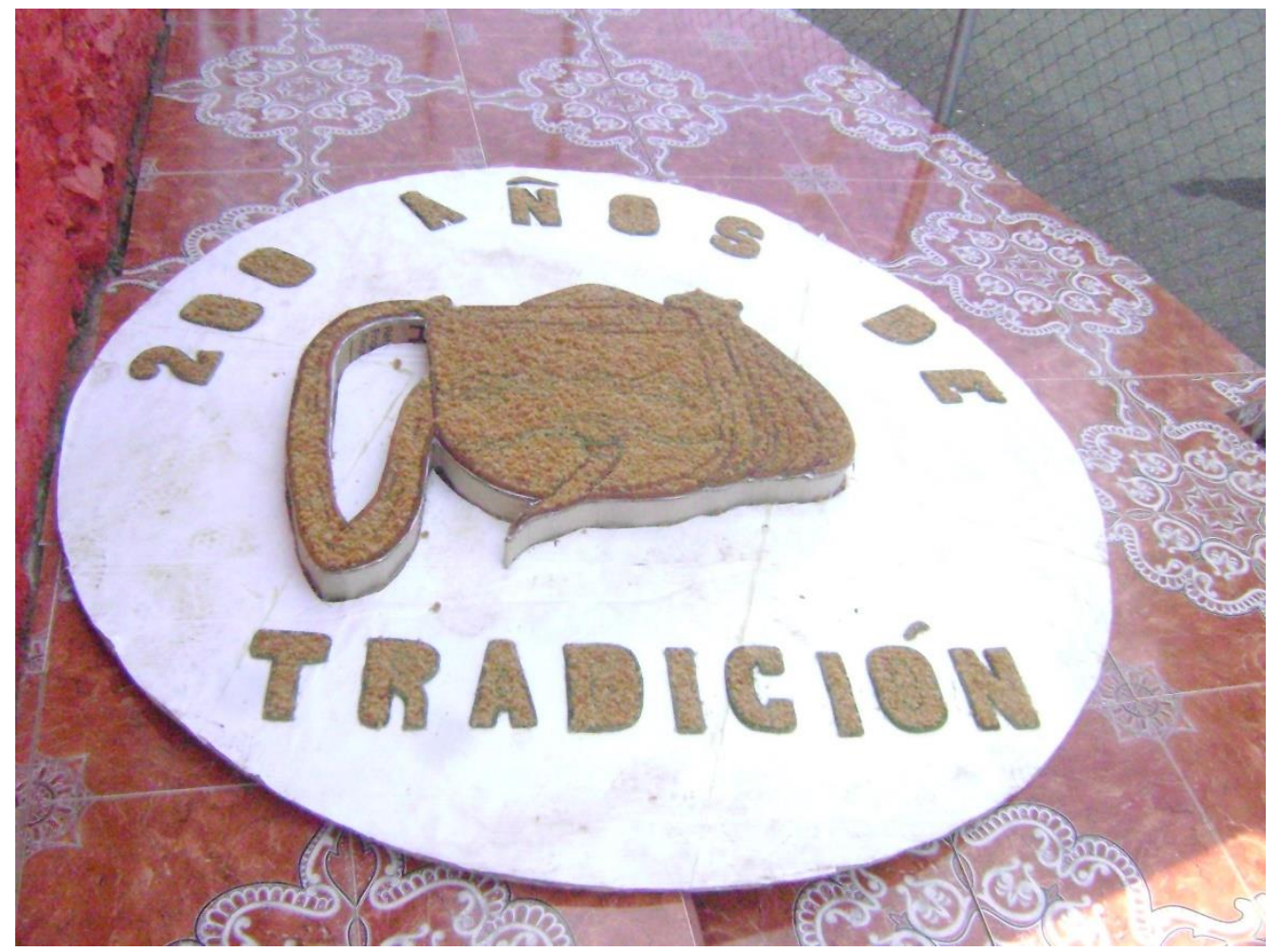

Santa Elena, agosto 9 de 2013.

A su alrededor pasan turistas con lentes oscuros y sombreros aguadeños que observan las creaciones tras ser atraídos por un niño que les invita a entrar desde la carretera, una vez allí les deja en el patio de la casa, donde se construyen las silletas. La madre de los silleteros y abuela del menor sonríe a los recién llegados, le muestra los triunfos de sus hijos, las figuras que usará uno de ellos en la silleta emblemática y convida a tomarse una foto con el diseño de la silleta que todavía está en fase de construcción. En el fondo del patio hay una mesa con productos típicos como solteritas, así como bebidas gaseosas, cervezas y papas fritas para la venta, pues ya que no cobran por la visita intentan conseguir algún beneficio que aporte a la economía familiar.

Siguen entrando y saliendo personas, que retoman la caminata y se dirigen a la vía principal, pero siguiendo el mismo camino en piedra hacía arriba dicen que hay más silletas, así que la siguiente casa, sin ningún turista merodeando y con un jardín en el que sobresalen los cartuchos blancos, hay un silletero adulto que en silencio construye su silleta, por lo que puede intuirse a primera vista es tradicional por la armazón y las flores frescas que hay cortadas a su lado. No permite fotos o grabaciones, tampoco habla mucho y contesta a cada pregunta brevemente, así 
que cuenta cómo hace intercambios de flores con sus vecinos y carga su silleta como parte de una tradición, no para ganar, pues asegura que competir con este tipo de silleta cada vez es más difícil.

Guillermo Londoño se refiere a la manera en que él construye su silleta durante la antesala al desfile, ayudado por su hijo, quien además se encarga de controlar la entrada y salida de los visitantes que llegan a su casa:

"Primero se hace la armazón en madera. Viene mi hijo con dos o tres amigos que se dejen llevar, juiciosos obedientes y atiendan las instrucciones de lo que se debe hacer. Porque mi trabajo es estar pendiente de la silleta porque esa es $\mathrm{mi}$ responsabilidad, ellos me ayudan en toda esa parte y con las indicaciones que yo les voy dando, y a atender la gente, que aquí la gente que viene es mucha, a estar pendientes de la silleta, de las flores, de la casa, de la finca, de todo, aquí hay que cuidarlo todo. Esta es una silla de una silleta muy pequeña, nosotros armamos una silleta de $2 \times 2.30$, que es la medida que tenemos establecida para silletas comerciales, pero el modelo y el tipo es este exactamente. Este material es chusco, familiar del bambú, es más duro. Sobre él se ponen las ramas del pino, del ciprés, como el follaje, y ahí se coloca el logo sobre el cartón ya puesto, instalado y se amarra muy bien y luego empiezan las decoraciones. Esta es una silleta monumental, el armario aplica para las dos, pero es monumental porque las flores van puestas, usted ve una gran variedad de flores muy bonitas es para la silleta monumental que también debemos hacer una acá para el programa turístico, porque debemos tener exhibidas por lo menos unas tres silletas. Ya estamos preparando todo para tenerlos ahí porque cuando vengan los grupos turísticos ellos tienen que tener la silleta aquí y la pueden cargar" (Entrevista personal a Londoño, julio 7 de 2012).

Otro silletero de nombre Joaquín, también explica cómo elabora su silleta y la manera en que vive las horas previas al desfile, sobre todo la noche anterior que dedica a terminarla al lado de su familia, tal como lo hacen la mayoría de sus compañeros de desfile:

"En mi casa empezamos un mes antes a buscar la madera, el musgo, el helecho, para que este todo livianito, el armario lo empezamos a hacer 15 días antes. Y las flores las ponemos un día antes y en la noche. Yo soy uno de los que en mi casa se recoge toda la familia conmigo y amanecemos, yo me acuesto por ahí a las 3 de la mañana. Mis hermanos, mi sobrino, mi mamá, primos hermanos. Yo soy como el más contento de la casa. Tres hermanos hacemos las silletas juntos, hay otro que vive más retirado y él no, y yo a todos les ayudo. El sembrado cuando lo tengo bien me alcanza para la silleta y para vender. El año pasado una señora no le alcanzaron las flores como a las 9 y me dijo don Joaquín usted tiene unos ramitos y yo claro, y fuimos y cogimos 20 ramos de flores y se las vendimos. Hay muchos que tienen cultivo y muchos que compran las flores, pero la Corporación de 
Silleteras ha abierto mucho las puertas para que cada silletero tenga su cultivo, en eso nos ha ayudado mucho". (Entrevista personal a Joaquín, mayo 12 de 2012).

Continuando con la observación, después de dejar al silletero que no permitió hacer fotos, el recorrido continúa subiendo la cuesta, en la que ya no hay silletas a la vista y tampoco turistas. La siguiente está en una vivienda de dos plantas con un moderno auto estacionado a su lado, un colorido jardín en frente y en el que puede verse un armazón en el corredor. Una niña que pregunta por la razón de la visita llama a su madre, que sin mucha gana explica que es la silleta de su esposo que en este momento no se encuentra y que seguro en la noche empezará a construir. También dice que varios hermanos de su marido participan en el desfile, pero que todavía no han empezado y tampoco están en sus casas.

Así que es el momento de regresar y ver cómo va la "fiesta" en el centro de Santa Elena. Pero no sin antes caminar un poco más en la vereda, en la que además de los habitantes oriundos de la zona, pueden encontrarse pobladores de todo tipo de procedencias, pues en los últimos años el sector se ha convertido en un lugar perfecto para quienes buscan una vivienda campestre, donde haya tranquilidad, aire puro y no esté lejos de la ciudad: tal vez esa es la intención de un grupo de artistas que habitan la casa más colorida de Santa Elena, pues sus paredes son usadas como lienzo, ya que hace parte de un proyecto cultural al que han unido personas de todo el mundo, tal como es el caso de un actor argentino que podía verse desde la carretera haciendo malabares.

Al volver al centro ya estaba a punto de oscurecer, lo que atrajo más y más visitantes que no dejaban de bajarse de los autobuses públicos y se dirigían al tablado, por el que pasaron bandas y cantantes de música popular, así como grupos de danzas locales que presentaron al público bailes como el del machete, ante el que el público aplaudió especialmente. Además existía la posibilidad de tomar una michelada, ver cómo se construye una pequeña silleta por un vendedor de flores y escuchar otros conjuntos musicales que se paseaban ofreciendo un espectáculo itinerante.

Además de la observación, también es interesante ver cómo va quedando registrado este proceso cada año en los medios de comunicación, tal como sucede con un artículo del periódico El Colombiano del 8 de agosto de 2013:

"Los silleteros de Santa Elena no solo tienen la responsabilidad de armar su silleta para el Desfile. Atender a los turistas y enseñarles sus tradiciones hace parte de la agenda de estos anfitriones.

La Twittercrónica visitó el corregimiento y algunas fincas silleteras, que aspiran a ser una alternativa turística durante todo el año. 
'Mi mamá fue quien nos enseñó a cargar la silleta. Ella lo hacía hace muchos años para vender plantas como ruda o musgo', le explicaba Joaquín Zapata a un grupo de unos 50 turistas, ansiosos por saber cómo se hace una silleta y conocer personalmente a los portadores de la tradición.

Joaquín, al igual que otros vecinos, están convirtiendo sus fincas en un referente para el disfrute y el aprendizaje de la cultura silletera. En nuestro recorrido, encontramos muchos turistas, entre extranjeros y antioqueños, atraídos por la belleza de las flores.

'La idea de los recorridos turísticos es que los silleteros puedan beneficiarse económicamente, mientras difunden la cultura silletera y hablan de su experiencia y sus propios cultivos', explica Lina Margarita Bayer, de la Corporación de Silleteros de Santa Elena.

Bayer aprovechó para invitar a los turistas a tener en cuenta las recomendaciones de los guías y campesinos en estos días de alto flujo de personas en el corregimiento.

'El sábado se forma aquí una congestión por el cierre de la vía. La gente debe subir temprano y debe hacerlo en transporte público, así se evitan complicaciones'” (Hernández Osorio, 2013).

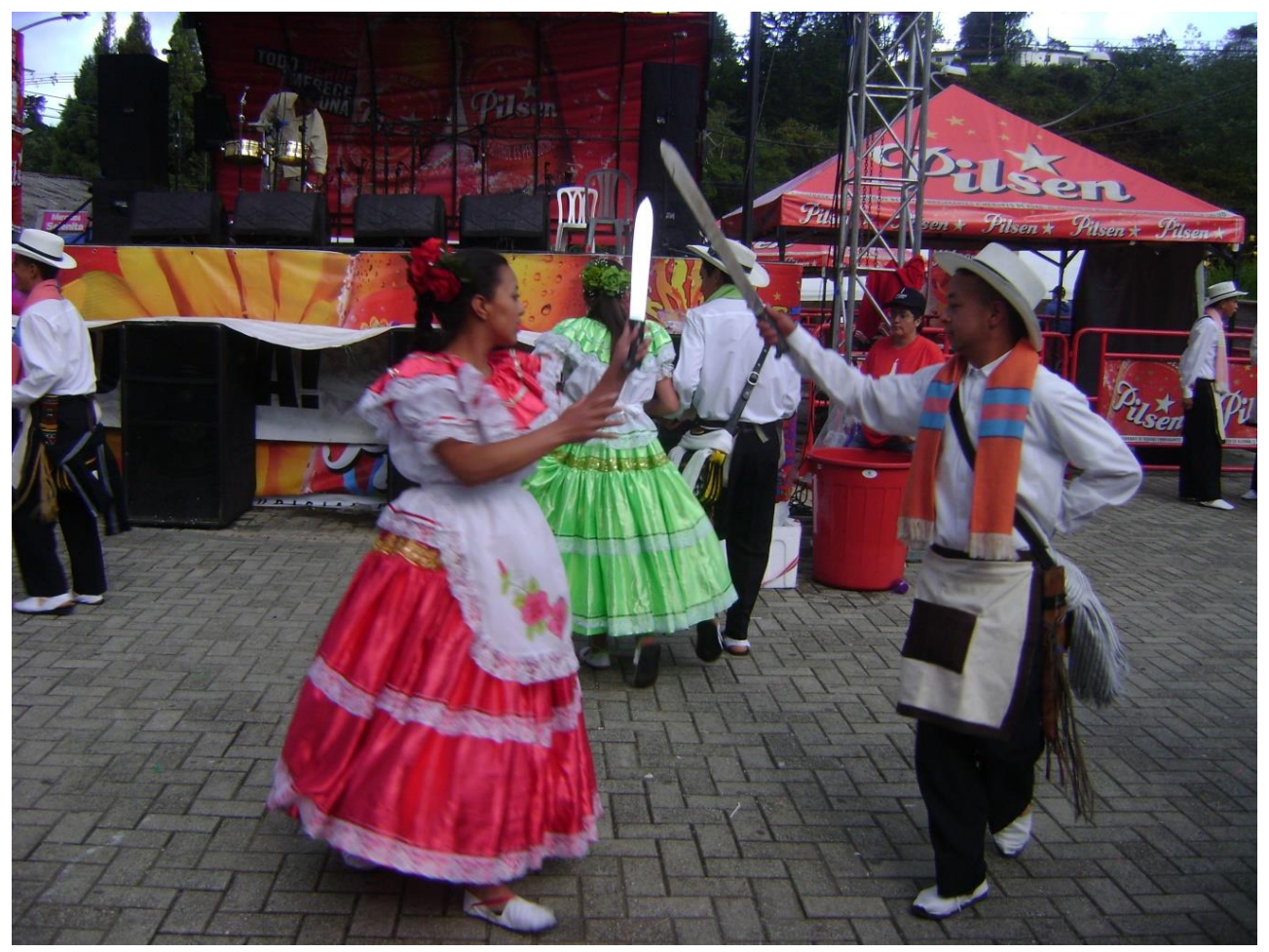

Santa Elena, agosto 9 de 2013. 
Esa noche muchos no duermen, algunos porque están terminando sus silletas, otros porque están atendiendo a los curiosos que visitan sus casas y algunos más justo porque, ya sea de finca en finca o de baile en baile, se quedan en Santa Elena a pasar la noche. Lo cierto es que para quienes esperan disfrutar con detalle de la parada del día siguiente, lo mejor es volver a casa, descansar y madrugar para conseguir un buen lugar entre la multitud.

\subsection{Desde el puente}

Como en los tiempos de sus antepasados, el día señalado en el calendario festivo de los antioqueños, los silleteros salen de sus casas cuando aún está oscuro en esta tierra en la que el sol se levanta entre las cinco y las seis de la mañana. A esa hora empiezan a subir los camiones que los transportarán hasta Medellín para participar en el desfile, que si bien inicia a las dos de la tarde y casi siempre se retrasa, presenta una agenda ocupada desde la mañana para sus protagonistas, que entre la movilización hasta el lugar del inicio, la evaluación de los jurados -que examinan las 500 silletas con detenimiento para poder dictaminar las ganadoras- $y$ la disposición del orden de la parada, apenas tienen tiempo de celebrar, felicitar a los triunfadores, dar alguna entrevista a los medios y resguardarse bajo la sombra de un árbol mientras empieza el evento.

Eso sí, deben tener tiempo para cumplir las normativas que desde hace varios años es necesario seguir para no ser excluidos de la competencia o el desfile, pues además de las especificaciones de cada silleta, también existen algunas reglas sobre el vestuario y la presentación personal, según cuenta Guillermo Londoño:

"Hay una historia que es como maluca y es que la gente era como muy desordenada, iban borrachos, no se ponían en orden correcto, no había mucho control con los silleteros, es que ahora es que estamos siendo estrictos, ahora es que se hace la prueba de alcoholemia, la alimentación, el transporte, los horarios, la clasificación, los órdenes, la presentación personal, a uno le revisan el sombrero, la camisa, el pantalón, el carriel, la taruma. Yo me voy muy ordenadito, pantalón negro, la cotiza, la camisa bien marcada, la ruana" (Entrevista personal a Londoño, julio 7 de 2012).

Algo similar explica Héctor de Jesús Ruíz Hernández, quien compara la actualidad del desfile con la época en la que empezó a participar en él, e incluso comenta la manera en que su padre perdió el contrato silletero por tomarse unos tragos de más:

"Mi papá desfiló varios años, después perdió el contratico por cuestiones a ver como irresponsabilidad, porque en ese entonces se tomaban el aguardientico y todo, probablemente hacían desorden, entonces bueno, varias cosas que hoy 
hemos tenido muy en cuenta, por ejemplo eso es lo que ya nos satisface también que la gente ya hemos aprendido como una nueva cultura del desfile de silleteros, cuál ha sido, yo me acuerdo que cuando yo empecé había mucho desorden en el desfile porque no voy a decir que yo tampoco, casi que la mayoría de los silleteros bajábamos con traguitos, borrachitos, fuera de eso en Medellín bebíamos aguardiente y todo, cuando salíamos a desfilar ya salían unos trastabillando con la silleta, eso se fue viendo una cosa de pronto desordenada que no era como lo común para nosotros satisfacer el turismo, entonces debido a que nosotros que ya hemos sido movidos por asociaciones, comités, se fue mirando desde ese punto de vista que era lo que íbamos a hacer, que ese desorden había que quitarlo, Fomento y Turismo empezó con eso, de pronto a ellos eso se le salía de las manos, pero ya entre medio de comités y todo se fue organizando la cuestión a que no hubieran borrachos y que no hubiera tanto desorden, eso ya llevamos en eso por ahí unos 11 o 12 años en ese trabajo, pero lo hemos venido a mejorar desde hace unos 5 años para acá" (Entrevista personal a Ruíz, abril 7 de 2012).

Este testimonio es interesante en la medida que evidencia cómo las autoridades y organizadores del desfile pretenden moldear de alguna manera al silletero, tal como puede decirse que las administraciones de la ciudad han intentado hacer con Medellín, es decir, es necesario que el personaje representativo de la región esté acorde a esa cultura paisa a la que ya nos referimos, a esa "raza" especial, para lo cual será necesario que controle rasgos más plebeyos y disruptivos como su estrecha relación con el licor bastante notable durante el trabajo de campo, las entrevistas-, de manera que sea posible una tradición mejor acoplada a la imagen de esa nueva Medellín, que además de hermosa, colorida y exuberante, también es moderna, civilizada, contenida y ordenada.

Jorge Robledo Ortiz, llamado el "poeta de la raza" y quien escribió numerosas publicaciones y creaciones literarias dedicadas a Antioquia, ya evidenciaba en sus textos algunas de esas características poco armoniosas con las del paisa arquetípico. En "El retrato del paisa" por ejemplo deja ver una relación muy marcada con el licor, la fiesta y el conflicto derivado de dicha mezcla, rasgos ocultos en las versiones oficiales del imaginario paisa, pero que siguen surgiendo en los testimonios y la cultura popular:

"Soy Antioqueño, visto de alpargatas, carriel y ruana montañera.

Tengo para el amor las serenatas y para los rivales mi barbera.

Ningún bambuco a mi guitarra escapa, $y$ en noches de jolgorio y de aguardiente solo respeto lo que diga el Papa, 
y tuteo hasta el mismo presidente.

Miro la Vida con desdén profundo

y es para mí tan chiquitico el mundo

que voy a pie de Guarne hasta el Japón.

A nadie envidio, quiero a una morena,

me emborracho cuando hay alguna pena

y llevo a Antioquia en el corazón".

Después de esta reflexión, es necesario volver al desfile y pensar en la presentación de la silleta, que no solo determina el pago del contrato y adquisición de la misma por parte de la Alcaldía de Medellín sino también su facultad para concursar y tal vez llevarse alguno de los galardones del día, con los cuales se premia a los mejores lugares de cada categoría y a la gran ganadora de la tarde. Es el momento en que cada silletero demuestra su creatividad y trata de conquistar al jurado con sus flores, como asegura Guillermo Londoño, quien lleva una silleta comercial:

"Sobre todo la parte decorativa es muy importante, es la que llama la atención y realza la silleta, sin dejar de lado el logo porque debe ir tal cual, es una revisión detallada la que se hace a la hora de la evaluación. Es muy minuciosa esa revisión, las medidas también son muy estrictas, esa parte decorativa es muy importante, a mí me gusta cada año hacer algo distinto, decorar cada día mejor, este año hay algo que espero me funcione que es absolutamente novedoso". (Entrevista personal, junio 9 de 2012).

Así que una vez en la ciudad y tras el desayuno ofrecido por los organizadores del evento, empieza el largo proceso de revisión por parte de los jurados, que suelen ser expertos en áreas como la cultura, las artes plásticas, la floricultura, así como diferentes exponentes del folclor colombiano. Ellos dan un listado inicial de semifinalistas entre los que eligen el ganador de cada categoría: niños, junior, monumental, emblemática, tradicional y comercial, y el ganador absoluto de la jornada. En 2013 ese honor se lo llevó Mauricio Londoño, quien concursó con una silleta monumental con figuras en movimiento, en la que quiso representar cada una de las nueve subregiones en las que está dividido el departamento, según explicó al periódico El Colombiano, con diferentes símbolos de cada una y denominada "Antioquia, la mejor esquina de América":

"Sobre esta base podemos ver la zona del Norte que se caracteriza porque es lechería lo que se maneja, aquí por ejemplo tenemos la zona de occidente donde tenemos el Puente de Occidente, donde vemos una pequeña recua de mulas atravesando el puente, porque resulta que cuando se inauguró fue así como lo hicieron, en la zona del Suroeste tenemos la zona cafetera que lo tengo representado en este Jeep Willys que se levanta hacia atrás por su propio peso, 
por el peso del café, aquí el Valle de Aburrá está representado por un silletero, que da la vuelta, en la zona del bajo cauca, ganado de carne [...] la zona del Nordeste, que es básicamente minería, tenemos un minero que entra y sale de un socavón como lo podemos apreciar en este momentico y en la Magdalena Medio que es la zona pesquera, tenemos este pescadorcito y el Oriente es la Piedra del Peñol con un cayac y la zona de Urabá que es está que son las bananeras propiamente" (Carvajal, 2013).

No era la primera vez que este silletero ocupaba el primer lugar entre los 500 participantes del desfile, sin embargo saltó a abrazar a uno de sus compañeros cuando se supo ganador del premio a la mejor silleta monumental y la emoción fue aún mayor cuando escuchó su nombre como el del triunfador absoluto del día. Como ganador encabezó el desfile y fue el primero en llegar hasta la meta, en el centro de convenciones Plaza Mayor, donde además de felicitado y ovacionado atendió a los medios de comunicación con los que todavía no había hablado como Telemedellín o canal Caracol. Ante las cámaras se le ve sudoroso y agitado después de caminar con su silleta a cuestas los más de dos kilómetros de recorrido, pero igual de sonriente que cuando recibió el galardón: "la sacamos del estadio gracias a Dios como decimos", dijo al primero, mientras que al segundo manifestó, "es lo mejor que le puede pasar a uno como silletero y más ahora hermano que esto es de locos. Vea la gente como se emociona, uno también, yo vuelvo y digo que a uno lo que lo motiva es esto, la gente hermano".

Tras él pasaron uno a uno los 499 silleteros restantes de todas las edades que salieron desde el Puente de Guayaquil, caminaron por la avenida del Río, luego por la avenida San Juan y terminaron por la avenida Ferrocarril hasta llegar al Plaza Mayor, donde las silletas finalistas han sido exhibidas durante los últimos años y desde donde también se hace la distribución de las demás para que adornen diferentes espacios de la ciudad.

Mientras tanto, a lado y lado de la vía, miles de personas también madrugaron para conseguir el mejor lugar que les permitiera ver pasar a Antioquia en primera fila, como dice el famoso lema. Otros contaban con una entrada para las graderías puestas a lo largo del recorrido para disfrutar cómodamente y sin sacrificios el evento, boletos que podían estar incluidos en los paquetes turísticos silleteros, obtenerse gracias a una de las empresas patrocinadoras de la Feria -que tenían derecho a parte de las entradas- o adquirirse por 50 mil pesos unos días antes del desfile en los puntos autorizados.

Poner tribunas y de alguna forma "privatizar" el recorrido ha sido un tema de múltiples opiniones desde que se implementó hace más o menos una década, pues si bien busca controlar la asistencia de público y tener un evento más ordenado, vuelve de alguna manera a los inicios de la Feria de las Flores, cuando 
las actividades principales se hacían a puerta cerrada en los clubes de la ciudad y el pueblo no podía participar. Así que aparte de dar privilegios a quienes pueden pagar o tienen cierta influencia, también disminuye la posibilidad de que la ciudadanía presencie esta fiesta popular, ya que los palcos han mermado considerablemente el espacio público para disfrutar la parada de manera gratuita.

El silletero fundador Jhon Londoño recuerda con nostalgia la época en que el que el desfile era totalmente libre y todos tenían la misma oportunidad para verlo, de manera que hace una crítica y un llamado a los organizadores del mismo para que distribuyan de mejor manera los beneficios económicos conseguidos con la venta de palcos:

"El gobierno, por parte del municipio de Medellín nos explota mucho, nos explota mucho, para que nosotros le demos a la región y al municipio de Medellín la belleza que tiene Antioquia por medio de Santa Elena y le llevemos al mundo la belleza que tiene Antioquia y que los gobiernos se lucren con eso, como se lucran. Por donde pasa el desfile ellos le cobran a la gente, y el turismo, eso ¿quién lo atrae?, el silletero" (Entrevista personal a Londoño, julio 7 de 2012).

Por eso, también resulta interesante observar el desfile desde un punto específico como cualquier turista sin palco. El lugar elegido fue el puente que une la estación del Metro Industriales con el centro comercial Punto Clave, donde también hay que llegar temprano para obtener la primera fila, pero gracias a la altura de la construcción es posible tener una buena vista llegando al medio día, siempre y cuando se resistan las más de dos horas que faltan para el paso de los silleteros bajo el potente sol que a esa hora cubre la ciudad. Sombrilla, agua embotellada, zapatos cómodos y bloqueador solar son las recomendaciones de los periódicos para asistir al evento, pues la espera suele ser larga y cada vez se hace más difícil con la cantidad de personas que tienen la misma intención de observar la parada.

Se escucha el sonido de helicópteros, del cielo caen pétalos de flores, hay sombreros por todas partes, vendedores de agua, paletas, raspao y cerveza para calmar la sed, pero también de mangos, frituras y otras golosinas que entretienen la demora del inicio. Los espectadores tienen sus cámaras fotográficas y de video preparadas, empujan discretamente al del lado para hacer espacio o "cuidan" el sitio de sus acompañantes estirando las manos o abriendo un poco las piernas. Lanzan gritos y aplauden cuando ven las primeras comparsas ubicadas en frente suyo y con ellas las silletas que empiezan a acomodarse en sus respectivos lugares. El ambiente se alegra mucho más cuando por fin empiezan a moverse: bailarines, danzas marciales, carrozas y grupos representativos de cultura popular colombiana, entre las que se cuentan representaciones de otras festividades nacionales como el Carnaval de negros y blancos de Pasto o el Carnaval de Barranquilla, así como varias alusiones a la idiosincrasia antioqueña. Pero el punto 
máximo de emotividad lo logran los primeros silleteros, que desde aquel puente parecen parte de una postal sacada de una fotografía de plano general desde arriba. No pueden verse los detalles como el movimiento del minero del Nordeste o del vehículo que carga café en el Suroeste de la silleta ganadora, tampoco se leen muy bien los mensajes de las emblemáticas o las caras de quienes las llevan, pero es una vista panorámica casi completa.

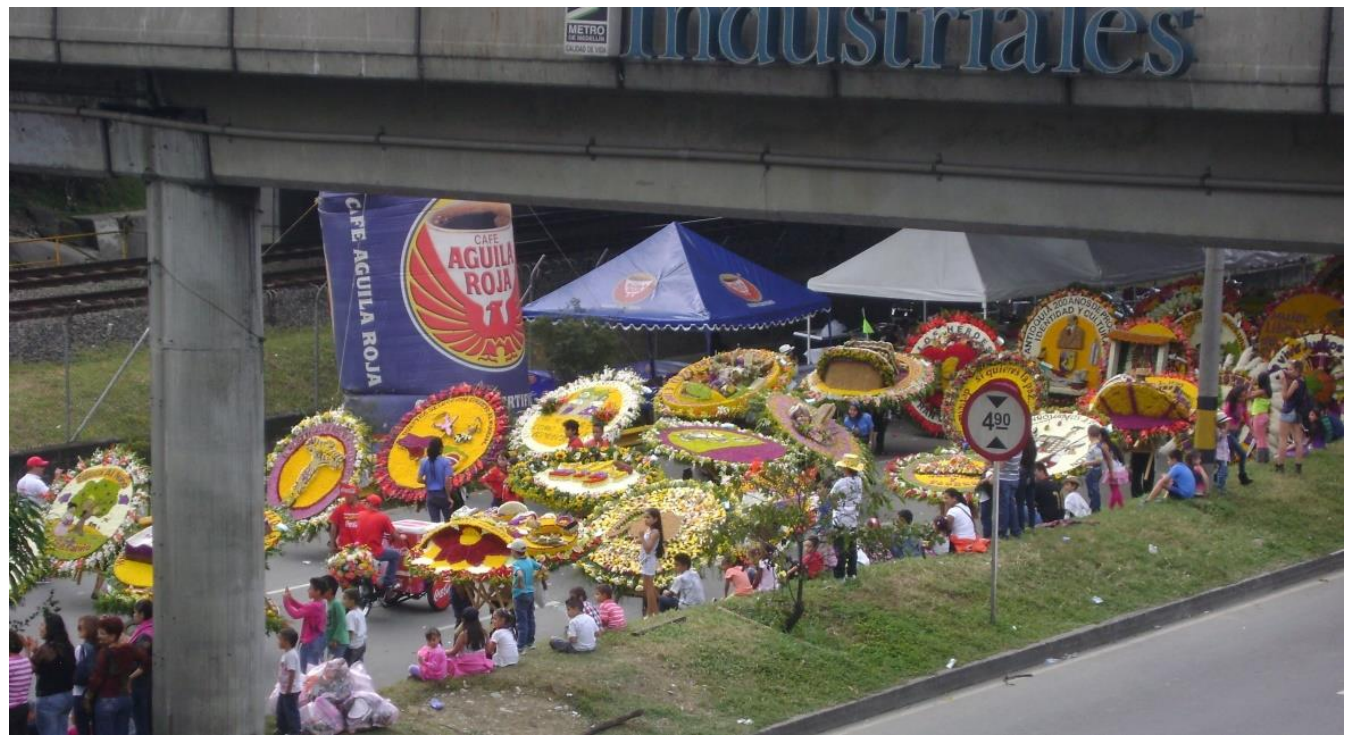

Medellín, agosto 11 de 2013.

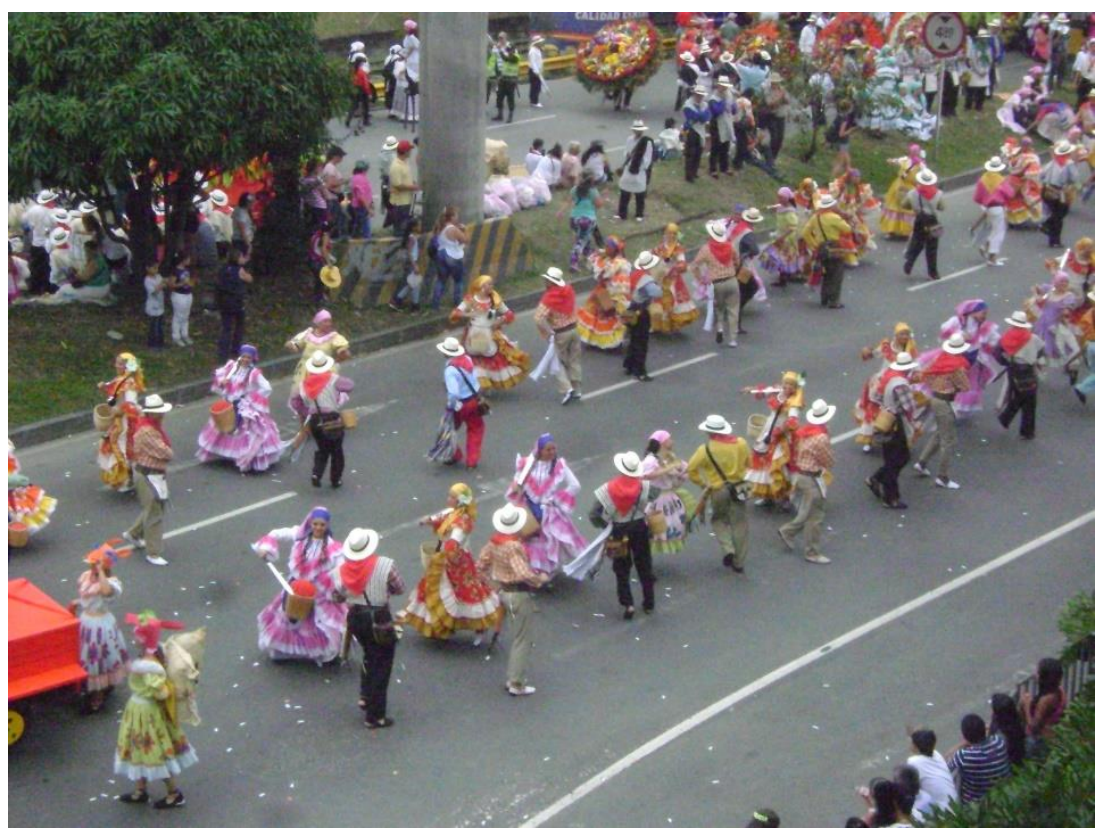

Medellín, agosto 11 de 2013. 
Policías y grupos de exploradores controlan el orden, pero no pueden hacer nada cuando una avalancha de personas, que deciden no respetar las vallas impuestas por los organizadores -para mantener alejados a los asistentes sin palco-, corren hasta la orilla de la avenida regional. Ahora si están en primera primerísima fila, justo por donde pasan los campesinos de Santa Elena cargados con sus obras de arte, sonriendo, dando la popular "vueltica" y pidiendo más aplausos. Al primer grupo siguió un segundo y un tercero, hasta que en el puente solo quedaron los que llegaron de últimos, de manera que los más madrugadores vieron recompensada su espera con una visión tan cercana que les permitió mirar a los ojos a los silleteros, bailar de cerca con las comparsas y tener fotos de primer plano. Las autoridades correspondientes no hacen nada más, pero la gente tampoco causa daño alguno, solo quieren ver de cerca a los más emblemáticos representantes de la cultura paisa. Por eso, los gritos y las ovaciones de la multitud son enormes y la emoción que se siente al ver de cerca esas pieles quemadas por el sol y ese calzado sencillo con el que sostienen sus enormes cargas, hace que más de uno no pueda contener las lágrimas. La belleza de sus creaciones también parece mucho mayor cuando están sobre sus espaldas porque ver una silleta en un centro comercial o alguna exhibición, aún en Santa Elena, no es lo mismo que escuchar los elogios orgullosos, ver las miradas conmovidas e incluso presenciar el llanto alegre de quienes han esperado horas para verlos a lado y lado de la avenida Regional.

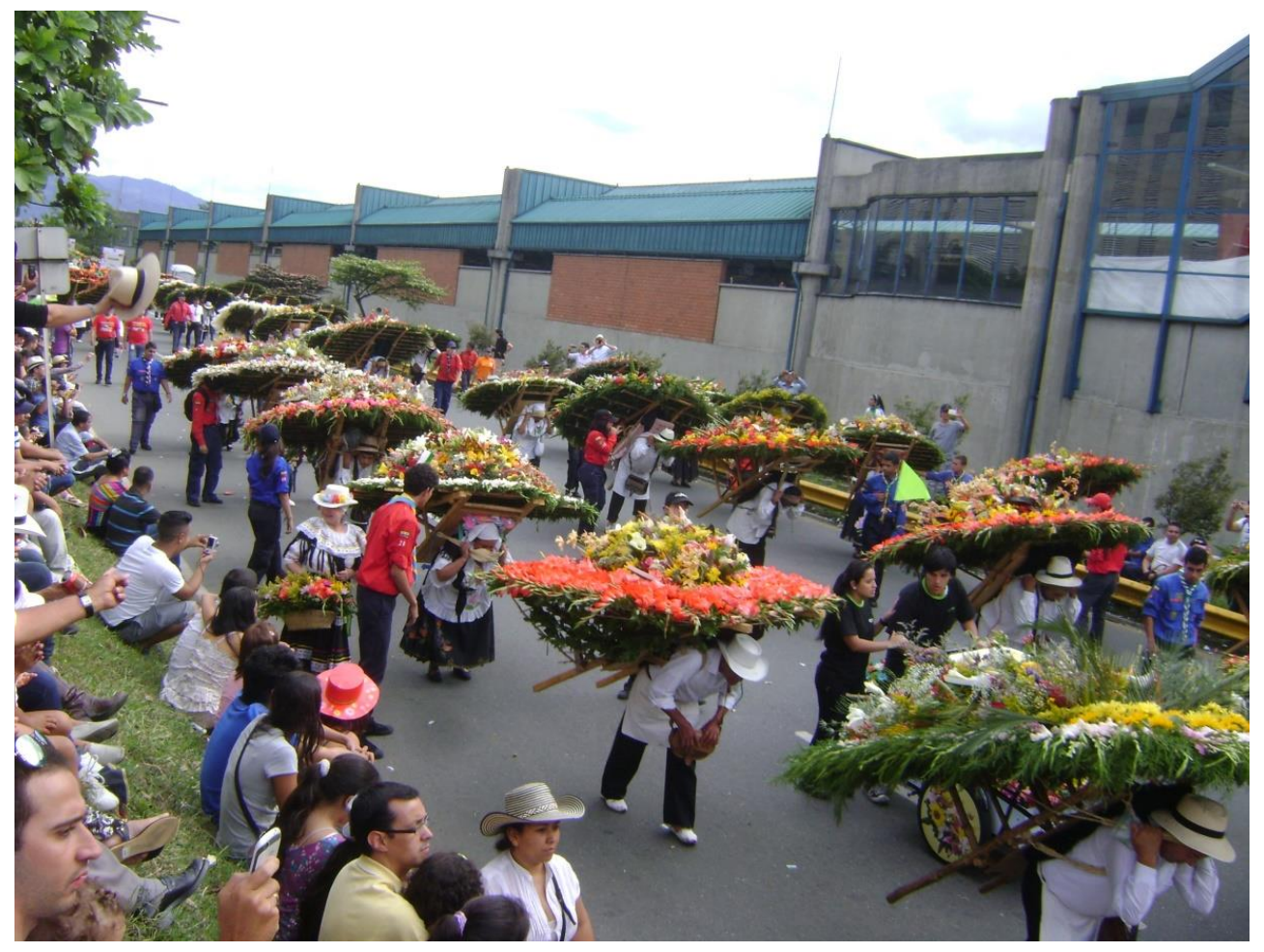

Medellín, agosto 11 de 2013. 
Es el caso de José Emiliano Puerta, antioqueño que vive en Caracas desde hace más de dos décadas y volvió para ver el desfile, trayendo varios de sus amigos venezolanos con él, según dijo a un periodista de El Colombiano ese día:

"Y la espera valió la pena. Casi cuatro horas bajo el sol, en medio de la multitud, no le importaron a José Emiliano Puerta, nacido en Copacabana pero residente en Caracas, desde hace 22 años. Él estaba en lo que quería: 'Viendo pasar la tierrita'.

Llegó hace tres días acompañado de un par de compañeros de trabajo. 'Les he hablado tantos años de la Feria de las Flores que este año me cogieron la caña'.

Mientras busca una sombra y revisa la cantidad de fotos que ha tomado, cuenta que esta experiencia no la cambia por nada. 'Es cuando me siento más feliz, vengo cada año a ver mis silleteros porque ellos son un orgullo para mí y mi familia. Mírelos, ¿no le parece que se merecen todo nuestro respeto?'" (Botero, 2013).

Si hay toda esa exaltación en el público, los protagonistas de la actividad más esperada de la feria están todavía más orgullosos y felices en su día, ya decía la periodista Gloria Valencia Diago (1974) en un artículo del 16 de agosto de 1974 que para ellos se trataba de un momento tan importante como si se tratara de su primera comunión o su matrimonio. Por eso, Guillermo Londoño describe así lo que pasa por su mente y su cuerpo mientras camina las calles de la ciudad llevando su silleta a cuestas:

"No saben ustedes lo que uno siente allá en ese desfile, un cansancio el hijueputa, mamao, le duele la cabeza, pero una felicidad, recuerdo que los argentinos me abrazaban [...] y se tomaban fotos conmigo, entonces uno ve la felicidad y la admiración de la gente y eso a uno lo conmueve, la alegría. Uno ve señoras que son muy sentimentales a punto de llorar, ustedes son unos verracos" (Entrevista personal a Londoño, junio 9 de 2012).

Héctor de Jesús Ruíz Hernández también relata su experiencia:

"Lo más agradable para nosotros es satisfacer la gente de Medellín, la gente linda que tiene Medellín, uno se siente muy orgulloso cuando llega allá y todo el mundo lo aplaude y uno va con la silletica y dese vueltica y tal, para uno es muy lindo eso, eso es muy relajante, muy bueno, a pesar del cansancio y del trasnocho uno se siente como grande en ese momento, ese es como el orgullo y lo que llevamos en el corazón" (Entrevista personal a Ruíz, 7 de abril de 2012).

Joaquín Emilio Zapata, dice no sentir cansancio y estar muy a gusto en el desfile, pero reconoce que la hora del mismo debería ser un poco más temprano, como se hacía antes, pues resulta una jornada muy agotadora para los silleteros: 
"Ojalá el desfile volviera a ser a las 11 de la mañana porque uno tan tarde ya está muy cansado y desgastado. Amanece haciendo una silleta, duerme una o dos horitas y lo coge ese sueño allá. Como era antes, a las 11 y terminaba como a las 2 , el año pasado empezó casi a las 4 y se acabó a las 7 , ya uno vuelve muy cansado. A mí no me parece duro el desfile, lo malo es que sea hasta tan tarde. A uno lo atienden muy bien cuando uno baja a Medellín, cuando van a la casa esa gente es muy atento. Todos son muy formales y muy atentos con uno" (Entrevista personal a Zapata, abril 7 de 2012).

Al día siguiente podían leerse testimonios similares, aunque mucho más breves, en los periódicos del país, pues la parte más larga solio estar dedicada a las cifras del desfile y de la fiesta, que casi siempre deja su emblemático desfile para el final. En esta oportunidad los medios hablaron por ejemplo de 700 mil asistentes a la parada, entre los que se cuentan 15.849 visitantes, 6.450 extranjeros, lo que equivalió a un crecimiento de más del 40 por ciento, además de 20 mil lugares en los palcos, solo 5 mil de ellos vendidos al público en general.

Entre las crónicas y noticias del día, vale la pena replicar parte de la que publicó El Tiempo un día antes de la jornada, anunciando un poco el recorrido del día siguiente, en el que destaca lo especial de la fecha, en la que también se celebraban dos siglos de la independencia del departamento:

"Con siete componentes temáticos que van desde los levantamientos populares, pasando por las comunidades indígenas y afrocolombianas, la historia del ferrocarril de Antioquia, la industrialización, el café y la arriería, hasta la ciudad de más innovadora, la edición del 56 del desfile de silleteros rendirá este año un homenaje a los 200 años de la Independencia de Antioquia" (Vélez, 2013).

\subsection{Desde la televisión}

"Cuando hemos estado sumidos en la más absoluta oscuridad, la cultura ha sido la salida", (Presentadora transmisión Desfile de Silleteros, 2012).

Para tener un punto de vista complementario y un poco más panorámico de la observación hecha, tanto en Santa Elena como durante el desfile por las calles de la ciudad desde un punto específico, también se hará un relato de la transmisión televisiva del desfile del 7 de agosto de 2012, en el que podrá conocerse con más detalle el orden de la parada por ejemplo y los comentarios de presentadores y "expertos" invitados, encargados de dar otra versión del evento a quienes no pudieron asistir.

La tarima de las dos presentadoras, una de Teleantioquia y otra de Telemedellín los dos canales locales y gubernamentales- este año estaba ubicada en el cubo del edificio de las Empresas Públicas de Medellín, punto cercano al espacio donde 
reposarían las 30 silletas finalistas. Desde allí comentaron la parada acompañadas por el ex ministro de cultura y jurado del desfile, Juan Luis Mejía, y la presidenta de la corporación Familia Londoño, la silletera Carmen Cecilia Londoño Londoño.

Un total de 12 comparsas, dos internacionales y una decena nacional, más de dos kilómetros de recorrido y 500 silleteros de 17 veredas, son algunos de los números con los que empezó la transmisión, que este año tuvo participación de ambos canales, tras varias polémicas en 2010 por un cambio en la comercialización y producción del evento. Dicho año, la cobertura televisiva, que era realizada por Teleantioquia, pasó a encargarse a Telemedellín, hecho que le generó pérdidas por \$137 millones al primero, según información del periódico El Mundo del 6 de agosto de 2010 (Álvarez, 2010). En 2010 volvió a compartir realización.

Mientras pasan los agentes de policía que encabezan el desfile, de los cuales las periodistas dicen que son 520 a lo largo de todo el recorrido y que están apoyados por 325 gestores universitarios, el ex ministro habla sobre los inicios de la parada y la evolución que ha tenido, teniendo en cuenta que se trata de un "patrimonio vivo" como él lo llama, que "no lo puedes congelar en una burbuja o en una capsula de cristal como el patrimonio material sino que hay que permitir que la sociedad vaya evolucionando":

"Primero se hizo por la carrera Junín, fue el primer desfile en 1957, luego durante muchos años se realizó a lo largo de la avenida la playa, luego se hizo por la oriental, luego por San Juan y ahora este recorrido que me parece mucho más compatible y más fácil para los silleteros (por la Regional), ya no hay que subir el puente por ejemplo que costaba tanto con esa carga tan grande que llevan ellos, me parece que este es mucho más amable, y estilísticamente me parece que hemos ido recuperando una tradición sobre todo en la tradicional, en ella encontramos otra vez toda la flora de Santa Elena expresada en las silletas y me gusta mucho cierta evolución que se ha dado tanto en la monumental como en la emblemática, poco a poco se le va incorporando por ejemplo la tridimensionalidad, hoy vimos por primera vez algunas con movimiento".

Los uniformados continúan pasando, los asistentes siguen a la expectativa del paso de los protagonistas del desfile bajo el soleado día y en la tarima de televisión empieza a hablar la silletera invitada, quien enfatiza su participación en la parada desde que tenía 10 años, su pertenencia a una de las familias más tradicionales, a la que llama "ganadora de ganadores" y la creación de una de las corporaciones más influyentes de Santa Elena, en la que a lo largo de todo el año se realizan todo tipo de actividades con el objetivo de que no sea necesario esperar hasta agosto para que propios y turistas puedan vivir de cerca la cultura silletera, dentro de las cuales se incluye la atención en varios idiomas: 
"Hacemos charlas silleteras, en Semana Santa hacemos Semana Santa de flores [...] trabajamos con todos los silleteros y silleteras que ya no desfilan el 7 de agosto, el viernes santo hacemos un trabajo muy bonito con estos campesinos, nosotros como corporación les colocamos las 11 estaciones que se realizan el viernes santo, nos venimos en viacrucis hasta la parroquia y ahí quedan exhibidas. Para la Navidad también hacemos todo lo que es la Navidad, cada silleta representa un rey mago, la Navidad, el niño Jesús y también utilizamos familias que no desfilan el 7 de agosto aquí en Medellín. Otra cosa es que en las fincas silleteras atendemos personas que no pueden venir en la época de la Feria de las Flores y las atendemos en nuestras fincas, se les da una charla silletera muy completa, no solo contando la historia del desfile de silleteros sino desde la época prehispánica, nos pasamos por la colonia, llegamos al 1957 y empezamos a contar la evolución de la silleta desde la silleta tradicional hasta las silletas que hoy van a desfilar porque hoy venimos con silletas con movimiento artesanal".

La acción empieza con Barrio Comparsa, un grupo de mujeres con vestidos blancos, delantales amarillos y sombreros aguadeños, seguidas por hombres también de blanco, algunos con ponchos de color, otros con azadón que simulan arar. Se trata de un montaje llamado "Hijos del maíz" que buscaba hacer un homenaje a este producto como símbolo del continente y que es ideado y actuado por este colectivo conformado por un grupo de jóvenes, pertenecientes a barrios populares de Medellín

"Ellos se están preparando por mucho tiempo, es lo que pasa en los grandes carnavales del mundo, escogen ese tema y alrededor de ese tema escogen un vestuario, una coreografía, una música, es toda una alegoría a la siembra del maíz y como a través de la danza y la música se exalta y se valora este producto agrícola tan importante en América".

Y por fin el público ve desde lejos al ganador absoluto de 2012, Luis Alfonso Rabe, quien con su silleta tradicional logró conquistar a los jurados, rompiendo con el mito de que esta categoría no ganaba, una idea surgida porque hacía siete años que no se llevaba el máximo galardón. Es el momento en el que los dos invitados se refieren a la importancia de volver a las flores tradicionales y Mejía, como jurado del evento, alude a que "fuimos muy exigentes en el jurado con eso este año y esa nos llenó completamente de satisfacción, además es como el arquetipo del silletero antioqueño".

Londoño por su parte, asegura que el ganador "es un excelente líder, hace parte de la Corporación de Silleteros y siempre está en todas las reuniones que ellos ejecutan, entonces es un gran representante". Al mismo tiempo, la silletera también recordó el sentimiento que tienen los campesinos de Santa Elena, como ella, cuando se despiden de sus familias antes de partir al desfile, justo cuando suben los camiones a recogerlos y ella siente que es el momento de hacer gala 
del trabajo, "la despedida es algo tan especial que todo el mundo espera como ese momento porque es como la bendición para que les vaya muy bien aquí, antes, durante y después del recorrido".

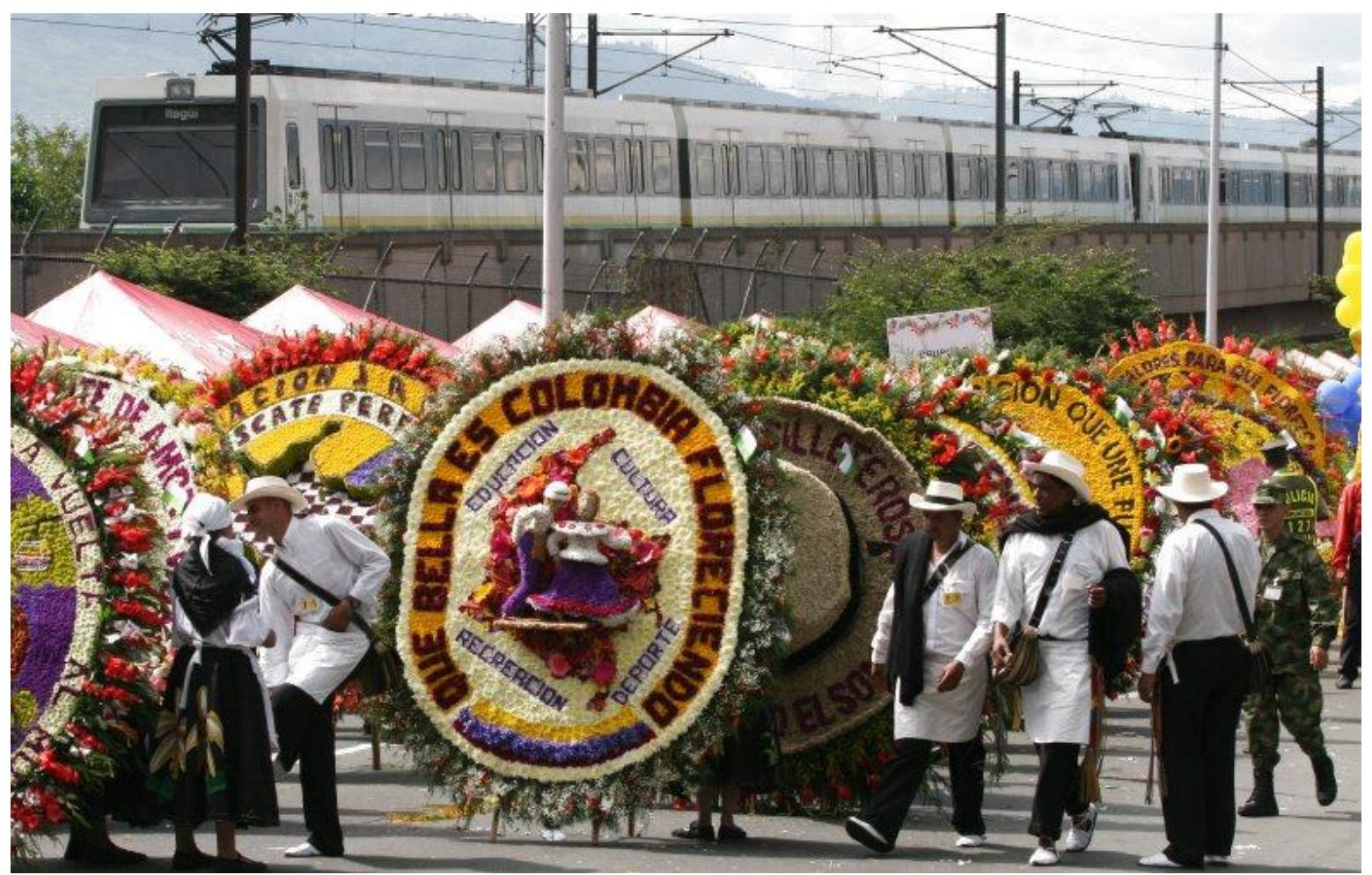

Fuente: Serrano, J.M. (2012, 5 de agosto). Blog Diagnostico Global de El Tiempo.

Más adelante continúa la ganadora de la silleta infantil, María Camila Soto Buitrago de 11 años, y tras ella los 30 niños que entre los 7 y 12 años llevan pequeñas silletas a sus espaldas y que a diferencia de los mayores, participan después de haber sido seleccionados en un sorteo que da la oportunidad de desfilar a 2 o 3 menores de cada vereda. Para Juan Luis Mejía, los pequeños son fundamentales para conservar la tradición:

"Los niños son lo más importante en esto que llamamos patrimonio inmaterial, es la transmisión de padres a hijos de toda una expresión cultural, eso es lo que hay que mantener, aquí no valoramos tanto un objeto sino todo ese proceso y esa transmisión que se hace de generación en generación, ese es el gran valor de este desfile".

Tras el paso de los herederos directos, continúan una serie de comparsas encabezadas por la Corporación la Polilla que este año trae una propuesta llamada "Flores en carnaval", que recurriendo a diferentes elementos propios de este tipo de festividades, rinden un homenaje al que se cree fuera el inicio de la Feria de las Flores y su alusión primaveral. A la cual le sigue una banda marcial, 
conjunto típico en las celebraciones antioqueñas y que siguiendo el ejemplo de las más populares del país, mezcla obras nacionales caribeñas con melodías clásicas y ritmos internacionales.

Estas agrupaciones dan paso a una de las participaciones más esperadas del día, la de los silleteros pioneros, que ya sea caminando con pequeñas silletas tradicionales a sus espaldas o en una carroza patrocinada, pues la mayoría dejaron el desfile debido a problemas de salud y no resisten el largo recorrido caminando, lanzan flores y besos al público que los saluda y elogia.

En medio de estas vistas, Mejía hace una reflexión interesante sobre la vida cultural de la ciudad y el surgimiento de varios grupos presentes en este desfile como una respuesta al pasado violento de Medellín:

"Varias comparsas que han pasado, Polilla, Nuestra Gente, Barrio Comparsa son una serie de Comparsas que han pasado son una serie de organizaciones que surgieron en la época más difícil de la ciudad, son una especie de resistencia cultural a una etapa de violencia, en la que una serie de muchachos se alzaron contra esa violencia y han agrupado una serie de muchachos que también se viene de generación en generación en los barrios de la ciudad, lo que está viviendo hoy es la alegría colectiva, hay 800 mil personas en las calles de Medellín participando de manera pacífica".

Pero los silleteros no paran, ya que es el turno de los jóvenes, denominados junior, un total de 40 participantes entre los 13 y 17 años, que sin la edad suficiente para tener un contrato también tienen la oportunidad de demostrar su amor por el legado de sus padres, abuelos y bisabuelos cargando a sus espaldas el elemento que a muchos de ellos les sirvió como herramienta de trabajo y base de su sustento económico. En primera fila va Tatiana Restrepo, la ganadora de la categoría, que existe desde 2005, pues tradicionalmente habían desfilado niños y adultos, pero había un vacío en estas edades, quienes si alguna vez habían participado en el desfile tras ganar el sorteo de los pequeños, tenían que esperar a ser mayores y obtener un contrato para poder volver.

Atrás siguen los portadores de las silletas tradicionales, esas estructuras que hacen un homenaje a los instrumentos que inspiraron la tradición y por lo tanto no solo tienen su misma estructura, sino que también van cargadas de flores nativas de Santa Elena, tal como en los tiempos del auge de la floricultura en el corregimiento. La mayoría de los participantes en el desfile pertenece a esta categoría, pues este año fueron 229 en total, entre ellas la ganadora absoluta.

El siguiente grupo en pasar es el del Carnaval de Negros y Blancos de Pasto, 45 artistas que representan el sur del país y la mezcla de sus culturas pacífica, 
andina y amazónica. Mientras la gente los ve pasar en las pantallas de sus televisores, la tarima principal da paso a una de sus reporteras entre el público, esta vez encargada de entrevistar al alcalde encargado de la ciudad, pues el principal se encuentra en Londres en los Juegos Olímpicos, donde trata de promocionar a la ciudad como candidata de los Juegos Olímpicos de la Juventud 2018, un "honor" que finalmente se llevó Buenos Aires:

"Estamos muy satisfechos, un evento lleno de color, de alegría, un homenaje a la vida, a las flores, los colores, esa es la feria que queremos para Medellín, una feria para disfrutar en familia, para vivir en familia, para privilegiar la vida como valor supremo [...] Representa un homenaje a la cultura antioqueña, a la cultura paisa, al colorido, a las flores tradicionales de Medellín, de Santa Elena, un tributo a la vida de los antioqueños, yo tengo que retomar las palabras de nuestro alcalde que está pidiendo a toda la sociedad de Medellín una alianza por la vida y por la equidad".

Después sigue el paso de las silletas emblemáticas. “¿Tú de qué lado estás?” es el mensaje que puede leerse en la que obtuvo el primer puesto, detrás van otras frases, algunas de denuncia como las que están en contra del maltrato a la mujer; otras de homenaje como las dedicadas al primer siglo de la muerte del escritor colombiano Rafael Pombo o a los 30 años del único nobel del país otorgado a García Márquez; o de expresiones populares que destacan el origen campesino del desfile y su pertenencia a la cultura paisa.

Vale la pena recordar las palabras de Mejía frente a este último tipo de mensajes, comentario que hizo a partir de una silleta de flores con los colores de la bandera colombiana: "es muy importante la incorporación de lo paisa a la nación, como nos integramos a través de un mapa de flores o como nos sentimos orgullosos de ser colombianos a través de unas expresiones artísticas y de la naturaleza. Me gustan mucho esas que muestran la integración del paisa al país".

En esa ocasión, la ganadora hace alusión a una campaña del gobierno departamental para promover la legalidad, de manera que la pregunta “¿Tú de qué lado estás?" hace referencia a la delgada línea que existe entre la legalidad y la ilegalidad y lo fácil que puede ser cruzarla, sobre todo tras el legado cultural dejado por el narcotráfico en la ciudad, del que tanto se ha ocupado esta tesis. Así que es interesante ver cómo en esta oportunidad el silletero se convirtió en un emisor directo de un mensaje transformador para la ciudad, pero que en este caso no puede negar su pasado y evidencia las huellas que todavía tiene en el presente, así que existe una mezcla de personaje tradicional, pero que no es ajeno a la actualidad, tal como lo confirma la silletera Londoño al explicar la manera en que se preparan este tipo de silletas en Santa Elena: "nos sentamos en familia y tomamos hechos relevantes del año", pues como también manifestó la presentadora, esta categoría busca "sensibilizar a la ciudadanía sobre su actuar 
en la sociedad", al tiempo que se centra en "temas religiosos, políticos, ambientales, educativos, de vida cotidiana, opinión y reflexión".

"Arrieros pues" es la comparsa que sigue a las silletas tradicionales, quienes en esta ocasión hacen un montaje en torno a "Orquídeas, pájaros y flores", una de las actividades más importantes de la feria de las flores y que consiste en una exhibición floral cerrada en el Jardín Botánico. Este grupo pertenece al corregimiento de San Cristóbal, el cual también se ha vinculado a las flores como explica Juan Luis Mejía:

"Eran las dos culatas que se llamaban en la época de la Colonia, la de San Cristóbal y la de Santa Elena, los dos extremos del Valle de Aburrá, uno más dedicado a la floricultura como tal Santa Elena, y San Cristóbal más dedicado a la horticultura, pero desde hace unos años vienen participando activamente en el desfile sobre todo con esta comparsa".

A continuación pasan las estructuras más grandes y pesadas de toda la parada, las 79 silletas monumentales que en 2012 demostraron la capacidad y resistencia de estos hombres y mujeres de Santa Elena. Enormes, llenas de color y con diseños tan creativos como la flor de flores que podía verse en las primeras líneas, son sin duda uno de los elementos más llamativos para el público, pues además de su tamaño, que entre follaje y follaje suma los dos metros y medio, permiten el uso de todas las variedades de flores colombianas sin límite, de manera que Londoño asegura que cada vez son más los silleteros que se inclinan por este tipo de silleta: "muchos silleteros de la tradicional se están pasando a la monumental porque les parece más impactante por la variedad de flores que les permite la silleta".

La Batucada Afro es el grupo que escolta a la categoría monumental y como una de las principales manifestaciones a la pluralidad cultural de Antioquia, poco expresada hasta el momento en el evento, vale la pena reproducir el comentario del ex ministro de cultura con relación a la variedad étnica del departamento y del país:

"Es una manifestación de esa Colombia multicultural, multiétnica y es un reconocimiento a esa cantidad de población afrocolombiana que vive en Medellín y en Antioquia y a través de esa expresión de la batucada, que es una expresión que viene de Brasil, pero que se une a la chirimía del Atrato, entonces es una presencia de esa Colombia multicultural y multiétnica en ese desfile de silleteros que es un reconocimiento a que somos diversos, somos distintos y que debemos convivir de una manera armónica desde cada una de esas expresiones culturales".

La transmisión se va de la tarima principal otra vez al público, esta vez para entrevistar a doña Mariela, una señora que acompañada por su hija y su nieta dice 
estar al lado del camino de los silleteros desde las 9:00 de la mañana, con el fin de "estar de primera mirando la cultura paisa de nuestra Medellín", pues asegura que "soy paisa y me siento orgullosa". Entre la multitud también está doña Carmen, que da su testimonio más adelante en la transmisión y dice haber llegado una hora antes que doña Mariela, pues "al que madruga, Dios le ayuda" y después de felicitar a todos los antioqueños por "las maravillas" y "las bellezas" que hacen, también dice que "es maravilloso que vengan de otros países a conocer esta belleza de desfile de flores, no hay palabras para decir, nadie podrá decir que esto es feo".

Y al regresar al sitio donde se encuentran los invitados principales es la hora de hablar de la historia de la parada, contada por Mejía, con un relato muy similar al que se maneja desde la oficialidad y con un énfasis en el uso de la silleta como herramienta en prácticamente todo el continente americano, pues comenta que hace poco trajo algunas fotografías de México donde encontró que esta práctica era popular:

"En la época de la colonia había caminos tan difíciles que ni la mula ni los bueyes podían circular, entonces se originó la profesión de silletero, carguero, peón de estribo, peón de tercio como se llamaban y ellos eran los que transportaban sobre todo entre la meseta del Oriente y el río Magdalena pasajeros o mercancías, se llamaban cargueros de líchigo, pero ya cuando entran las formas modernas de transporte, el automóvil, el ferrocarril, etc., esta silleta es utilizada por los campesinos de Santa Elena para bajar las flores que ellos cultivaban y que vendían de casa en casa en Medellín, en los atrios de las iglesias, en los cementerios y esa es la tradición original, esa silleta que originalmente se usó para llevar personas o carga hoy se usa es para transportar flores, de manera que ese es el origen de la tradición silletera y por eso es tan importante mantenerla".

Es interesante ver cómo Mejía se refiere a los orígenes como muchos otros para insistir en la "importancia" de la tradición silletera y se refiere a la necesidad de "mantenerla", pero no da explicación alguna sobre el tema más allá que la relevancia de sus inicios. Otra vez se evidencia el vacío a la hora de abordar la manera en que el desfile llegó a convertirse en una representación de lo antioqueño, en las razones que sustentan la necesidad de conservación que tanto se pregona y tras las que puede verse un interés por establecer una "tradición" conforme a las necesidades de imagen de la ciudad. Por eso, es necesario "adecuarla" y borrar todo rastro indeseable al interior de la misma -el caso del licor que ingerían los silleteros mientras bajaban a Medellín- para lograr una tradición digna de los "valores paisas" de antaño, tal como lo hizo la nueva Medellín con su pasado reciente en pro de su famosa recuperación. Preservar la tradición en el caso del evento principal de la Feria de las Flores busca en gran medida atraer 
turistas e inversión externa, pero sobre todo busca reinventar un pasado bello que confronte con el pasado reciente de violencia que se pretende olvidar.

Volviendo a la descripción de la transmisión televisiva del desfile, tras el paso de la Banda de Baranoa, una de las más relevantes del país dentro del esquema de bandas marciales y militares -a los aires tropicales y caribeños de su región (Costa Atlántica colombiana) le incorporaron los abanderados, personajes típicos de los carnavales europeos-, se pueden empezar a ver los logos en flores de las empresas más importantes del país, que también quieren hacerse publicidad y destacarse dentro de la feria más popular de uno de los centros económicos de Colombia. Se trata de 50 silletas comerciales, que también son contratadas por medio de la Corporación de Silleteros como en el caso de las demás, pero que son pagadas a un precio más alto por tratarse de un patrocinio privado. En esta categoría lo más importante es la rigurosidad en la construcción del logotipo, de manera que quede lo más similar posible al original, así que en este caso las reglas son más flexibles en cuanto al uso de materiales, pues es posible por ejemplo recurrir a flores pintadas para conseguir el mismo color del símbolo empresarial.

Y tras ver el último tipo de silleta, el desfile empieza a llegar a su final, aunque después vienen los perros del refugio La Perla, más bandas marciales, incluidas las del Ejército y la Policía, así como los perros policía que arrastran pequeñas silletas gracias a un par de ruedas adecuadas. Los verdaderos protagonistas de la jornada ya han empezado a llegar a su destino final y con ellos sus silletas, que quedarán exhibidas en el principal centro de convenciones de la ciudad siempre y cuando hayan hecho parte de las 30 finalistas, mientras que las demás reposarán en diferentes espacios de la ciudad para que sus habitantes no olviden a esos campesinos que las cargaron una vez más y que volverán el próximo año a caminar, dar "la vueltica" y conmover al público con la añoranza que su figura hace a esos supuestos "tiempos mejores" que vivieron los paisas porque como concluye Mejía, "el gran mensaje que nos deja esta feria de las flores es que esta es una sociedad que puede vivir en perfecta armonía y perfecta paz". 


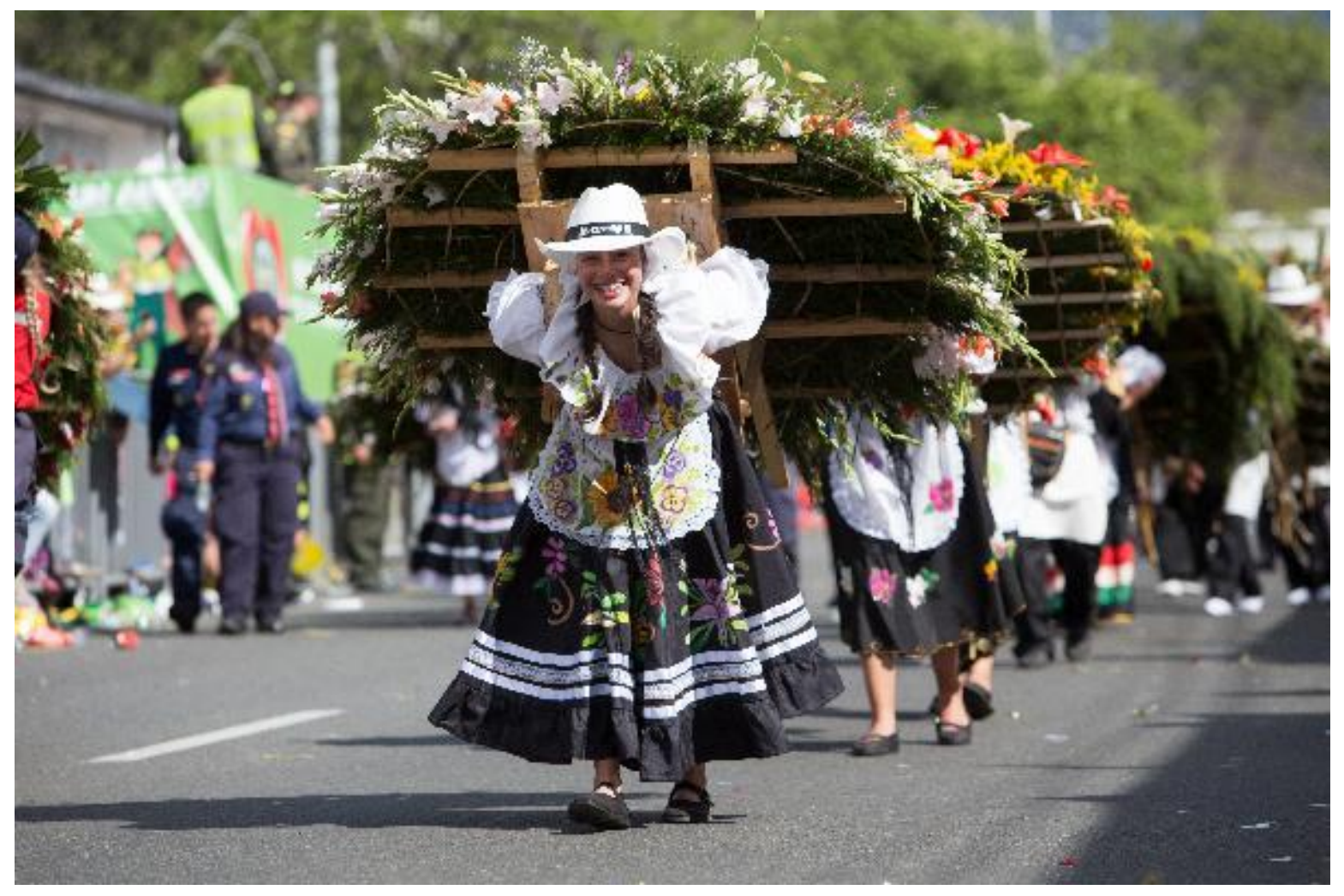

Fuente: Alcaldía de Medellín, galería Feria de las Flores (2012) 


\section{La historia de una tradición}

"Incluso en la historia recopilada, la relación entre silleteros y flores es muy reciente y de muy corta duración (1930 - 1960), sin embargo, se impone como símbolo cultural y se vende como tal sin importar su inexistencia” (López, 2013, p. 29)

Hay casi tantas versiones de la historia del desfile de silleteros como personas que la cuentan y artículos que la reproducen cada año durante su celebración. Por eso, esta investigación como un trabajo de memoria, indagará en algunas de ellas, con el fin de explorar la manera en que este evento y sus protagonistas son hoy elementos representativos y símbolos de Medellín y Antioquia. De manera que se partirá de la existencia de un par de investigaciones académicas al respecto, varios textos oficiales, las narraciones de los silleteros pioneros -que se dicen fundadores de la tradición- y los registros que deja la prensa cada año.

Casi todas las fuentes consultadas coinciden en que el primer desfile de silleteros fue en 1957 y tuvo la participación de los vendedores de flores, que varias veces a la semana bajaban desde diferentes áreas rurales de Medellín para comercializar sus productos en el mercado central o en otros espacios de la ciudad, una práctica muy común y que se había convertido en la actividad económica más importante de corregimientos como Santa Elena.

Así que más allá de "datos históricos" y "verificables" como fechas y nombres, a este trabajo le interesa indagar en las razones por las que fue creado el desfile, la manera en que se convirtió en un símbolo de la región y el uso, que tanto silleteros como clases gobernantes, han hecho del mismo como "tradición", de manera que sea posible mostrar cómo este evento y sus protagonistas aportan a la "nueva Medellín" a través de un pasado ideal, que examinado más allá de sus versiones oficiales también puede explicar de alguna manera el proceso de transformación de la capital antioqueña.

Existe entonces lo que puede llamarse una historia oficial del desfile de silleteros, que sin embargo es poco explorada académicamente y que no cuenta con muchos detalles, pero que para cada narrador tiene una idea común -que no está exenta de variaciones personales-: se trata de una tradición nacida en Santa Elena que viene desde los cargueros coloniales que llevaban personas y mercancías en sus espaldas y empezó a ser reconocida en la ciudad a partir de los vendedores de flores de dicho corregimiento. Con ellos se inició el primer desfile a finales de la década de los cincuenta, evento que llega hasta hoy con la participación de los descendientes de esos primeros silleteros e incluso con la presencia de algunos de ellos. 
Pero además de estas memorias derivadas de la versión estatal, surgen otras alternas que la complementan, contrarían y enfrentan, pues en la línea del conflicto de memorias que propone Michael Pollak y es desarrollado por Ludmila Da Silva Catela (2008) es necesario:

"Partir de una noción en plural, 'las memorias', para poder abordar los procesos ligados a sus construcciones en escenarios políticos donde se desatan las luchas sobre los sentidos del pasado". Así mismo "(con sus olvidos y silencios) puede intervenir con una fuerza inusitada y de manera conjunta tanto en la aprehensión y clasificación del mundo, como en la constitución de la personalidad, la construcción de la subjetividad, la elaboración de conocimiento, la transmisión de herencias y saberes".

\subsection{El primer desfile de silleteros}

"En el año de 1957, por iniciativa de don Arturo Uribe Arango, los silleteros que diariamente se reunían en la Placita de Flores, aceptaron exhibir sus artísticas cargas en un lugar más concurrido. Fue entonces cuando 40 silleteros decidieron aceptar la invitación y se congregaron una mañana de domingo en el Parque de Bolívar. La respuesta del emocionado público no se hizo esperar; entre aplausos y exclamaciones de admiración fue el mismo público quien solicitó que se realizará un desfile por la céntrica vía de Junín, la más popular de la ciudad en ese entonces, terminando en el teatro del mismo nombre" (Bolívar, 1991)

Esa podría decirse que es la versión oficial de cómo surgió el primer desfile de silleteros, de manera que es más o menos la misma narración que hacen cada año los protagonistas del evento a los turistas que los visitan en sus casas, a los periodistas antes o después de montar sus pesadas cargas a la espalda o a los asistentes a los certámenes internacionales en los que representan a Colombia como patrimonio nacional. $Y$ pese a que cada uno pone su toque personal, olvida algún detalle, cambia el nombre del organizador, la ruta o el número de participantes, todos coinciden en algo: uno de sus antepasados o ellos mismos (en el caso de los que se dicen fundadores) participó en ese desfile inicial, lo cual indicaría que esos 40 silleteros de la parada inicial se multiplicaron hasta llegar a 500. Esta misma historia es también la que puede leerse en las guías turísticas al hablar de la "tradición silletera" o los portales locales que promocionan la ciudad.

Así lo recuerda Carmen Emilia Atehortúa Zapata de 82 años, quien durante un evento público de celebración del día de las madres en Santa Elena aseguró como silletera "fundadora" que hace parte del desfile "desde que se empezó, yo estuve en el primerito desfile", pues además es hija y madre de silleteros y piensa continuar participando en él hasta que las fuerzas se lo permitan. El presentador no le pregunta y ella no da más detalles sobre esa génesis de la parada, pero al 
ser cuestionada en una entrevista personal, tampoco da muchos datos adicionales.

"Yo me acuerdo como que no nos pagaron en el primer desfile. Los primeros (organizadores) fue(ron) María Eugenia Gómez Sierra y después siguió don Efraín me parece. Éramos como 30 o 40 nada más. (Algunos participantes) Hijos está Abelardo y Luis, el esposo mío y yo, familiares, Martín Atehortúa, a uno que llamábamos Patica, Fernando, Agustín, Miguel, es que somos muchos, muchos. Yo ya estaba casada cuando empezó el desfile" (Entrevista personal a Atehortúa, mayo 12 de 2012):

Luz Estella Hincapié González de Sánchez, de 74 años también dice haber estado es el primer desfile de silleteros al lado de su esposo:

"El esposo mío era cultivador de flores y el vendía flores en la plaza de Guayaquil, entonces resultó un desfile, en ese tiempo eran muy poquitos y hoy ya somos 500 silleteros. Cuando empezaron no eran ni los 30, eso desfilábamos desde la avenida oriental, de los espejos que llamamos a pasar aquí a Guayaquil. Llegábamos al Sena. Ya salimos más lejos. La gente era aterrada porque veían ese desfile, tan poquitos y ver ahora en día tantos" (Entrevista personal a Hincapié, mayo 12 de 2012).

A este trabajo no le interesa juzgar ni hallar una verdad porque justo analiza la pluralidad de la memoria, pero si pretende demostrar que existe un discurso público sobre el origen del desfile de silleteros, transmitido incluso a sus participantes y herederos de la tradición, en el que lo importante es hacer parte de esa historia oficial, en la que no son necesarias las comprobaciones sino más bien acercarse a esa versión "establecida", pero que como toda narración no ha sido ajena a las adaptaciones que cada sujeto ha hecho de acuerdo a sus necesidades personales, ya sea como "fundador" o como heredero de la tradición.

Sin duda se considera más "autorizados" para dar este tipo de testimonios a los llamados fundadores, ese selecto grupo que dice haber hecho parte del primer desfile y que todavía no logra llegar a un acuerdo con un listado certero, pero está conformado por silleteros mayores, con muchos años dentro del evento y que hoy se dedican a contar no solo su experiencia sino la manera en la que inició todo, tal como lo hace Jhon Londoño:

"Yo le comentaba de un señor Darío Grajales, el que más demanda tenía de flores aquí -yo trabajaba con ese señor el jornal a 2 pesos cultivando flores-, como se dice en la biblia son muchos los llamados y pocos los escogidos, Darío Grajales hizo el contacto con el señor de la plaza para que le consiguiera algunos silleteros en Santa Elena, él hizo la promoción y solo logró conseguir 20 y con esos 20 bajó a Medellín. Darío Grajales fue fundador con la señora, él me comentó y yo le traje la inquietud a Leonel y a un hermano de nosotros que se llamaba Darío, y se 
acuerda Leonel como hacía silletas, fuimos nosotros tres y Óscar y otros compañeros que teníamos... ya después fuimos tomando conciencia de que no podíamos seguir trabajando de gratis" (Entrevista personal a Londoño, julio 7 de 2012).

Los segundos, descendientes de los "fundadores" y herederos directos de la tradición, narran ese primer desfile como parte de lo que podríamos llamar su pasado silletero colectivo, algunos insisten en los vínculos directos que tienen con esa fecha inicial, otros se apegan a su experiencia como silleteros y su nacimiento en Santa Elena para consolidar su palabra. Héctor Ruíz por ejemplo, no hizo parte de ese primer desfile como Jhon, Luz Estella o Carmen, pero recuerda lo que sus padres le contaron sobre él:

"En esa época mi mamá, mi papá bajaban con las florecitas para Medellín, llevaban sus flores y sus silletas para vender a la gente de Medellín, entonces resulta de que en esa época del 57, un señor don Efraín Botero que yo tuve el honor de conocer porque no hace muchos años que falleció, don Efraín era el administrador de la plaza de mercado, de la plaza de Cisneros, entonces como ellos llegaban allá todos, él se había vuelto muy amigo de la gente de Santa Elena. ¿Qué hizo este señor?, un día cualquiera con una señorita de Fomento y Turismo comenzaron con ese evento, ¿cuál fue el evento?, ese día sacaron como 20 silleteros, escogieron entre los silleteros o los campesinos que iban a vender las flores para que hicieron un pequeño desfile, según me contaban mis ancestros, así fue creciendo, al poco tiempo ya eran como 50 y después ya como 100 , eso lo hacían en cualquier época del año, yo me acuerdo que comentan que eso empezó como en un abril, después fue como en mayo y como en un junio, ya más adelante, las administraciones manejando quedaron en que la fiesta de las flores fueran el 7 de agosto, no tengo memoria de cuantos años, pero desde hace ya algunos años" (Entrevista a Ruíz, abril 7 de 2012).

En el caso de William Londoño, tesorero de la Corporación de Silleteros de Santa Elena, tampoco fue fundador, pero también tiene su versión de la historia:

"El primer desfile lo hicieron por la calle Carabobo, de la plaza de Cisneros a la Metropolitana, fue creado por el administrador de la plaza de Cisneros que se llamaba Efraín Botero. El primer desfile se creó por el colorido de flores que bajaba a la plaza de Cisneros, nosotros bajábamos o mis papás y hermanos mayores bajaban y en la cera de la plaza filaban todas las silletas y se veía un colorido hermoso de lo que era la flor tradicional como la siempre viva, el clavel, la estrella de belén" (Entrevista a Londoño, junio 9 de 2012)

Una narración similar hace Guillermo Londoño, quien asegura que su abuela hizo parte de la veintena que según él inició el desfile: 
"A alguien se le ocurrió en la plaza vieja de Cisneros ver llegar los silleteros todos juntos comercializando flores con este tipo de silleta, a una persona que ya no recuerdo el nombre se le ocurrió pensar en organizar un desfile, eso se ve tan bonito y tan llamativo que porque no hacemos un desfile, vamos por allá y empezaron a arrancar 20 silleteros haciendo ese desfile, para algunas personas fue llamativo e importante, para otros no lo fue, así a través del tiempo se fue volviendo interesante, llamando la atención, llamativo para la gente y se fue como institucionalizando" (Entrevista personal a Londoño, junio 9 de 2012).

Por su parte, Julio César Molina dice que él apenas era un niño, pero recuerda ir tras el desfile en sus primeras versiones, en las cuales le ayudaba a su padre, quien fue silletero durante 30 años y todavía cultiva flores:

"Mi papá, los abuelos, ellos hicieron el desfile ellos solitos, pero no les pagaban, les tocaba ir desde aquí desde Santa Elena por un desecho que se llama la Guadua a Medellín, y empezaron con 6 silleteros, se llamaban José Moisés, Ángel María Soto, Emilio Molina, como 6 o 7. Ellos mismos, ese grupito se lo inventaron. Entonces entre ellos dijeron vamos a hacer un desfile y se fue creciendo, se fue creciendo y lo patrocinaban, al principio nadie los patrocinaba. Ya es muy diferente porque ya lo patrocina la Alcaldía todo" (Entrevista a Molina, octubre 6 de 2012).

En este último testimonio es interesante ver cómo es posible encontrar un primer indicio de memorias en pugna, pues a diferencia de los anteriores, se refiere a los silleteros como personajes activos, con iniciativa para crear su propio evento, en vez de seguir las indicaciones de funcionarios gubernamentales como lo presentan los demás silleteros consultados sobre el primer desfile, así que se trata de un elemento nuevo que vale la pena mencionar y tener en cuenta a la hora de contrastar versiones, pues presenta una variación bastante significativa y que cambiaría de alguna manera la memoria oficial de la tradición con un papel más relevante para los protagonistas del desfile, que va más allá de ser creadores y herederos del arte de hacer silletas.

Pero a excepción de este último relato, los demás no tienen demasiadas contradicciones como para cambiar la historia oficial, pues si bien nombres, números o lugares se distorsionan constantemente y dan una cierta debilidad a cada versión, no son suficientes para transformar el sentido del surgimiento del desfile, una de las búsquedas principales de esta investigación: tienen como elemento común la intervención de un representante del gobierno local, sin importar nombre o entidad, y coinciden en que a este personaje le llamó la atención la belleza de las silletas que cargaban esos campesinos-vendedores de flores y pensó en que un acto público como un desfile sería llamativo para el público medellinense. 
No se habla directamente de turismo o promoción de la ciudad, pero si se piensa en que en ese momento Medellín intentaba consolidar su imagen como ciudad "primaveral" y de "flores" con eventos como exposiciones de orquídeas y juegos floridos, así como la cantidad de festividades locales promovidas por el entonces gobierno militar de Gustavo Rojas Pinilla con la creación de la Empresa Colombiana de Turismo, reforzado por su similar regional denominada Oficina de Fomento y Turismo, que fue la organizadora de dicho desfile según varios de los silleteros citados, así como el antropólogo Edgar Bolívar (2001):

"La ciudad lanzada al escenario internacional por el auge de sus industrias, revertirá sobre sí el tema de lo floral para conseguir un recurso muy rentable: el turismo. A este respecto, durante más de una década se discutirá sobre la conveniencia o no del carnaval, sobre la importancia de atraer a los extranjeros y sobre la fiesta ideal que refleje el espíritu de la antioqueñidad. De todo este conjunto de propósitos y de un ideal civilizador, surge el desfile de los silleteros" ( $p$. 27).

Pero continuando con esa exploración de memorias, existen otras versiones que también contradicen a la oficial, tal como sucede con la cita de Julio Cesar Molina sobre la iniciativa silletera de crear el evento, pero que en esta oportunidad pueden afectar mucho más ese pasado idílico de la "nueva" Medellín que presenta la oficilidad. De manera que no es conveniente que sean muy difundidas y poco puede hallarse sobre ellas, pero como memorias subterráneas también luchan por abrirse paso en la historia y logran filtrarse de alguna manera en la prensa, alguna publicación académica o en las palabras del algún silletero.

Una de ellas es la que narra Óscar Londoño, de 79 años, quien también dice haber participado en el primer desfile y ser el dueño del contrato número 5 , que hoy está en manos de su hijo Juan Guillermo. Este "fundador" cuenta un relato que diferencia de los que están acordes a la memoria oficial ya mencionados, introduce un elemento conflictivo al nacimiento del evento más emblemático de los antioqueños: los silleteros no pudieron enviar sus flores a Panamá y para evitar perder el producto, pues no existía suficiente demanda en la ciudad para venderlo, surgió la idea del desfile. Aunque tampoco da más detalles sobre la razón por la que se frenó la exportación, un punto interesante para hacer comprender mejor el contexto:

"El primer desfile de silleteros se inició en abril de 1957, fue en las horas de la mañana aproximadamente, fuimos 20 los que participamos en él [...] ese primer desfile fue convocado por Darío Grajales, cultivador de flores al por mayor de aquí de la parte de La Palma, y don Efraín Botero, en ese entonces administrador de la plaza de Guayaquil, en ese momento se presentó esa convocatoria por la sencilla razón de que a donde más se exportaba era a Panamá y esa semana no había despacho a Panamá porque se hacía por razones que habrían allá, no se sabe 
sobre qué sería y la flor que bajamos ese día no fue suficiente para que en Medellín se consumiera porque despachaban a la Costa, pero no hubo la posibilidad de que esa flor se gastara y no se vendía por eso motivo porque no se pudo exportar y porque Medellín no vendía toda esa flor, entonces eran 250-300 silleteros esperando que abrieran la plaza de mercado para comprar un tiquete que valía 1 peso[...], ahí fue cuando iniciaron ese programa, dijeron hagamos un desfile de silleteros a ver cómo es esto o cómo nos puede ir, ahí fue cuando se inició el primer desfile con 20 personas" (Entrevista personal a Londoño, julio 7 de 2012).

Esta versión coincide con la publicada por el diario Adn el 31 de julio de 2014, aunque también varía con relación a la fecha exacta, el número de participantes y el recorrido de la parada, pero se refiere a la misma protesta como la razón principal para el primer desfile, aunque es importante anotar que se refiere a "feria" como si fuera el desfile y llama la atención que no se tenga en cuenta la gran diferencia existente entre ambas, pues aunque en la actualidad pueden ser sinónimos no surgieron de la misma manera y son dos historias diferentes:

"Una protesta que se volvió tradición. Así nació la Feria, con una marcha de rechazo de los campesinos de Santa Elena por la suspensión de la exportación de flores a Panamá [...] La primera versión se realizó el 1 de mayo de 1957, y desde 1985 se tiene establecido que los primeros siete días de agosto se convierten en el escenario para la manifestación colectiva más alegre de la ciudad. Aunque mayo fue el mes asignado a las flores, a partir de 1958 la feria se pasó para agosto, mes de la independencia antioqueña [...] El cultivo de flores por su parte, fue la actividad comercial predilecta en veredas del oriente antioqueño. Las flores se exportaban a ciudades colombianas como Cali, Barranquilla, Santa Marta, Bogotá y también a Panamá. En los años 50, por una controvertida decisión gubernamental, suspendieron la entrada de las Flores de Santa Elena a Panamá.

Don Efraín Botero, el entonces administrador de la plaza de Guayaquil, propuso a los cosecheros de flores realizar una marcha para protestar por la medida. Recuerda Darío Grajales, uno de los cultivadores más prestantes de la época, que fue a quien más le sonó la idea de marchar. Reunió a sus 20 peones en el sector de Amador con Junín, en el centro de Medellín, para marchar con sus silletas tradicionales hasta el atrio de Villanueva, hoy la catedral Metropolitana.

Luego, el director de la Oficina de Turismo y Fomento, Arturo Uribe Arango, organizó un desfile con los mismo silleteros de Santa Elena, que además, tenían la costumbre traer mercancía del pueblo y flores multicolores para comercializarlas en diferentes plazas e iglesias de la ciudad.

El primer desfile salió del Parque de Bolívar, recorrió la carrera Junín y terminó con una exposición en el atrio de la Catedral Metropolita. A la cita acudieron 40 silleteros que cambiaron los víveres que transportaban en sus espaldas por flores. Luego se realizó una exposición organizada por el Club de Jardinería de Medellín y monseñor Tulio Botero" (Redacción diarioadn.co, 2014). 
Volviendo a la versión del silletero Óscar Londoño, llama la atención encontrar un nuevo testimonio de este fundador sobre los orígenes del desfile, pero en un tono diferente, mucho más cercano a la versión oficial. En el texto publicado en el diario El Colombiano el 7 de agosto de 2008 no se habla de protestas o exportaciones alegadas en la entrevista personal como marco de inicio del evento, sino más bien de la iniciativa del administrador de la plaza de mercado, tal como lo dice la narrativa oficial. Así que surge la pregunta de si se trata de una especie de "relato público" del silletero, que al tratarse de una entrevista con un medio de comunicación masivo prefiere acomodarse a las versión más aceptada; o si es una edición del periódico regional, que decide no contrariar la oficialidad y el pasado idílico de la "nueva" Medellín y omite o cambia las palabras del fundador. Sin embargo, sea cual sea la explicación a este cambio de narración, es importante resaltar la existencia de esos dos discursos, incluso en la misma persona:

“(Óscar) Recordó que una vez en abril de 1957, Efraín Botero, administrador de la plaza de Cisneros, les propuso a los vendedores de flores hacer un pequeño desfile desde la Plaza hasta el Palacio Municipal. 'Veinte personas levantamos la mano. Los demás no, porque, usted, sabe, en todos los grupos hay unos que tienen pereza; otros, desidia, y no participan" (Saldarriaga, 2008).

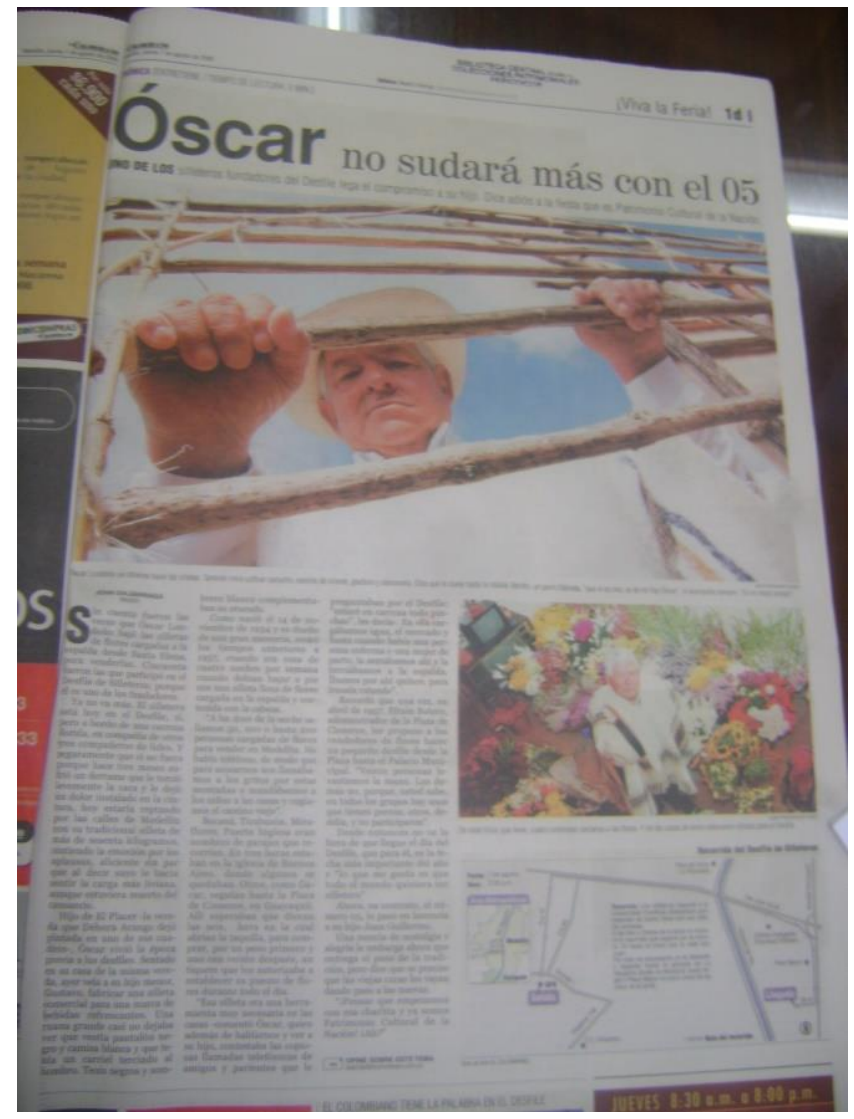

Fuente: Hemeroteca Universidad de Antioquia. Febrero 2015. 
Una tercera versión sobre el inicio del desfile de silleteros se refiere a una parada previa a la de 1957 y surgida como parte de una celebración religiosa y cívica con motivo de la inauguración de una nueva iglesia, según lo dice Germán Suárez Escudero en su libro "Medellín. Estampas y brochazos", como lo indica una publicación del periódico El Colombiano el 9 de agosto de 2014 titulado "En 1807 hubo un desfile de silletas":

"El primer desfile de silleteros realizado en Medellín no sucedió, como se cree habitualmente, a mediados del siglo pasado. Ocurrió en 1807, para una de las inauguraciones del templo de la Veracruz.

Ese primer desfile fue convocado por el señor José Peinado Ruiz, quien también manejaba el negocio del aguardiente. El templo de la Veracruz, que fue construido por segunda vez a partir del 26 de septiembre de 1791, fue terminado por etapas y cada una de ellas fue inaugurada. En 1803, en 1807 y 1809.

En la segunda, él convocó a floricultores de Santa Elena, indica Suárez Escudero, para que bajaran desde el alto gran cantidad de lirios, rosas y claveles, "que pagó a precios exagerados', y que regó en el suelo del templo" (Saldarriaga, 2014).

Es interesante continuar examinando de manera más general lo que dice la prensa sobre el tema, pues la historia del desfile es bastante recurrente en los artículos que suelen publicarse antes y después del mismo, lo cual resulta muy lógico si se tiene en cuenta que el discurso oficial se refiere a una tradición heredada por los antepasados antioqueños y que representa el pasado dorado de la región.

De manera que entre los textos analizados, hay 13 dedicados a recordar los orígenes del evento, 6 en El Tiempo y 7 en El Colombiano, lo cual corresponde al 11 y 7 por ciento respectivamente. En ellos se pueden encontrar afirmaciones como las del ex ministro de cultura Juan Luis Mejía Arango, quien asegura que el desfile inició en 1957 como un acto más de la feria (Mejía, 2008) o el de Guillermo Soto Teleche, también participante de la primera parada: "Unas señoras del Parque de Bolívar hicieron una exhibición de materas y flores y a alguna se le ocurrió pedirle al alcalde de entonces, Jorge Restrepo Uribe, que les ayudará con el desfile", a lo que agrega que los silleteros no llegaron a ser ni 20 , que hubo un conjunto de música llanera denominado Ariel Rey y sus muchachos como acompañantes y que el recorrido fue entre la Plaza Cisneros y el Estadio (Quintero Restrepo, 2010).

Además la prensa de la época también tiene sus propias versiones, diferentes a los testimonios y libros citados anteriormente: El Observador por ejemplo anuncia un "Concurso de silleteros" como parte del Festival de las Flores para el 28 de abril de 1957, en el que anuncia un mercado de flores y la participación de un centenar de cultivadores. No se tiene muy claro si este certamen se refiere o no al primer desfile de silleteros, que en fecha coincidiría, o si se trata de un antecedente del mismo poco mencionado en la historia. En ambos casos se 
trataría de un nuevo relato, que sin comprobar que contradice un poco la idea de que el evento surgió de manera natural y sin mucha preparación, aumenta el número asistentes y confirma su realización como un número más de la fiesta denominada entonces Festival de las Flores.

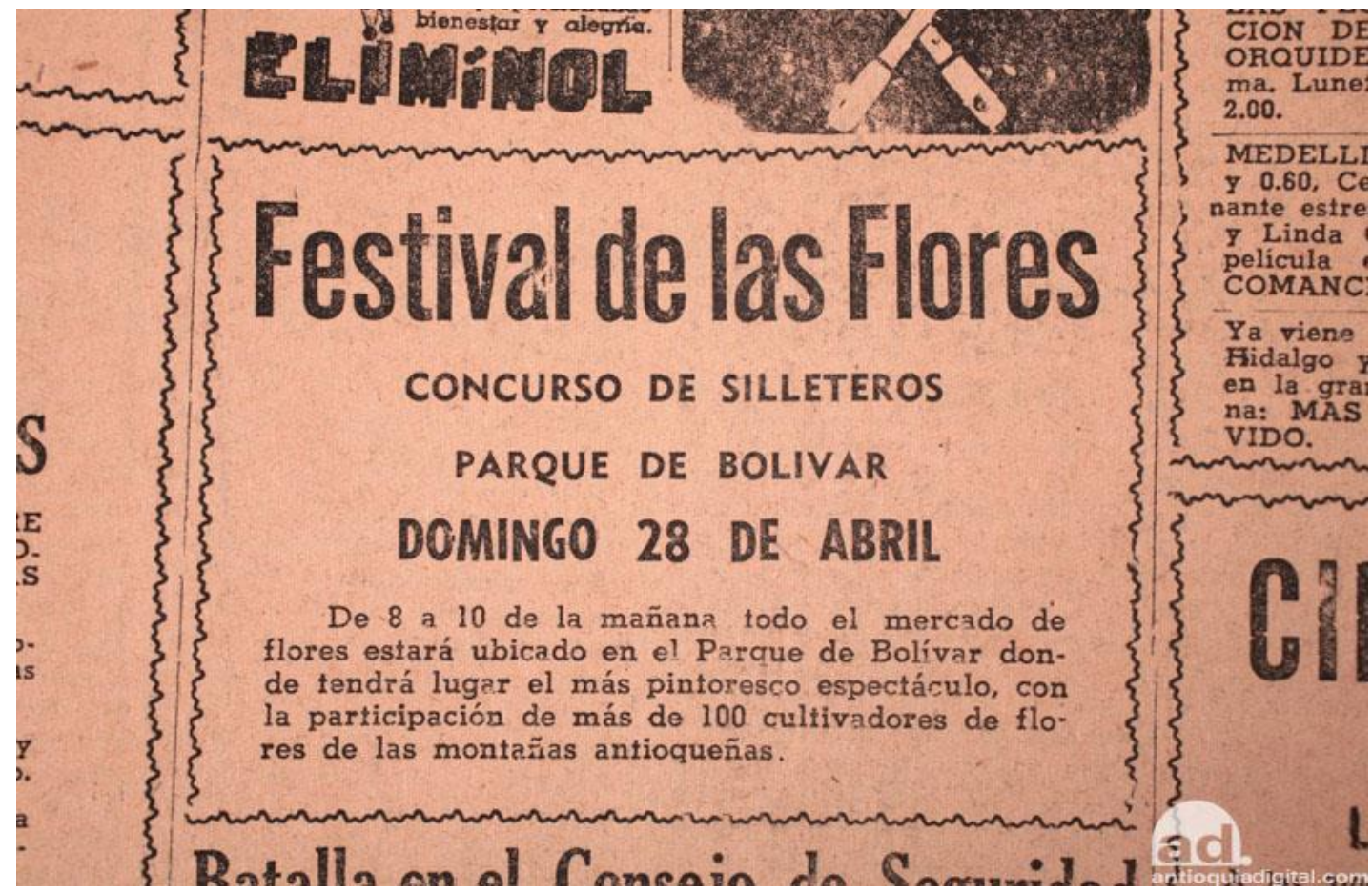

Fuente: Gobernación de Antioquia. (2007). 


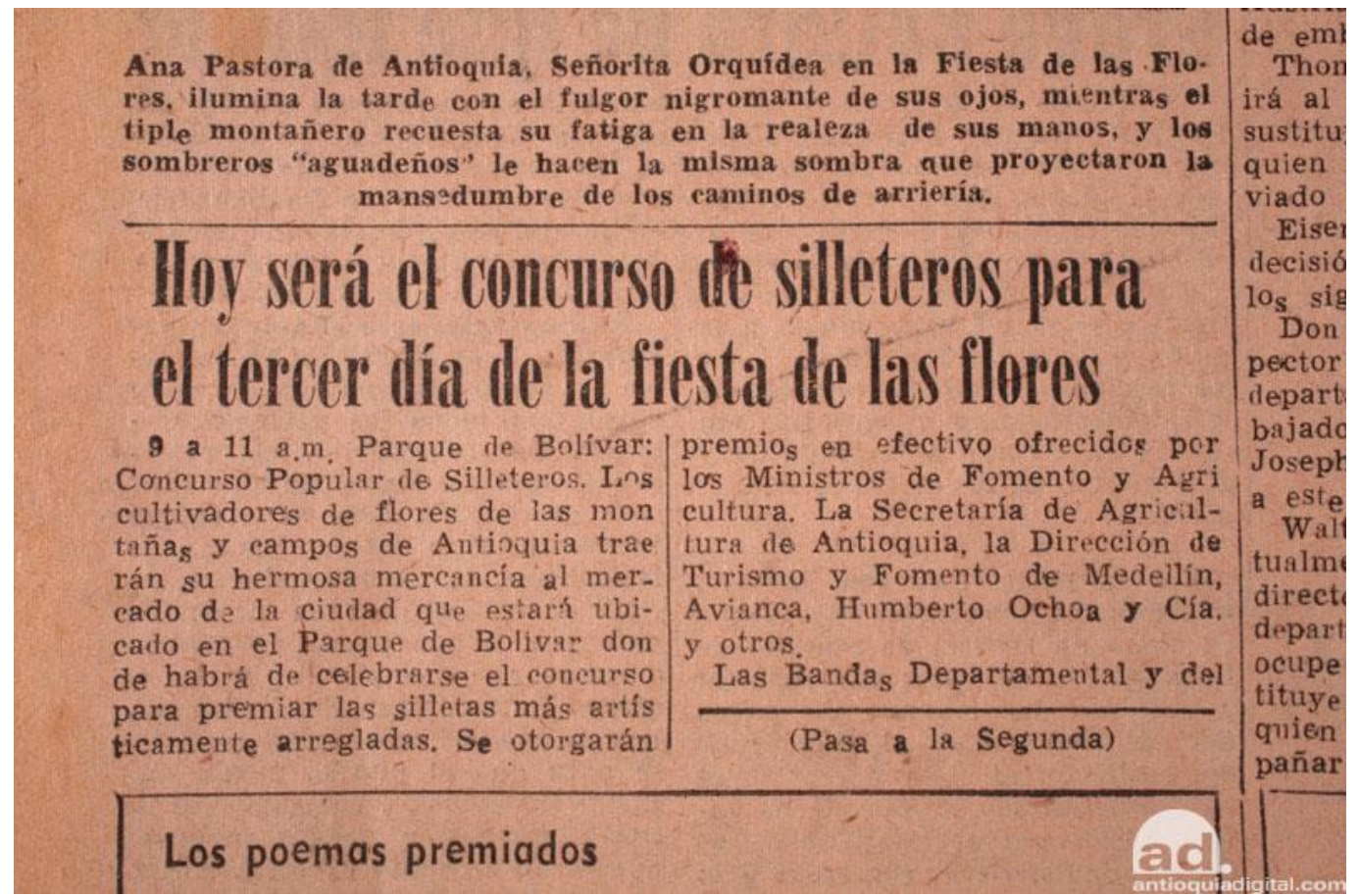

Fuente: Gobernación de Antioquia. (2007).

En El Colombiano del 2 de mayo de 1957 también puede encontrarse un artículo sobre el final de la fiesta, en la que una vez más se ratifica el surgimiento del desfile como parte de la misma y se halla una de las razones, ya expuesta en esta investigación, sobre la función del desfile como una especie de espectáculo tras el cual olvidar los problemas: "La Feria de las Flores, ha constituido un verdadero éxito. Todas las penas se han ocultado tras la fragancia y policroma belleza de los claveles y los agapantos. Todo se ha tornado en alegría y surgen las risas callejeras. El sentido bambuco y el caliente merecumbé".

Vale la pena ver cómo las versiones alternas a la oficial apelan a razones económicas y religiosas para empezar con el evento, mientras que la estatal simplemente se refiere a una idea espontánea y un poco improvisada gracias a la cual inicia una tradición, tal vez un motivo más "válido" conforme al pasado mítico e ideal que pretenden consolidar hoy con dicha celebración. Así que sí que es importante mencionar estas posibilidades y seguro las muchas otras que deben existir, pero que por límites de tiempo, espacio y acceso a las fuentes no fue posible hallar, pues dan cuenta de la falta de rigurosidad con la que se ha tratado este tema desde el ámbito académico y la riqueza memorística que existe dentro de este fenómeno, también poco explorado desde las ciencias sociales.

Tras este apartado es prudente terminar con una reflexión de tal vez el único texto encontrado en el que no se da por sentada una sola versión del génesis del desfile. En él, al igual que en este trabajo, se pretende dar cuenta de la diversidad 
de relatos alrededor y un poco la confusión dada, sobre todo con respecto a la historia oficial. Una idea con la que se espera dar pie de entrada al siguiente apartado:

"Aunque no es claro si inicialmente el desfile nace como una iniciativa institucional para el fomento del turismo en Medellín o como una expresión de reclamo de los silleteros ante sus condiciones inequitativas de intercambio comercial, si es evidente que la expresión urbana anual de mostrar y exhibir flores por medio de un Desfile con silletas llenas de flores elaboradas por los campesinos de Santa Elena, ha sido a lo largo de los años una estrategia institucional para la promoción turística de la ciudad de Medellín, a pesar de que en otros territorios y otros pueblos también se sembraban flores y surtían la ciudad con variedad de productos, en estos otros sitios no se usaban silletas, por lo tanto el espectáculo no era igual a aquellos que bajaban de Santa Elena con sus silletas llenas de frutos, flores y pobreza" (López, 2013, p. 46).

\subsection{De cargueros a silleteros}

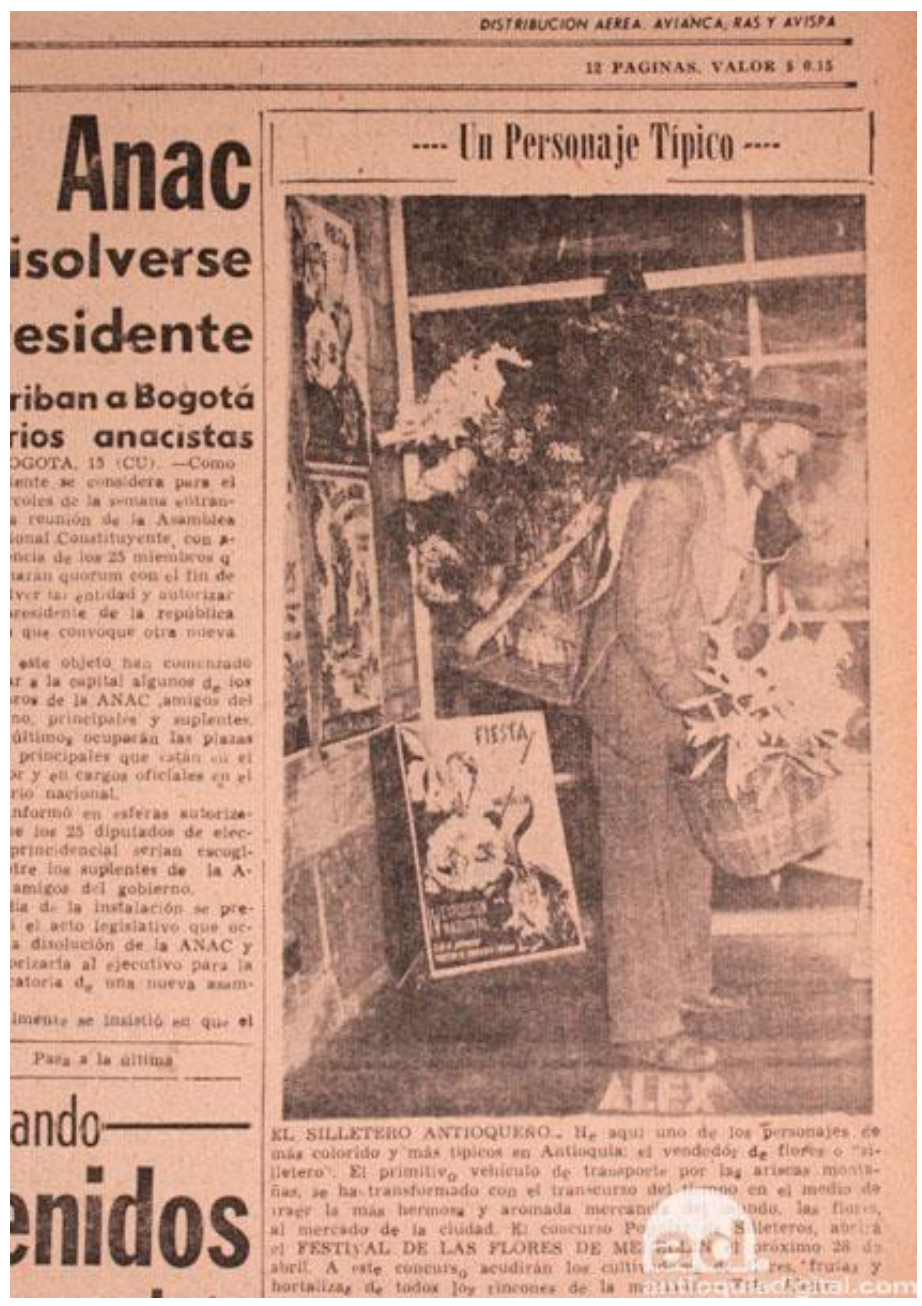

Fuente: Gobernación de Antioquia. (2007). 
Los silleteros hoy son patrimonio cultural de la nación, cada año construyen sus silletas a la vista de todos en Santa Elena y desfilan por las calles de Medellín en el evento folclórico más importante de la ciudad. Pero también son los herederos de una práctica que surgió como una actividad económica ante la necesidad de transporte por las precarias vías del entonces Virreinato de la Nueva Granada. A quienes desempeñaban esta actividad también se les llamaba "faquín", "sillero", "peón de tercio", "bestia de carga", "carguero", "estribero", "indio", "caballito" o "silletero". Y su labor era cargar mercancías o personas sobre sus espaldas en silletas, de manera que hacían largos recorridas a través de la geografía nacional para transportar sus productos o clientes hasta su destino.

Bolívar explica que se trató de una actividad muy común en el territorio que hoy se conoce como Antioquia y que si bien fue de tipo "servil, desempeñada por indígenas o descendientes directos de la población nativa", también fue "empresarial de hombres libres, blancos y mestizos, forma que arraigó principalmente en Antioquia Grande" (Bolívar, 1991, p. 7) y agrega que con el tiempo surgió la distinción entre cargueros, encargados de llevar productos y silleteros, destinados a transportar personas, aunque se trata de una división que no se ve tan clara en los escritos de la época y responde más a una interpretación del el autor.

Los viajeros del siglo XIX se sorprendieron al conocer la popularidad y necesidad de este oficio y así lo dejaron plasmado en sus crónicas, según lo dice Juan Camilo Escobar: "para 1840, según el mismo Lucio A. Restrepo, la salida de Antioquia hacia el exterior 'había que hacerla a pie, o si se trataba de alguna persona delicada en carguero'" (Escobar, 2009, p. 74).

Alexander Van Humboldt es uno de esos cronistas que describió con detalle la existencia de este oficio, que conoció durante su estancia en el actual territorio colombiano, aunque en su opinión personal la práctica debía dejarse solo para el transporte de enfermos, desamparados y mujeres, pues en su caso no fue capaz de "cabalgar sobre gente":

"Se dice montar sobre gente, como sobre caballos; andar en carguero, como andar en bestia. Entre los indios, ya antes de la conquista, era usual que personas distinguidas se dejaran cargar sobre los hombros de varios, en una especie de litera o silla portátil. El sistema actual es descubrimiento español y fruto de la comodidad, así como también de la necesidad en un país donde es imposible montar a caballo. En la provincia de Antioquia, en los dos caminos (por Mompós y Puerto del Espíritu Santo, así como por la Boca del Nare y Medellín), montar hacia la capital es casi imposible" (Humboldt, 1800, p.195)

$[\ldots]$ 
"En el pasado (Hace 20 - 30 años) era desacostumbrado y vergonzoso que hombres blancos trabajaran de silleros, es decir de cargadores de silla. Ahora se ha perdido ese prejuicio. Aquí se establece una diferencia, lo mismo que en los caballos, entre silleros que tienen un paso firme, seguro y cómodo. Algunos caminan tan incómodamente que uno se golpea terriblemente en la silla. Las sillas son muy bien ideadas, de cañas de bambú con espaldar contra el que está inclinado el asiento a $60^{\circ}$ a fin de que el transportado pueda arrimarse contra la espalda del sillero. Sin esa posición, la cargada se vuelve muy pesada. Para las piernas hay un estribo de piolas suspendido en la silla. Las personas pesadas llevan consigo sus propias sillas de madera, las que muchas veces tienen una especie de techo contra el sol. $\mathrm{Si}$, en el camino de Honda a Santa $\mathrm{Fe}$ he encontrado enfermos a los que se les cargaba a espaldas en una especie de cajón o jaula de mico, totalmente cubierta. La silla está sujeta a la espalda del sillero mediante correa de corteza cruzada, la que pasan por el hombro. Una segunda correa cruzada, descansa sobre la frente y sirve para mantener el equilibrio. El sillero camina infinitamente recto y erguido, mientras que el cargado, atrás, recostado, presenta una miserable y desamparada figura. Para subir y bajar se utilizan piedras, pedazos de roca. Si el carguero quiere liberarse totalmente de la silla, se recuesta muy extendido, con la espalda en el suelo y se desliza de ese modo de la correa de corteza cruzada" (Humboldt, 1800, p. 195).

Esta opinión del científico alemán hace pensar en la que expresó hace unos años el periodista Martín Caparrós sobre su "perplejidad" al ver cómo una práctica que claramente remite a la explotación humana se convirtió en una tradición digna de aplauso. Es un punto de vista interesante, no solo por ser diferente, venir de alguien externo a esa "cultura paisa" que tanto enaltece a los silleteros y su desfile, sino porque indaga y reprueba de alguna manera, la forma en que una actividad económica como la de los cargueros llegó a convertirse en patrimonio del país y representación de toda una región.

"Si yo quisiera — supongamos - generar conciencia sobre la miseria de los pobres latinoamericanos, intentar una caricatura sobre una forma infame de la famosa explotación del hombre por el hombre, causar fiereza y pena, nunca se me habría ocurrido, por excesiva, la imagen de un nene o una vieja doblados en dos para llevar sobre sus espaldas un objeto para el placer ajeno. Los silleteros, en su origen, eran personas de carga -en el sentido en que suele decirse bestias o animales de carga- que cargaban personas, después mercaderías, después flores; es triste, y es el tipo de costumbre que los pueblos recuerdan con vergüenza y tratan de esconder. O la muestran, si acaso, para condenarla: por memoria. Todas nuestras sociedades tienen pasados -y presentes- de explotación extrema: lo raro es que la conviertan en tradición y en espectáculo. Lo raro era que miles y miles de personas aplaudiéramos el sudor de un señor trastabillando, resoplando exhausto bajo 70 kilos de flores para que nosotros, supuestamente, la pasáramos bien. Y él también: que los doblados se enorgullezcan en representar 
su papel de doblados no era, me pareció, el menor de los logros de eso que, antaño, alguien llamaba ideología" (Caparrós, 2009).

Después de leer al argentino solo se puede pensar otra vez en cómo esta sociedad sigue dando prioridad al espectáculo y la imagen, sin importar sus consecuencias, es decir, los silleteros cargan enormes silletas para divertir y la ciudad esconde sus problemas tras carteles de transformación para entrar de nuevo en el escenario internacional.

Así que además de que no existe una razón clara sobre la elección de esta práctica silletera como representación simbólica del pasado antioqueño -como se verá a continuación-, se alude a un pasado colonial de explotación para justificar el inicio de dicha tradición y la importancia de mantenerlo. Ambas ideas contradicen mucho el pasado idílico que se pretende ajustar a la ciudad transformada que presentan los gobiernos medellinenses hoy.

Volviendo a las crónicas de viaje y la historia de los cargueros, la pregunta es ¿por qué si la actividad de los cargueros no se desarrolló exclusivamente en Antioquia se convirtió en símbolo de esta región? Para empezar se puede decir que si bien no fue la única zona en que se presentó, fue una en las que más duró debido a sus dificultades geográficas y el lento desarrollo de su infraestructura, "la supervivencia de los silleteros dependerá entonces del lento proceso de generalización de los medios mecánicos de transporte, refugiándose en aquellas comarcas y veredas hacia las cuales no era posible el ingreso de automotores" (Bolívar, 2001, p. 23).

El resto de la respuesta puede buscarse en la necesidad de hallar una identidad común a través de una actividad festiva que proyectara una imagen única de ciudad y reforzara determinadas ideologías, pues ya Medellín llevaba un tiempo con las flores como temática principal de sus eventos culturales de cara al público nacional e internacional, así que habría que reflexionar en torno a esta afirmación de Bolívar:

"En el año de 1957 es fundada la Oficina de Fomento y Turismo de Medellín, a ese año corresponde el montaje de un desfile a cargo de dicha entidad y con la intención de institucionalizarlo en lo que pretendía que fuera la semana de la antioqueñidad. La coincidencia de tal desfile con diversos acontecimientos en el ámbito político del país, merece un análisis aparte. Lo cierto es que ese resurgimiento de las celebraciones florales corresponde a uno de los muchos intentos por configurar un atractivo para los locales y los turistas" (Bolívar, 2001, p. 27).

Es que para el año de los inicios del desfile, el silletero era casi un personaje típico de la ciudad, tan presente en el paisaje urbano como décadas y centurias antes lo 
fueron los arrieros, los campesinos cafeteros o los mazamorreros. Así que puede pensarse en cómo se aprovechó dicha popularidad para elegir a los protagonistas del evento que necesitaba la ciudad para consolidar identidad, pero al mismo tiempo cómo fueron moldeándose para que no solo estuvieran acorde a esa identidad, sino que también emparentaran con la historia de esos cargueros, con los que se explica hoy su historia.

Así empezó a consolidarse ese mito utópico de los silleteros que de alguna manera retratan a la Medellín de mediados del siglo pasado y se convierten en ese pasado utópico que pretende tener la hoy "nueva" Medellín. En la prensa de la época ya pueden leerse algunos apartados que ya los describen como personajes a destacar dentro de la cultura popular, que más adelante se convirtieron en sustento de dicho mito:

"El silletero con su preciado cargamento en los hombros, se hace presente desde muy temprano en las calles de la ciudad, con sus espaldas embellecidas por los más bellos matices y regalando sus flores a la caricia enamorada de todas las miradas" (López, 1957).

"El silletero es el emblema de Medellín desde el tiempo de las abuelas, cuando se escuchaba muy de mañana por la 'beya viya' los pregones de 'flores, flores' que alternaban con las voces de la 'cajonera' anunciando la 'parva'” (Diago, 1974).

Y esa narrativa ha pasado de generación en generación, de manera que los silleteros actuales que no vivieron esas épocas o que eran muy pequeños entonces, dicen tener algunos recuerdos y han aprendido lo que sus padres $y$ abuelos relatan sobre su experiencia a inicios del siglo pasado, según explica Carlos Atehortúa, presidente de la Corporación de Silleteros de Santa Elena:

"Mis antepasados vendían flores en una silleta, pero en ese momento la silleta no se veía como un elemento como de desfile ni de esas cosas sino de transporte, en el cual era necesario, llevaban además de flores, plantas medicinales, para vender yerbabueba, tomillo, cidrón y muchas plantas medicinales que nuestros abuelos sabían para que eran, eso era efectivo porque además de silleteros eran médicos empíricos, uno les decía tengo dolor de estómago y ellos le decían coja esta ramita de yerbabuena, échela en agüita o con aguapanela y a los 15 minutos ya, no sabemos si era psicológico, físico, pero dio mucho beneficio para mucha gente de la ciudad" (Entrevista personal a Atehortúa, octubre 6 de 2012).

Jhon Londoño dice recordar claramente esos tiempos en los que surgió el desfile, entonces contaba con menos de 17 años y ya salía con sus padres y hermanos a vender flores y productos agrícolas a la ciudad:

"Nosotros bajábamos a Medellín a pie con mi mamá, con mi hermano y salíamos de aquí a las 11:00 de la noche para llegar a la plaza de Guayaquil a las 2:00 o 
3:00 de la mañana por el camino Tirabuzon a bajar a un punto que se llamaba la Aguada, de ahí bajar a Buenos Aires y de ahí a la plaza de Guayaquil, donde nos aglomerábamos a esperar que abrieran la plaza para entrar a vender las flores, o si teníamos algún compromiso a entregar a los despachadores. En ese tiempo mandábamos para Panamá, Cali, la Costa, teníamos compromisos, pero eso hace ya 55 años. Bajábamos a pie limpio. Éramos muy pobres y no teníamos para comprar zapatos, tampoco se conseguían, éramos muy guapos, de pantalones corticos". (Entrevista personal a Londoño, julio 7 de 2012).

Carlos Atheortúa también relaciona estos tiempos con sus antepasados, de quienes heredo el ser silletero:

"El primer silletero de mi familia fue mi tatarabuelo porque las silletas vienen de la parte colonial, desde el siglo XVIII, cuenta mi abuelita antes de fallecer que a ellos les tocaba bajar silletas tradicionales donde ofrecían las flores, ellos ni siquiera veían eso como un desfile sino como un medio de transporte para llevar los productos desde Santa Elena a la ciudad, además no había carreteras, bajaban por las montañas, entonces qué hacían ellos, llevaban carbón, en las silletas llevaban los enfermos, entonces era como la ambulancia del corregimiento, podemos decir que la silleta viene del siglo XVIII cuando en Santa Elena no había sino sal y oro, los indígenas que atravesaron todo lo que era la cordillera de los andes, desde Bogotá, Cundinamarca, pasaban por este territorio, se asentaban acá y acá era donde trabajaban con minas de oro y sal, eso se fue cambiando a través del tiempo por carbón y entonces ya se sacaba el carbón y se llevaba el carbón, se quemaba la leña, todas esas cositas, se llevaba a la ciudad y de la ciudad traían los productos que no había acá en la región, entonces por ejemplo la panela y otras cosas para el sostenimiento de la misma familia" (Entrevista personal a Atehortúa, octubre 6 de 2012).

Después de conocer el oficio del carguero y ver el discurso de los silleteros de hoy sobre sus antepasados más cercanos -los que siguieron recurriendo al instrumento colonial denominado silleta para conseguir su sustento diario a mediados del siglo XX, cuando Santa Elena era una de las principales proveedoras de flores para Medellín y otras regiones del país y del mundo-, puede verse un intento por unir diferentes puntos de pasado antioqueño para coincidir en uno común que refuerce la identidad y permita promover una actividad hoy considerada turística y cultural, pero que todavía no tiene muy claros sus inicios, por lo menos eso es lo que se puede concluir del recorrido hecho hasta aquí y las opiniones que ofrecen otros autores:

"Es así como con el ánimo de difundir el turismo en Medellín, se echa mano de un oficio tradicional que nació con la colonia y que se mantuvo marginal con la desaparición del mismo y la llegada de la arriería, el ferrocarril y de las vías. Se llamó la atención sobre unos personajes rurales que nadie veía antes y que se 
dedicaban a cultivos agrícolas, entre ellos las flores, en sus minifundios y a su comercialización en Medellín, a donde llegaban caminando llevando sus silletas" (López, 2013, p. 24).

Pues está claro que los silleteros que iniciaron el desfile en el 57 no son los mismos que cargaron personas y productos durante la época colonial, pero sí es posible vincularlos a través de su elemento común de trabajo (silleta), los valores de la cultura paisa ya estudiados y su procedencia campesina. Sobre todo si lo que se busca es reforzar una ideología y hallar un pasado que la sostenga, lo que ya queda claro con el famoso eslogan, del que tampoco se tienen noticias sobre cuándo empezó a usarse o quién lo creó, pero que es tan natural para cada silletero como para la mayoría de los antioqueños "Cuando pasa un silletero es Antioquia la que pasa":

"Con este slogan se condensa el sentido de la celebración: exaltación de lo regional, afirmación de valores, reforzamiento de ideales colectivos. La 'antioqueñidad' se toma las calles, escenificando con toda la parafernalia sus temas esenciales: por una parte, los silleteros establecen el contrapunto del desfile al intercalarse entre numerosos segmentos del recorrido... de otra parte sus silletas también hablan, llevan inscritos mensajes de refuerzo o, en ocasiones, proclamas y expectativas de solución a sus problemas cotidianos" (Bolívar, 2001, p. 31).

\subsection{El desfile en momentos}

Partiendo de los cargueros coloniales y llegando hasta los silleteros actuales es necesario hacer más de una parada, para comprender no solo la manera en la que llegaron a ser un símbolo de la región, sino también para sopesar su aporte a la nueva imagen de la ciudad. De una ciudad que los empezó a "ver" en el paisaje urbano justo cuando necesitó aferrarse a su idiosincrasia para lograr distinguirse en un mundo que además de hacer culto al pasado, busca originalidad a partir de sus aportes "únicos" a la sociedad en medio de su globalización.

Tras el primer desfile, ya sea en búsqueda de una atracción turística para la ciudad o como una protesta por las dificultades para exportar, lo cierto es que empieza el declive del auge de la floricultura en Santa Elena. Así como los cargueros coloniales perdieron campo de acción frente a la mejora de los caminos, la aparición de la arriería y finalmente con sistemas más modernos como el ferrocarril, los silleteros también dejaron de cultivar flores porque surgieron métodos más eficientes y productivos para sus compradores como el invernadero, que poco a poco fueron llevándose la clientela, sobre todo la internacional representada en Panamá y Estados Unidos, que compraban los productos de Santa Elena desde 1930. Para los años setenta no solo dejó de ser rentable 
cultivar y vender flores, también se popularizó el transporte público y los desfiles "naturales" de silleteros desde Santa Elena dejaron de producirse.

Así lo recuerda el diario El Tiempo el 11 de agosto de 1984 al referirse a la crisis de las flores en Santa Elena y relacionarla con la creación del desfile de silleteros:

"Desde el año cincuenta y cinco empezaron a decaer los cultivos cuando los silleteros dejaron de exportar a New York y Panamá. Dos años después, la Alcaldía de Medellín decidió organizar el primer desfile de silleteros para tratar de revivir la historia de esos hombres que todos los días durante más de medio siglo, llenaron de flores las calles, los parques, las plazas de mercado y los cementerios de la ciudad" (Hoyos, 1984).

Los silleteros de hoy no hablan mucho sobre esos tiempos, pero también coinciden en que en Santa Elena hace mucho que no se puede vivir de las flores y que ser silletero tampoco es una actividad rentable, como dice Nelson Enrique Zapata Grajales, "económicamente uno no puede vivir como silletero y menos de la flor tradicional, para vivir no vive" y agrega que "no era como primero que todas las flores nacían a la intemperie y cosechaban de todo, ahora hasta el clavel es de invernadero".

Por eso, para el silletero Juan Guillermo Londoño hoy en día no se trata de volver a esas épocas porque más que las flores lo importante en Santa Elena es la tradición:

"Uno de los puntos de la importancia de Santa Elena son las flores y las silletas como tal porque ya no es el cultivo de flores, porque los cultivos de flores ya no son de aquí. Ha habido un desplazamiento con el cultivo de flores, uno es el cultivo de flores tradicional, que son las flores de toda la vida, que la gente comercializó, produjo y vendió y fue su sustento e hizo su silleta, pero ese es un tipo de flores que no son comerciales fuertemente porque la gente no las (pide) mucho ni son de exportación. Pero ya están los famosos invernaderos en San Cristobal, Rionegro, La Ceja" [...]

"¿Por qué el cultivo de flores se ha ido moviendo tanto? Porque es un trabajo de grandes empresas, que demanda inversiones muy grandes, hay que ser un empresario grande porque eso no es para cualquiera, uno a baja escala podría producir y vender, pero el sostenimiento es costoso, la comercialización se puede volver difícil porque le toca competir con grandes empresas, usted puede producir e ir a vender ahí ventas locales, ambulantes, pero ellos manejan eso como un gran negocio, de exportación y de calidad" (Entrevista personal a Londoño, junio 9 de 2012)

Frente a esta situación los silleteros desde diferentes asociaciones vienen promoviendo desde hace varios años un proyecto de fincas silleteras mediante el 
cual se motiva a los participantes del desfile para que cultiven sus propias flores y Santa Elena vuelva a tener los jardines que la convirtieron en la "cuna" de los silleteros, en este caso con fines turísticos, pues ya que no es una actividad económica rentable por sí misma, pero que sí resulta interesante para los foráneos interesados en la cultura silletera.

Regresando a la crisis de las flores en Santa Elena, mientras todos esos campesinos que antes vivían de la venta de este producto sufrían económicamente las consecuencias, ya fuera buscando nuevas opciones laborales o reduciendo sus márgenes de ganancia frente a los precios de las grandes empresas floricultoras, el desfile de silleteros continuaba realizándose cada año, institucionalizándose, reglamentándose y consolidándose como una actividad cultural y turística de Medellín. La historia oficial no habla mucho sobre este proceso, pero las memorias de los silleteros y alguna alusión en la prensa permiten hacerse alguna idea sobre cómo sucedió.

El fundador Óscar Londoño recuerda cómo el segundo desfile fue mucho más grande y promocionado que el primero:

"En el segundo desfile con 40 (silleteros), y ahí fue cuando empezaron a colaborar con el pasaje, nos dieron 50 centavos, los que no queríamos ir en la escalera, nos veníamos caminando y lo demás lo invertíamos en bizcochos para traer para la casa. Ya se vinculó Coltejer, se formó la oficina de Fomento y Turismo, que la primera oficina fue en Palace entre Maracaibo y la avenida La Playa, por el Hotel Nutibara. Ya había que hacer fila y reclamar los fichos para poder desfilar porque ya la gente empezó a caer porque estaban dando pañoletas, azadones. Yo tenía el contrato 5 , una de las cosas que más risa me da es que había un montón de gallinas y todo eso atravesado por toda la calle y había un desorden, se hacía el desfile con la ropa normal, como uno fuera. Cuando llegaron a los 500 ya vienen aquí a Santa Elena a confirmar los contratos" (Entrevista personal a Londoño, julio 7 de 2012).

El mismo silletero cuenta que al principio la participación era libre, pero que con el aumento de participantes, así como los premios y el pago que empezaron a recibir los asistentes por sus silletas, la Alcaldía inició una serie de contratos mediante los cuales era posible hacer parte del evento como comenta William Londoño:

"Después de que se fundó el desfile de silleteros, por ahí unos cuatro o cinco años empezó lo de los contratos. Uno desfilaba sin organización y contrato, le decían a la gente que si quería ir y le pagaban la silleta sin ninguna negociación. Pero después empezó no era el contrato técnico como hoy, ya llamaban a los silleteros, aquí tiene firme un formulario o algo así. No había contrato técnico como ahora, pero si había firmas o formularios. Es muy difícil conseguir el contrato porque nadie quiere soltar los contratos. Ya ahora es con toda la técnica y el reglamento. El municipio no crea contratos son 420 más niños y junior son 500" (Entrevista personal a Londoño, junio 9 de 2012). 
Jhon Londoño quien fuera dueño del contrato número 1 recuerda cómo el gobierno local empezó a hacer estos convenios y a normalizar un poco más el evento:

\begin{abstract}
"En esa época había un director o una directora que coordinaba el desfile y ahí fue donde ya empezaron a que teníamos que ir a la oficina a que nos autorizaran un contrato para participar, y entonces ya estábamos convencidos de que nos pagaban la silleta. Usted no se imagina los silleteros cómo tomaban eso, tan a pecho, tan grande, que nos madrugábamos a las 3:00 de la mañana a hacer fila allá porque no había contratos para todos, ya había más de 100 y nos íbamos en los 'carros de la madrugada' que llamábamos para hacer fila allá... el pago era aceptable y por el desfile, que era muy agradable. Íbamos a hacer fila y se repartían 15-20 contratos y no hay más, porque es que las empresas se vinculaban con dos o tres contratos y cuando se acababan, vuelva mañana porque hay otra empresa que puede donar otros tres o cuatro, y otra vez la fila. Eso era espectacular. Pero le digo que el que había ganado la ida esa vez y volvía con un contrato que alegría. Yo tenía el contrato número 1. Ya si mañana hay repartición de contratos y usted no va no importa, se lo guardan, viene a la oficina o hasta se lo manda, pero ya no hay el problema de hacer esa fila, ya hoy en día la cuestión está muy modernizada" (Entrevista personal a Londoño, julio 7 de 2012).
\end{abstract}

Con el tiempo el desfile tomó cada vez más fuerza, se convirtió en el evento central de la Feria de las Flores, lo cual no está muy claro desde los inicios porque durante varios años dicha celebración fue suspendida y los silleteros cargaron sus creaciones en el marco de otras fiestas como la agrícola. Pero hayan iniciado o no como parte de la festividad más popular de Antioquia, en la actualidad siempre se ha considerado un acto importante por sí mismo, que de hecho para muchos da sentido a la celebración popular. Así que con los contratos vinieron normas como el vestuario, la disciplina y la prueba de alcoholemia, todos causantes de pérdida del privilegio en caso de fallar: las mujeres deben usar falda negra, delantal estampado, camisa blanca, pañoleta y alpargatas; los hombres llevan camisa blanca, pantalón negro, poncho, sombrero y carriel, la misma ropa con la que se identifica al paisa, una muestra evidente del moldeamiento de estos personajes acorde a dicha cultura.

Y con la apropiación de la parada que poco a poco hicieron los habitantes del departamento y el grado de identificación que lograron con ella, el siguiente gran paso del desfile fue su declaración como patrimonio cultural de la nación en 2003, así como su registro como marca propiedad de la Alcaldía de Medellín. Algunos autores, piensan que esto último ha traído más perjuicios que beneficios para Santa Elena y sus silleteros: Marta Peláez por ejemplo dice que "no obstante, todos estos cambios en el desfile y de la mayor valoración como patrimonio inmaterial, dada su tradición, los silleteros no han visto cambios notables que mejoren su calidad de vida (Peláez, 2012, p. 51)" y agrega una cita del periódico Soy Silletero de septiembre de 2006, "o que hayan sido objeto de un trato 
preferencial que le hagan saber que esta ley ha tenido repercusión positiva en su vida"'.

Sin embargo, varios silleteros consultados tienen una opinión diferente sobre el tema y aseguran que la declaración como patrimonio sí ha sido importante y los ha beneficiado, como el caso de Nelson Zapata:

"Cuando pasa un silletero es Colombia la que pasa, que ahora es Colombia, lo que hace que se declaró patrimonio cultural. Con eso son las fincas silleteras que han acogido mucho turista, que también es un programa de la Corporación que es para eso, para recibir turistas y atenderlos. Que vengan turistas para mi es bueno, de hecho mi casa está muy adentro de la central pero a mi casa va mucha gente y son bienvenidos, el que vaya es bienvenido a mi casa" (Entrevista personal a Zapata, octubre 6 de 2012).

De manera similar opina Carlos Atehortúa:

"Aunque no lo hemos explotado al cien por ciento como se debe, pero estamos trabajando con un proyecto que se llama el PES, plan especial de salvaguardia, estamos trabajando mancomunadamente en ese proyecto con el fin de guardar la memoria y el patrimonio de nuestra tradición silletera, la idea es no dejarlo perder, estamos trabajando muy interesadamente con los niños, con los jóvenes para que ellos sigan con ella, porque los silleteros tenemos edades de 35 años y por eso estamos involucrando a los niños, para que la cultura siga y no haya discontinuidad" (Entrevista personal a Atheortúa, octubre 6 de 2012).

Aunque también existen los que encuentran molesto cierto tipo de turismo, derivado en parte por la declaratoria patrimonial, aunque reconocen los beneficios económicos que trae para ellos y el sector como Guillermo Londoño:

"la gente ve una maravilla aquí que nosotros no vemos y vivimos aquí, pero debiéramos tener esa capacidad de valorar lo que uno tiene [...] porque el turismo se mueve mucho alrededor de esto [...] desde hace 20 años para acá el desfile, cada día, en esto si se ve la evolución, pero se ve la evolución más en otro sentido, en el fiestero, en el comercial, más que en cultural. En los días del desfile Santa Elena se llena de gente borracha, pienso que no debiera ser así, debería ser algo más cultural [...] no ven la silleta, no la conocen, estorban, roban, dan dificultades, hay gente que tiene un sentido diferente por esto y lo ve de otra manera, y lo que vienen es a bailar y a beber, entonces qué pasa con esta parte de las veredas que son más fuertes Piedra Gorda, El Placer, Barro Blanco, que son las fuertes en eso, es la concentración de la gente bailando y bebiendo, y dando lidia, lo otro es que la gente piensa también que va a encontrar 450 silletas juntas, 450 silletas están dispersas en todas las veredas y es muy difícil llegar a ellas [...] aunque hay una gran mayoría de gente con una visión diferente de esto y llegan concentrados en eso, se interesan, preguntan, lo valoran, aprenden, quieren trabajar en eso, hay 
que darles la oportunidad de que lo hagan porque ellos también se quieren llevar la flor y aquí la oportunidad se da, pero no es que se vayan a poner a hacer la silleta porque eso no es posible, las silletas se hacen en las viviendas y eso no se puede volver una montonera y un lugar tan público porque esta es nuestra casa, se imagina 50 o 100 personas aquí adentro, yo me enloquezco, yo me pongo sin saber si cuido la casa o cuido la silleta o pa donde cojo. En general el desfile se ha vuelto muy comercial, muy fiestero, muy bulloso, muy rumbero" (Entrevista personal a Londoño, junio 9 de 2012).

Y es que no es la primera vez que se habla de una "pérdida de la tradición" debido a la afluencia de público y la importancia dada al desfile y la cultura silletera, en especial tras la declaración patrimonial. Aunque no es un tema en el que se pretenda profundizar porque otros autores ya se han dedicado a ello (Peláez, 2012 y Bolívar, 2001), sí es interesante hacer algunas observaciones y disentir de algunos puntos dados por hecho en otras investigaciones como el ya mencionado, en el que se dice que no hay un aporte a los silleteros con la declaratoria, cuando varios de ellos manifiestan los efectos positivos de la patrimonialización, sin importar que lo hagan llevados por un discurso público favorecedor, tanto para la administración como para ellos.

Es válido aclarar que esa preocupación por el cambio en la tradición que lleva a la "pérdida" de la misma, explicado por el aumento de la comercialización y el auge del turismo, ya estaba presente antes de la declaratoria patrimonial. Desde el crecimiento de la fiesta y el surgimiento de la costumbre de visitar Santa Elena en la víspera del desfile para ver la fabricación de las silletas, existen diversas expresiones que apuntan en ese sentido: en los años ochenta el periódico El Tiempo publicaba un artículo en el que aseguraba que "expresión fiel de las viejas familias que habitaban el minifundio rural y luego colonizaron el occidente del país, el desfile de silleteros es el resumen de los valores de una época que liquidaron la industria y el comercio a gran escala dando lugar a una nueva sociedad" Redacción Medellín, 1984).

La investigadora Marta Peláez también hace una fuerte crítica en este sentido, pues para ella las transformaciones sufridas en el corregimiento tras la declaratoria como patrimonio y la adjudicación del evento como marca propia de la Alcaldía de Medellín, han dejado muy pocos beneficios para los silleteros:

"Los silleteros carecen de atención y apoyo para mantener sus cultivos de flores durante todo el año, pese a lo cual sienten un gran orgullo de conservar la tradición. Por su parte, la administración pública no solo manifiesta poca generosidad y poco reconocimiento a este aporte cultural y material que ofrece el campesino, sino que le impone un contrato de adhesión de prestación de servicios 
para beneficio de la imagen de la ciudad, que se publicita ampliamente, dentro y fuera del país" (Peláez, 2012, p. 52).

En medio de estas discusiones, los silleteros y su evento llegan hasta el año 2015. Y una primera conclusión es que se trata de una tradición que va más allá del origen del desfile y su intención de convertirse en un elemento distintivo de la cultura antioqueña a través de un personaje presente en varios momentos de la historia regional, con diferentes papeles y consideraciones, logrando consolidarse como un símbolo gracias a esa parada que surgió en 1957 y que lo convirtió en elemento fundamental de la identidad y el pasado del departamento. De manera que sin importar las circunstancias exactas en las que empezó puede entreverse el motivo principal de su creación.

Una última reflexión importante se hace partiendo de la corta relación entre silleteros, flores y Santa Elena que puede verse a lo largo de este capítulo -que López (2013) dice es de apenas 30 años (p. 29), lo cual tal vez puede ser de mucho más tiempo, pero que da cuenta de lo breve del vínculo-. Con lo cual se puede evidenciar una vez más el uso de una corta conexión para promocionar y vender un pasado dorado de Antioquia, que se fortalece con la declaración patrimonial en 2003, justo la época en la que empieza de la ejecución de los planes de "transformación" de Medellín. Es decir, al mismo tiempo en el que la ciudad busca imágenes positivas para destacar ante el mundo (como cuando se estableció el desfile) y borrar de alguna manera las huellas del narcotráfico, sin importar que no sean tan ciertas e históricas como la misma violencia. 


\section{Las otras ciudades}

"Medellín's problems remain severe. In 1991, a rich resident earned 21 times more than a poor one; in 2010 the multiple was 56. El Poblado, the district for the rich, feels like Singapore; Popular, the poorest neighbourhood, is reminiscent of the slums of Dhaka. But poverty in the city has fallen in recent years: $19.2 \%$ of residents now live below the official poverty line, less than the average in Colombia's metropolitan areas. The homicide rate, which peaked at 381 per 100,000 people in 1991, has dropped to fewer than 50 per 100,000"

(Redacción Américas, 2014).

En Medellín la gente sabe que cuando hay un gran evento internacional desaparecen temporalmente los indigentes en la ciudad. ¿Por qué? Porque las autoridades locales hacen una "limpieza", en especial en aquellas zonas en las que es posible que algún extranjero pueda verlos. Es un secreto a voces, pero hace parte fundamental de la logística de dichos certámenes. Efe Morales del medio independiente La Silla Vacía ${ }^{22}$ tiene su propia respuesta a propósito del Foro Urbano Mundial de Naciones Unidas realizado entre el 5 y el 11 de abril de 2014 y uno de los eventos con los que se ha demostrado la "transformación". Según él se puede contestar de manera simple: "porque la institucionalidad de Medellín se jacta de que la ciudad es un paraíso, y pues es mejor que los señores finísimos de la ONU crean que acá no hay problemas graves de desigualdad y exclusión" (Morales, 2014).

Al finalizar el evento empezaron a leerse en los periódicos del país artículos sobre la reaparición de los habitantes de la calle, tal como lo asegura El Colombiano por ejemplo "como un campo de refugiados: así se ve la avenida de Greiff en sus cruces con las calles 54 y 56, ocupada otra vez por los indigentes que fueron retirados de la avenida del Río, con motivo del Foro Urbano Mundial" (Martínez, 2014). El Espectador se refiere también a la forma en la que fueron escondidas estas personas, "de acuerdo con uno de los habitantes de la calle, ellos fueron trasladados a varios sitios a lo largo de Medellín, tras haber sido perseguidos y retenidos para no perturbar la imagen de la ciudad en el Foro Urbano mundial" y agrega el testimonio de uno de los indigentes: "Las autoridades van llegando sin previo aviso y disparando balas de caucho contra el que esté al lado [...] hacen las recogidas, los 'arrean' de un lado a otro y los hacen correr, si no corren los montan a camiones" (Redacción elespectador.com, 2014).

Citar este episodio es una manera efectiva de ejemplificar lo que sucede en Medellín, pues no se trata de un caso aislado y teniendo en cuenta el recorrido hecho a través de la metamorfosis de la ciudad y su fiesta turística principal, la idea es continuar demostrando cómo la capital antioqueña elige determinados

${ }^{22}$ Portal periodístico independiente financiado por Open Society Institute y que se enfoca en temas políticos y sociales. 
elementos para proyectarse y esconde los que no son coherentes con la imagen internacional que refleja, es decir, muestra a sus silleteros y oculta a sus indigentes, los primeros símbolo de una Antioquia campesina y trabajadora, los segundos manifestación de las diferencias sociales y la inequidad de ese mismo territorio.

Así que este capítulo pretende abordar las diferentes memorias formadas alrededor de la "nueva Medellín", que al tiempo que la contradicen, conviven en ella como muchas otras ciudades dentro de la moderna e innovadora urbe que salió del listado de las más peligrosas del mundo y sigue tratando de limpiar su imagen internacional para atraer turistas e inversión extranjera.

\subsection{Los costos de la transformación y los olvidos de la memoria}

El columnista Juan Diego Restrepo ${ }^{23}$ se pregunta en su texto semanal de la revista Semana ${ }^{24}$ del 4 de noviembre de 2014 ¿a qué costo se transformó Medellín?, de manera se refiere al precio que pagó la ciudad para ser la urbe moderna, innovadora y segura que hoy destacan los medios internacionales y de la que se sienten orgullosos sus habitantes:

"La tan promocionada transformación de Medellín en sus últimos 25 años, que hoy es un ejemplo para el mundo, según lo dicen expertos internacionales y lo replica la prensa regional hasta el exceso, no es un cuento de hadas en el que solo hay 'gente pujante' haciendo buenas obras. La realidad es que ese cambio tuvo un alto costo, pero a pocos parece importarle" (Restrepo, 2014).

El docente se refiere a una serie de acciones del gobierno local marcadas por la corrupción y la alianza con grupos delincuenciales, que según él permitieron el desarrollo de muchas de las obras de la "nueva Medellín" como el metro, el metrocable, las escaleras eléctricas de la Comuna 13 y en general la percepción de cambio de la ciudad, afirmaciones con las que empieza a crear dudas alrededor del proceso de "transformación" de la ciudad, las verdaderas razones del mismo y la realidad actual de dicha "metamorfosis".

"Bajo la imposición de un orden coercitivo, que está vigente a través de las fuerzas ilegales que gobiernan ciertos sectores de la ciudad, la ciudad es expuesta como en vitrina y sus procesos mostrados como 'únicos'. Las fuerzas de orden, tanto legal como ilegal, son protagonistas del modelo de desarrollo en la ciudad y parece que a quienes hablan de los cambios urbanos se les olvidó ese dato" (Restrepo, 2014).

${ }^{23}$ Docente de la Universidad de Antioquia, editor del portal Verdad Abierta dedicado al conflicto colombiano y autor de "Las vueltas de la Oficina de Envigado", una investigación sobre la historia del grupo criminal del mismo nombre.

${ }^{24}$ Dedicada a la actualidad, la política y reconocida por destapar escándalos como los vínculos de políticos con el paramilitarismo conocido como parapolítica. 
Restrepo (2014) explica por ejemplo cómo la construcción del metro, uno de los íconos de la ciudad y obra importante dentro de la "nueva Medellín", fue producto de una serie de acciones ilegales como el soborno para la adjudicación de las obras, al tiempo que recuerda que quien estuvo al frente de la administración de recursos y dirección de la operación fue "Diego Londoño White, miembro del llamado 'Cartel de Medellín', asesinado el 27 de noviembre de 2001, tras salir de la cárcel luego de purgar una condena de poco menos de 10 años". Esta información puede rastrearse en prensa de la época en publicaciones como El Tiempo (Nulvallue, 1995) o Semana (Redacción Nación, 1996), donde se hace referencia al retraso en la construcción del sistema de transporte masivo, su sobrecosto y la cantidad de dinero que los funcionarios locales recibieron para favorecer a la empresa que estuvo al frente del proyecto. Recientemente ha vuelto a hablarse de ese tema, debido a denuncias de fallos técnicos causados por mala administración del tren, de manera que algunos medios como el Semanario Voz han recordado algunas de las polémicas en medio de las cuales se edificó el medio de transporte:

"La deuda adquirida por el municipio y la nación es de tal manera descomunal, que debió pignorar rentas de gasolina y tabaco por el término de 83 años, siendo además la ciudadanía la que asume la mayor responsabilidad en el pago de la onerosa deuda. Además, la proyección de las obras de ingeniería suscitó polémicas por el daño ambiental, el deterioro de las zonas céntricas de la ciudad, destruyendo barrios ya construidos, con muy buena infraestructura de servicios, y despropósitos urbanísticos como la construcción de una estación del metro encima del parque de Berrío, un ícono cultural de la ciudad" (Arenales, 2015).

Volviendo a los planteamientos de Restrepo, la siguiente denuncia que hace es sobre el metrocable y sus zonas de influencia, las cuales hoy se muestran como ejemplo de transformación, pues gracias a la construcción de infraestructura para dicha obra cambió la imagen del sector y la percepción de seguridad en barrios que antes solo eran conocidos como sinónimos de violencia e inestabilidad.

"Al mirar las montañas de la comunas de la periferia en las cómodas cabinas del Metrocable no puede olvidarse que su construcción solo pudo darse cuando el proyecto paramilitar, impulsado, patrocinado y coordinado por sectores económicos pujantes de la ciudad, tolerado por la clase política y respaldado por la Fuerza Pública, logró imponer sus condiciones militares en el terreno, dejando cientos de muertos. Comunas como la 1, 2, 3 y 4, zona de influencia del primer sistema de estas características de la ciudad, y la 13, donde se construyó el segundo fueron teatro de operaciones de las Autodefensas Campesinas de Córdoba y Urabá (Accu) y, luego, de las Autodefensas Unidas de Colombia (Auc) contra todo aquello que oliera a insurgencia y bajo esa lógica murió y desapareció mucha gente inocente. Cientos de esos crímenes permanecen hoy en la impunidad" (Restrepo, 2014).

Y aunque no lo específica, esta cita hace pensar directamente en la "donbernabilidad", término con el que se denominó un supuesto "período durante el cual el capo del narcotráfico y jefe paramilitar Don Berna, de la (organización 
delictiva) Oficina de Envigado ${ }^{25}$, controló el hampa de la ciudad con un beneplácito tácito o explícito del gobierno nacional y local durante la Alcaldía de Sergio Fajardo" (La Silla Vacía, 2010). A él se refirieron reconocidos periodistas como María Jimena Duzán (2009) y Reinaldo Spitaletta (2009) y políticos, opositores al ex alcalde de Medellín como el senador Rodrigo Lara y el también ex mandatario paisa Luis Pérez Gutiérrez, quien también fue denunciado por vínculos con paramilitares.

"La administración de Fajardo terminó incursa en un pacto tácito, nunca explícito, con unas asociaciones que en realidad eran una fachada de la mafia que manejó 'Berna' desde la cárcel hasta su extradición. Por las investigaciones de la Fiscalía, se puede establecer que la esencia de ese pacto que, repito, nunca fue explícito, residía en que a cambio de que la oficina de Envigado siguiera manteniendo la capital sin muertos, las autoridades, incluso las regionales, no los perseguirían.

Las cifras confirman esta 'donbernabilidad': durante la administración Fajardo, la oficina de Envigado no sólo creció, sino que se fortaleció al conseguir neutralizar a la Policía (a través del general Pedreros) y a la Fiscalía (a través del fiscal Guillermo Valencia Cossio); tampoco se registraron mayores capturas que pudieran afectar los negocios de la mafia. Hasta cuando 'Berna' fue extraditado y mantuvo su poder intimidatorio sobre el 'Alemán' y compañía, los índices de violencia en Medellín -según la oficina del Comisionado de Paz- fueron los más bajos en su historia, en tanto que los homicidios crecían en toda Antioquia, especialmente en regiones como el Bajo Cauca" (Duzán, 2009).

Pero no solo Fajardo ha sido asociado con paramilitares, también su sucesor Alonso Salazar, quien fuera secretario de gobierno del ex alcalde, es denunciado por Pérez Gutiérrez por supuestas actuaciones de estos grupos en su campaña electoral:

"Vale recordar que, a fines de 2008, la atmósfera política se calentó con las declaraciones del ex alcalde Luis Pérez contra el actual mandatario Alonso Salazar, al que acusó de recibir apoyo de alias Don Berna durante la campaña que lo llevó a la Alcaldía. Por esas mismas fechas, analistas hablaron del 'maquillaje' de cifras desde la administración de Sergio Fajardo para camuflar el resurgimiento de la violencia urbana. Los más suspicaces decían que en el período de Fajardo lo que hubo fue un pacto de convivencia con grupos paramilitares, que comenzó a romperse.

Por aquellos días no era extraño que en determinadas comunas de la ciudad la muchachada dijera que en rigor el alcalde no era Fajardo sino Don Berna. Con la extradición de éste $-y$ tal vez desde antes - la disputa por el control de la ciudad pasó a otros bandos" (Spitaletta, 2009).

${ }^{25}$ Grupo criminal, vinculado con paramilitares y narcotráfico que hoy se considera como bacrim (bandas criminales emergentes), como llamó el ex presidente Álvaro Uribe a las organizaciones que según él surgieron de la desmovilización de las autodefensas que él promovió y que ha sido bastante cuestionada. 
Pérez también fue relacionado con las autodefensas, pues durante su gobierno ocurrió la desmovilización del Bloque Cacique Nutibara de las Autodefensas Unidas de Colombia, controlado por Don Berna (diciembre de 2003), la cual fue falsa según dijo el jefe paramilitar Freddy Rendón, alias El Alemán, en una audiencia ante el Tribunal Superior de Bogotá en marzo de 2011. El Alemán aseguró que se trató de un montaje para bajar los índices de homicidios en la ciudad y dar beneficios políticos a su jefe, que también estaba al frente de la Oficina de Envigado, banda considerada un reducto del Cartel de Medellín.

"La del Cacique Nutibara fue una desmovilización ficticia, se recogieron uniformes
y armas viejas para ese espectáculo que se montó en el Palacio de Exposiciones
por parte de las oficinas delincuenciales de Medellín, lideradas por Diego Fernando
$\begin{array}{lll}\text { Murillo", } & \text { dijo } & \text { 'El }\end{array}$

'El Alemán' señaló que hubo "una falsa desmovilización con botas nuevas, donde sectores de alto gobierno, alcalde, futuros alcaldes, participaron para bajar unos niveles de violencia y dar unos subsidios económicos a miembros de combos" (Redacción, 2014).

A acusaciones de este tipo contra tres alcaldes de la ciudad durante periodos fundamentales para la planeación, edificación y consolidación de las obras y los procesos de seguridad y convivencia que son la base de la "nueva Medellín", se suman otros puntos a los que se refiere Restrepo en su columna. Es el caso del control de la Comuna 13, donde operan las famosas escaleras eléctricas, pero también el mismo lugar en el que en 2002, durante el gobierno nacional de Álvaro Uribe y el local de Luis Pérez, se lanzaron más de 3 mil hombres del Ejército y la Policía en alianza con varios grupos paramilitares -según lo han confirmado varias sentencias judiciales- en la Operación Orión, con el pretexto de pacificar la zona y combatir la presencia de milicias guerrilleras, pues el sector era codiciado por las Autodefensas por ser uno de los pocos que no controlaba todavía. Así lo explica Maurice Lemoine en su artículo "La verdad sobre la Operación Orión" publicado por el medio independiente Las 2 Orillas en junio de 2013 sobre la importancia del control de la Comuna 13 para los paramilitares: "un corredor montañoso estratégico, une el suroeste del departamento de Antioquia y el mar, en el golfo de Urabá, una configuración muy interesante para el tráfico de armas o la exportación de cocaína" (Lemoine, 2013).

Las cifras de desaparición forzada y violaciones a los derechos humanos durante esta operación militar todavía no se concretan, pero en 2014 la Comisión Interamericana de Derechos Humanos condenó al Estado colombiano como culpable de la desaparición forzada de 45 personas, a las que hay que sumar el balance oficial, que obviamente cuenta con subregistro de casos, y que habla de 355 detenciones arbitrarias y 39 civiles heridos entre el 16 y el 20 de octubre, fecha a partir de la cual los paramilitares están al mando de la comuna.

"Diez años después sabemos un poco más sobre lo que deberíamos llamar un crimen de Estado. Los supervivientes, los familiares de las víctimas e incluso los exparamilitares han afirmado que muchos 'desaparecidos' fueron enterrados en un 
lugar llamado 'La Escombrera'. Un vertedero $50 \%$ público y $50 \%$ privado que se extiende por 15 hectáreas en la zona alta de la Comuna 13, en el límite del barrio El Salado y con el municipio San Cristóbal. 'Como Corporación Jurídica', continúa Adriana Arboleda, 'hemos registrado 92 desapariciones. Nunca hubo tantas en una zona urbana en tan poco tiempo. Pero la cifra real es mucho más espantosa'..." (Lemoine, 2013).

El mismo Don Berna, después de ser extraditado a Estados Unidos en 2008 por narcotráfico dijo que los cadáveres de 300 víctimas estaban en "La Escombrera" y que la incursión fue "planificada y coordinada conjuntamente por los paramilitares y los miembros de la IV Brigada que mandaba entonces el general Mario Montoya -nombrado después comandante en jefe del ejército colombiano por Uribe-", quien dimitió en noviembre de ese mismo año ante las denuncias sobre ejecuciones extrajudiciales hechas por el Ejército. La Comuna 13 también es una prueba de la supuesta desmovilización paramilitar que en realidad nunca se hizo, pues aunque en teoría las autodefensas presentes en el sector después de la Orión dejaron las armas en 2003, regresaron casi tan pronto terminaron los actos protocolarios en el centro de la ciudad, tal como lo señaló el Alemán:

"En 2005 los paramilitares abandonaron la Comuna 13 en sus vehículos para desmovilizarse. Unos días después volvieron en los mismos vehículos, vestidos de civiles, para seguir controlando el barrio. Toda la ciudad ha vivido el mismo fenómeno -lo mismo que numerosas regiones del país donde ya actúan, con los mismos modos operativos que en el pasado, las 'bandas criminales emergentes' (bacrim)-. En el corazón de Medellín, en las calles peatonales, centros comerciales y espacios públicos, pululan guardias uniformados de compañías privadas de seguridad: la mayoría son paramilitares 'reinsertados'” (Lemoine, 2013).

Gobiernos que pactaron con jefes paramilitares para repartirse el control de la ciudad y conseguir menos homicidios, una falsa calma, tan ficticia como la dejación de armas de los mismos grupos de autodefensas, que pese a la publicidad del gobierno nacional, siguieron dominando Medellín en ausencia del Estado, pues sus funcionarios parecían más concentrados entonces en proyectar y promocionar una nueva ciudad "libre de crimen" y recibir beneficios por favorecer ciertas empresas con la construcción de las millonarias obras públicas que respaldarían dicha metamorfosis. Esa es la lectura que hoy puede hacerse no solo de la columna del profesor Restrepo en Semana sino del manto de duda que cubre la capital antioqueña, antes y después de su transformación, un hecho que tampoco hay que desconocer, pues los cambios de la Medellín de hoy son evidentes en comparación con la de los tiempos de Pablo Escobar, pero en torno a la cual es necesario reflexionar para evitar caer en la idealización y no olvidar esas otras ciudades que han convivido y siguen existiendo al interior de la urbe innovadora que evidentemente no quiere hablar de ellas.

\subsection{El turismo no oficial también hace memoria}

Por mucho que las autoridades se empeñen en promover la cultura silletera, los paisajes verdes de las montañas antioqueñas y la "nueva" Medellín que fomenta la 
innovación y la tecnología, no es tan fácil olvidar las huellas del pasado. Y si bien se ha logrado una percepción de seguridad fundamental para impulsar este tipo de turismo, las huellas del narcotráfico y su estilo de vida se han convertido en un atractivo alterno al de las guías turísticas oficiales, tal vez porque los mismos gobiernos no se han encargado de abordar ese pasado más que para borrarlo.

Para un extranjero no es fácil ignorar la que fue la ciudad más violenta del mundo y a falta de recorridos históricos o lugares de la memoria que permitan conocer el pasado reciente de la ciudad (porque en vez de recordarlo, las autoridades se han empeñado en ocultarlo, creando un bache entre la incipiente urbe en la que los silleteros vendían sus flores, y la ciudad moderna que gana títulos internacionales como la más innovadora del mundo, saltándose toda la parte de las bombas y los sicarios), el mercado negro y los operadores turísticos de todo tipo no tardaron en ofrecer una serie de servicios que llenan dichas carencias, que van desde los famosos tour de Pablo Escobar hasta completos paquetes dentro del llamado narcoturismo.

Una investigación ${ }^{26}$ de Naciones Unidas y la Alcaldía de Medellín reconoce la existencia de altas tasas de este tipo de turismo en la ciudad y aunque no existen cifras exactas, hay revelaciones importantes sobre la frecuencia con que este fenómeno que atrae personas de todo el mundo con el ánimo de obtener droga y sexo fácil, pues "encaja muy sutilmente en la cadena delictiva heredada de la dinámica ilícita del narcotráfico, microtráfico y narcomenudeo que aún persiste en la ciudad de Medellín" (Oficina de las Naciones Unidas contra la Droga y el Delito, \& Alcaldía de Medellín, 2013, p. 29).

"A pesar de los esfuerzos que han implementado las Administraciones Municipales y el sector del turismo por superar el peso de una dinámica delictiva que motiva e inhibe la llegada de turistas a la ciudad, como lo señala la antropóloga Anne Marie Van Broek experta en turismo, cualquier intento de borrar el pasado de un territorio como estrategia de promoción turística se verá frustrado ya que es el mismo turista independientemente de sus motivaciones quien se encarga de avivar el fenómeno y es quien dentro de la búsqueda de prácticas legales o ilegales manifiesta un creciente interés por conocer el pasado de la ciudad que ha elegido como destino. En este caso es la dinámica de narcotráfico que padeció Medellín y que hoy sus estructuras han transformado hacia otras formas de criminalidad que ubican al consumidor como eslabón final de esa cadena de valor que les permite su financiamiento. En las entrevistas llevadas a cabo para este estudio se confirmó como el sexo y las drogas son motivaciones para elegir la ciudad como destino".

26 El Estudio exploratorio descriptivo de la dinámica delictiva del tráfico de estupefacientes, la trata de personas y la explotación sexual comercial asociada a viajes y turismo en el municipio de Medellín, Colombia, elaborado por la Oficina de las Naciones Unidas contra la Droga y la Alcaldía de Medellín. 
(Oficina de las Naciones Unidas contra la Droga y el Delito, \& Alcaldía de Medellín, 2013).

El informe dice que una búsqueda en internet permite encontrar blogs y ofertas destinadas a extranjeros, a los que no se puede acceder desde servidores en Colombia, pero que fuera del país permiten a sus futuros visitantes planear su visita, gracias a la enorme oferta de sustancias psicoactivas y prostitución que puede hallarse primero en la web, después en el hotel, el bar, la discoteca, el taxi e incluso en determinados espacios públicos de la ciudad.

"Turistas extranjeros de los dos perfiles mencionados describen a Medellín como la ciudad de las drogas y el sexo y hacen pública la experiencia que tuvieron en la ciudad, siendo generalizada la mención de los bajos costos y fácil acceso a sustancias psicoactivas y servicios sexuales, lo que hace evidente que en la cadena de valor de los dos mercados, la distancia entre la comercialización y el consumo es mínima y el acceso a bienes y servicios propios de estas dinámicas delictivas se da en referentes espaciales compartidos" (Oficina de las Naciones Unidas contra la Droga y el Delito, \& Alcaldía de Medellín, 2013).

Un dato interesante es que las nacionalidades que más recurren a este tipo de turismo son la estadounidense, la israelí, la italiana y la alemana, las mismas que tuvieron mayor registro por las autoridades migratorias entre 2011 y 2012, periodo que cubrió el estudio. Otro punto importante fue la red de explotación infantil y trata de personas que puede existir tras este fenómeno.

"Dentro de los servicios a los que acceden los turistas que visitan Medellín con motivación de consumo de drogas y sexo, el estudio logró documentar la existencia real de una oferta de explotación sexual comercial de niños, niñas y adolescentes, así como de servicios sexuales de adultos con características cercanas a la trata de personas con fines sexuales" (Oficina de las Naciones Unidas contra la Droga y el Delito, \& Alcaldía de Medellín, 2013, p. 37).

Vale la pena citar uno de los testimonios replicados en este trabajo, atribuido al proxeneta Carlos y que ilustra un poco la dinámica de este sector, así como la herencia del dinero fácil y las redes criminales legadas por la cultura del narcotráfico, que lejos de anularse está más vigente que nunca, tanto en este tipo de prácticas como en las actividades cotidianas del paisa de a pie.

"En Medellín el extranjero manda, las mujeres los prefieren porque pagan más, ellos saben que nosotros les conseguimos lo que sea y como sea, Medellín es la ciudad de las drogas y las putas, hace unos años pagaban hasta dos millones de pesos, ahora es difícil conseguir esos patos, pero igual pagan y las peladas les corren, si son entre 200 y 300 mil les cobro comisión del $10 \%$ y si son más de 800 mil se les va el $20 \%$ de la comisión, además muchas lo que buscan es enamorarlos para que las mantengan o las saquen del país, pero eso da una putería porque para mí es perder una entrada, pero ellos son los que mandan". (Oficina de las Naciones Unidas contra la Droga y el Delito, \& Alcaldía de Medellín, 2013, p. 26) 
Y la conclusión más importante es la pasividad e incluso la tolerancia de las autoridades locales frente a la problemática, pues se dan ejemplos para la ausencia en el control policial, con relatos como el que hace este turista estadounidense llamado Derek, "nosotros evadimos el control policivo, varias veces me pasó que estaba muy drogado y tenía en mis bolsillos o en mis manos marihuana y cocaína y los Policías me pasaban por el lado y me decían joye gringo pórtate bien!" (Oficina de las Naciones Unidas contra la Droga y el Delito, \& Alcaldía de Medellín, 2013, p. 33).

Llama la atención que en la presentación del libro, firmado por el titular de la Oficina de las Naciones Unidas contra la Drogas y el Delito en Colombia y el alcalde de Medellín, se hace hincapié en reconocer los logros y cambios de la ciudad en los últimos años. Además se destaca el hecho de que el aumento de este tipo de turistas, los que llegan a Colombia atraídos por el narcoturismo, lo han hecho gracias a la "transformación" de la ciudad, lo cual resulta un poco paradójico, ya que una verdadera metamorfosis de Medellín implicaría la inexistencia de las actividades que buscan esos visitantes.

"Es importante aclarar que los hallazgos del presente estudio no desvirtúan los esfuerzos por el fortalecimiento de la internacionalización de la ciudad, la promoción de su imagen como una ciudad innovadora, transformadora, empresarial y cultural que, como lo han registrado las autoridades competentes en materia de turismo y la empresa privada de la ciudad, son factores que han contribuido a que se incremente el número de visitantes.

Sin embargo, desde un análisis de la criminalidad, las herencias de los territorios que han padecido el impacto del narcotráfico asociado a los viajes y el turismo han generado otro tipo de motivaciones que activan una oferta local ilícita para satisfacer su demanda. Una de estas motivaciones que se ha extendido por distintos destinos alrededor del mundo es la oferta para el consumo de drogas o mal Ilamado 'Narcoturismo'" (Oficina de las Naciones Unidas contra la Droga y el Delito, \& Alcaldía de Medellín, 2013, p. 4).

Dicho informe fue presentado el 25 de octubre de 2013, justo después de que el diario británico The Independent publicara un polémico artículo, el 8 de octubre, denominado "Colombia: Las subastas de vírgenes en la ciudad natal de Pablo Escobar". Tal contenido causó protestas en las redes sociales y más de una reacción de desagrado por parte de las autoridades locales. El texto coincide con el informe sobre narcoturismo, al considerar que este tipo de actividades ha aumentado con la cantidad de visitantes extranjeros recibidos gracias a la "transformación" de Medellín, lo que resulta un tanto paradójico como ya se dijo, teniendo en cuenta que el tipo de realidad que describe parece más bien una continuación ampliada de viejas práctica en medio de una percepción diferente.

"Tras la fachada cosmopolita de Medellín, bandas callejeras de la ciudad atrapan niñas de hasta 10 años para luego venderlas al mejor postor" dice el pie de página de la foto principal del artículo escrito por el periodista James Bargent y que relata la manera en que menores habitantes de las zonas marginales de la ciudad son 
explotadas sexualmente por las pandillas de la ciudad, que las "reclutan" para vender su primera relación sexual a capos de la droga o turistas extranjeros.

"Las mejoras en la seguridad de la última década, que han ayudado a cambiar la reputación internacional de Medellín de una zona de guerra marcada por las drogas y la violencia extrema a una ciudad cosmopolita próspera, han abierto el turismo. Sin embargo, con la reputación de la ciudad por sus mujeres hermosas y las leyes laxas de Colombia sobre la prostitución -que es legal si las mujeres tienen 18 años o más y no hay intermediarios involucrados- el lado oscuro de la afluencia de visitantes extranjeros ha sido un boom en el turismo sexual.

Como la tasa de homicidios de la ciudad cayó, surgieron rápidamente redes de turismo sexual, muchas de ellas a cargo de extranjeros, que guían ilegalmente turistas a través de los burdeles de la ciudad y las zonas rojas. El propio comercio sexual de la ciudad es supervisado por las pandillas callejeras más grandes o los anillos de comercio sexual especializado" (Bargent, 2013).

independent.co.uk/news/world/americas/colombia-the-virgin-auctions-in-pablo-escobars-hol

News $>$ World $>$ Americas

\section{Colombia: The virgin auctions in Pablo Escobar's} home town

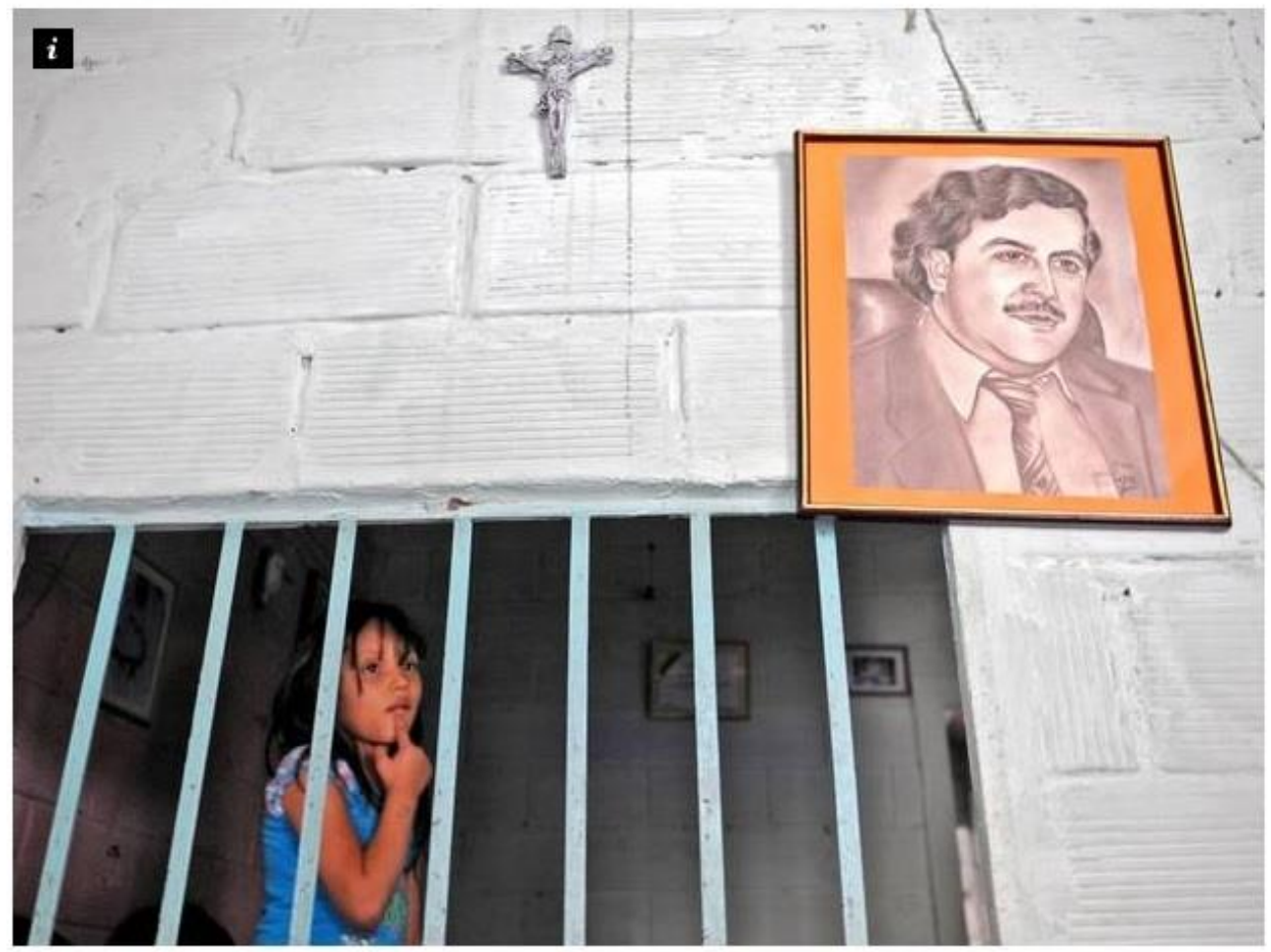

Behind Medellin's cosmopolitan façade, the town's street gangs entrap girls as young as 10 then sell them to the highest bidder

JAMES BARGENT Tuesday 08 October 2013

Fuente: Bargement, 2013. 
Las fuentes de Bargent afirman que no solo es un problema de seguridad, también se trata de un tema cultural que viene de los años del dinero fácil y la percepción de la mujer como objeto y trofeo, citando a Clara Inés Mazo, directora de la Corporación Vamos Mujer, "en el contexto de la guerra, y de la 'narcotización' de la cultura, las mujeres han pasado de ser el pensamiento de los objetos sexuales para convertirse en mercancía".

Luis Guillermo Pardo, director de la Corporación C3 (Centro de Consultoría de Conflicto) también opina al respecto:

"Cree que la situación es un claro ejemplo de la creciente brecha entre la fachada que Medellín presenta ahora al mundo, y la realidad de la pobreza y la violencia que sigue rampante en las comunas, donde la prostitución infantil y subastas vírgenes son sólo otro horror cotidiano que soportar.

'Esto se ha convertido en parte del paisaje, parte de la cruel realidad del otro Medellín -la que no es visible, la que no aparece en los medios de comunicación, que no implica grandes proyectos de construcción y restaurantes de lujo', dice Pardo. "En las comunas es la falta de oportunidades y la pobreza la que reina"' (Bargenet, 2013).

Pero además de este turismo tan específico y orientado a cierto tipo de público, existen otros planes más "livianos", que tampoco suelen agradar a los colombianos y mucho menos a sus gobernantes, pero que llaman la atención del viajero normal que quiere conocer la cultura paisa, pero también su pasado más controvertido: el de la ciudad que le dio nombre al cartel de la droga más perseguido de los años noventa. Para ellos existen opciones como el Tour de Pablo Escobar, ofrecido por operadores turísticos como Viator o Paisa Road y recomendados por portales tan reconocidos como Lonly Planet o Trip Advisor.

El polémico recorrido tiene variedad de precios y posibilidades: los más simples duran un par de horas y pueden valer unos 50 dólares, mientras que los más complejos cuentan con la opción de ser personalizados, tienen una ruta de hasta cuatro días, incluyen un encuentro con la mano derecha de Escobar, su hermano Roberto, y cuestan más de mil dólares. Contratarlos es mucho más simple que los planes de narco-turismo antes referidos, existe más de una página de internet para reservarlos y es fácil encontrar información al respecto en hostales y albergues de la ciudad. Sus principales clientes son extranjeros, de manera que no es extraño que la mayoría se ofrezcan en inglés. Varios periodistas han hecho el tour de manera clandestina, pues todos los operadores coinciden en aclarar que se necesita un permiso especial para que la prensa registre dicho plan, y gracias a ellos es posible conocer un poco más sobre él.

La periodista Salud Hernández ha sido tal vez una de las más leídas en el país por su crónica en la revista Soho y la inclusión del tema en su libro Viajes a la Colombia profunda, en la que cuenta que el tour pasó por ella y su fotógrafo en el barrio El Poblado, un sector de clase alto de la ciudad, desde donde se dirigieron a 
su primera parada en la que fuera la vivienda familiar del capo en la misma zona. Después visitaron su tumba en el sur de la ciudad y al final los condujeron hasta una "casa-museo", en la que se puede ver desde una motocicleta en la que Escobar escapó de la policía, pasando por la foto del auto en el que transportó sus primeros cargamentos hasta llegar al codiciado encuentro con el dueño del lugar, el hermano de Escobar.

"La estrella del recorrido es el encuentro con el primogénito de los ocho hermanos Escobar. 'Un amigo que estuvo ayer me dijo que es emocionante estar con un mafioso tan importante', comenta un gringo que roza la treintena y que voló de Nueva York a Medellín con otros tres amigos para celebrar en la capital antioqueña su cumpleaños.

Solo una inglesa que recorre Sudamérica y cuyo destino final es Buenos Aires, donde trabajará para una multinacional, conoce algo de los carteles, los capos y su despiadada violencia. 'Estamos en Medellín, la ciudad de Escobar, por eso quise venir. Yo solo conocía su nombre', interviene una joven australiana" (Hernández, 2012).

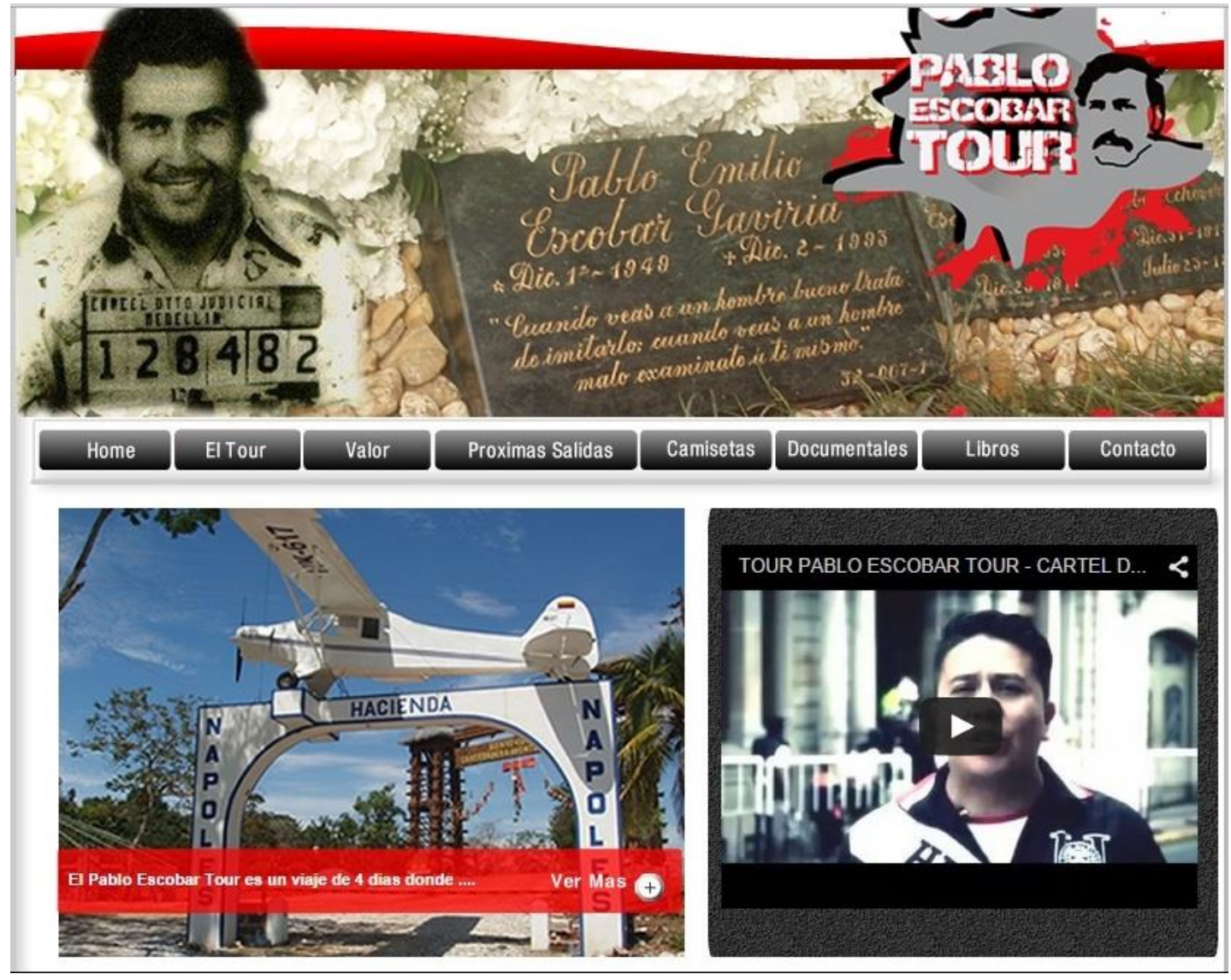

Fuente: http://www.pabloescobartour.com.co/ 
A lo largo del texto puede leerse cómo alrededor de este recorrido se consolida una memoria de ciudad, también olvidada por la oficialidad en torno al narcotraficante, que se ha convertido en todo un mito gracias a actividades como esta, a la que se suman series, películas, documentales, en las que Escobar y sus aliados figuran casi como un Robin Hood, que roba a los ricos del mundo para aliviar las carencias de los pobres de Medellín, como puede verse en el siguiente extracto, donde el guía del tour se refiere a la labor de la madre del ex jefe del cartel de Medellín:

"Como la doña era maestra, comprobó que los niños comían mal y aprendían peor. 'Fue la pionera en implantar un programa de alimentación escolar: si comen bien, aprenden mejor. Pablo le daba dinero y pagaba diez mujeres que preparaban el desayuno, un vaso de leche a media mañana y el almuerzo. Le mostró al gobierno ese camino y hoy día todos los colegios de Colombia tienen restaurantes así. Le agradecemos a la mujer que fuera la pionera'" (Hernández, 2012)

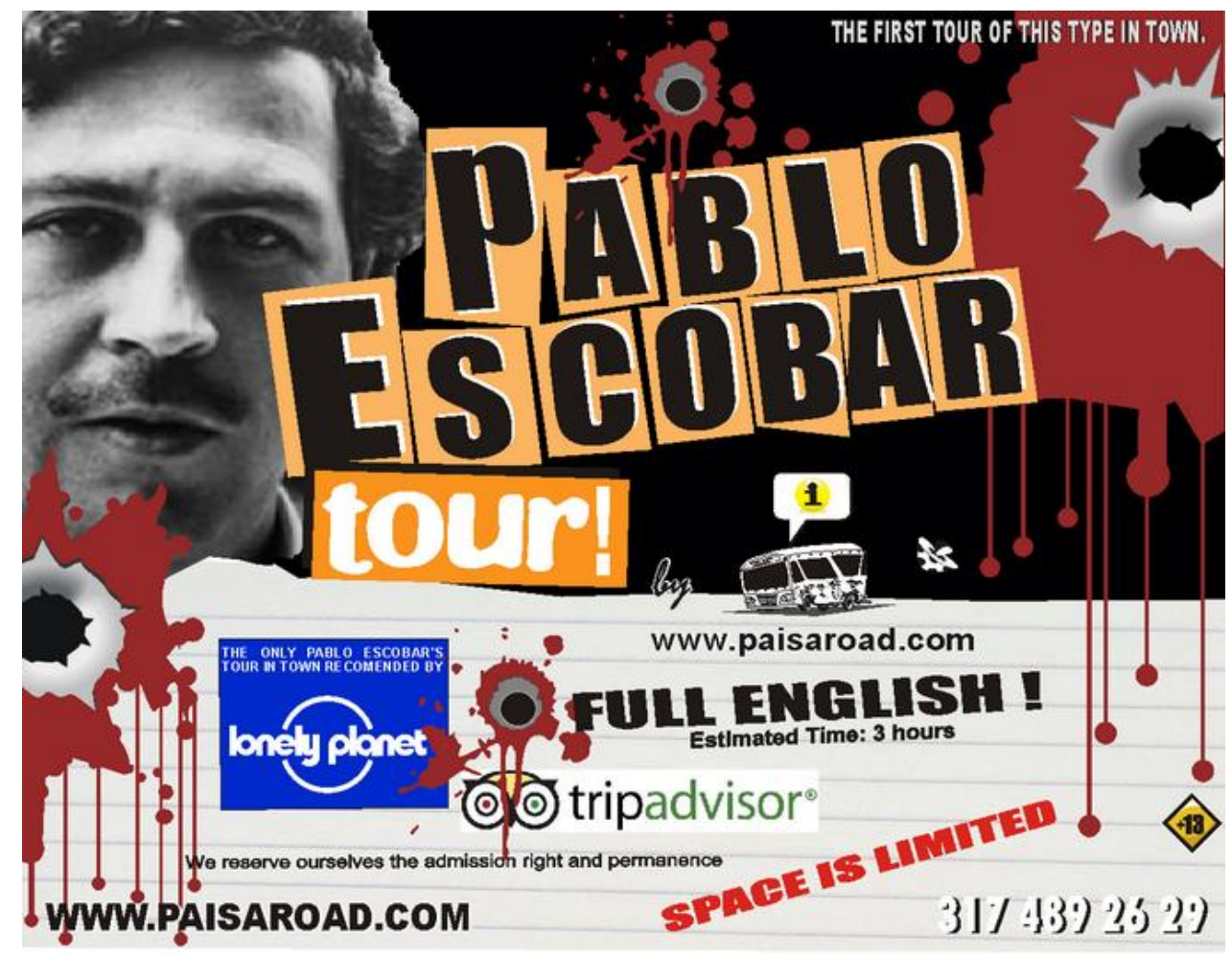

Fuente: paisaroad.com

A esto se suma la intervención que hace el hermano de Pablo Escobar ante los visitantes, ya sea para darles la bienvenida o para responder algunas de sus preguntas, en las que obviamente defiende el proceder del capo con el discurso de personaje heroico a favor de los más necesitados e incluso da una idea de los antioqueños bastante polémica:

"Cruzamos la sala, decorada sin gracia, impersonal, y en la terraza aguarda Roberto, sentado a una mesa, armado con un bolígrafo para firmar y poner la 
huella a las fotos del hermano -a 10.000 pesos el ejemplar- y a los CD. Concluida la primera tarea, posa con los turistas. Uno a uno o en parejas, todos cumplimos el ritual.

\section{$[\ldots]$}

Terminada la etapa, pasamos a la sala para la sesión de preguntas. Roberto, parado, aguarda que disparen.

¿¿Qué pensó la gente de Medellín cuando supieron que ustedes estaban en el negocio del narcotráfico?', quiere saber la joven australiana.

'En Medellín nadie decía nada porque el 90 \% de la población enviaba droga con

Pablo. Pero cuando Pablo ingresó a la política, que fue el peor error de él, la política se vino encima y ya el narcotráfico era malo, antes no porque todos recibían plata', afirma.

Otro pregunta si la imagen de amigo de los pobres no la empañó la violencia.

'Muchas de las cosas que sucedían en Colombia las hacía el gobierno y se las adjudicaban a Pablo. Igual que lo que hicieron con Hussein para poder invadir su país. Que tenía la bomba atómica y no le encontraron ni siquiera una pistola en el bolsillo cuando lo cogieron. Pero vaya a todos los barrios populares y pregunten a cualquiera qué piensa'.

Para reafirmar la querencia popular hacia el capo, Roberto rememora su entierro. 'Cuando Pablo murió, el cementerio se llenó y los carros no cabían en 4 kilómetros, unas 50.000 personas acudieron. Cuando mi madre murió, unas 10.000 personas'. (Hernández, 2012).

He aquí otra memoria de ciudad en la que es interesante detenerse, la que ofrece la industria del turismo para atraer clientes a la ciudad mediante la presentación de un pasado llamativo y controversial, que a diferencia del gobierno, sí les beneficia difundir. Es decir, la historia de ese "Robin Hood" que se valió del narcotráfico para ayudar a los más necesitados de la ciudad resulta llamativa y suma a más de uno a los tours. Sin embargo, no se pueden dejar de señalar esas otras memorias, que inmediatamente son negadas por esta versión y omitidas por la memoria oficial. Con esto se hace referencia al relato de las víctimas de Pablo Escobar, pues Colombia sigue teniendo una deuda enorme con su historia, sobre todo en lo relacionado con el periodo del narcotráfico.

$Y$ este tipo de paquetes turísticos siguen consolidando mitos como la personalidad de Escobar, que no pueden negarse y se convierten en valiosos objetos de estudio, pero que deben analizarse dentro de un contexto. Así que para esta investigación resulta interesante volver a esta imagen del capo, de alguna manera "lavada" o "acomodada", no solo para hacerla más atractiva sino para continuar su idealización, que entre otras cosas tiene vínculos estrechos con la cultura paisa, tan explorada en este trabajo, no solo por ser uno de los personajes más famosos nacidos en esta tierra, sino por las características que comparte con el estereotipo trabajado, es decir, elementos como la "creatividad" y el "emprendimiento" atribuidos tanto al paisa como al delincuente, y que desde este tipo de relatos suelen resaltarse, tal como se lee 
en las palabras de su hermano durante la visita a su casa, según la crónica de la periodista infiltrada. Así que tanto el silletero que necesita licor para continuar su jornada, como el narcotraficante "ingenioso" hace parte de ese estereotipo, que pese a su interés por resaltar solo ciertos rasgos, no puede evitar hacer parte de una caracterización más amplia y no siempre tan positiva.

Por eso, es importante no omitir estas memorias, ni las de Pablo Escobar y sus tours, ni las de sus víctimas, pues la solución no está en eliminarlas de los libros o borrarlas con photoshop de sus fotos para promocionar mejor el país y la ciudad, más bien es necesario hacerles frente recordando y evitando que memorias como las del recorrido centrado en el jefe del Cartel de Medellín, en el que se afirma que el 90 por ciento de medellinenses estaban implicados en el narcotráfico, sigan siendo las únicas que circulan y continúen consolidando estereotipos, justo contra los que se supone que lucha la "nueva Medellín".

\section{3 ¿La más innovadora, cuna de silleteros y paisas emprendedores, o el "burdel más grande del mundo"?}

El texto de The Independent citado en apartados anteriores se convirtió en un antecedente del documental hecho por Guillermo Galdos para el Canal 4 de Inglaterra denominado "Vírgenes a la venta en Colombia en 'el burdel más grande del mundo"'27, en el que también se refiere a las subastas de niñas en las comunas de Medellín y frente al que la Alcaldía de Medellín reaccionó diciendo que era un texto amarillista, falto de rigurosidad y que desconocía el contexto de la actual ciudad, según El Tiempo el 18 de septiembre ${ }^{28}$ y ante el que los indignados twitteros crearon la etiqueta \#MedellínSeRespeta para demostrar su solidaridad con la ciudad.

\footnotetext{
${ }^{27}$ http://www.channel4.com/news/colombia-medellin-prostitution-virgins-gangs-pablo-escobar

${ }^{28} \mathrm{http} / / /$ www.eltiempo.com/colombia/medellin/alcaldia-protesta-por-articulo-que-dice-que-medellin-esun-burdel/14553835
} 


\section{Virgins for sale in Colombia in 'world's biggest brothel'}

1 Tweet 655 If Recommend $4.2 \mathrm{k} \quad 8+1 \quad 39$

The barrios of Medellin are controlled by criminals and are full of prostitutes, with virgins commanding the highest prices. Guillermo Galdos meets one woman who fears for her daughter's future.

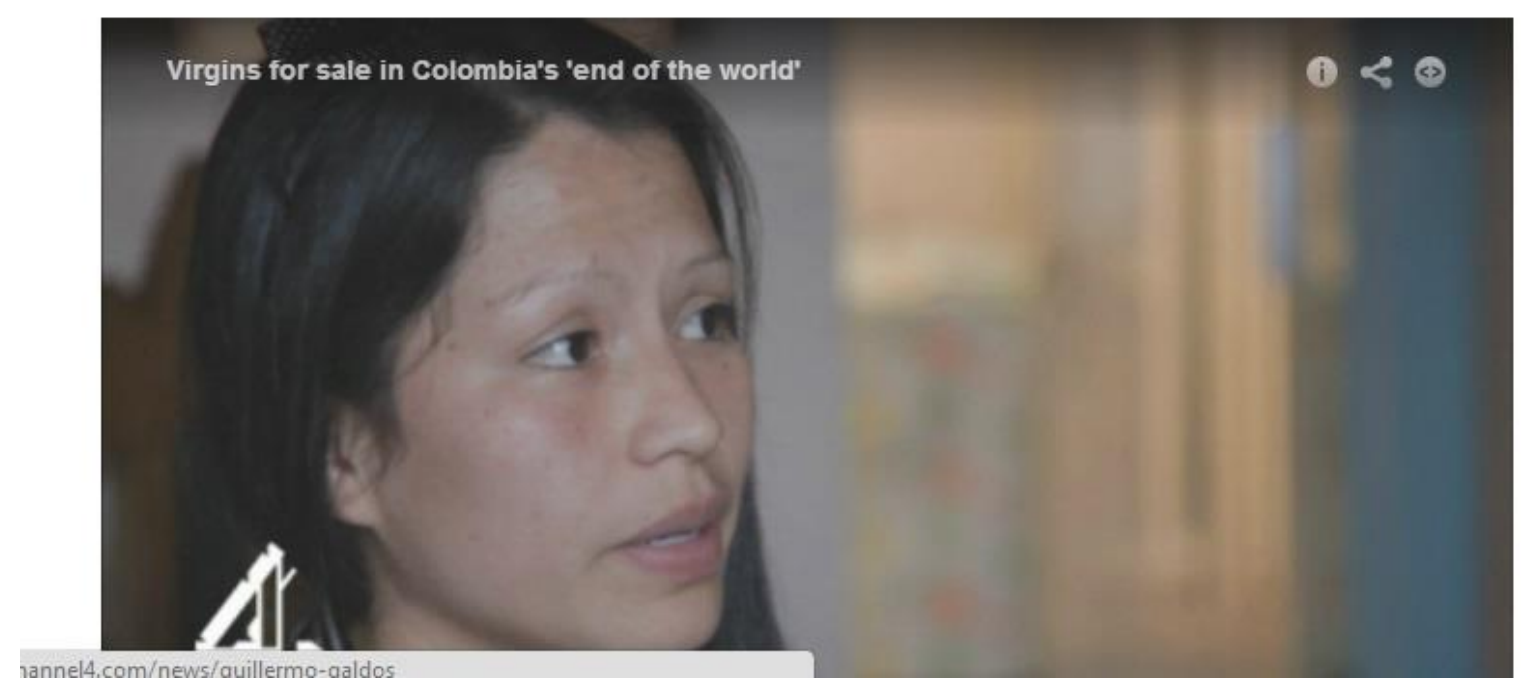

Fuente: Galdos, 2014.

De nuevo es una anécdota que ilustra la Medellín de hoy, una ciudad en la que todavía quedan muchas secuelas de su pasado violento, pero que sus autoridades no se atreven siquiera a admitir por miedo a echar a perder el maquillaje con el que desde hace unos años han logrado ocultar sus problemas. Porque tal vez la cara más amable de las otras medellines sean el narcoturismo, incluidos los tours de Pablo Escobar, pues además de ignorar la corrupción, los nexos con paramilitares de sus gobiernos o las operaciones militares que cobraron tantas víctimas civiles en el pasado reciente de la ciudad, quedan pendientes también las memorias de la urbe de hoy, que pese a su "transformación", sigue teniendo una cantidad de fenómenos relacionados con sus tiempos más oscuros, que aún en medio de sus galardones internacionales siguen vigentes y no puede seguir ocultando.

Justo cuando Medellín ganó el concurso que la declaró la más innovadora del mundo, el arzobispo de la ciudad, Ricardo Tobón Restrepo, envío un comunicado público en el que hacía 15 preguntas sobre la realidad de la ciudad, con las que claramente es posible empezar a dudar de dicho reconocimiento y la efectividad 
de las políticas implementadas para mejorar la calidad de vida de los habitantes de la capital antioqueña, una de las principales razones por las que se supone logró este título. El religioso se cuestionaba por temas que van desde el papel de los medios de comunicación frente a los problemas de la capital antioqueña hasta el narcotráfico como cultura, la ausencia de la institucionalidad en determinados sectores y la circulación de armas.

"Últimamente, se ha publicitado mucho que Medellín es la más educada, que es ciudad incluyente, que es modelo de urbe innovadora. Todo eso debe ser cierto, cuando lo repiten tanto. Nos alegramos por las cosas buenas que tiene y se hacen en Medellín. Pero, igualmente, sabemos y constatamos cada día que nuestra región es la más violenta del país, que pasan los años y no logramos aprender una convivencia pacífica, que en nuestros barrios nos estamos matando" (Redacción elcolombiano.com, 2013).

La Silla Vacía hizo el ejercicio de responder cada una de sus preguntas, contestaciones a través de las cuales evidenció cifras que, sin desvirtuar los avances de la ciudad, empiezan a demostrar la preocupante actualidad de la "nueva Medellín": en 2012 solo en la Comuna 8 los grupos delincuenciales reclutaron 440 menores de edad, según el Observatorio de Seguridad Humana de Medellín; un sicario puede cobrar entre 20 dólares y 99,4 millones por un asesinato, dependiendo de quién sea la víctima; más de 53 por ciento de los habitantes de Medellín tienen problemas de seguridad alimentaria, casi una tercera parte son pobres y hay unas 100 mil familias sin servicios públicos (Lewin, 2013).

Es que aunque en 2014 la ciudad terminó con la tasa de homicidios más baja en los últimos 35 años, el filósofo Jorge Giraldo explica que se trata de un logro "parcial y frágil":

"Son parciales porque la tasa de homicidios que tenemos está ocho puntos por encima del promedio latinoamericano y casi 20 puntos por encima del límite que fija la Organización Mundial de la Salud para calificarla como "tasa epidémica". Son logros frágiles por naturaleza, la seguridad siempre está sujeta a riesgos imprevistos y amenazas indeterminadas, pero también porque el crimen organizado y la falta de apego a las normas por parte de una franja considerable de la población siguen siendo importantes en la ciudad" (Giraldo, 2015).

Fernando Quijano, director de la Corporación para la paz y el desarrollo social (Corpades), también hizo una serie de denuncias con relación a la situación de la ciudad, en la que se refiere a diferentes fenómenos que afectan a gran parte de la población, están desatendidos por las autoridades competentes y que obviamente son poco conocidos más allá de las realidades de quienes los sufren: la desaparición forzada, la existencia de casas de tortura, el desplazamiento dentro de la misma ciudad y el control territorial por parte de bandas criminales dedicadas a la extorsión, la trata de persona y la distribución de droga, entre otras actividades delictivas. 
"¿Dónde están 320 personas que no aparecen? 177 en este año, casi 400 en el año anterior... y sume y sume...en las escombreras hay aproximadamente 300 cuerpos pero existen miles en otras partes de Medellín. En hornos crematorios clandestinos.

[...]

La desaparición forzada es una, el desmembramiento de cuerpos es otro, el desplazamiento interurbano, el año pasado nos hablaron de 9700 personas registradas que se desplazaron dentro de Medellín pero la realidad es que la mayoría no denuncia...entonces la pregunta es ¿cuántos son?

Otra realidad silenciada es el fenómeno del control territorial por parte de las llamadas bandas. Hablo de las bandas que hoy hacen parte de la Oficina del Valle del Aburrá que antes era la Oficina de Envigado, de los Urabeños que hoy son las Autodefensas Gaitanistas de Colombia y de un grupo urbano más pequeño que hoy se llaman Los Rastrojos. El 70\% del control de la ciudad está en manos de la ilegalidad..." (Orozco, 2013).

Esas son las nubes que cubren el cielo de la galardonada ciudad de los silleteros, en la que no solo hay flores y paisas pujantes, también existen un sinnúmero de problemas que no pueden ocultarse y que están en el corazón de la ciudad, así que a la Medellín innovadora y transformada hay que sumarle la Medellín del narcoturismo, la Medellín corrupta y aliada con los paramilitares, la Medellín de la versión colombiana y narco de Robin Hood, la Medellín de las mujeres voluptuosas y las niñas que venden su virginidad al mejor postor y la Medellín desigual en la que una vida puede llegar a costar apenas 20 dólares.

"Y es que Medellín son dos ciudades en una, hay una Medellín de la que se saca pecho, por reconocimientos hechos por personas como Hillary Clinton, que ni siquiera la han pisado, una ciudad que llena de orgullo a sus autoridades que con estadísticas en mano, muestran los avances en tema de seguridad, inversión e innovación, una ciudad que vista desde los vagones del metro en horas no pico, sigue siendo esa tacita de plata que alguna vez fue la envidia de un país.

Pero hay otra ciudad a la que las autoridades y medellinenses orgullosos, no quieren mirar, y que cuando miran lo único que pueden decir es que 'eso pasa en todas las ciudades del mundo'; hay una Medellín en la que transitar por la acera equivocada es sentencia de muerte, pues no se pueden cruzar las fronteras invisibles, una ciudad en la que quienes mandan son los pillos del combo, y no el señor Gaviria y las autoridades, una ciudad en la que el pan nuestro de cada día son las denuncias de robos en buses y en las calles, una ciudad en la que la mayoría de comerciantes y transportadores no deben, tienen que pagarle la vacuna a algún grupo delincuencial, so pena de ser asesinados o desplazados, una ciudad donde en el sector llamado 'El sagrado corazón', pero más conocido como 'Barrio triste' y que queda a menos de cinco minutos de la alcaldía los comerciantes de la zona, están en manos de los combos, lo cual demuestra, en manos de quien está la ciudad" (Torres, 2014). 
Aún son muchas las cifras y las realidades que hace falta abordar en este texto para tener una visión más completa de la ciudad, pero mediante la presentación de algunas de las problemáticas más difíciles que ha enfrentado y enfrenta hoy la capital antioqueña, se pretende ir más allá de la "nueva Medellín" mediante esas otras ciudades, que también existen, aunque no aparezcan en los catálogos o las guías turísticas internacionales, y no se trata de desvirtuar los logros de la "nueva Medellín" más bien es una manera de alertar sobre la necesidad de mirar de nuevo hacia atrás y narrar las diferentes memorias que surgen del mismo para poder lograr un mejor entendimiento del presente, mediante el cual se asuma la realidad sin omitir versiones, de manera que sea posible no solo verlo sino también intervenirlo. Tal vez en esta forma, la metamorfosis de Medellín esté solo en los brochures de turismo de las ferias del mundo, sino que también se viva en las calles, en las comunas, en el centro y llegue el momento en que no sea necesario "despejar" a los indigentes de las fotos con programas de diseño o del paisaje urbano con brigadas gubernamentales. 


\section{Conclusiones}

La imagen de Medellín como una ciudad nueva gracias al proceso de transformación desarrollado a partir de 2004, impulsada y mercadeada por el gobierno local, ha logrado crear una memoria oficial basada en una fracción de la realidad que destaca una urbe moderna, innovadora y emprendedora lograda gracias a un imaginario de identidad cultural que alude al pasado silletero paisa de sus habitantes (mitad del siglo XX) y todo lo que esto implica, al tiempo que parece no recordar las dos décadas de terror que vivieron sus calles por culpa del narcotráfico y el paramilitarismo.

Con el discurso de la existencia de un posconflicto, Colombia empezó en la década del año 2000 a promover su país como destino turístico y receptor atrayente para la inversión extranjera, con el fin de reactivar su economía, seriamente afectada por la guerra. De manera que con la creación de marcas país y ciudad, así como muchas otras estrategias, inició un proceso de mercadeo internacional que poco a poco recuperó la imagen positiva de la nación fuera de ella. Medellín es un claro ejemplo de esto y tal vez uno de los casos más exitosos, pasando de ser considerada la ciudad más peligrosa en 1991 a la más innovadora del mundo en 2013.

Una de las estrategias fundamentales de ese mercadeo ha sido el retorno a ciertas imágenes y símbolos culturales que han consolidado un estereotipo de los antioqueños y su forma de ser, así como de la manera en que han logrado convertir a Medellín en una ciudad industrial y a Antioquia en uno de los departamentos más prósperos del país. Por eso, los silleteros de Santa Elena como patrimonio cultural de la nación, considerados representantes de la región y protagonistas de la fiesta folclórica más importante de la ciudad, se han convertido en mensajeros fundamentales de esa nueva urbe como la cara positiva de la capital antioqueña.

¿Pero cómo llegaron estos personajes a convertirse en referentes de la región y desde cuándo es tan natural decir que "cuando pasa un silletero es Antioquia la que pasa"? tras el rastreo bibliográfico y el trabajo de campo de esta investigación se puede hablar de un periodo de tiempo corto, que empezó a instaurarse a partir del primer desfile celebrado en 1957 en unas circunstancias que todavía no cuentan con una única versión, pero que indican la existencia de una iniciativa gubernamental para reforzar la identidad de la ciudad mediante la referencia de un personaje popular y pintoresco de entonces, el silletero.

La "fundación" de esta festividad antioqueña está directamente relacionada con el concepto de invención de la tradición de Eric Hobsbawm y Terence Ranger 
(2002), pues tanto el evento como sus protagonistas infunden unos valores tradicionales, que las elites regionales buscaron consolidar de nuevo en medio de la crisis económica de Antioquia a mediados del siglo pasado. De manera que a través de la ritualización y repetición del desfile cada año, fue posible consolidar aún más esa idea de cultura paisa y renovar su fuerza en el imaginario colectivo del departamento.

Así que esa dedicación, ese amor al trabajo, esa verraquera y ese ingenio del arquetipo paisa, se vieron representados en los silleteros y su parada a partir de su instauración como tradición. Pero para lograr esa imagen fue necesario reprimir otros rasgos menos armónicos, tanto de los antioqueños como de los mismos protagonistas del desfile, pues referirse a ambos va más allá del estereotipo positivo que establecieron sus elites en el siglo XIX para sacar a la provincia de Antioquia del estado de "atraso" en el que se encontraba.

Por eso, a medida que la tradición fue cobrando importancia y se convirtió en representación de la región, fueron surgiendo medidas para lograr un prototipo de silletero más acorde a esa identidad antioqueña idealizada y positiva: es el momento en el que surgen prohibiciones como la bebida de licor durante el evento, que según testimonios de los consultados era bastante acostumbrado y hace parte de otros rasgos del paisa no aceptados y más bien escondidos por esta versión que resalta ciertos atributos positivos. Otra manera de demostrar ese moldeamiento de la imagen silletera también es el establecimiento de una indumentaria para desfilar, que funciona más o menos como un uniforme y corresponde a la vestimenta típica atribuida al paisa, tanto para mujeres como para hombres.

La relación paisa-silletero entonces se puede entrever en esa necesidad de resaltar esa "raza antioqueña" tan renombrada siglos antes en medio del afán de mejorar la situación en medio de un departamento que ya empezaba a ver frenada su boyante economía y sufrir no solo una severa crisis económica, sino el surgimiento del tráfico de drogas en su territorio y los inicios de la violencia en Colombia que desencadenó en un conflicto armado que todavía no termina.

Por eso, con el supuesto de la superación de esas difíciles épocas para la ciudad, resulta lógico apelar de nuevo a esos personajes que representan al paisa en su mejor momento, es decir, que encarnan sus elementos positivos y han eliminado ya los negativos durante ese proceso de adecuación para convertirse en símbolos, pero que siguen siendo estereotipos dentro y fuera del país: el paisa ventajoso, borracho, deshonesto y mafioso también hacen parte del imaginario de esta cultura. 
El otro nexo fundamental que le interesa a este trabajo es el de silleteros-nueva Medellín, que puede empezar señalándose en el papel de estos primeros como protagonistas de la fiesta más importante de la ciudad y el propósito de la segunda de proyectarse como una "destino de grandes eventos", es decir, los protagonistas de la Feria de las Flores son fundamentales para cumplir ese objetivo de lograr una nueva imagen internacionalmente. Solo hay que ver los videos, los comerciales e incluso las canciones que promocionan el evento, en los que tanto la alusión a lo paisa como a la metamorfosis de la ciudad son temáticas recurrentes.

Así que estos personajes y el evento que protagonizan se convierten en un caso de estudio interesante para demostrar la manera en que se insiste en promover una memoria de ciudad que fomenta una versión de la realidad que olvida su relación con el narcotráfico en el pasado y las huellas que todavía quedan de dicho vínculo. Mediante el contacto con los propios silleteros y la percepción que los medios de comunicación y los habitantes de la ciudad tienen de los mismos, es posible darse cuenta del arraigo de uno de los lemas principales de su desfile "cuando pasa un silletero es Antioquia la que pasa" y la manera en que las autoridades locales se han valido de esto para aumentar el turismo y favorecer el cambio de imagen de la ciudad.

El silletero encarna al campesino antioqueño, heredero de una "raza" única y sobresaliente en el país, como se empeñaron en "demostrar" las élites intelectuales de la región a lo largo del siglo XIX, una idea que lograron arraigar dentro y fuera del departamento a través de literatura, pintura, manuales escolares y otras manifestaciones culturales en las que se hizo referencia a la existencia de ciertas características especiales en los habitantes de esta zona del país, denominados paisas y dotados con un espíritu trabajador, aventurero, además de fortaleza, creatividad y honestidad, a los que se suman rasgos raciales identificados con lo blanco, con los cuales se justificó la ocupación de parte del sur de la entonces provincia de Antioquia durante la llamada colonización antioqueña.

Indagando en los orígenes del evento y "la tradición" lo único claro es que no existe una sola versión sobre los inicios del desfile de silleteros, así que el resultado es un ejercicio interesante que demuestra la riqueza de la memoria a través de testimonios, fragmentarias investigaciones y prensa de la segunda mitad del siglo XX. Por eso, más allá de la "verdad" alrededor del tema, lo importante es destacar la creación de un evento, basado en uno de los personajes típicos de la Medellín todavía rural de los años cincuenta, los silleteros, para formar y fortalecer una identidad folclórica propia, que distinguiera a la ciudad y la región de otras, atrajera turistas y al mismo tiempo fomentará el estereotipo de paisa, que ya desde el siglo anterior venían promoviendo sus élites. 
La festividad llega a 2015 como la más popular y una de las más queridas por los antioqueños, pues traduce el orgullo de su "raza" y rememora "una tradición" de sus antepasados. Santa Elena es conocida en todo el país por sus silleteros y sus fincas, a las que cada año en víspera del desfile llegan miles de turistas para ver de cerca las elaboración de las silletas y escuchar algunas historias de boca de sus creadores. Ante el auge del turismo y los millones que mueve el evento, los silleteros se han organizado y han creado corporaciones y empresas que negocian con el gobierno local para obtener algo del beneficio económico que esta industria cultural ingresa al país. Hoy dan charlas, organizan eventos a lo largo del año y hacen guías turísticas en sus propias casas, y aunque estas acciones han sido señaladas como "pérdida de la tradición" y exceso de mercantilización, a través de esta tesis se puede decir que más allá del decline de una costumbre, se trata más bien de la resignificación y reinvención de una tradición inventada, lo que de por sí se refiere a una situación más compleja, que va más allá del simple declive de una costumbre y se cuestiona por su mismo origen.

Se trata de una resignificación que se da en dos sentidos principales: por un lado, por parte de las élites que han usado dicha tradición de manera política y comercial para lograr determinados objetivos de carácter económico y social; y por otro, por lo mismos silleteros, que hoy pretenden aprovechar las ventajas del turismo y la representatividad de sus costumbres para obtener beneficios, no solo en el ámbito financiero sino también en el espacio público a través de la búsqueda de un reconocimiento especial como personajes emblemáticos de la cultura paisa.

Hoy la prensa internacional y los sitios turísticos de Medellín destacan a los silleteros como uno de los elementos fundamentales de la identidad antioqueña y a su desfile como la fiesta más importante de la ciudad. Así se vende la "nueva Medellín" como la cuna de los silleteros de Santa Elena, una ciudad moderna que sin embargo no olvida sus raíces y sigue teniendo los valores de sus antepasados laboriosos, ingeniosos y emprendedores, rasgos esenciales para lograr superar las épocas difíciles de Pablo Escobar y renacer de las cenizas como un ejemplo latinoamericano.

Y si bien no se pueden negar los cambios que ha logrado esta urbe porque es evidente que la situación de la ciudad en materia de seguridad y convivencia ha cambiado considerablemente tras la desarticulación del cartel de Medellín, no es posible lograr una metamorfosis como la que intentan vender los gobiernos paisas sin abordar de manera adecuada el pasado traumático de la ciudad. Y esa es una de las conclusiones más importante de esta tesis, que pese a todo el trabajo gubernamental y ciudadano en pro de la recuperación de la ciudad todavía no existe una reivindicación y una respuesta adecuada a las víctimas del narcotráfico y la violencia paramilitar en la ciudad, y mucho menos una memoria que afronte 
esta parte de la historia paisa, necesaria en toda sociedad tras procesos represivos, genocidas o violentos.

Además es importante mirar más allá de la promoción positiva de la ciudad, sin necesidad de caer en la estigmatización o los estereotipos, y entender que no es posible deshacerse de la violencia de los ochenta y los noventa borrándola de la historia porque ella no murió con Escobar. Por eso, los extranjeros todavía llegan a Medellín buscando su historia y las secuelas que dejó, esperan que se les cuente su historia, quieren conocer a sus herederos y consumir su droga. Así que si la ciudad no ofrece planes alternos, no elabora su historia y ofrece a sus habitantes una versión contrastada de esa época, su hermano seguirá diciendo a las miles de personas que pagan por un tour dedicado al famoso capo, que la gente en Medellín no decía nada sobre el tráfico de estupefacientes porque el 90 por ciento de ellos participaban del mismo, lo cual constituye un insulto a sus víctimas mediante una versión acomodada a los intereses de un criminal manipulador, que todavía se sigue venerando en las comunas de la ciudad. Porque seguro esos turistas verán los silleteros y las demás atracciones turísticas de la ciudad, pero mientras no se ofrezcan iniciativas de memoria válidas que no solo dignifiquen a las víctimas sino que ayuden a elaborar ese pasado conflictivo de la ciudad, este tipo de recorridos seguirán operando, incluso legalmente en Medellín.

Además es necesario dejar de escudarse en premios internacionales o concursos ganados y reconocer el avance, pero también enfocarse en la problemática de violencia que todavía enfrenta Medellín y que aunque logre estar alejada de los sitios turísticos y los barrios de clase alta, sigue estando presente en la periferia en forma de extorsión, represión, pobreza, desigualdad y tráfico de personas, por solo mencionar algunos de los delitos de los que muchos todavía siguen siendo víctimas en la ciudad que se dice la más innovadora del mundo.

Nota: en la etapa final de esta investigación, el 25 de abril de 2015, se presentó el Museo Casa de la Memoria en el que se hace un recorrido por los 50 años de conflicto en el país, un esfuerzo interesante, que celebro y que puede ser un buen inicio para reivindicar a las víctimas en la ciudad y ofrecer esas diferentes memorias a las que se apeló en esta investigación. 


\section{Agradecimientos}

Siempre empezaré dando gracias a mi madre, sencillamente porque nunca me cortó las alas: me apoyó completamente desde que compré ese pasaje a Buenos Aires en 2010, hasta que volví a casa, después de muchos ires y venires, para concentrarme completamente en este trabajo en 2015. Sin ella no habría logrado cumplir ninguno de esos proyectos al parecer tan ambiciosos, pero que han hecho mi vida tan plena.

Por supuesto a mi director Enrique Garguin, sin quien no hubiese podido llegar a este punto: gracias a su disposición y excelente guía pude salir de los atolladeros, aclarar ideas y mejorar cada página.

A mis hermanos Diana y Jamer, porque han sido un apoyo fundamental para cada uno de mis proyectos: ya sea para tomar fotos a periódicos, sacar libros de la biblioteca o comprar un pasaje de avión, sé que siempre puedo contar con ellos.

A Juan Pablo y Laura, que no nacían todavía cuando su tía empezó esta investigación, pero que se han convertido en uno de sus principales motivos: porque quiero que crezcan en un país en paz, pero que no olviden a quienes no pudieron hacerlo.

A Carlos, que empezó este camino conmigo y que en su recorrido, escuchó mis ideas y dudas, aún antes de perderse y caminar conmigo por los bellos parajes de Santa Elena, aún antes de sentir cómo se nos erizaba la piel al ver pasar a esos silleteros durante su evento más importante.

A David por sus hojitas de colores con las que tracé la primera ruta, por seguir estando ahí a pesar del tiempo y la distancia (hakuna matata!).

A Anthony por visitar ferias internacionales por mí, por buscar páginas de internet prohibidas, por escucharme y darme nuevas ideas, por motivarme a concluir esta etapa y empezar una nueva: por escucharme repetir una y otra vez las mismas ideas, por ser capaz de adentrarse en mi cultura sin conocerla, por motivarme a conocer otras perspectivas, por llegar a mi vida y cambiarla para siempre. Porque al encontrarlo hallé a mi compañero incondicional, a mi cómplice de aventuras, a mi motivo para sonreír todas las mañanas, a mi medio limón.

Y obviamente a todos esos silleteros que me ayudaron a entender mejor su historia y su tradición, gracias por su disposición, gracias por permitirme entrar en sus vidas y aprender un poco de ellas.

Septiembre 28 de 2015. 


\section{Referencias}

Alcaldía de Medellín. (2004). Plan de desarrollo Medellín compromiso de toda la ciudadanía 2004-2007. Recuperado de https://www.medellin.gov.co/iri/go/km/docs/pccdesign/SubportaldelCiudadano 2/PlandeDesarrollo 0 o 0 /Shared\%20Content/pdf\%20codigo\%20buen $\% 20$ comienzo/Texto\%20Completo\%20Acuerdo\%20Plan.pdf

Alcaldía de Medellín. (2008). Plan de desarrollo Medellín es solidaria y competitiva 2008-2011.

Recuperado

de https://www.medellin.gov.co/iri/go/km/docs/wpccontent/Sites/Subportal\%20de \%20Ciudadano/Plan\%20de\%20Desarrollo/Secciones/Publicaciones/Docume ntos/Gaceta\%200ficial\%20Plan\%20de\%20Desarrollo.pdf

Alcaldía de Medellín. (2012). Plan de desarrollo Medellín un hogar para la vida 2012-2015.

Recuperado de https://www.medellin.gov.co/iri/go/km/docs/wpccontent/Sites/Subportal\%20de \%20Ciudadano/Plan\%20de\%20Desarrollo/Secciones/Publicaciones/Docume ntos/PlaDesarrollo2012-2015/2012-04-

30 Proyecto\%20de\%20acuerdo\%20VERSION\%20COMPLETA.pdf

Álvarez, C. (2010, 6 de agosto). Teleantioquia sí se enlazará con Telemedellín. El Mundo. Recuperado de http://www.elmundo.com/portal/resultados/detalles/?idx=155980\&anterior=1\& paramdsdia $=5 \&$ paramdsmes $=06 \&$ paramdsanio $=\&$ cantidad $=25 \&$ pag $=1285 \# . V$ geLwPI_Okp

Álzate, G. (2014) Apuntes históricos sobre el origen del tráfico internacional de drogas ilícitas en Medellín. Pensar Historia, 4, 47-59.

Appelbaum, N. (2007). Dos plazas y una nación: raza y colonización en Riosucio, Caldas 1846-1948. Bogotá: Instituto Colombiano de Antropología e Historia (ICANH), Universidad de los Andes, Colegio Mayor Nuestra Señora del Rosario.

Arango Gaviria, L. G. (1991). Mujer, religión e industria: Fabricato 1923-1982. Medellín: Universidad de Antioquia.

Arango Mejía, G. (1992). Genealogías de Antioquia y Caldas (2ª . Ed.). Medellín: Imprenta Departamental.

Arcila, M. T. (1986). Apuntes sobre identidad cultural: el caso antioqueño. Boletín de Antropología, 20 (6), 101-110 
Arcila, M (1994). Creadores de riqueza: cultura e imágenes culturales en Antioquia. Boletín de Antropología, 24 (8), 95-118.

Arenales, R. (2015, 10 de abril). Corrupción en el Metro de Medellín. Semanario Voz. Recuperado de http://www.semanariovoz.com/2015/04/10/corrupcionen-el-metro-de-medellin/

Ashoka. (2014, 27 de junio). The transformation of Medellín, and the surprising company behind it. Forbes Recuperado de http://www.forbes.com/sites/ashoka/2014/01/27/the-transformation-ofmedellin-and-the-surprising-company-behind-it/

Associated Press. (2014, 12 de diciembre). Light displays help Medellín outshine its dark past. The Dallas Morning News. Recuperado de http://www.dallasnews.com/lifestyles/travel/international/20141212-lightdisplays-help-medellin-outshine-its-dark-past.ece

Baker, C. (2014, diciembre). Famous for Flowers. Yes, Flowers. National Geographic. Recuperado de http://travel.nationalgeographic.com/travel/besttrips-2015/\#/explora-parque-medellin-colombia $85220600 \times 450 . j p g$

Bargent, J. (2013, 8 de octubre). Colombia: The virgin auctions in Pablo Escobar's home town. The Indepent. Recuperado de http://www.independent.co.uk/news/world/americas/colombia-the-virginauctions-in-pablo-escobar-s-home-town-8867289.html

Bolívar Rojas, E. (1991). El desfile de silleteros. Medellín: Departamento de Fomento y Turismo.

Bolívar Rojas, E. (2001). El desfile de silleteros: fiesta y drama en una celebración urbana. Nueva Revista Colombianas del Folclor, 21 (7), 19-32.

Bonuccelli, D. (2009, 27 de octubre). Medellín's cultural renaissance. Lonely Planet. Recuperado de http://www.lonelyplanet.com/colombia/northwestcolombia/medellin/travel-tips-and-articles/12947

Botero, L. V. (2013, 11 de agosto). La belleza que supo hacerse esperar. El Colombiano. Recuperado de http://www.elcolombiano.com/belleza que supo hacerse esperarDCEC 255143

Calonge Cole, S. (2006). La representación mediática: teoría y método. Psicologia da Educação, 23, 75-102.

Caparrós, Martín (2009, 12 de agosto). El peso de la tradición. Semana. Recuperado de 
http://www.elespectador.com/impreso/opinion/articuloimpreso155880-elpeso-de-tradicion

Carman, M. (2006). Usos y abusos de la cultura en Buenos Aires. Colección Monografías, 18, 1-53.

Carrasquilla, T. (1992). Antología de cuentos. Medellín: Comfenalco.

Casa de Nariño (2004). Silleteros y Feria de las Flores, nuevo patrimonio cultural de Colombia. Comunicado de prensa Presidencia de la República de Colombia. Recuperado de http://historico.presidencia.gov.co/prensa new/sne/2004/marzo/19/16192004. $\underline{\mathrm{htm}}$

Castro Cardenas, L. (2011, 6 de agosto). El Desfile de Silleteros es un carnaval. El Colombiano. Recuperado de http://www.elcolombiano.com/el desfile de silleteros es un carnavalEAEC 144660

Congreso de Colombia (2003) Ley 838. Diario oficial 45325. Recuperado de http://www.secretariasenado.gov.co/senado/basedoc/ley 0838 2003.html

Congreso de Colombia (2008) Ley 1185 de 2008 por la cual se modifica y adiciona la Ley 397 de 1997 -Ley General de Cultura-y se dictan otras disposiciones. Diario Oficial 46929. Recuperado de http://www.icanh.gov.co/nuestra entidad/normatividad/leyes/ley 11852008 modifica ley 3971997

Da Silva, L. (2008). Memorias en conflicto. De memorias denegadas, subterráneas $y$ dominantes. Buenos Aires: Mimeo.

Diago Valencia, G. (1974, 16 de agosto). Desfile multicolor y autentico. El Tiempo. Última B.

Duncan, G. (2013). Una lectura política de Pablo Escobar. Co-herencia, 10 (19), 235-262.

Duzán, M. J. (2009, 6 de junio). ¿Qué pasa en Medallo? Semana. Recuperado de http://www.semana.com/opinion/articulo/que-pasa-medallo/103868-3

Echeverri, L. M., Rosker, E., \& Restrepo, M.L. (2010). Los orígenes de la marca país Colombia es pasión. Estudios y Perspectivas en Turismo, 19 (3), 409421.

Escobar, J. C. (2004). Las élites intelectuales en Euroamérica Imaginarios identitarios, hombres de letras, de artes y de ciencias en Medellín y Antioquia, 1830-1920. Co-herencia, 1 (1), 126-149. 
Escobar, J. C. (2009). Progresar y civilizar: imaginarios de identidad y élites intelectuales de Antioquia en Euroamérica, 1830-1920. Medellín: Fondo Editorial Universidad EAFIT.

Especial Antioquia 200 años. (2013, 12 de agosto). El Tiempo. P. 13.

Farnsworth Alvear, A. (2000). Dulcinea in the factory: myths, morals, men, and women in Colombia's industrial experiment, 1905-1960. Londres: Duke University Press.

Franco, S. (2012). Mortalidad por homicidio en Medellín, 1980-2007. Ciência \& Saúde Coletiva, 17 (12), 3209 - 3218.

Galdos, G. (2014, 28 de septiembre). Virgins for sale in Colombia in world's biggest brothel. 4 News. Recuperado de http://www.channel4.com/news/colombia-medellin-prostitution-virgins-gangspablo-escobar

Gerald, M. (2012). Medellín: tragedia y resurrección. Mafia, ciudad y estado. Bogotá: Planeta.

Giraldo, J. (2008). Seguridad en Medellín: el éxito, sus explicaciones, limitaciones y fragilidades. Estados Unidos: Wilson Center.

Giraldo Ramírez, J. (2015, 11 de enero). Menos violencia en Medellín. El Colombiano. Recuperado de http://www.elcolombiano.com/menos-violenciaen-medellin-AY1076156

Gobernación de Antioquia. (2007). Desfile de silleteros: 50 años. Medellín: Fundación Viztaz.

Gómez Salazar, B. (2008). Procesos de transformación de la ciudad de Medellín descentramientos-aglomeración-polarización 2000-2007. En Brand, P. (Director), Escuela de Planeación Urbano-Regional. Simposio llevado a cabo en el VII Seminario Nacional de Investigación Urbano Regional, Universidad Nacional de Colombia, Medellín.

Harpaz, B. J. (2014, 13 de diciembre). Colombia sheds Escobar-era image. The Columbus Dispatch. Recuperado de http://www.dispatch.com/content/stories/travel/2014/12/14/1-colombia-shedsescobar-era-image.html

Hernández, S. (2012, 28 de noviembre). El tour de Pablo Escobar. Soho. Recuperado de http://www.soho.com.co/zona-cronica/articulo/el-tour-depablo-escobar/28806 
Hill, K. (2014, 30 de agosto). Colombian revisited. The Australian. Recuperado de http://www.theaustralian.com.au/travel/colombia-revisited/story-e6frg8rf$\underline{1227040477366}$

Hernández Osorio, C. (2013, 8 de agosto) La tradición se comparte en Santa Elena. El Colombiano. Recuperado de http://www.elcolombiano.com/la tradicion se comparte en santa elenaMCEC 254697

Hobsbawm, E., \& Ranger, T. (2002). La invención de la tradición. Barcelona: Critica.

Hoyos, J. J. (1984, 11 de agosto). De las flores ya no se puede vivir. El Tiempo. P. $10 \mathrm{C}$.

Humanes, M.L. (2003). La reconstrucción del pasado en las noticias. La representación mediática del 24 aniversario de la muerte de Franco y la coronación de Juan Carlos I. Análisis, 30, 39-57.

Humboldt, A. (1800). Alexander Bon Humboldt en Colombia. Extractos de sus diarios. Recuperado de http://www.comunidadandina.org/bda/docs/CO-CA0004.pdf

Jaramillo Salazar, P., \& Grupo de Investigación Territorialidades. (2004). El País (aje) de los Paisas: lo regional más allá de la Región. En B. Nates Cruz, \& F. Villota Galeano (Comp.), La desgeneralización del mundo. Reflexiones sobre procesos de globalización. Manizales: Universidad de Caldas.

Jiménez Ruíz, M. M. (2014, 2 de agosto). Silleteros de Medellín llevan tatuada en la piel la tradición. El Tiempo. Recuperado de http://www.eltiempo.com/colombia/medellin/feria-de-flores-en-medellin-2014silleteros-de-santa-elena-/14332884

Lemoine, M. (2013, 12 de junio). La verdad sobre la Operación Orión. Las 2 Orillas. Recuperado de http://www.las2orillas.co/la-verdad-sobre-laoperacion-orion/

Lewin, J. E. (2013, 3 de abril). Las preguntas del arzobispo que le aguan la fiesta a Medellín (y sus respuestas). La Silla Vacía. Recuperado de http://lasillavacia.com/historia/las-preguntas-del-arzobispo-que-le-aguan-lafiesta-medellin-y-sus-respuestas-41752

López, L. (1910). La raza antioquena: breves consideraciones sobre su psicologia, desenvolvimiento, y educación. Medellín: Imprenta de la Organización.

López Ramírez, R. S. (2013). Santa Elena y el desfile de silleteros ¿una relación eterna? Universidad de Antioquia. 
Martínez, R. (2014, 15 de abril) Caos de habitantes de calle volvió a la avenida de Greiff. El Colombiano. Recuperado de http://www.elcolombiano.com/historico/caos de habitantes de calle volvio a la avenida de greiff-PXEC 290807

López, Odilia. (1857, 2 de mayo). Eterna primavera. El Colombiano. P. 13.

Medellín cómo vamos. (2014). Informe de calidad de vida de Medellín, 2013. Recuperado de: http://www.medellincomovamos.org/informe-de-calidad-devida-de-medell-n-2013

Mejía Arango, J. L. (2008, 7 de agosto). El arte efímero de las silletas. El Tiempo. Recuperado de http://www.eltiempo.com/archivo/documento/MAM-3044989

Mejía Restrepo, B. (2013). Modelo de gestión de seguridad ciudadana en el marco de "Medellín del miedo a la esperanza" años 2004-2007. INCAE Business School.

Melguizo, J. H. (2008, 7 de agosto). Medellín, capital de la vida. El Tiempo. Recuperado de http://www.eltiempo.com/archivo/documento/MAM-3044982

Montoya, J., Cuesta, O., Flecha, O., Viadé, D. (2011). Moravia como ejemplo de transformación de áreas urbanas degradadas: tecnologías apropiadas para la restauración integral de cuencas hidrográficas. Nova, 09 (15), 41-52.

Morales, E. (2014, 18 de abril) Volvieron los gamines a Medellín. La Silla Vacía. Recuperado de http://www.las2orillas.co/volvieron-los-gamines-a-medellin/

Namur, P. (2013, 30 de agosto). Transformación social de Medellín: la clave de la ciudad más innovadora del orbe. El Pulso. Recuperado de http://www.pulso.cl/noticia/economia/economia/2013/08/7-28907-9-

transformacion-social-de-medellin-la-clave-de-la-ciudad-mas-innovadora-delorbe.shtml

Nates Cruz, B. (2009). Pensar el mundo, practicar el entorno. Etnografías y reflexiones desde una antropología de las territorialidades. Revista de dialectología y tradiciones populares, 64 (1), 267-269.

Nora, P. (1993). Entre memoria e história. A problemática dos lugares. Proyecto histórico, 10, 122-131.

Nulvallue. (1995, 28 de marzo) Investigarán obras de metro de Medellín. El Tiempo. Recuperado de http://www.eltiempo.com/archivo/documento/MAM$\underline{283888}$

Oficina de las Naciones Unidas contra la Droga y el Delito, \& Alcaldía de Medellín (2013). Estudio Exploratorio Descriptivo de la dinámica delictiva del tráfico de estupefacientes, la trata de personas y la explotación sexual comercial 
asociada a viajes y turismo en el municipio de Medellín. Recuperado de https://www.unodc.org/documents/colombia/2013/Noviembre/UNODC Medell in.pdf

Opinión. (2006, 6 de agosto). Los silleteros. El Colombiano. P. 2 A.

Opinión. (2014, 11 de agosto). El Silletero. El Colombiano. P. 23 Cartas a la directora.

Orozco, N. (2013, 25 de septiembre). Medellín no es como la pintan. Las 2 Orillas. Recuperado de http://www.las2orillas.co/medellin-es-como-la-pintan/

Ortiz, M. I. (2014, 28 de diciembre) La lucha de los silleteros porque los consideren patrimonio. De la Urbe Digital. Recuperado de http://delaurbe.udea.edu.co/2014/11/30/la-lucha-de-los-silleteros-porque-losconsideren-patrimonio/

Peláez, Marta (2012). ¿Cuál es la Antioquia que pasa cuando el silletero pasa? Un estudio sobre las transformaciones del desfile de silleteros de Medellín. Universidad de Antioquia, Medellín, Colombia.

Quintero Calle, D. (2014). Una propuesta de marca para Medellín basada en los casos Barcelona y Córdoba. Universidad de Medellín.

Quintero Restrepo, M. (2010, 7 de agosto). Silletas con toda la tradición. El Colombiano. Recuperado de http://www.elcolombiano.com/silletas con toda la tradicion-JVEC 99707

Quintero Restrepo, M. (2010, 8 de agosto). Los primeros pasos fueron de emoción. El Colombiano. Recuperado de http://www.elcolombiano.com/los primeros pasos fueron de emocionPVEC 99879

Redacción. (2007, 13 de agosto). Antioquia entera se extasió con los silleteros. El Colombiano. P. 2D.

Redacción. (2012, 10 de febrero). ¿Una segunda 'Donbernabilidad'?: las dos versiones sobre la tregua de las bandas en Medellín. La Silla Vacía. Recuperado de http://lasillavacia.com/historia/6706

Redacción. (2014, 25 de marzo). La desmovilización ficticia del Caciqué Nutibara según "el Alemán". Verdad Abierta. Recuperado de http://www.verdadabierta.com/justicia-y-paz/versiones/371-el-aleman-freddyrendon-herrera/3087-la-desmovilizacion-ficticia-del-cacique-nutibara-segunel-aleman 
Redacción Américas. (2014, 7 de junio). Medellín's comeback. The trouble with miracles. The Economist. Recuperado de http://www.economist.com/news/americas/21603432-transformationcolombias-second-city-will-be-hard-copy-trouble-miracles

Redacción elcolombiano.com. (2013, 1 de marzo). Arzobispo de Medellín cuestiona situación actual de la ciudad. El Colombiano. Recuperado de http://www.elcolombiano.com/arzobispo de medellin cuestiona situacion a ctual de la ciudad-KEEC 231281

Redacción diarioadn.co Medellín. (2014, 31 de julio) ¿Cómo fue la primera versión de la Feria de las Flores? Medellín. Adn. Recuperado de http://diarioadn.co/medellin/mi-ciudad/feria-de-las-flores-2014-historia-deldesfile-de-silleteros-1.118880

Redacción elespectador.com (2014, 17 de abril). Tras el Foro Urbano, reaparecen habitantes de calle en Medellín. El Espectador. Recuperado de http://www.elespectador.com/noticias/nacional/tras-el-foro-urbanoreaparecen-habitantes-de-calle-mede-articulo-487480

Redacción Medellín. (1983). Dos generaciones de campesinos recorren las calles de Medellín. El Tiempo. P. 10 C.

Redacción Medellín. (2010, 30 de noviembre). Se lanza marca ciudad de Medellín. Dinero. Recuperado de http://www.dinero.com/actualidad/noticias/articulo/se-lanza-marca-ciudad$\underline{\text { medellin/108744 }}$

Redacción Medellín. (2013, 11 de agosto). Los silleteros son toda una tradición. El Tiempo. P. 11 regional.

Redacción Medellín. (2014, 18 de septiembre). Medellín rechaza artículo en el que se decía que ciudad es un burdel. El Tiempo. Recuperado de http://www.eltiempo.com/colombia/medellin/alcaldia-protesta-por-articulo-quedice-que-medellin-es-un-burdel/14553835

Redacción Nación. (1996, 23 de diciembre). Mauss y el metro de Medellín. Semana. Recuperado de http://www.semana.com/nacion/articulo/mauss-elmetro-de-medellin/31181-3

Restrepo, J. D. (2014, 4 de noviembre). ¿A qué costo se transformó Medellín? Semana. Recuperado de http://www.semana.com/opinion/articulo/a-que-costo-setransformo-medellin-por-juan-diego-restrepo/383403-3

Rivera, D. (2011, 8 de agosto). La gloria se la llevo este año una flor de flores. El Colombiano. P. 15 A. 
Rodríguez Díaz, R., \& Mena Montes, N. (2008). Opinión pública y frames: la crisis de los Cayucos. Revista Latina de Comunicación Social, 63, 341-347.

Saldarriaga, J. (2008, 6 de agosto). Óscar no sudará más con el 05 . El Colombiano.

Recuperado

de http://www.elcolombiano.com/oscar no sudara mas con el 05-NLEC 8953

Saldarriaga, J. (2014, 9 de agosto). En 1807 hubo un desfile de silletas. El Colombiano. Recuperado de http://www.elcolombiano.com/en 1807 hubo un desfile de silletasIGEC 306086

Shankarman, S. (2013, 23 de mayo) Why turning Medellín into the Silicon Valley of South America is great for tourism. Skift. Recuperado de http://skift.com/2013/05/23/medellin-turning-into-the-silicon-valley-of-southamerica-is-great-for-tourism/\#/

Spitaletta, R. (2009, 2 de marzo). Se calentó el parche. El Espectador. Recuperado de http://www.elespectador.com/columna123262-se-calento-elparche

Superintendencia de Industria y Comercio (2011) Resolución N. 21789. Recuperada de http://www.silleteros.com/csse/index.php?option=com content\&view=article\&i $\underline{d=120 \& \text { Itemid }=108}$

Todorov, T. (1995). Los abusos de la memoria. Barcelona: Paidós Asterisco.

Torres Gómez, J. C. (2014, 6 de octubre). Las dos caras de Medellín. Las 2 Orillas. Recuperado de http://www.las2orillas.co/las-dos-caras-de-medellin/

Twinam, A. (1982). Miners, Merchants, and Farmers in Colonial Colombia. Austin: University of Texas.

Uribe, R. (1942). Panorama antioqueño. El pueblo antioqueño. Universidad de Antioquia.

Vélez, L. (2013, 10 de agosto). Acento patrio y 3300 personas. El Colombiano. P. 26 Tendencias.

Villa, Catalina. (1994, 7 de agosto). Marcha floral, indiscriptible. El Colombiano. P. 12 A.

Wade, P. (1987). Raza y ciudad: los chocoanos en Medellín. RAED: Revista Antioqueña de Economía y Desarrollo (Medellín), (23), 35-46. 
Wade, P. (1997). Gente negra, nación mestiza: dinámica de las identidades raciales en Colombia. Bogotá: Universidad de Antioquia.

Williams, R. (1980). Marxismo y literatura. Barcelona: Península.

Zuluaga, Margarita. Silleteros despidieron la Feria. El Tiempo. 8 de agosto de 2005. 1-10.

\section{Páginas web}

http://www.medellin.gov.co/

www.medellin.travel

http://www.colombia.co/

http://www.medellinconventionbureau.com/

http://www.secretariasenado.gov.co

http://silleteros.blogspot.com/

http://www.floresdelsilletero.com/

http://uli.org

http://rutanmedellin.org/

\section{Videos}

Carvajal, J. S. (2013, agosto 11). Todas las flores fueron para Antioquia. [Archivo de video]. Recuperado de http://www.elcolombiano.com/mauricio londono londono ganador absoluto del desfile de silleteros-ECEC 255089

L. [lauraiveth130584]. (marzo 27). Colombia el riesgo es que te quieras quedar. [Archivo de video]. Recuperado de https://www.youtube.com/watch?v=xZepZ8cJOuU

Myjunglebox. [myjunglebox]. (2011, junio 29). Feria de las Flores 2011. [Archivo de video]. Recuperado de https://www.youtube.com/watch?v=aj7TMN6ufvo

Medellín Convention Bureau. [Canal de BureaudeMedellin]. (2012, enero 5). Marketing de Ciudad, una potente herramienta de promoción y captación de eventos. [Archivo de video]. Recuperado de https://www.youtube.com/watch?v=yDxSxiGktR0 
Medellín Convention Bureau. [Canal de BureauMedellin]. (2012, enero 13). Microprograma ferias. [Archivo de video]. Recuperado de https://www. youtube.com/watch?v=uGo8hvVIWil

Medellín Travel. [Medellín Travel] (2014, mayo 6). Conoce la tradición de los silleteros de Medellín. [Archivo de video]. Recuperado de https://www.youtube.com/watch?v=vAY18rQkCTM\&list=PLbSoL9xO1qMqwID2ZE2Xx_T7M1RUKJo6

Presidencia de la República de Colombia. [Presidencia de la República de Colombia]. (2013, abril 23). Colombia realismo mágico. [Archivo de video]. Recuperado de https://www.youtube.com/watch?v=0njQwjb3GaE

Redacción elcolombiano.com (2014, 10 de agosto). Pujanza, verraquera y orgullo antioqueño en el Desfile de Silleteros. [Archivo de video]. Recuperado de http://www.elcolombiano.com/desfile-silleteros-feria-de-las-flores-

$100820143724187164001-J G E C \quad 306168$

Velandia, G. [Gustavo Velandia]. (2007, abril 15). Colombia es Pasión. [Archivo de vídeo]. Recuperado de https://www.youtube.com/watch?v=HyFXo_WLJVI

Zambrano, A. [Alexis Zambrano]. (2009, mayo 4). Colombia el riesgo es que te quieras quedar. [Archivo de video]. Recuperado de https://www.youtube.com/watch?v=3pmEtrTn7Bc

Zapata, W. [Wilton Zapata Sandoval]. (2014, diciembre 21). Ven a Medellín, el lugar donde comienza lo inolvidable. [Archivo de video]. Recuperado de https://www.youtube.com/watch?v=iYXBPA46bxl 